Biography, Gender and History:

Nordic Perspectives 


\section{BIOGRAPHY, GENDER AND HISTORY: NORDIC PERSPECTIVES}

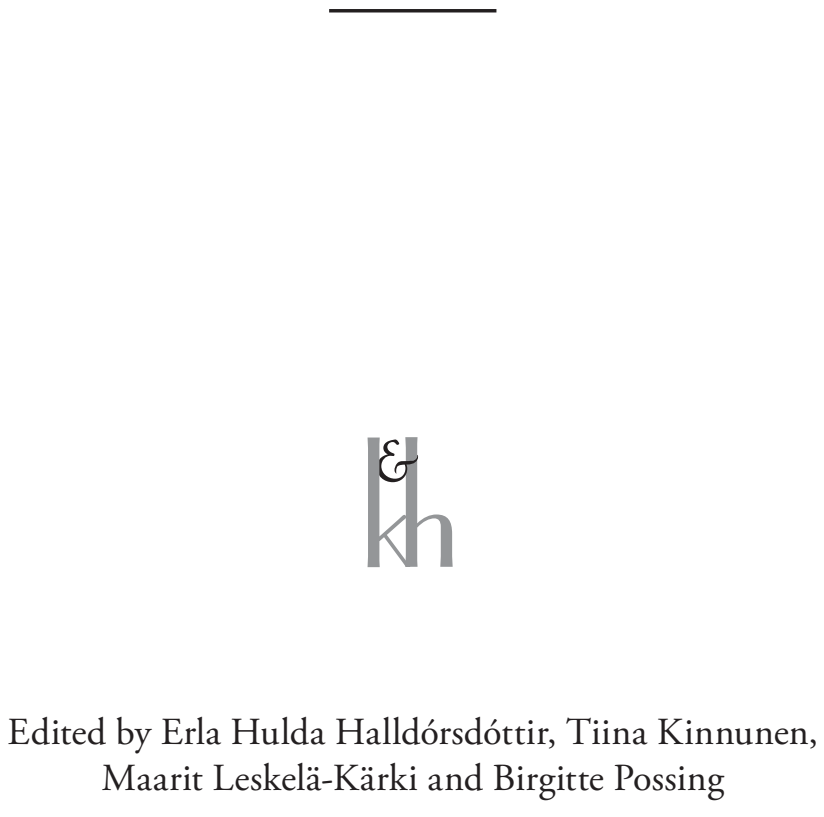

Maarit Leskelä-Kärki and Birgitte Possing 


\section{CULTURAL HISTORY — KULTTUURIHISTORIA 14}

Published by k\&h, kulttuurihistoria, Turun yliopisto, Turku, Finland ISBN 978-951-29-6677-6 (PRINT)

ISBN 978-951-29-6678-3 (PDF)

ISSN 1458-1949

Cultural History

20014 University of Turku

http://www.culturalhistory.net

(C) 2016 Authors

Cover Henri Terho \& Kimi Kärki

Cover photo Anna-Maija Nisula, Varrella virran (detail), 2008

Layout Kimi Kärki

Printed in Painosalama, Turku, Finland 2016

VERTAISARVIOITU

KOLLEGIALT GRANSKAD

PEER-REVIEWED

www.tsv.fi/tunnus 


\title{
CONTENTS
}

\author{
ERLA HULDA HALLDÓRSDÓTTIR, TIINA KINNUNEN, \\ MAARIT LESKELÄ-KÄRKI \\ Doing biography
}

\section{GENRE}

\section{BIRGITTE POSSING}

How does one relate a complex life? Reflections on a polyphonic portrait of the minister and intellectual Bodil Koch (1903-1973)

CHRISTINA CARLSSON WETTERBERG

Biography as a way of challenging gender stereotypes:

Reflections on writing about the Swedish author and feminist

Frida Stéenhoff (1865-1945)

\section{GENDER}

\section{ERLA HULDA HALLDÓRSDÓTTIR}

A biography of her own: The historical narrative and Sigríður Pálsdóttir (1809-1871)

\section{ANTTI HARMAINEN}

Group biography as an approach to studying manhood and religion in late nineteenth-century Finland

KRISTINE KJÆRSGAARD

Love and emotions in the diplomatic world: The relationship between

Bodil Begtrup's public and private lives, 1937-1956 


\section{CONTEXT}

\section{TIINA KINNUNEN}

'Fighting Sisters': A comparative biography of Ellen Key (1849-1926)

and Alexandra Gripenberg (1857-1913) in the contested field of

European feminisms

IRENE ANDERSSON

Telling stories of gendered space and place: The political agency of

the Swedish Communist Valborg Svensson (1903-1983)

\section{RELATIONS}

\section{MAARIT LESKELÄ-KÄRKI}

Remembering mother: Relations and memory in the biographical project on Minna Krohn (1841-1917)

HEINI HAKOSALO

Coming together: Early Finnish medical women and the multiple levels of historical biography

KAISA VEHKALAHTI

Bad girl biographies: Child welfare documents as gendered biographies

TIINA KINNUNEN, MAARIT LESKELÄ-KÄRKI, ERLA HULDA HALLDÓRSDÓTTIR, BIRGITTE POSSING

Afterword: Future challenges

Authors

Index 


\section{Doing biography}

\section{Erla Hulda Halldórsdóttir, Tiina Kinnunen, Maarit Leskelä-Kärki}

Biografering är det svar vi ger den andre och oss själva på frågan vad en människa är. ${ }^{1}$

Since the turn of the twenty-first century historians, alongside with literary scholars and social scientists, have developed a renewed interest in researching the individual, a development which is commonly referred to as the biographical turn. Historical biography is an old practice with a strong but often debated relationship with history as an academic discipline. In the twentieth century, in particular after the Second World War, academic historians generally did not see biography as 'real' history or perceive it as an appropriate field of historical research. As a result, biography remained under-theorised, even marginalised until recent years. ${ }^{2}$

The recent turn has been influenced by several overlapping currents, scholarly and political, associated with the idea of the interdependence between the individual and historical change. Reflecting the growing

1 [Doing biography is the way to explore the question of what it means to be human.] Larsson 2001, 428.

2 Österberg 1996; Ambjörnsson et al. 1997; Margadant 2000; Hamilton 2009; Caine 2010; Possing 2012; Possing 2015. 
interest in ordinary people's lives, biographical writing and research has become entangled with the multidisciplinary field of life-writing research and its methodological interest in using various autobiographical sources. As a result, historical biography is part of an interdisciplinary field that is characterised by individuals' own ways of documenting and memorialising their lives and giving meaning to their experiences. This interest in the individual has strongly been influenced by a number of political and social changes at the end of the twentieth century such as the end of the Cold War, which brought with it a revision of history in Europe as well as an upsurge of the autobiographical. ${ }^{3}$ The biographical turn is best exemplified by the thriving publication of books and articles with biographical themes. ${ }^{4}$

The Nordic countries are no exception in this turn. As a result, a number of studies 5 and historical biographies have been published in recent years, many of them innovative in their use of theoretical and methodological perspectives, particularly concerning the lives of women. ${ }^{6}$ As part of this on-going endeavour, this anthology reflects upon how biography has been discussed, debated and theorised in the Nordic contexts during the past two to three decades and aims at further developing this field, especially from the perspective of women's and gender history. We acknowledge that the biographical turn has influenced also other disciplines, but focus on historical biography and its relationship with historical scholarship. Furthermore, biography and biographical

3 Knudsen and Gram-Skjoldager 2012.

4 For discussion concerning academic history and biography, as well as the historiography of biography, see e.g. Lee 2009; Hamilton 2009; Caine 2010; Suominen-Kokkonen 2013; Burdiel and Foster 2015; Possing 2015; Renders et. al. 2016. See also various recent thematic issues in academic journals, e.g.: The American Historical Review 2009; Journal of Interdisciplinary History 2010; Historiallinen Aikakauskirja 2012.

5 See e.g. Ambjörnson et al. 1997; Egeland 2000; Rosengren and Östling 2007; Historiallinen Aikakauskirja 2012; Hakosalo et. al. 2014.

6 On biographies on women see e.g. Sulkunen 1989, 1995, 1999; Possing 1992, 2001, 2007; Haavet 1998; Ollila 1998; Ulvros 2001; Kristmundsdóttir 2001; Leskelä-Kärki 2006; Niskanen 2007; Florin, Niskanen 2010; Carlsson Wetterberg 2010; Pálsdóttir 2010; Vainio-Korhonen 2010 and 2012; Hirdman 2012. 
research has been prominent at national and Nordic conferences since the late twentieth century. This anthology is a result of a lively exchange between scholars from the Nordic countries, developed at various conferences and in different networks. ${ }^{7}$

Notwithstanding its Nordic perspective this anthology is essentially international. Nordic biography is strongly conversant with international scholarship on biography, as will become evident in the individual chapters. This volume is a contribution to the growing international interest in, and theorisation of, biography and biographical research as a method of doing history. Its first objective is to strengthen the relationship between history and biography by demonstrating the various ways of employing biography as a method of historical analysis, in particular from a gender perspective. Its second objective is to shed light on the Nordic contribution to this methodological development.

By paying attention to certain methodological challenges and discussions, this volume examines what the biographical turn means in the Nordic countries. Salient here is the concept of gender and the issues that gender history raises in biographical research, most notably the intersection of the public and private domains of lives. Furthermore, the chapters discuss the ways the source material we use influences the reconstruction of lives. Connected to this, the relation between the individual protagonist and his/her contemporary historical context is a focal issue. The chapters will show the advantages of biographical research, with its careful contextualization and focus on the particular and the local. The book also points out the ethical challenges inherent in biographical research, particularly concerning the relationship between the researcher and the protagonist.

This anthology consists of ten chapters by scholars from various Nordic countries with the focus on the above-mentioned challenges:

7 Haavet 2009, 110-123; Manns and Sundevall 2014; Blazevic 2014. This volume has its origins in the networking that has happened e.g. in the Nordic Women's and Gender History conferences particularly in Turku (2005) Reykjavik (2008), Bergen (2012), and Stockholm (2015). Biographical research has also been a topic at the Nordic History conferences, for instance in Tampere in 1996. 
gender, context, and relationality. The individual chapters each have their own particular case through which they analyse the methodologies of doing historical biography. The volume has a coherent Nordic perspective, since each of the chapters has been developed in crossnational dialogue with the other authors. As the editors of the volume, we do not claim that there is a specific Nordic way of writing biography; however, the Nordic countries do have interrelated history and cultural heritage, and have often been perceived as a distinct entity, both by the countries themselves and by the outside world. ${ }^{8}$ All the cases discussed in the chapters emerge from Nordic history and thus share a somewhat similar context. We argue that a Nordic perspective helps us to approach the common western narratives from the point of view of more remote parts of Europe. ${ }^{9}$ At the same time, we want to emphasise the signifigance of transnational influences and connection.

Biography can be seen as the meeting point for many of the questions posed by historians today, as Giovanni Levi and Nigel Hamilton have put it. Biographical research, as well as other forms of research using and interpreting autobiographical sources, raises important questions concerning such problematic concepts as experience, agency, context and identity formation. ${ }^{10}$ The renewed interest in biography is strongly

8 The shared history of the countries originates from the Middle Ages, when Finland became part of the Swedish Kingdom, and Denmark and Norway shared a common history for centuries. In the early nineteenth century when Finland was separated from Sweden and became autonomous part of Russia, Norway and Sweden formed a personal union that lasted until 1905. Iceland, for its part, was under Norwegian and Danish rule from the thirteenth century until 1944. During the twentieth century, particularly in the post-Second World War period, the Nordic welfare model has characterised the societal development in this area. As far as academic historiography itself is concerned, the shared history goes back to the early twentieth century when historians from the Nordic countries launched the tradition of Nordic historical conferences in Lund 1905. See more in Gustafsson et al. 2007.

9 For a recent discussion on the Western feminist history and its applicability to the stories and experiences of the more marginal or remote areas, see for example Koobak and Marling 2014, who criticise the use of Western feminist theories in the contexts of the former countries in the Eastern block. More generally, see Abrams 2008. See also Hemmings 2005.

${ }^{10}$ Levi 2010; Hamilton 2009. 
related to and intersects with microhistory, gender history, history of everyday life and "history from below", all of which question the grand narratives of history and emphasise the individual, in particular ordinary people and their experiences in society. ${ }^{11}$

As in traditional biography, personal documents still comprise the core of biographers' source material, but the understanding and usage of these documents as sources has changed during the last decades. Letters, diaries, memoirs and other autobiographical sources are no longer considered unproblematic or as giving unmediated access to individual lives in the past. Under the influence of interdisciplinary perspectives and new theoretical fields like life-writing studies as well as postmodern historiography, the complexity of these sources is now acknowledged and taken into account, as shown for instance in Birgitte Possing's biography on the nineteenth-century pioneer of women's education in Denmark Viljens Styrke. Natalie Zable. En Biografi (1992). In this book, which was one of the trailblazers of the biographical turn in Scandinavia, Possing explored new ways of using autobiographical sources in historical biography. ${ }^{12}$

After her book on Zahle, Possing further developed her ideas on the relation between biography and history. In her chapter in this volume, 'How does one relate a complex life? Reflections on a polyphonic portrait of the minister and intellectual Bodil Koch (1903-1973)', Possing reflects upon the analytical tools she used when she wrote her biography of Danish minister and intellectual Bodil Koch (1903-1972) and compares this enterprise with her previous book. Possing not only wanted to make Koch, a popular and well known politician in the mid twentieth century, visible but also wanted to challenge the traditional life and times biography by focusing on a particular (public) phase of

${ }^{11}$ On microhistory and its influence on history, see e.g. Magnússon and Szijártó 2013. See also recent Nordic works where individuals and their life stories play a central role in literacy studies (Kuismin and Driscoll 2013; Edlund, Edlund and Haugen 2014; Edlund, Ashplant and Kuismin 2016). On the "new history from below" and the individual see e.g. Lyons 2014, $14-29$.

12 Possing 1992; Klein 2009, 311. See e.g. Stanley 2004; Leskelä-Kärki, Lahtinen and Vainio-Korhonen 2011; Edlund, Edlund and Haugen 2014. 
Koch's life. Furthermore, there were paradoxical views and narratives concerning the political life of Koch which Possing set out to analyse and understand. In her chapter, Possing discusses the challenges she met and the ways she solved them. Eventually, she ended up creating a polyphonic biography, and in her chapter she emphasises that there is never one pure voice that the biographer can find and use to depict the 'true' story of an individual.

In contrast to Possing, and thus reflecting the versatility of biography's methodology, Christina Carlsson Wetterberg shows how also a more traditional chronological approach can help the biographer to produce an innovative life narrative. In her chapter 'Biography as a way of challenging gender stereotypes: Reflections on writing about the Swedish author and feminist Frida Stéenhoff (1865-1945)', she argues that writing about nineteenth- and early twentieth-century feminist protagonists from a gender-sensitive and feminist perspective can result in a narrative of victimhood. To challenge male-female boundaries and to open up the intersections of their life spheres, and thus produce a versatile picture of both the temporal context and the protagonist, she suggests that one has to work as close to the sources as possible and without prejudice.

\section{The biographical turn in the Nordic historiographies}

The biographical turn is by no means a simple or transparent concept. Finnish historian and biographer Irma Sulkunen, for instance, considers historical biography to be part of an ongoing process, implying that the concept of a turn is too dramatic. ${ }^{13}$ In a recent, inspiring editorial for the European Journal for Women's Studies, Kathy Davis critically ponders upon the concept of a "turn" and its meaning especially for feminist studies. She argues that we need to be careful when promoting turns, as 'they are exercises in power, enabling some knowledge to be excluded'.

${ }^{13}$ Irma Sulkunen discussed critically the concept of biographical turn at Historiantutkimuksen päivät in Helsinki 2012. Her point is referred in Hakosalo, Jalagin, Junila and Kurvinen 2012, 375. 
Identifying something as a "turn" necessitates making a critical distinction between what is important and what is not. It creates borders and constraints between scholars as well. Thus it is relevant to consider what we mean by the biographical turn and how this idea relates to the previous assumptions within historical research about writing biographies and life-stories. We agree with Davis in that 'we need to be sensitive to all attempts, including our own, to authorise one discourse, one theoretical perspective, or one disciplinary approach, while excluding, silencing or dismissing others.' ${ }^{14}$

In her book Ind i Biografien (2015), which explores theoretical and methodological aspects of historical biography, Birgitte Possing also emphasises the long tradition of biography and argues that at different times biographers repeatedly ask the same basic questions in their biographies. However, che claims, what is new-and what makes the concept of a turn justified - is the multitude of questions and answers, different interpretations and methodologies that are presently being introduced. Thus, the turn has much to do with us, the historians and biographers, and the ways we perceive biography and think about our research. It is us, the historical biographers, who are rethinking the biographical field in the light of the cornucopia of new biographies, new knowledge, new narrative and experimental forms, and the entrance of hitherto unknown protagonists. ${ }^{15}$

It is exactly this recent and emerging trend in biography and new biographical research that is emphasised in this volume. The chapters revolve around issues that have been central to biographical research for centuries, but now they are increasingly explored from theoretical, methodological and ethical perspectives. Underlining the many-sided nature of biography, we argue that biography 'cannot be dealt with in the singular ${ }^{16}$. Complexity, diversity and multivocality are the perspectives from which this volume contributes to the ongoing discussion on biography.

\footnotetext{
${ }^{14}$ Davis 2015, 125-128.

15 Possing 2015, 29-34, 188-199.

16 Possing 2015.
} 
A prominent feature in the biographical turn has been the concept of "new biography" which, under postmodern influences, emphasises fragmented selves, identity formation and gendered performances. ${ }^{17}$ However, when discussing the genre of biography, and the development of biographical writing, we have to be aware that both have, to a great degree, been developed on the margins of academic historiography and in the overlapping field of academic and non-academic writing. In Finland, Sweden and Denmark, we can trace long historical roots for men and women writing biographies outside academia, nonetheless the significantly influencing the field. ${ }^{18}$ Indeed, many of the topics being discussed now were pointed out already by earlier biographers, for instance the concept of "new biography" was discussed by biographers and thinkers such as Virginia Woolf already in the 1920s. ${ }^{19}$

As the historiography of biography clearly demonstrates, biography as an academic enterprise, as history, has been characterised by continuities and ruptures, as well as by differences between countries. The historian Michael Jonas has analysed the present state of Nordic biography from a German perspective and argues that the historical biography was not highly esteemed in Denmark and Norway after the Second World War, and even less so in Sweden. ${ }^{20}$ In contrast, historical academic biography never lost its prestige in Finland.

The status of historical biography in Denmark and Sweden changed radically in the 1990s. This is evident in the anthology Att skriva människan (1997), in which the editors demonstrate that it had been impossible to present a biography as a doctoral thesis in the discipline of history in Sweden in the 1960s and 1970s. The heavy debate in Denmark in the 1990s changed that. This turnabout took place around the time of Birgitte Possing's aforementioned doctoral thesis on the gendered history of education in Denmark and its pioneer Natalie Zahle. It paved

\footnotetext{
${ }^{17}$ Margadant 2000; Possing 2015.

18 See e.g. Katainen, Kinnunen, Packalén and Tuomaala 2005; Kinnunen 2013; Leskelä-Kärki 2014.

${ }^{19}$ Woolf 1967. See also Caine 2010; Possing 2015, 31. Concerning the discussion on the renewal of biography in Finland in the 1920s and 1930s, see Jalava 2013, 297-298. See also Puntila (1936) 2005.

${ }^{20}$ Jonas 2009.
} 
the way to a new appreciation of the dynamic relationship between the individual personality's work, life and time, that is, between the individual protagonist and the contemporary national and international historical context, as opposed to focusing on the primacy of structures in historical analysis. ${ }^{21}$

Due to language barriers, the cases of Iceland and Finland have been less well known within the Nordic region than those of Sweden, Norway and Denmark, and even less so in the wider western context. Historical biography has long been a popular genre in Iceland, but it has been surprisingly sparsely discussed as a historical method or enterprise until recent years. Historical biography was, for the most part, the life and work -biography of important or well-known men, often written by trained historians, ${ }^{22}$ either within or outside the academia. ${ }^{23}$

During the 1970s, younger Icelandic historians (many influenced by the Marxist theory) rejected biography as an outdated form of doing history. Influenced by structuralist ideologies, they preferred to find and analyse 'long processes, economic systems, administrative systems and all kinds of welfare systems'. ${ }^{24}$ Indeed, biography was in a need of a renovation in Iceland as the historian Björn Porsteinsson pointed out in 1974. As an opponent for a doctoral thesis on a historical biography, he criticised historical biography for being a stagnated form of narrative, an account of life and work, instead of analytical research. ${ }^{25}$ Although historians continued to criticise biography for its tendency to be hagiographic in style, it was not until the 1990s that biography began

${ }^{21}$ The interesting debate around Possing's work (which, due to language, is though mainly Swedish and Norwegian) is documented and analysed in her book, Ind i Biografien (translated in English in 2016 as Understanding Biographies). Possing 2015, 15-19. See also Ambjörnsson, Ringby and Åkerman 1997, 7-8.

${ }^{22}$ Until the 1960s, history within the University of Iceland was taught as a part of 'Icelandic Studies', which was a mixture of literary studies, Icelandic linguistics and history, with heavy emphasis on the medieval period.

${ }^{23}$ Several of these biographies were written as dissertations for a university degree.

${ }^{24}$ Karlsson 2011, 10-12; Halldórsdóttir 2013.

${ }^{25}$ Porsteinsson 1974. 
to change in Iceland. ${ }^{26}$ The strong male bias, both in terms of biographers and protagonists, was however still persistent and, as Erla Hulda Halldórsdóttir shows in her chapter, women as historical biographers and as worthy protagonists only entered the stage during the late 1990s. Historical biography and biographical studies are gradually becoming stronger as an academic field and method in Iceland.

As pointed out, Finland differs to some extent from the general Nordic pattern. Already in 1990, the historian Ari Uino underlined the importance of biographical research as part of historiography. In the 1980s, and without interruption into the 1990s, historical biographies were written by historians at different stages of their academic careers and the value of these studies was never seriously called into question because of the genre. In addition, doctoral theses employing a biographical approach were commonly presented, even if some doubts were expressed as to whether they could be accepted as problem-based research. Such criticism was countered, for instance, with the argument that in a biography the individual life was the problem to be examined. ${ }^{27}$

In retrospect, some serious biases in the Finnish biographical scholarship are visible, one such being associated with gender. Despite the emerging field of women's history in the 1980s, the biographical field was still strongly male biased, both in terms of authors and protagonists, with a heavy emphasis on political historical biographies. This changed in the subsequent decades. As a result, similar to the case in other national historiographies, in Finland integrating women and gender into biographical research has gradually reshaped the field both in terms of methodology and in terms of the visibility of a new group of historical actors. Biographical research, in turn, has influenced women's and gender history; it helps both in questioning the grand narratives of history and in deconstructing the canonised interpretations of women's history. This can be noticed particularly in the works of Finnish historians Irma Sulkunen and Anne Ollila, both of whom interwove

\footnotetext{
${ }^{26}$ Magnússon 2004; Halldórsdóttir 2013. See also short articles in the historical journal Saga XLIX:2 (2011), 9-52, where eleven scholars and biographers, from different disciplines answer the question 'What is biography' ['Hvað er ævisaga?'].

27 Saarikoski (1989) 2006.
} 
microhistory, gender history and biographical analysis into narratives of individual women in times of social change. ${ }^{28}$

However, bridging the gap between history and biography has not been without tensions among women's and gender historians themselves. The Dutch historian Mineke Bosch, among others, points out many women's and gender historians' ambivalence concerning biography. ${ }^{29}$ This ambivalence has also been evident among Nordic women's and gender historians, who have primarily worked in the field of social history and emphasised the role of women in the workforce and in social movements. ${ }^{30}$

\section{Gendering biographies}

Gender plays a central role in this book and permeates all the chapters, as they reflect topical and innovative research into male and female lives, and aim at developing a gender-sensitive historical biography in which gender is analysed and discussed in different historical contexts. Like any other social and cultural phenomenon, gender is constructed in time, in historical processes. Historians can offer a perspective that is open and sensitive to the diversity of the past as well as for the ruptures and disconnections between the past and the present.

As the gender historian Jeanne Boydston has argued, the perspective of gender as a category of analysis has in a way led us to a situation where we tend to see the past and its situations as similar to the present. In our eagerness to defend gender as a historical process, we have embraced the similarities while overlooking the differences. We

${ }^{28}$ Sulkunen 1989, 1995, 1999; Ollila 1997.

${ }^{29}$ Bosch 2012. See also e.g. Caine 1994, 250; Schaser 2001, 143.

${ }^{30}$ See the special volume of Scandia 'Genushistoriens utmaningar' (2/2012) concerning the content and status of gender history in present Sweden. In her article, Ann-Catrin Östman pays attention to how the status of biographical and life-historical approaches has been higher in Finland than in Sweden, particularly in the 1990s. Östman 2012, 95. See also Tuomaala 2005. 
should be equally sensitive to differences other than gender as well as to the complexity, inconsistency and discrepancy of the past. ${ }^{31}$ Here, in particular, biography can help us in developing more subtle interpretations, since biography is always local and particular. Individual lives can 'illustrate how differences of wealth and power, of class and gender and of ethnicity and religion have affected historical experiences and understanding', like Australian historian and biographer Barbara Caine has put it. ${ }^{32}$ And in looking from the periphery of the North - a term, whose meaning differs historically and geographically - we are aware of, and underscore, the importance of remembering that history is always culturally and socially situated in time and space.

Despite the impact of women's and gender history on biographical research, in the beginning of the second millennium women are still in the minority as protagonists (and also among writers). In her aforementioned book, Ind i biografien, Birgitte Possing reveals interesting figures on the gender imbalance in historical biography, both concerning protagonists and biographers, which still characterises the field. She analysed biographies published and reviewed from 2000-2011 in six selected historical journals and shows that the biographical genre was not only male dominated - it was astonishingly male dominated. Although the number of female protagonists rose from 10 per cent to 15 per cent in the United States, the United Kingdom, Germany, France, Sweden, Norway and Denmark, and more women were therefore being given their due place in history, men still filled on average 85 per cent of the biographical picture. There were large differences between countries however: in the United States, Sweden and Denmark the proportion

${ }^{31}$ Boydston 2008, 558-583. See also Aalto, Kaartinen, Konola, Lahtinen, Leskelä-Kärki and Tuohela, 2014. Boydston refers to Joan Scott's influential analysis on gender as an analytical category, see Scott, 1988. See also Antti Harmainen's chapter in this anthology. Further on gender history from national and international perspectives see e.g. Morgan 2006; Abrams 2006; Downs 2010. On Nordic discussion see e.g. Hagemann 2003; Possing 2014.

${ }^{32}$ Caine 2010, 10. See also e.g. Florin 2015. 
of women protagonists reached 20 per cent, i.e. one-fifth of all biographies. ${ }^{33}$

This bias draws attention to and is the part of the western historiographical tradition in which women have until recently not been considered active agents in history and thus have not been given a place in national or international historiography. Although this tradition has been challenged for nearly fifty years, women's and gender history is still underrepresented in most canonised historical narratives. The demand, and need, for a change and for revised histories is best reflected in the flourishing publication of national and international (European) books addressing the theme of gendered history. ${ }^{34}$

Biographies seem to be a fruitful way of exploring and representing women's lives - and thus to gradually change the way women are perceived and written about as historical agents in historical narratives. However the issue of female protagonist is related not only to gender, but also to differences within the category of women. In her chapter 'A biography of her own: The historical narrative and Sigríður Pálsdóttir (1809-1871)', Erla Hulda Halldórsdóttir argues that ordinary lives are still marginal as the protagonists of women's biographies, and indeed their lives, lack a frame of narration within the field. She maintains that even though feminist biographers and theorists stress the importance of exploring and writing the lives of ordinary and forgotten women rather than exceptions and trailblazers, these women seldom become biographical subjects on the strength of their own individual lives but rather serve as representatives of larger groups of women. Halldórsdóttir grounds her argument on her study on the life and letters of the Icelandic Sigríður Pálsdóttir (1809-1871) who wrote her brother 250 letters during her lifetime but otherwise did nothing that would make her a woman worthy of a biography.

${ }^{33}$ Possing 2015, 65

${ }^{34}$ Blom and Sogner 2006; Smith 2000, 2010; Porciani and O'Dowd 2004; Abrams, Gordon, Simonton and Yeo 2006; Epple and Schaser 2006; Hagemann and Quataert 2007; Downs 2010. 
Most of the chapters in this volume are concerned with women, which is indicative of the present situation in the field of "new biographies". ${ }^{35}$ These have mostly been devoted to exploring women's lives, their circumstances and the meaning of gender for women. The increasing interest in biographical research among women's and gender historians in the early 2000s has resulted in a growing number of biographies of women as entrepreneurs, scientists, scholars, politicians, social reformers, artists, feminists for instance. Many of these biographies have been influenced by postmodern views and are experimental in form and context. In the Nordic context, this is exemplified for instance by Kirsti Niskanen's book on the Swedish economist Karin Kock, Karriär i männens värld (2007), and Birgitte Possing's aforementioned book on the Danish minister and theologian Bodil Koch, Uden Omsvøb (2007).

Altough the history of masculinities and manhood is a growing field within gender history, men continue to be the unproblematised main characters of most biographies. ${ }^{36}$ In this anthology the male sex and gendered ideas about men and masculinity are analysed by Antti Harmainen in his chapter 'Group biography as an approach to studying manhood and religion in late nineteenth-century Finland'. For his analysis, the use of private sources is of crucial importance because they open up a possibility to see how the rigid binary of femininity and masculinity was challenged within particular circles in Finnish society. Harmainen discusses the emergence of a specific form of modern masculinity that saw features like empathy, which were normally perceived of as feminine, as combatible with a morally sustainable modern manhood. This concept of manhood was constructed in relation to alternative forms of religious beliefs, in this case theosophy and spiritualism. Here, Harmainen's analysis is in line with Christina Carlsson Wetterberg's, who sees the potential of biography in challenging the idea of strictly gendered spaces and identities.

Harmainen's analysis reflects how one of the characteristics of gendered biographies is the emphasis on the overlapping of the private and

\footnotetext{
35 We follow the argument of Birgitte Possing (2015) on how we need to talk about biography in plural, biographies, due to the diversity of the genre.

${ }^{36}$ See e.g. Possing 2012; Hakosalo, Jalagin, Junila and Kurvinen 2014, 14.
} 
public spheres in an individual's life. ${ }^{37}$ The contested binary of public and private spheres has been one of the most salient concepts of women's and gender history since the early 1970s and continues to motivate research on how women have dealt with the ideology of separate spheres while simultaneously trying to shape their new-found public lives. Kristine Kjærsgaard also addresses the public and the private in her chapter 'Love and emotions in the diplomatic world: The relationship between Bodil Begtrup's public and private lives, 1937-1956' which investigates the complex love relationship, and later marriage, between Bergtrup and her fellow diplomat, Laurits Bolt-Jørgensen, as well as the way Bergtrup's public life and career as a diplomat was affected by her relationship with Bolt-Jørgensen despite her determination to keep public and private separated. Kjaersgaard demonstrates that it is impossible to separate the private from the public in biographical study as they are always intertwined, even if it is the public life which is being investigated.

\section{Contextualising the individual(s) in biographies}

For a historian writing historical biography, the most challenging task is the representation relationship between the individual and his/her historical period. Virginia Woolf pointed out this difficulty when she was contemplating the process of writing her memoir in the late 1930s: 'I see myself as a fish in a stream; deflected; held in place; but cannot describe the stream.' Later, the British biographer Hermione Lee argued that the biographer's task is to see both the fish and the stream, that is, the context or "spirit of the age" in which one lives. ${ }^{38}$

In her Biography and History (2010) Barbara Caine argues that the upsurge of interest in biography among historians derives from their growing insight into the compatibility of the individual and the social/

${ }^{37}$ Ware 2010.

${ }^{38}$ Lee 2009, 13-14. See also how Finnish cultural historian Jukka Sarjala discusses the limitations of contextualisation in outlining too tightly the possible worlds of an individual in the past, Sarjala 2014. 
political: "The "turn" that they describe involves a new preoccupation with individual lives and stories as a way of understanding both contemporary societies and the whole process of a social and historical change. ${ }^{39}$ Women's and gender historians have contributed to the discussion about the dynamic relationship between the context and the individual(s) with their emphasis on gendered and gendering structures and historical processes, as evidenced by the pioneering work of scholars such as Birgitte Possing and Susanne Malchau in Denmark, Inger Elisabeth Haavet in Norway, Yvonne Hirdman in Sweden, and Irma Sulkunen and Anne Ollila in Finland. ${ }^{40}$ The relationship between the individual and the context is an underlying theme that this anthology seeks to develop further.

As mentioned above, microhistory, like biography, has broadly influenced the paradigm changes in historical scholarship during the past few decades, especially with respect to the usage of personal documents such as letters or diaries, which are also vital sources for biographers. The link between biographical and microhistorical research can be seen as mutually enriching, but also as problematic. On the one hand, there is an overlap between these two, as for instance Barbara Caine points out. ${ }^{41}$ On the other hand, there are methodological and theoretical differences between these two fields of research. ${ }^{42}$ Microhistorians have generally chosen their protagonist because of his/her often marginal or exceptional life - criminal activity being one of the popular themes. Such individuals have been used to mirror their society and its hegemonic beliefs; "normal exceptions" is the preferred concept because the "abnormal", unsuitable or punishable behaviour of these protagonists discloses what is thought to be normal. These individuals are thus not necessarily chosen because of their own merits but are, rather, explored as representatives of bigger processes or groups.

Notwithstanding biography's special interest in the individual life, a good historical biography always develops our understanding of histori-

${ }^{39}$ Caine 2010, 1.

40 Possing 1992, 2007; Malchau 1998; Haavet 1998; Hirdman 2006, 2012; Sulkunen 1989, 1995, 1997; Ollila 1998.

${ }^{41}$ Caine 2010, 111-116.

${ }^{42}$ Lepore 2001; Caine 2010; Magnússon and Szijártó 2013. 
cal structures and processes. This is evident for example in the Swedish historian Yvonne Hirdman's fascinating biography about her mother, Den röda grevinnan. En europeisk historia (2012). The starting point for this book are the turbulent interwar years in Europe which Hirdman wanted to illuminate. In the end, the book became first and foremost a biography of her mother, Charlotte Hirdman, who led independent and cosmopolitan life in Germany, Moscow and Copenhagen before settling in Sweden as a housewife and mother of three. The political changes in Europe are made visible through the life story of a woman who remained a mystery to her own daughter. ${ }^{43}$

The American historian Jill Lepore has illuminated the differences between microhistorical and biographical research regarding their relation to individuals. Whereas microhistory aims at saying something about the culture in which an individual is positioned, the focus of a biographer is always on the individual, despite the careful contextualization. In microhistory, the aim is to analyse some mystery or phenomena, whereas in biography a life story has value in its own right. The individual is thus more of a tool for the microhistorian, who, as a consequence, does not develop as strong an attachment or 'fall in love' with her protagonist as biographers usually do - regardless of whether this is a bad thing or not. ${ }^{44}$

Notwithstanding the differences between them, Irma Sulkunen's research demonstrates the productive overlap between microhistorical and biographical approaches and how this overlap opens up new possibilities to analyse historical change. In her trilogy $(1989,1995,1999)$ on three Finnish women, Sulkunen uses their individual lives to explore large societal and political processes, such as nation building, formation of civil society and the modern gender order. In doing so, she conceptualises biography not as a separate field of historical research but rather as a method. She actually employs the concept of "person-based history" (in Finnish henkilöhistoria) to underline her view of the mutual relationship between biography and history. In 2009, Sulkunen retrospectively describes one of her protagonists as follows: 'Through the activities

${ }^{43}$ Hirdman 2012.

${ }^{44}$ Lepore 2001. 
of Miina Sillanpää, Finland's perhaps most notable female politician, the book traces in particular the changes that took place in the social system of gender when paid employment became more common and class society more firmly established. ${ }^{45}$ However, in her book on Mandi Granfelt (1995), a school teacher and nationalist activist, Sulkunen does point out the importance of uniqueness when she stresses that, although Mandi could be seen as an example of her times, she nevertheless remains 'undefinably unique' in character. ${ }^{46}$

In Tiina Kinnunen's chapter "Fighting Sisters": A comparative biography of Ellen Key (1849-1926) and Alexandra Gripenberg (1857-1913) in the contested field of European feminisms', Kinnunen employs comparative biographical approach in analysing the ideological controversy between two contemporaries, the Finnish Gripenberg and the Swedish Key. Combining a biographical with a microhistorical approach, Kinnunen's analysis, influenced by the work of Irma Sulkunen, sheds light on nineteenth- and early twentieth-century feminism as a contested field, nationally and transnationally. The controversy surrounding the two feminists fighting for their ideas - and each other - is analysed against the broader context of modernization of gender relations and the changing role of religion.

Women's political agency is also analysed in Irene Andersson's chapter 'Telling stories of gendered place and space: The political agency of the Swedish Communist Valborg Svensson (1903-1983)'. Andersson shows how the unique life of a unique person, Valborg Svensson, turns into multiple lives when analysed through sources that are disparate yet still interconnected. In the sources available to Andersson, Svensson was mostly depicted by others or the sources were produced for identity production in public arenas. From her fragmented sources, Andersson creates a context and a narrative of gendered and class-related space for political agency in pre- and post-Second World War Sweden.

\footnotetext{
${ }^{45}$ Sulkunen 2009.

${ }^{46}$ Sulkunen 1995, 9. ['jäljittelemättömän ainutkertainen']
} 


\section{Biographical relationships}

Writing a biography is always a relational process and, as such, biography seems to be a special genre. Biography hinges on the interaction between the narrator and the individuals $s^{47}$ being narrated, though the latter might be long deceased. This makes biography a dialogical process in which the narrator constantly mirrors her/himself and her/his opinions in relation to the other, and changes her/his opinions not only about the person being narrated but also about her/himself. As biographers, we must always clarify on what our relationship is to the individual(s) we narrate, since this relationship and reflection define what kind of biography we write. Thus, writing a biography means always balancing between involvement and detachment, as Hermione Lee puts it. ${ }^{48}$

Biographers and historians dealing with individual lives have often found it difficult to find this balance. Some have found a way to address the issue by publishing what the literary scholar Rachel Morley calls 'pre-biographical' writings, that is, scholarly articles that ponder upon the dilemmas and challenges they are facing while studying their protagonist and writing her/his story. ${ }^{49}$ Although there are several scholars at the present writing about the question of who can interpret and represent a life, and how, or who 'owns' the remembrance of an individual, we have to keep in mind that there have been writers pondering upon these questions also earlier. For example, the Finnish writer, translator and biographer Tyyni Tuulio used many of the practices, that historians have started to use later on, already in the 1950s and 1960s, when she wrote several biographies of women. Her biographies and various essays concerning biographical writing were exceptional, since she used many

${ }^{47}$ In this section the focus is on biographies with one protagonist. However, it has to be kept in mind that a growing number of biographies are written about several protagonists. See e.g. Heini Hakosalo's chapter in this volume.

${ }^{48}$ Lee 2009. About this relational process, see also e.g. Culley and Styler 2011; Morley 2012; Leskelä-Kärki 2012, 2015.

${ }^{49}$ Morley 2012, 77-95. Indeed, there are several such articles to be found in historical and scholarly journals, also by the editors of this volume: see e.g. Leskelä-Kärki 2001, 2004; Halldórsdóttir 2010, 2015. Also, for instance, Kristmundsdóttir 2006; Holmes 2005; Lee 2008. 
of the means historians promote today: self-reflection, highlighting the importance of private sources, dialogical relation with the past persons, positioning of herself, and playing with literary genres. ${ }^{50}$

The British sociologist Liz Stanley has addressed relationality widely in her works, and she emphasises acknowledging the importance of what happens in 'the spaces between lives lived and lives written' - a process, a relationality that eventually leads to a final outcome: a book, a biography, or an article. The process of producing should be, she argues, an acknowledged part of the final outcome. ${ }^{51}$ Stanley has discussed the unclear borders between autobiographical and biographical writing in her classic book The auto/biographical I (1992). In it, she rejects the rigid differentiation between biography and autobiography and argues for their reciprocity by introducing the concept auto/biography. Stanley argues that "doing biography" in any of its sub-forms is intimately connected with the biographer's own autobiography.' ${ }^{52}$

In other words, we ourselves, our origins, experience and views are reflected, consciously and unconsciously, in our works and we must admit this. The historian Kate Brown phrases it aptly when she writes that we (or historical and biographical writing) must acknowledge that 'nearly all good history writing relies on the experience of the historian, the historian's own biography, to grasp and represent the past'. ${ }^{53}$ To acknowledge one's own voice as a biographer and the intimate dialogue one creates with the biographée is not common in the Nordic research. In the third biography of her trilogy, Irma Sulkunen, however, dares to take this step when she engages in a dialogue with an eighteenth-century woman who is said to have started a religious revivalist movement, but of whom there are no extant sources. ${ }^{54}$

In her chapter 'Remembering mother: Relations and memory in the biographical project on Minna Krohn (1841-1917)', Maarit Les-

\footnotetext{
${ }^{50}$ See more in Leskelä-Kärki 2013. See also Oittinen 2005, 186.

${ }^{51}$ Stanley 2002.

52 Stanley 1992, 162-163.

53 Brown 2009, 599. See also e.g. Leskelä-Kärki 2006, 78-85, 631-639, where she discusses the emotional relation of a researcher towards her subjects and develops a methodology of empathetic and hermeneutic approach further.

${ }^{54}$ Sulkunen 1999.
} 
kelä-Kärki discusses relationality as an important starting point when engaging with the life of another, but also as an ethical issue that rises between the biographer and her subject. In her biographical project on Finnish nineteenth-century school teacher Minna Krohn, LeskeläKärki questions the idea of a coherent life story and asks how we could approach past persons in a way that would allow many voices and contradictions. Analysing the different narrated memories of Minna Krohn, and implementing the ideas of relational identity theorised by Adriana Cavarero, she asks how we, as biographers, might make use of the varied and often also contradictious material produced on past persons and do ethically solid biographical studies.

The multiple interpretations of relationality are a topic we address in many of our chapters. It is a wide concept that impinges on only the relationship between the biographer and her/his biographée but also the awareness of the relationality of (our) identities. Several of the chapters deal with the protagonist's close relationships - with children, spouses and friends, as well as with larger circles of colleagues and networks. We argue that contextualising our protagonist not only entails exploring her/him in relation to relevant cultural, political or economic contexts but should also include analysis of the social surroundings and the relevant networks and relations.

The increasing popularity of group biography is an indication of the usefulness of this approach, as exemplified for instance by Susanne Malchau Dietz' book Køn, Kald og Kompetencer. Diakonissestiftelsens kvindefallesskab og omsorgsuddannelser 1853-1955 (2013) ${ }^{55}$ and Christina Florin's study on Swedish feminists' campaign for the vote, Kvinnor fär röst: kön, känslor och politisk kultur $i$ kvinnornas rösträttsrörelse (2006). In this volume, Heini Hakosalo points out, that, since the 1980s, most group biographies have been written by women about women. ${ }^{56}$ Most of these works focus on the ways gender and social, cultural and political structures limit or open up possibilities for their women protagonists. ${ }^{57}$

\footnotetext{
${ }^{55}$ For group biography, see e.g. Malchau Dietz 2013 and Caine 2010, 47-61.

${ }^{56}$ See Hakosalo 2014. See also e.g. Elqvist-Saltzman 1997.

57 Ware 2010.
} 
In this anthology, Antti Harmainen uses group biographical approach to historicise certain aspects of masculinity and men's lives. In her chapter 'Coming together: Early Finnish medical women and the multiple levels of historical biography', Heini Hakosalo asks how a biographer can combine various aspects of biographical approach when studying several individuals. She distinguishes between a set, a group and an individual approach and argues that the research question directs which of the approaches to employ and how they should be implemented. She suggests that group biography is best suited for an analysis of relations and their historicity, and for examining influences between individuals. She categorises pair biography, such as that used by Kristine Kjærsgaard in this volume, as a subcategory of group biography.

Hakosalo also discusses the multiple interpretations of the concept of collective biography. Kaisa Vehkalahti's chapter 'Bad girl biographies: Child welfare documents as gendered biographies' takes the idea of collective biography further, as she examines the biographical information collected and registered by the social service (child welfare) in Finland pertaining to 'delinquent' girls. As Vehkalahti demonstrates, this data is sensitive but at the same time also fascinating biographical source material. However, Vehkalahti does not focus on individual cases but instead examines knowledge-production, that is, the ways in which the forms and questions are structured, and what kind of biographies are produced. Simultaneously, she shows how these carefully structured (collective) biographies were used to define, interpret and identify improper behaviour.

The volume is concluded by an 'Afterword' that discusses four interrelated topics from the view point of the future of biography as a category of historical research. This chapter completes but also opens up new perspectives on the variety of viewpoints and approaches of the preceding individual chapters. These four topics are 'Biography as an interdisciplinary endeavor', 'Relationality and ethics: biographers, protagonists and readers', 'Biography and the transnational turn in history', and 'Biography as a tool to combine micro and macro'. The twelve chap- 
ters of this volume are aimed at showing the capacity of biography to reflect the challenges, both academic and political, of the constantly changing world and create tools to capture the interest of future reader generations.

\section{Bibliography}

Aalto, Ilana; Kaartinen, Marjo; Konola, Annikka; Lahtinen, Anu; Leskelä-Kärki, Maarit and Tuohela, Kirsi: Ajatuksia historiasta sukupuolentutkimuksen kentällä. Sukupuolentutkimus Genusforskning. 1/2014, 44-48.

Abrams, Lynn; Gordon, Eleanor; Simonton, Deborah and Yeo, Eileen Janes (eds.): Gender in Scottish History since 1700. Edinburgh University Press, Edinburgh 2006.

Abrams, Lynn: The Unseamed Picture: Conflicting Narratives of Women in the Modern European Past. Gender \& History. 20:3 (2008), 628-643.

The American Historical Review. AHR Roundtable. Historians and Biography. 114:3 (2009).

Ambjörnsson, Ronny; Ringby, Per and Åkerman, Sune: Inledning. Att skriva människan. Essäer om biografin som livshistoria och vetenskaplig genre. Eds. Ronny Ambjörnsson, Per Ringby and Suna Åkerman. Carlssons, Stockholm 1997.

Porsteinsson, Björn: Andmæli við doktorsvörn. Saga 12 (1974), 165-183.

Blazevic, Dunja: Jakten på et fagfelt: Den skandinaviske kvinne-og kønshistoriens fremvekst $i$ skaringsfletet mellom historieforskning og kvinne- og kjønsforskning. AIT, Bergen 2014.

Blom, Ida and Sogner Sølvi (eds.): Med kjønnsperspektiv på norsk historie. Fra vikingtid til 2000-årsskiftet. Second edition. Oslo, Cappelen akademisk forlag, 2006.

Bosch, Mineke: Well-Behaved Women Seldom Make History, But If They Do... - Reflections on Gender and Biography. Life Writing Matters in Europe. Ed. Marijke Huisman, Anneke Ribberink, Monica Soeting and Alfred Hornung. Universitätsverlag Winter, Heidelberg 2012, 223-240.

Boydston, Jeanne: Gender as a Question of Historical Analysis. Gender \& History. 20:3 (2008), $558-583$.

Brown, Kate: A Place in Biography for Oneself. AHR Roundtable. Historians and Biography. American Historical Review 114:3 (2009), 596-605.

Burdiel, Isabel; Foster, Roy (eds.): La historia biográfica en Europa. Nuevas perspectivas. Institutión Fernando el Católico de Zaragoza, Zaragoza 2015.

Caine, Barbara: Feminist Biography and Feminist History. Women's History Review. 2 (1994), 247-261.

Caine, Barbara: Biography and History. Palgrave Macmillan, London 2010.

Carlsson Wetterberg, Christina: 'Bara ett öfverskott af lif': en biografi om Frida Stéenhoff. Atlantis, Stockholm 2010.

Culley, Amy and Styler, Rebecca: Editorial: Lives in relation. Life Writing. 8:3 (2012), 237-240.

Davis, Kathy: The politics of the "turn”. European Journal of Women's Studies. 22:2 (2015), $125-128$.

Downs, Laura Lee: Writing gender history. Bloomsbury Academic, London 2010.

Edlund, Ann-Catrin; Edlund, Lars-Erik and Haugen, Susanne (eds.): Vernacular Literacies. Past, Present and Future. Northern Studies Monographs 3. Vardagligt skriftbruk 3. Umeå University and Royal Skyttean Society, Umeå 2014. 
Egeland, Marianne: Hvem bestemmer over livet? Biografien som litterer og historisk genre, Universitetsforlaget, Oslo 2000.

Florin Christina: Biografia rajoja rikkomassa. Kolme esimerkkiä ruotsalaisesta elämäkertatutkimuksesta. Historiallinen elämä. Biografia ja historiantutkimus. Eds. Heini Hakosalo, Seija Jalagin, Marianne Junila and Heidi Kurvinen. SKS, Helsinki 2014, 27-44.

Edlund, Ann-Catrine; Ashplant, T. G. and Kuismin, Anna (eds.): Reading and Writing from Below: Exploring the Margins of Modernity. Northern Studies Monographs 4. Vardagligt skriftbruk 4. Umeå University and the Royal Skyttean Society, Umeå 2016.

Elqvist-Saltzman Inga: Rostadslärarinnors livshistorier. Att skriva människan. Essäer om biografin som livshistoria och vetenskaplig genre. Eds. Ronny Ambjörnsson, Per Ringby and Sune Åkerman. Carlssons, Stockholm 1997, 123-144.

Epple, Angelika and Schaser, Angelika (eds.): Gendering Historiography. Beyond National Canons. Campus Verlag, Frankfurt 2006.

Florin, Christina and Kirsti Niskanen (eds): Föregångarna. Kvinnliga professorer om liv, makt och vetenskap. SNS Förlag, Stockholm 2010.

Gustafsson, Harald; Persson, Fredrik; Tornbjer, Charlotte; Wallette, Anna (eds.): Den dubbla blicken: historia i de nordiska sambällena kring sekelskiftet 1900. Sekel bokförlag, Stockholm 2007.

Haavet, Inger Elisabeth: Nina Grieg. Kunstner og Kunstnerhustru. Bergen 1998.

Haavet, Inger Elisabeth: Nyskapning og fellesskap - kjønnshistoriens historie sett gjennom de nordiske kvinnehistorikeremøtene. Tidsskrift for kjønnsforskning. 33:1-2 (2009), 110-123.

Hagemann, Gro: Feminisme og historieskrivning. Inntrykk fra en reise. Universitetsforlaget, Oslo 2003.

Hagemann, Karen and Quataert Jean H. (eds.): Gendering Modern German History: Rewriting Historiography. Berghahn Books, New York 2007.

Hakosalo, Heini; Jalagin Seija; Junila, Marianne and Kurvinen, Heidi: Yksilöiden vetovoima. Historiallinen aikakauskirja. 110:4 (2012), 375-377 .

Hakosalo, Heini; Jalagin, Seija; Junila, Marianne and Kurvinen, Heidi: Johdanto. Elämää suurempaa. Historiallinen elämä. Biografia ja historiantutkimus. Eds. Heini Hakosalo, Seija Jalagin, Marianne Junila and Heidi Kurvinen. SKS, Helsinki 2014.

Hakosalo, Heini; Jalagin, Seija; Junila, Marianne and Kurvinen, Heidi (eds.): Historiallinen elämä. Biografia ja historiantutkimus. SKS, Helsinki 2014.

Hakosalo, Heini: Tasohyppelyä. Varhaiset suomalaiset naislääkärit ja historiallisen biografian monimuotoisuus. Historiallinen elämä. Biografia ja historiantutkimus. Eds. Heini Hakosalo, Seija Jalagin, Marianne Junila and Heidi Kurvinen. SKS, Helsinki 2014, 45-61.

Halldórsdóttir, Erla Hulda: Baldvin's Tear. The Materiality of the Past. Making Sense, Crafting History. Practices of Producing Historical Meaning. Eds. Izabella Agardi, Berteke Waaldijk, Carla Salvaterra. Plus-Pisa University Press, Pisa 2010, 207-219.

Halldórsdóttir, Erla Hulda: Táknmynd eða einstaklingur? Kynjað sjónarhorn sögunnar og ævi Sigríðar Pálsdóttur. Skírnir. 187 (vor) 2013, 80-115.

Halldórsdóttir, Erla Hulda: Ferð til fortíðar \& sagnfræðingurinn í verki sínu. [A Journey to the Past \& the Historian in Her Work] Saga LIII:1 (2015), 121-139.

Hamilton, Nigel: Biography. A Brief History. Harvard University Press, Cambridge MA 2009.

Hirdman, Yvonne: Det tänkande hjärtat. Ordfront, Stockholm 2006.

Hirdman, Yvonne: Den röda grevinnan. En Europeisk historia. Ordfront, Stockholm 2012.

Historiallinen Aikakauskirja. Elämäkertatutkimus. 110:4 (2012).

Hemmings, Clare: Telling feminist stories. Feminist Theory 6 (2005), 115-139.

Holmes, Richard: Sidetracks: Explorations of a Romantic Biographer. Harper Collins publishers, London 2005. 
Jalava, Marja: Isien äänen äärellä. Paavo Virkkusen Agathon Meurman. Kirjoitettu kansakunta. Sukupuoli, uskonto ja kansallinen historia 1900-luvun alkupuolen suomalaisessa tietokirjallisuudessa. Eds. Marja Jalava, Tiina Kinnunen and Irma Sulkunen. SKS, Helsinki 2013, 269-306.

Jonas, Michael: Skandinavische Biographik. Handbuch Biographie. Methoden, Traditionen, Theorien. Ed. Christian Klein. Verlag J.B. Metzler. Stuttgart 2009, 307-312.

Journal of Interdisciplinary History. Biography and History: Inextricably Interwoven. Thematic issue. 40:3 (2010)

Katainen, Elina; Kinnunen Tiina; Packalén Eva ja Tuomaala Saara (eds.): Oma pöytä. Suomalaiset naiset historiankirjoittajina. SKS, Helsinki 2005.

Karlsson, Gunnar: Hvað er ævisaga? Saga XLIX:2 (2011), 10-12.

Kinnunen, Tiina: 'Mainioita naisia' - pienoiselämäkerrat autonomian ajan historiapolitiikkana. Historiallinen Aikakauskirja. 1 (2013), 390-400.

Klein, Christian (ed): Handbuch Biographie. Methoden, Traditionen, Theorien, Verlag J.B. Metzler. Stuttgart 2009.

Knudsen, Ann-Christina L., and Gram-Skjoldager, Karen (eds.): Living Political Biography. Narrating twentieth Century European Lives. Aarhus University Press, Aarhus 2012.

Kristmundsdóttir, Sigríłur Dúna: Far from the Trobriands? Biography as field. Locating the Field. Space, Place and Context in Anthropology. Berg, Oxford 2006, 163-177.

Kristmundsdóttir, Sigríður Dúna: Björg. Evisaga Bjargar C. Porláksson. JPV-forlag, Reykjavík 2001.

Kuismin, Anna and Driscoll, M.J. (eds.): White Field, Black Seeds. Nordic Literacy Practices in the Long Nineteenth Century. SKS, Helsinki 2013.

Larsson, Lisbeth: Sanning och konsekvens. Marika Stiernstedt, Ludvig Nordström och de biografiska berättelserna. Norstedts, Stockholm 2001.

Lee, Hermione: Biography: A very short introduction. Oxford University Press, Oxford 2009.

Leskelä-Kärki, Maarit: Kerrottu elämä. Naishistorioitsija ja toisen ihmisen historian kirjoittamisen ongelmia. Jokapäiväinen historia. Eds. Jorma Kalela and Ilari Lindroos. SKS, Helsinki 2001, 98-120.

Leskelä-Kärki, Maarit: Tutkija ja kolme sisarta. Polkuja henkilökohtaiseen historiantutkimukseen. Tutkija kertojana. Tutkimusprosessi, tunteet ja kirjoittaminen. Eds. Johanna Latvala, Eeva Peltonen and Tuija Saresma. Nykykulttuurin tutkimuskeskuksen julkaisuja 79. Jyväskylän yliopisto, Jyväskylä 2004, 306-340.

Leskelä-Kärki, Maarit: Kirjoittaen maailmassa. Krohnin sisaret ja kirjallinen elämä. SKS, Helsinki 2006.

Leskelä-Kärki, Maarit; Anu Lahtinen and Kirsi Vainio-Korhonen (eds.): Kirjeet ja historiantutkimus. SKS, Helsinki 2011.

Leskelä-Kärki, Maarit: Suhteellista elämää. Relationaalisuus ja biografinen vuorovaikutus. Historiallinen elämä. Biografia ja historiantutkimus. Eds. Seija Jalagin, Marianne Junila, Heini Hakosalo and Heidi Kurvinen. SKS, Helsinki 2014, 314-331.

Leskelä-Kärki, Maarit: Histories of women, histories of nation: Biographical writing as women's tradition in Finland, 1880s-1920s. Women telling nations. Eds. Amelia Santz, Francesca Scott and Suzan van Dijk. Rodopi publications, Amsterdam 2014, 311-334.

Leskelä-Kärki, Maarit: Cercanos y distantes. La relacionalidad en la investigación biográfica. La historia biográfica en Europa: Nuevas perspectivas. Eds. Isabel Burdiel and Roy Foster. Institución Fernando el Católico, Zaragoza 2015, 73-89.

Levi, Giovanni: Biography and microhistory. Opening paper for the session Biography and microhistory. Amsterdam 21st International Congress of Historical Sciences 2010. In electronic form at http://www.ichs2010.org/programme.asp 18.10.2010. 
Lyons, Martyn: A New History from Below? The Writing Culture of European Peasants, c. 1850-c. 1920. White Field, Black Seeds. Nordic Literacy Practices in the Long Nineteenth Century. Eds. Anna Kuismin and Driscoll, M. J. SKS, Helsinki 2013, 14-29.

Lyons, Martyn: The Writing Culture of Ordinary People in Europe, c. 1860-1920. Cambridge University Press, Cambridge 2014.

Magnússon, Sigurður Gylfi: Fortỉðardraumar: Sjálfsbókmenntir á Íslandi. Sýnisbók íslenskrar albýðumen-ningar, 9. Háskólaútgáfan, Reykjavík 2004.

Magnússon Sigurður Gylfi and István M. Szijártó: What is Microhistory? Theory and Practice. Routledge, London 2013.

Malchau, Susanne: Karlighed er tjeneste. Søster Benedicte Ramsing - En biografi. Dansk Sygeplejeråd 1998.

Malchau Dietz, Susanne: Kon, Kald og Kompetencer. Diakonissestiftelsens kvindefallesskab og omsorgsuddannelser 1853-1955. Nyt Nordisk Forlag, 2013.

Manns, Ulla and Sundevall, Fie (eds.): Methods, interventions and reflections. Report from the $X$ Nordic women's and gender conference, Bergen, Norway, August 9-12, 2012. Makadam förlag, Göteborg/Stockholm 2014.

Margadant, Jo Burr: The New Biography: Performing Femininity in Nineteenth-Century France. University of California Press, Berkeley 2000.

Morgan, Sue (ed.): Feminist History Reader. Routledge, London 2006.

Morley, Rachel: Fighting Feeling: Re-thinking Biographical Praxis. Life Writing. 9:1 (2012), 77-95.

Nasaw, David: Introduction. AHR Roundtable. Historians and Biography. The American Historical Review. 114:3 (2009), 573-578.

Niskanen, Kirsti: Karriär i männens värld. Nationalekonomen och feministen Karin Kock. SNS Förlag, Stockholm 2007.

Ollila, Anne: Jalo velvollisuus. Virkanaisena 1800-luvun lopun Suomessa. SKS, Helsinki 1998.

Pálsdóttir, Sigrún: Póra biskups og raunir islenskrar embattismannastéttar. JPV-útgáfa, Reykjavík 2010.

Porciani, Ilaria and O’Dowd, Mary: History Women. Storia della Storiografia. 46 (2004), 3-34.

Possing, Birgitte: Viljens Styrke. Natalie Zable. En biografi om køn, dannelse og magtfulldkommenhed, vol. 1-2. Gyldendal, Copenhagen 1992.

Possing, Birgitte: Zahle. Awaking the Promise of the Soul. Gyldendal, Copenhagen 2001.

Possing, Birgitte: Uden Omsvøb. Et portret af Bodil Koch. Gyldendal, Copenhagen 2007.

Possing, Birgitte: Portraiture and Re-portraiture of the Political Individual in Europe. Biography as a Genre and as a Deconstructive Technique. Living Political Biography. Narrating 20th Century European Lives. Eds. Ann-Christina Lauring Knudsen and Karen Gram-Skjoldager. Aarhus University Press, Aarhus 2012, 33-52.

Possing, Birgitte: The Historical Biography: Genre, History and Methodology. Writing Lives in Sport. Biographies, Life-histories and Method. Eds. John Bale, Mette K. Christiansen and Gertrud Pfister. Acta Jutlandica LXXVIII:3, Humanities Series 77, Aarhus University Press, Aarhus 2003, 17-25.

Possing, Birgitte: Representing Gendered Individualities: Reflections on the Biographical Turn. Methods, Interventions and Reflections. Report from the X Nordic Women's and Gender History Conference, Bergen, August 9-12 2012. Eds. Ulla Manns and Fie Sundevall. Makadam förlag, Göteborg/Stockholm 2014, 33-46.

Possing, Birgitte: The Biographer's Power and Private Archives. Crisis, credibility and corporate history. Ed. Alexander Bieri. ICA Studies, Liverpool University Press, Liverpool 2014, 53-63. 
Possing, Birgitte: At fortælle om mænd og kvinder som individer: Refleksioner over den biografiske vending i historien. Berättende - Liv-Mening. Eds. Gregers Andersson, Christian Carlsson Wetterberg, Carina Lidström and Steen Wistrand. Örebro Universitet, Örebro 2014, 19-35.

Possing, Birgitte: The Historical Biography. The International Encyclopedia of Social and Behavioral Sciences. Ed. James D. Wright. Second Edition. Elsevier, Oxford 2015, 644-649.

Possing, Birgitte: Ind i Biografien. Gyldendal, Copenhagen 2015.

Puntila, L. A.: Elämäkerta historiallisena tutkimuksena. Orig. Suomalainen Suomi 6/1936. Reprinted in Yksilö ja yhteisö. Henkilöhistoriallinen keskustelu Suomessa 1930-luvulta 2000-luvulle. Eds. Rami Kurth and Timo Soikkanen. Poliittisen historian laitoksen tutkimuksia 28, Turku 2006, 12-22.

Rem, Tore: Biografiens historie. Norsk Litterer Årbok. Oslo 2011, 106-131.

Renders, Hans; de Haan, Binne and Harmsma, Jonne (eds.): The Biographical Turn. Lives in history. Routledge, London 2016.

Rosengren, Henrik and Östling, Johan (eds.): Med livet som insats. Biografin som humanistisk genre. Sekel Bokförlag, Lund 2007.

Saarikoski, Vesa: Henkilöhistoriallisen tutkimuksen luonteen ja metodiikan ongelmia. Yksilö ja yhteisö. Henkilöhistoriallinen keskustelu Suomessa 1930-luvulta 2000-luvulle. Eds. Rami Kurth and Timo Soikkanen. Poliittinen historia, Turku 2006, 142-156.

Sarjala, Jukka: Päättymätön yksilö. Henkilöhistorian muuntuva kohde. Ennen ja Nyt 6/2014, electronic. http://www.ennenjanyt.net/2014/06/paattymaton-yksilo-henkilohistorianmuuntuva-kohde-2/

Schaser, Angelika: Bedeutende Männer und wahre Frauen. Biographien in der

Geschichtswissenschaft. Que-relles. Jahrbuch für Frauenforschung. 6 (2001), 137-152.

Scott, Joan W: Gender and the Politics of History. Columbia University Press, New York 1988.

Smith, Bonnie G.: The Gender of History. Men Women, and Historical Practice. Harvard University Press, Cambridge Mass. 2000.

Smith, Bonnie G.: Women's History: A Retrospective from the United States. Signs: Journal of Women in Culture and Society. 35 (2010), 723-47.

Stanley, Liz: Mourning becomes ...: The work of feminism in the spaces between lives lived and lives written. Women's International Forum. 25:1 (2002), 1-17.

Stanley, Liz: The auto/biographical I. The Theory and Practice of Feminist Auto/Biography. Manchester University Press, Manchester, [1992] 2002.

Stanley, Liz: The Epistolarium: On Theorizing Letters and Correspondences. Auto/Biography. 12 (2004), 201-235.

Sulkunen, Irma: Naisen kutsumus. Miina Sillanpää ja sukupuolten maailmojen erkaantuminen. Hanki ja jää, Helsinki 1989.

Sulkunen, Irma: Mandi Granfelt ja kutsumusten ristiriita. Hanki ja jää, Helsinki 1995.

Sulkunen, Irma: Liisa Eerikintytär ja hurmosliikkeet 1700-1800-luvulla. Hanki ja Jää/ Gaudeamus, Helsinki 1999.

Sulkunen, Irma: Biography, Gender and the Deconstruction of a National Canon. Gendering Historiography. Beyond National Canons. Eds. Angelika Epple and Angelika Schaser. Campus, Frankfurt/Main 2009, 65-77.

Suominen-Kokkonen, Renja (ed.): The Challenges of Biographical Research in Art History Today. Taidehistoriallisia tutkimuksia - Konsthistoriska studier 46. Taidehistorian seura Föreningen för konsthistoria, Helsinki 2013.

Ulvros, Eva-Helen: Sophie Elkan. Hennes liv och vänskapen med Selma Lagerlöf. Historiska media, Lund 2001.

Vainio-Korhonen, Kirsi: Sophie Creutz. Aateliselämää 1700-luvun Suomessa. SKS, Helsinki 2010. 
Vainio-Korhonen, Kirsi: Sofie Munsterhjelmin aika. Aatelisnaisia ja upseereita 1800-luvun Suomessa. SKS, Helsinki 2012.

Ware, Susan: Writing Women's Lives: One Historian's Perspective. Journal of Interdisciplinary History. 40:3 (2010), 413-435.

Woolf, Virginia: The New Biography. Collected Essays by Virginia Woolf, IV. Ed L. Woolf. The Hogarth Press, London 1967, 229-235.

Österberg, Eva: Individen i historien. En (o)möjlighet mellan Sartre och Foucault. Det roliga börjar hela tiden: festskrift till Kjell Peterson. Clio, Stockholm 1996, 321-332.

Östman, Ann-Catrin: Vad gör vi med historien? Om kvinno- och könshistoria i Finland. Scandia, Genushistoriens utmaningar. 2 (2012), 92-100. 
GENRE 


\title{
How does one relate a complex life? Reflections on a polyphonic portrait of the minister and intellectual Bodil Koch (1903-1973)
}

\author{
Birgitte Possing
}

In this chapter, I will reflect on the analytic keys of my biography on the Danish minister and intellectual, Bodil Koch that was published in Danish in 2007. Bodil Koch was an extremely high-profile and popular politician and minister during the period of the Cold War from 19501968. In spite of her position as a government minister for a period of more than fifteen years and her capacity as a provocative polemicist, intellectual, feminist and humanist, and in spite of the fact that her impact on the domestic and international politics had been immense, she had been marginalised in mainstream Danish national history. In my biography on her, I wanted to reestablish her visibility by writing her back into the national mainstream history. The question was how to do it.

The act of depicting Bodil Koch's national and international impact in her lifetime and reflecting on her significance for posterity was met with some paradoxes. The paradoxes leapt out at me from a painting in a museum. I happened to come across the Danish portrait painter Kirsten Kjær's oil painting of Koch, entitled Vision In Red, and I was stunned. This portrait was an explosive rendition of a woman on guard, a woman poised to jump, an ardent gaze with intense, well-defined eyebrows. The 
painting showed a sitter rendered as a medley of sparkling red, yellow, blue and green. A woman with a purpose, slender, head tilted, radiating an appealing volition. The portrait showed a woman in motion, a pro-active woman who would surely get things rolling. Yet, it was a disjointed mosaic, full of holes. The painting exuded a double-edged and enigmatic aura of focus and diffusion, of radiance and razor-sharp spotlights. In some mysterious way, all this had found its way into the ambiguous national, and international, discourse surrounding Bodil Koch. Inspired by the painting, I decided to write a biography of Koch based on her ambiguous aftermath.

\section{Split along two lines}

Conventional historiography regarding Bodil Koch had been split along two lines. One narrative showed her, the world's first female Minister of Ecclesiastical Affairs, Denmark's third female government minister, the academic, the devout Protestant and mother of five children, to have been an impulsive, female court jester, telling the truth but not being a proper politician. She was characterised as an awkward and inept representative for Danish and international politics in mainstream national history. The other narrative pointed to her as one of the twentieth century's foremost political talents, an advocate of modernity and humanism, a critic of Cold War mentality, and the feminist who cut the mustard as a purposeful man. In this latter narrative, Bodil Koch was characterised as the 'only real man' in the four governments where she held a position as minister, and as one of the most important figures in twentieth-century Danish domestic and foreign affairs. She carried the status as the Social Democratic party's biggest vote-catcher, having an enormous and rarely-matched impact on political life. Her contemporary political colleagues across party lines acknowledged her significance from an irritated or jubilant perspective according to where they stood on the political spectrum.

Why did she leave this enigmatic and contradictory reputation, where one interpretation actually precluded the other? How could 
How does one relate a complex life?

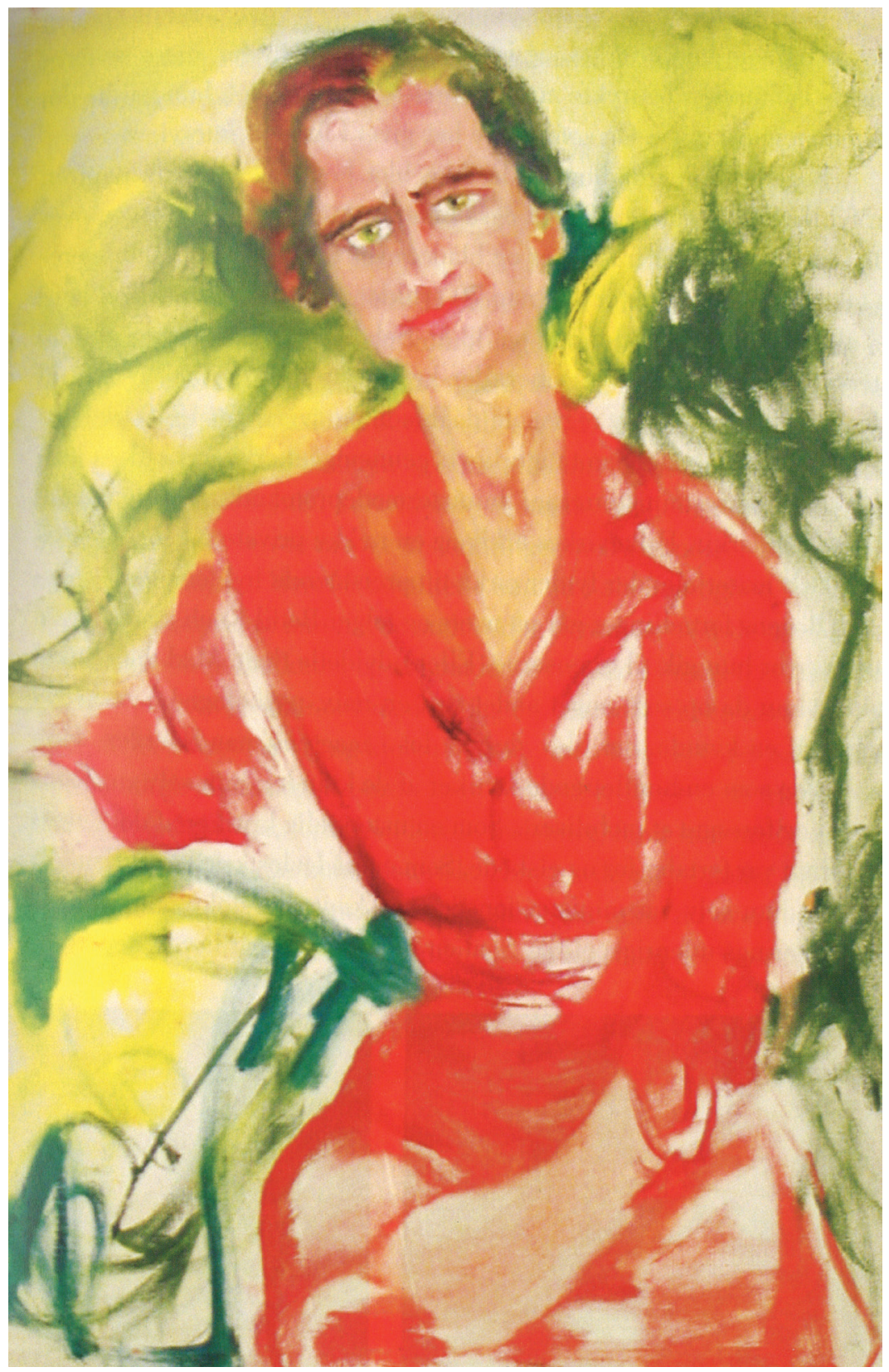

Bodil Koch by Kirsten Kjær, painted in May 1958. (Kirsten Kjær Museum, Denmark) 
public perception of her be so conflicting? I wanted to find an answer by repainting her portrait in words. I wanted to analyse her afresh in relation to the challenges of her day. That was the task I set for myself, starting with the challenge of finding the necessary biographical keys.

The notion of 'the only real man' signals traditionally male characteristics, such as purposefulness, firmness and courage, whereas the term 'court jester' signals traditionally female characteristics, such as irrationality, absurdity, amusement and impulsiveness. These incompatible characteristics were so inconsistent that they could hardly be used to refer to the same person. Or had Bodil Koch herself signalled an ambiguous nature that substantiated the contradictory reputation? If so, was this, in itself, a reason to give her such a transient position in historiography, as has been the case? Or, on the contrary, was there reason to recall a politician that had been an intellectual analyst flagging options for an alternative modus operandi? Koch had been a politician who challenged the prevailing political mind-set, the iced-over ideologies and inflexible political power manoeuvrings, both during the German occupation of Denmark in the Second World War and during the icy Cold War period.

Over and over again, Bodil Koch optimistically argued for the solving of political conflicts from a humanitarian approach rather than an ideological approach. In a television interview at the age of 68 , she said that from the outset of her political career she had decided 'to continue to be - naive'. Intentionally, Koch seemed to have put herself in that unusual position - on the one hand, as a responsible government minister for fifteen years, and on the other hand, as an anti-authoritarian intellectual provocateur.

I, thus, had to ask quite a basic question: Which were her beliefs? What was her mission as a politician? Why had this non-political academic, theologian and housewife gone into politics in the first place? What did she envision she would accomplish? What were her values, and why did they have such an impact in the public arena? Why did she hit the invisible glass ceiling in the power struggle of heavyweight politics and not get appointed as a Minister for Foreign Affairs, even though foreign policy was for her 'the being and essence of all politics'? 
What were the issues in her personal political manifesto, and how did she manage to get them writ large across the public stage?

\section{Changing biographical experience}

Compared with my former biographical work on the pioneering educationalist Natalie Zahle (1827-1913), the biography of Bodil Koch was intended to be of quite a different nature. While the biography of Zahle, Viljens Styrke. Natalie Zable. En biografi [The Strength of Will](1992), was directed at understanding the focused life aims of the pioneering woman behind the iconic myth and telling the story of her life, times and work, the purpose of the Koch biography was to listen to a woman with several voices speaking in diverse directions, creating a polyphony of visions that did not necessarily add up to a unified whole. Where the Zahle biography reconstructed the general public's image of a national icon, the Koch biography intended to challenge and deconstruct this same general public's view of a controversial but valued and much-loved politician. Where the Zahle biography aimed at rehumanising historiography and restoring the biography as a worthy, analytical genre in the discipline of history, the Koch biography intended to reinstate one of Denmark's leading ladies in national discourse and render her visible in a broad, political and intellectual public arena. While the Zahle biography was told as a classic life-and-times biography, as familiar from the Anglo-Saxon research tradition, the Koch biography was meant to redevelop the narrative conventions of this tradition. Of course, these different approaches would have consequences for the analytic method underlying the biography of Bodil Koch. In the following, I shall reflect on this process from the perspective of its contrast to my experience with analysis from the classic life-and-times biography. 


\section{Tracing a deliberate dismissal of letters}

Unlike my research into Natalie Zahle, who had left a comprehensive archive that included more than 3,000 letters, there was hardly a single letter to be found that was addressed to or from Bodil Koch. Systematically, she and her family had discarded the extensive correspondences she had conducted with many leading figures of her day. They were referred to in other sources. One of Koch's correspondents was her husband, Hal Koch. As a professor, folk high school principal and debater, he had been a public figure in Denmark both during and after the Second World War. His archive is preserved in the Danish National Archives, but contains no letters of import. Bodil Koch herself had kept all her speeches, drafts of articles and unpublished lectures from the first hesitant steps she took into the public arena in 1938 up until her death in January 1972. She did not, however, keep any of her letters. Her archives, which were not in any kind of organised order, were stored in the home of the youngest of her twin sons, Jens Koch, and they had yet to be collated in an archive with public access. ${ }^{1}$ Jens Koch invited me to visit him at his home so we could sort through the papers together. There I realised that he was in the process of throwing out what was left of his mother's collection of letters. 'Why?' I asked. 'What is written there is of no concern to anyone else,' he answered. Seeing my disappointment, he cheerfully increased it by giving me a list of names, some familiar, some unfamiliar, of living Danes he asked me not to contact as part of my research. He told me that there were matters pertaining to Bodil and Hal Koch that the family did not wish to see in the public domain.

That statement presented a research challenge. On the one hand, the researcher has to investigate all sources exhaustively in order to get as close as possible to available facts. On the other hand, when researching for a biography, the protagonist has to be treated, for ethical reasons, with respect and dignity. As a result, I faced a lack of letters that could

${ }^{1}$ This happened later, at my request. In 2008, following an agreement with the family, Bodil Koch's archive was incorporated in Arbejderbevægelsens Bibliotek og Arkiv (Library and Archive of the Danish Labour Movement) in Copenhagen. 
have afforded access to questions concerning which issues transpired in her, between her and all the people in her multifarious public network, and privately between her and her husband. Instead, I had a list with names of central sources that I was forbidden to contact. I made a decision that was to have great consequences for the analysis and the Koch portrait I was about to draw. I decided to approach her from outside instead of empathetically, and to focus on her work, her political visions and decisions rather than on her personal-private activities, feelings and understandings. With this approach, I met her emotional and private life challenges from an outside perspective; none the less, they ended up becoming part of the biography, as did a few letters that turned up during the work.

\section{Tracing sources other than letters}

So for sources, I would seek out her tracks in the manuscript archive, which unlike her letter archive was an almost complete record of her career. I planned to utilise the extensive collection of books and art she had left, and to which she had often referred in her speeches, in the relevant archives of the ministries for which she had been responsible Ecclesiastical Affairs and Culture - and also in minutes of cabinet meetings, which provide insight into the internal debates of any government in office. In addition, I would look in the archives of the Ministry of Foreign Affairs, because Bodil Koch was known, dreaded and respected throughout the world for her foreign policy speeches to the international forum. Her public reputation also meant that newspapers and other media were a natural source area I would have to trawl.

Once I announced that I was going to write a biography of Bodil Koch, my attention was brought to the existence of an archive from the women's and grassroots movement that Koch had instigated during the Second World War, and which, over the course of a few years, grew explosively, thus exercising a major influence on women's participation in the political democracy of the post-war period. The movement was known as the 'People's Work movement' (Folkevirke), the disorganised 
and extensive archive of which had been kept in private hands. This archive is now preserved for posterity in the Royal Library in Copenhagen, and it gave me access to completely new, hitherto unknown insights, both concerning the impact of the movement and as regards the way in which Bodil Koch made herself a public figure. Unlike work on the Zahle biography, my biography of Koch took shape over a lengthy period of time because of my professional job as a research director. In the fifteen years that passed before I returned to research, I spent some time familiarizing myself with the source material, reading up on Koch's era and political context and securing interviews with the central individuals who had known her, her closest circle and her political activities. These interviews constituted a completely different kind of source material, thus giving new perspectives on my protagonist. Letters, diaries and manuscripts are sources that provide access to the protagonist's own perceptions, longings and ideas, whereas interviews as source material allow access to others' perceptions of, reflections on, colours and nuances in the central character. Given that the letters were seemingly no longer to be found, these contemporaneous perspectives were essential. They yielded insights into Bodil Koch in the context of her times in a nuanced and vivid way.

\section{Tracing methodological approaches}

Initially, I had envisaged that a radical hermeneutic approach would allow me to get close to Koch from the inside outwards. Inspired by Toril Moi's The Making of an Intellectual Woman on Simone de Beauvoir, ${ }^{2}$ the working title The Making of an Intellectual Politician seemed an appropriate appellation for my projected biography of Koch. Thus, I imagined taking a chronological approach to tell a politically linear development story of this remarkable woman.

However, that analytical handle proved to be an illusory dead-end on two grounds. The deeper I read on her, the less coherent her train of

\footnotetext{
${ }^{2}$ Moi 1994.
} 
thought became. Her daughter, Dorte Bennedsen, who from the outset had not been too keen on the idea of someone writing a book about her mother, said to me: 'You cannot draw a portrait of Bodil Koch and say: That is Bodil Koch.' Gradually, I had to face up to the fact that she was right. She had also said, however, that her mother never gave up once she had set her mind on something. So likewise, I stubbornly decided not to abandon my desire to portray Koch in a biography.

I would have to choose a completely different approach. Here, the interviews paved the way. Through conversations with more than twenty of Bodil Koch's friends, colleagues, acquaintances, critics and admirers, her extraordinary calibre was confirmed. It became clear that her life should not be seen as a life that followed one continuous direction. Rather, a spectrum of longings, hopes, crises, conflicts and successes comprised the course of her life; a life running in different directions that, in many ways, did not harmonise. 'The life course did not accommodate to itself', as she herself stated to express the disharmonies of her life. Given that the interviews corroborated what the missing letters had told by virtue of their very disappearance - that Bodil and Hal Koch wanted to create a circle of emotional 'untouchableness' around their life together - it became clear to me that the biography should refrain from an understanding of her private life and from following a chronologicallinear route of her life. She wanted silence around her daily intimate family and social life.

Thus, I concentrated the analysis on her performance pursuing three fundamental questions: why did she have such extraordinary impact as a politician, what were the societal needs with which she connected and how did she do it? In this process, a new area of source material provided many keys to comprehension, namely the Danish Broadcasting Company's radio and television tape archive, to which Jens Koch drew my attention. The film director Boris B. Bertram, with whom I had made a film portrait of Koch, ${ }^{3}$ opened this archive to me. Now, with access to interviews and film and audio clips with and about Koch, I could compare her manuscripts and draft speeches with the speeches,

3 Store Danskere, Om Bodil Koch, DR2, Danmarks TV1, October 2005 (the film portrait has been broadcast several times). 
lectures and interviews she actually gave, and I noted that a significant thing happened to Koch in such a performative setting. She turned herself into an intellectually provocative, politically anti-authoritarian polemicist when she stood on a stage or in front of a microphone and a camera. Her exceptional charisma and rhetorical talent was exposed, and she got caught up in her own words, left her prepared script and entered into a dialogue with her audience, igniting a mutual enthusiasm. Inflamed by her own ardour, she surmounted the mood of doubt into which her thorough preparation for the speech had plunged her. Seen in this way, there was a clear coherence in her speeches that was not to be found in her written preparation. ${ }^{4}$ That challenge in the source material produced some unexpected opportunities for a re-portrayal of Bodil Koch.

\section{Tracing intelligent naïveté as a political challenge}

My objective was to explain and pin down the mystery of Bodil Koch's purpose, her visions, trying to explain why she was simultaneously perceived as provocative, intelligent, impulsive, naïve - and responsible. The answer was complex and would be found in a number of places, according to whether we see her as a politician, a government minister, a humanist, a feminist, a polemicist, a thinker, as a mother or as a wife. In my view, however, it would not be found in her childhood or upbringing as the traditional biographical conventions claim. In the twentieth century, the psychoanalytic paradigm concerning the development of human individuality has dominated the biographical genre. I wanted to walk along other lanes.

In 1941, when Bodil Koch was thirty-eight years old, she and Hal lost their fifth child, one-year-old daughter Bodil, who died from a rare blood disease. The family decided to repress their grief, and they would never again talk about the deceased little girl. After this, Koch une-

${ }^{4}$ Discovery of the inconsistency in Bodil Koch's written works led me to abandon my projected publication of her collected writings. 


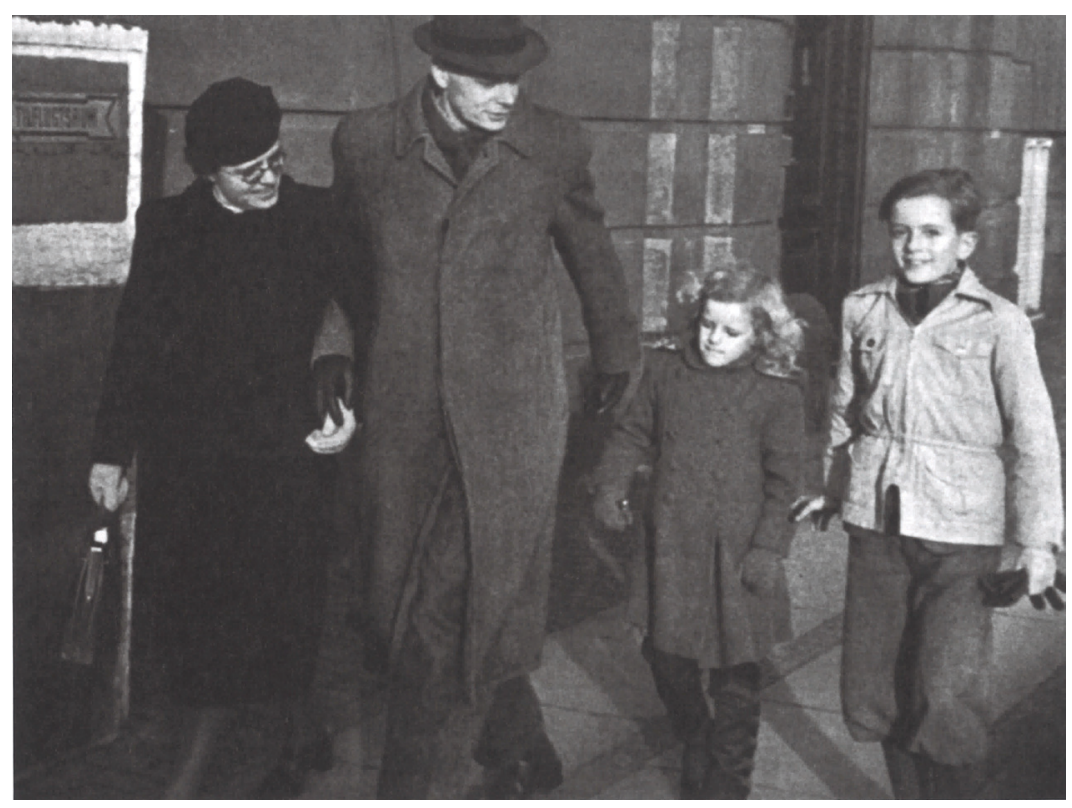

Bodil Koch and her husband Hal Koch with two of their kids, Paul and Marianne, autumn 1941. (Bodil Koch Archives, Arbejderbevægelsens Arkiv og Museum, Denmark)

quivocally gave up her role of housewife in the family. Following the outbreak of World War II and Denmark's occupation by Nazi Germany in 1940, Koch appeared angry that the national government had not offered more resistance to the occupying force, and she began to engage in public debate. In Sweden, Elin Wägner's book Väckerklocka ${ }^{5}$ had been published. It was a wide-ranging historical and matriarchal utopia; one long argumentation pushing for women to participate actively in public political life. Koch made sure it was translated into Danish with the title Ilden Overlever Natten. The book was translated and read throughout Europe, and it mobilised many intellectual women to partake in political work. ${ }^{6}$ In Denmark, it formed the theoretical foundation for the new women's movement, Folkevirke, which, spearheaded by Koch, had

\footnotetext{
${ }^{5}$ Wägner 1941.

${ }^{6}$ Leppänen 2005.
} 
an overwhelming impact among women generally. In the run of three years, 'Mrs. Professor Hal Koch' had turned herself into a high-profile public intellectual and feminist, carrying her own name, Bodil Koch, and paving her way for a career as a politician.

All in all, these discoveries meant that I took inspiration from Pierre Bourdieu's now classic article on the biographical illusion ${ }^{7}$ that questions the concept of coherence in the individual life. This approach supported my theory about the ambiguous and paradoxical aspect in an understanding of Koch and her societal influence. There were a number of contradictory lines in her thinking. They spanned and combined twentieth-century extreme ideologies in the Hobsbawmian ${ }^{8}$ sense: There were elements of liberalism, socialism, Protestantism, feminism, humanism and some conservatism in all her texts and manuscripts. It did not prove possible to fashion a meaningful interpretative framework for Koch's rendering of these ideologies, not even by viewing her as someone who reconciled dichotomies. The analysis constantly fell free from the ideological plait that I was trying to weave as a mode of understanding her. Perhaps one should take a more literal look at her and ask: What did her subjective vision, ambition and voice express??

In a long three-part interview published in 1963, the Danish journalist Malin Lindgreen caught Koch in a conversation expressing her own experience and memoirs as a learning process. Reading that, I was able to understand that Koch deliberately constructed the myth of her political and intellectual being. ${ }^{10}$ Through her political activities, Koch had taken an extremely purposive stand to maintain naïvité as a guiding principle to develop the democratic process. She claimed that politicians and ministers should make themselves useful to society in a modern democracy by repeatedly turning things upside down, by posing fundamental, banal and, thereby, naïve questions. Her political incentive was not the desire for power. It was a desire to affect public discourse and debate. As an ideal, she held the Hannah Arendtian view of democ-

\footnotetext{
${ }^{7}$ Bourdieu 1986.

${ }^{8}$ Hobsbawm 1994.

${ }^{9}$ In posing these questions, I was inspired by Liljeström 2004 and Scott 1992.

10 Scott 1992, 27-28.
} 
racy in modernity which emphasises democracy as in constant motion, changing and growing in an ongoing dynamic process. ${ }^{11}$ This, in Bodil Koch's opinion, was the most important basic condition of democracy.

In her public and political work, she decided to focus on four main questions: firstly, the question of how to explain the parallel existence of religious beliefs and technological insight and knowledge in the twentieth century; secondly, the question of how to develop internationalism and foreign politics in national states; thirdly, the question of how to install feminism and humanism pragmatically in daily life; and fourthly, the still more irrational question of how to use inspiration from modern art in culture and politics in the twentieth century. These were the questions that were fundamental and existential for herself as well as for her political impetus and driving force. Publicly, she gave words to existing taboos, not providing answers but by constantly raising questions.

Seen in that perspective, it was understandable why Bodil Koch was able to retain a position as minister for fifteen years in succession and under four successive prime ministers, irrespective of her ministerial responsibility and the ongoing, harsh criticism from her own government members. Her performative endeavour was to make herself into an intellectual minister who recreated democracy every day. Thus, she was able to embody a different kind of politics. She, herself, called it the tracing political naïveté that aimed at challenging the existing political ideologies. She succeeded, not in spite of her position as a woman pioneer in politics but, on the contrary, by deliberately using her gender in the male dominant parliament, to install herself in the role of court jester in public debate and on the parliamentary political scene. Instead of behaving as an excuse for herself, she presented herself as a challenge, consciously using her unusual and different voice.

${ }^{11}$ Benhabib 1996. 


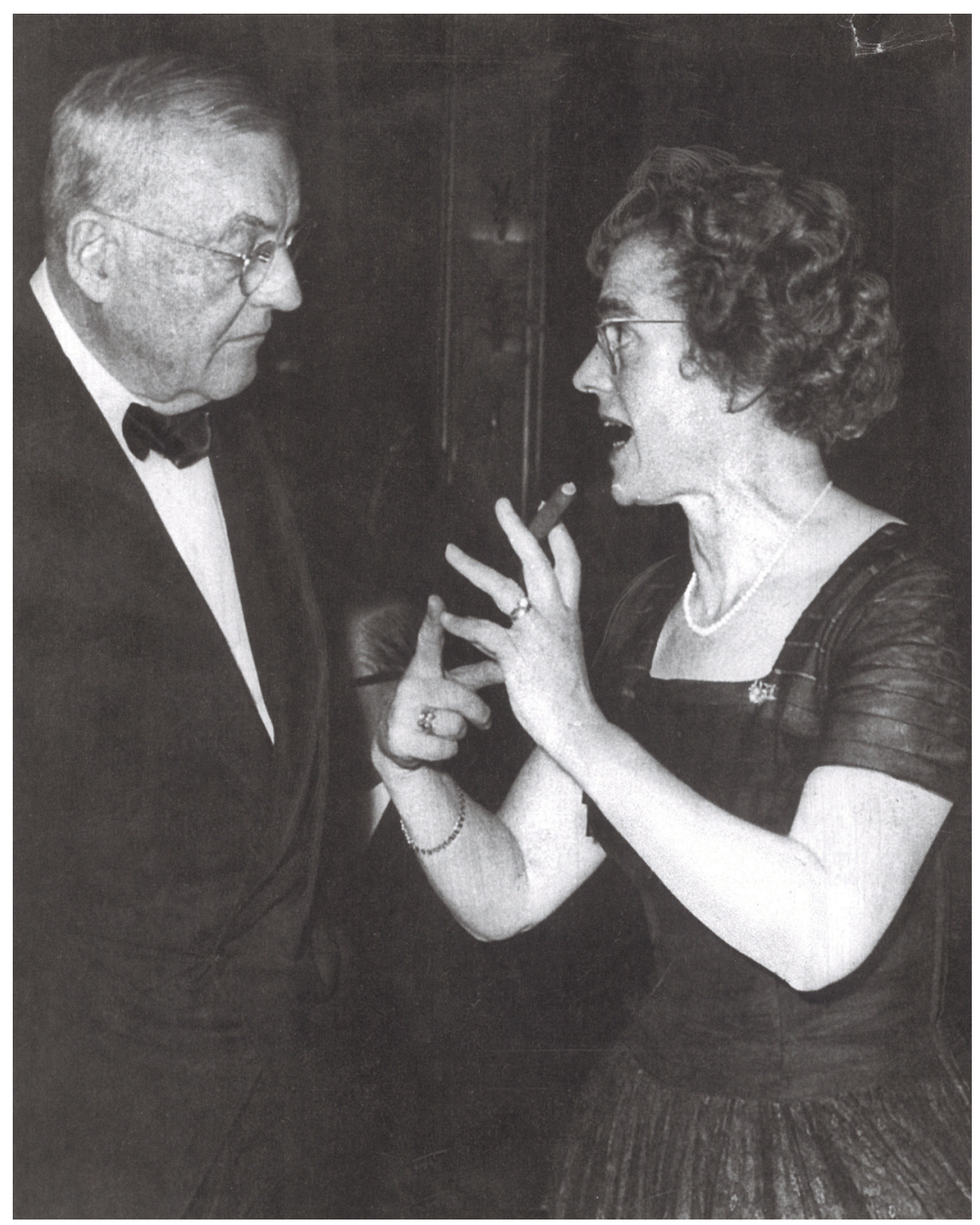

Bodil Koch and the American Minister of Foreign Affairs John Foster Dulles, May 1958. (Bodil Koch Archives, Arbejderbevægelsens Arkiv og Museum, Denmark) 


\section{Tracing a diet of opposites}

This, however, entailed another analytical enigma: How did Bodil Koch manage to place herself in and retain this position for a period of twenty-five years (she was an elected politician from 1946-1970)? Conventionally, we understand the intellectual critic's role in the state as a role independent of power. According to Edward Said ${ }^{12}$, the intellectual critic and the power broker are irreconcilable positions in a modern democracy. Without independence, there are no exposures or challenge to that power. As a member of a government, however, Koch had been a power broker and power administrator. How could she function as an agent provocateur in relation to the power that she herself represented? Having united this dual position in her fifteen-year service as government minister and twenty-five years as a politician during the Cold War, Koch should not be seen as someone who surmounted or reinterpreted twentieth-century extreme ideologies and developed a systematic new political thinking. She was neither an innovative theorist nor a pragmatic politician. She should rather be understood as the one-off who insisted on using her intellectual position in tandem with keeping her ministerial responsibility by playing on and with fragments of the existing ideologies and interpreting them in new ways.

Aware of the consequences - that her superiors would set limits to her power and influence - Koch assumed the double position as both intellectual critic of and responsible minister for the same government and power. Prior to her period as minister, she had presented herself from the podium of parliament as a critical and doubting heart. Some years later, from the same podium and now a minister, she had insisted that it was a duty for 'every thinking person' to 'be anti-authoritarian'. The only way Koch could stay in her role as intellectual and anti-authoritarian was to become her party's biggest vote-catcher. And she did. The Social Democratic Party could not afford to sack her from her post or expel her from the party, as others demanded on more than one occasion. On the other hand, four Social Democrat prime ministers could not afford to give her one of the most powerful posts - that of Minister for Foreign

${ }^{12}$ Said 2002. 
Affairs - when she kept insisting on her intellectual independence. Her deliberate double position as a responsible minister and an independent intellectual allowed her to make herself a kind of political-democratic valve in the bipolar world created by the Cold War. She loudly and clearly stated that it was better to 'thaw out than to freeze down', and she called for doubt and political self-criticism both in the East and in the West. At the same time, she took and administrated power as Minister for Ecclesiastical Affairs in one of Europe's most reactionary and male-dominated ministries. Moreover, she managed to legitimise national church affairs in the atheistic Social Democratic Party as well as the socialists' affairs in the national church. As Minister for Cultural Affairs, she succeeded in putting 'fragmented' advanced art on the agenda of people who otherwise loved comprehensible familiar art. She undertook a major feminist task in mobilising her female political opponents to become active in politics.

Thus, she lived her political life on a diet of opposites. When she left the post of minister in 1968, she told a television interviewer that from the beginning of her political career she had had one wish. That wish was to 'retain my naïveté in the original sense of the word, to be myself - from the inside'.

\section{Tracing a polyphonic portrait}

The compositional challenge for the Koch portrait was to make the reportrayal analysis fit the narrative structure of the book, so that I could include all the diverging narratives in one composition. Thus, I constructed the biographical portrait as a non-chronological, thematic narrative consisting of four principal lines. One line focused on the feminist and the democratic humanist, another on the internationalist and the Cold War critic, a third on the Protestant and ecclesiastical politician, and, finally, a fourth on the art critic and cultural politician. I included references, a register of sources, a bibliography and an index of names as guidance for potential further study by the political, the academic and the cultural readership. I removed, however, the scaffolding 
around the biographical house by not explaining my methodologicaltheoretical deliberations regarding the process to construct her portrait. The book would, thus, be more readily accessible to a general public unconcerned with scholarly problems.

In terms of composition, I framed the plot of the biography by beginning and ending with Bodil Koch as interpreted via paintings and photographs. I included the illustrations as a central aspect of the many narratives, with the size of each picture and placement on the page as an indicator of its significance. The illustrations were also the feature of the biography that was designed to tie it together chronologically. The photographs were interspersed throughout the book, following Bodil Koch from her childhood days up until a few weeks before her death. The illustrations showed life from cradle to grave, whereas the text showed that the life of our protagonist took more than one direction, often on a collision course, while reminding the reader of Koch's own saying that 'the course of life does not always accommodate itself'. This statement came to underlie the polyphonic, themed book I wrote about her. The silence that was struck up between the text, illustrations and picture captions was a deliberate part of the composition, intended to cover up what I, on ethical or irrational grounds, could not and would not write into the manuscript. I included Kirsten Kjær's two enigmatic 1958 portraits of Bodil Koch, one in the introduction and the other in the conclusion of the book. The biography was aimed solely at a general public, as well as being a challenge for an academic readership. The thematic form, the multiple voices, which were manifested in the structure and framework of the book, also led me to choose the title Uden Omsvøb. Et Portrat af Bodil Koch [To the Point. An Incisive Portrait of Bodil Koch]. The word 'biography' did not feature in the book's title.

\section{Tracing an ethical standing}

My position as a biographer in relation to Bodil Koch was based on wonder and bafflement rather than on fascination. I was neither driven by fascination nor reservation in an identity relation, the dual position 
I held with Natalie Zahle. Nor did I entertain any wish to legitimise Koch's political project. I was more concerned with rendering visible, explaining and understanding her as a controversial one-off in Danish political history. One of my aims was to reflect critically on the kind of politician she represented. In 1989, the Italian historian and biographer Giovanni Levi pointed out that ambiguities, contradictions and biographical polyphony had become ever more central to historians' interest. ${ }^{13}$ With the Levi-esque desire to capture the ambiguous and conflicting aspects of my main character's life and work, I would assume the role of an 'acute critic' in relation to Bodil Koch. The former British Prime Minister Arthur Balfour (1848-1930) is quoted as having said, 'biography should be written by an acute enemy'. ${ }^{14}$ That the biographer should play the part of the enemy is a little too strong of an expression for my taste, but the image of the detached and acute biographer, who impartially and as soberly as possible portrays his or her central character, defined my position as biographer in relation to Bodil Koch. In this respect, my own position with regard to Koch was further inspired by 'the father of historiography', namely Herodotus, and by the somewhat more modern Ryszard Kapuscinski's inquisitive joy in storytelling and taking the observational reporter position in relation to historical diversity. ${ }^{15}$

This did not mean, however, that the job was without any ethical dilemmas. Although Uden Omsvøb did not dwell on Bodil Koch's private or intimate relationships, I was faced with several ethical challenges, because she had adult children (and grandchildren) and a number of close and intimate friends who were still alive when I published the book on her. I did not need, as had been the case with Natalie Zahle, to keep a personal or secret work diary while researching and creating the Koch portrait. I had no need to record my personal feelings concerning the biography, because my relationship to Bodil Koch was nonemotional and un-ideological. On the other hand, I was sorely troubled when I received her son's list of people with whom I was not allowed to

\footnotetext{
${ }^{13}$ Levi 1989.

${ }^{14}$ Ratcliffe 1927.

${ }^{15}$ Kapuscinski 2008.
} 
seek an interview. Initially, I decided to comply. When I was later contacted by one of the people on that list, however, my dilemma loomed. She had heard that I was working on the book and she wanted to talk with me. I kept silent about the fact that her name appeared on the list of 'banned' interviewees, and agreed to meet with her. Given that she had taken the initiative to meet with me, I was not bound by a 'ban' that I had not even signed.

Once she told me her story, however, I had knowledge of some dramatic events and unusual intimate constellations in the Koch family universe that had actually had a bearing on their public positions and life's work. When I also, via a number of my interviewed informants, sensed that there were strong and crucial circumstances surrounding $\mathrm{Hal}$ and Bodil Koch that the interviewees were not prepared to divulge, and also that the couple's relationship with their children was emotionally un-clarified for all parties, I found myself in an ethical dilemma. Should I publish my knowledge from her as a 'forbidden' interview informant, given that it could have a bearing on the understanding of her public impact? Or should I keep silent about important explanatory mechanisms pertaining to $\mathrm{Hal}$ and Bodil Koch's actions, not involving these insights in the biographical analysis? After lengthy deliberation and critical reflection on my own era's insistent pressure for exposure of all the private and intimate details in the lives of the publicly known, famous personalities, I decided to go against the tide. I employed the Danish philosopher K.E. Løgstrup's concept of a 'zone of the untouchable'16 in relation to the inviolable ring that Bodil and Hal Koch had themselves established around them and their family. They happily spoke out about the practical turmoil of household duties and the ironic tone between them and their children, but anything to do with the emotional aspects and relations in and around the family were to remain private. This would also apply to posterity. Herein lay the explanation for the missing Koch correspondence. Deliberately, the family members had burned or discarded the letters. Only forty-four letters from Bodil to Hal Koch had survived, by chance. I found them in a file in the archives of the Ministry for Foreign Affairs.

${ }^{16}$ Løgstrup 1983. 
Equipped with knowledge from these forty letters and from the aforementioned forbidden interview, I decided to bring the 'zone of the untouchable' into the discourse to facilitate documentation of a special feature of the Koch family - a special feature that could be illuminated via quotations from some of the other interviews. I wanted to guide the public and coerce the readers into detecting some of the special patterns in Bodil Koch and her private life, of which I, as a researcher, was aware, and which had made it possible for her to operate as female government minister in a period when it was unusual to see a woman who had a husband and children taking on powerful positions in politics. I elected, however, not to name names nor to pass on the actual dramatic stories to which I was now privy.

By contrasting photographs with quotations from Koch's very few surviving letters, I did, however, try to reveal some of the private explanatory mechanisms concerning the relationship between $\mathrm{Hal}$ and Bodil Koch as structurally explanatory, without telling the actual stories with named persons who were still alive at the time. Thus, I chose to solve the dilemma by simply identifying the 'zone of the untouchable', i.e., casting some shafts of light across it without conveying the people involved. The specific private and intimate circumstance that the Koch family had wanted to keep private remained private and inaccessible. However, the readers and posterity still received a signal that there were some mysteries or a main enigma that could not be revealed in the book, but which held crucial points of understanding for Bodil Koch's thought patterns and conduct as a public persona.

Finding paintings and polyphonic portraits

During my work with the Bodil Koch portraiture, I found another oil painting of her made by the painter Kirsten Kjær that had been thoroughly hidden in the vaults of the museum. It was called The Closed Eyes. In fact, it was Kjær's first painting of Koch, and it showed her as someone other than the extrovert, engaged, pro-active woman who would surely get things rolling. The Closed Eyes portrayed Koch in trans- 
How does one relate a complex life?

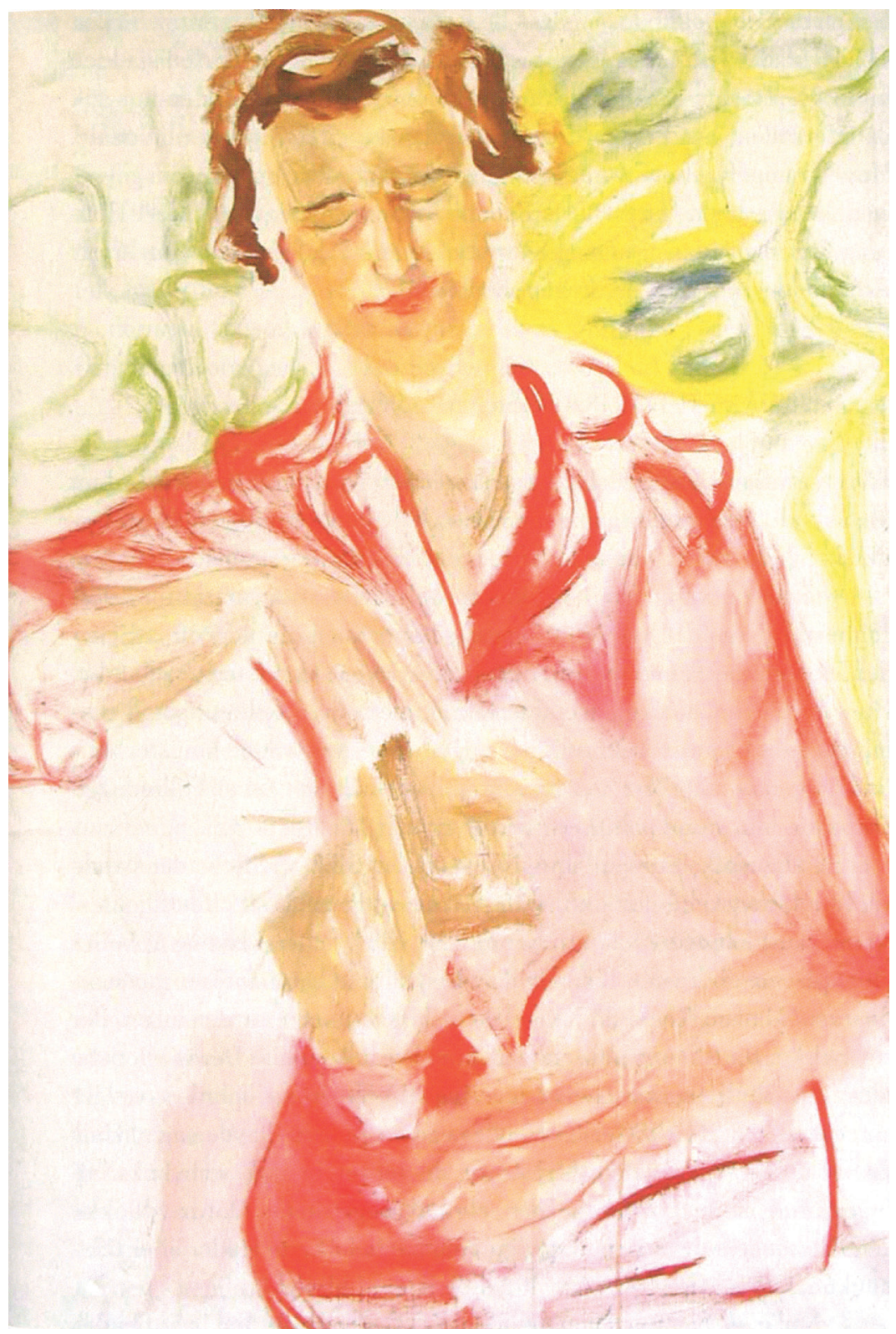

Bodil Koch by Kirsten Kjær, painted in May 1958. (Kirsten Kjær Museum, Denmark) 
parent colours with closed eyes, introvert and pale, as a sensitive woman in despair. Koch herself did not want the audience to see this part of her personality, so she asked the painter to destroy it and paint a new portrait. Kjær did the repainting, but she did not destroy the first portrait. Today, both paintings are exhibited side by side at the Kjær Museum, clearly showing the polyphonic character of Bodil Koch as minister, intellectual and humanist.

In retrospect, the geneses of the otherwise methodologically very different Zahle and Koch biographies have four common features in their analytic processes. The first was the aim to render visible two historically significant woman characters. The second feature was the ambition to understand the protagonists in national and international contexts. The third was the diversity of sources, and the fourth, the use of interdisciplinary analytic approaches. Nonetheless, the analytic processes behind the two biographies differed widely, in terms of biographical methodology. The Zahle biography forged new routes in Danish academia by means of rehumanising historiography, but in an international context, it was not theoretically innovative. The Koch biography, on the other hand, inscribed itself as a methodological experiment during the socalled biographical turn in public literature and history. ${ }^{17}$ The Zahle biography elucidated her impact on life-and-times biography. The Koch portrait focused on reportraying her in a de- and re-construction process. It was inspired by a social constructivist perspective on history, starting from new empirical evidence, and ending up explicating her impact in a polyphonic portrait with four vertical, in-depth, sectional views of the spheres where Bodil Koch had made the deepest imprints in history. These views revealed her as the critical internationalist who contested the Cold War mind-set, as the Christian humanist who expanded and challenged the broadness of the Danish state church, as the committed feminist who mobilised women across the board to politicaldemocratic activity, and as the radical cultural-liberal who prized the import of modern art and technology on new political visions. ${ }^{18}$ In the Zahle biography, the extensive surviving collection of correspondence

${ }^{17}$ Hamilton 2008; Klein 2009; Caine 2010.

${ }^{18}$ For a survey of biography archetypes, see: Possing 2001; Hamilton 2008. 
was of crucial significance to the analysis, whereas in the Koch biography, new insights came from analyses of manuscripts, interviews, printed and electronic media along with photographs and paintings. Here, I found new ways of painting my portrait, as challenged by the protagonist herself.

\section{Bibliography}

Benhabib, Seyla: The Reluctant Modernism of Hannah Arendt. Sage Publications, California1996.

Bourdieu, Pierre: L'Illusion biografique. Actes de la recherche en sciences sociales. No. 62/63, Editions de Minuit, Paris 1986, 69-72.

Butler, Judith and Scott, Joan: Feminists Theorize The Political. New York, London 1992.

Caine, Barbara: Biography and History. Palgrave and Macmillan, Basingstoke 2010.

Hamilton, Nigel: Biography. A Brief History. Harvard 2008.

Hobsbawm, Eric: Age of Extremes. The Short Twentieth Century 1914-1991. Abacus, London 1994.

Kapuscinski, Richard: Rejser med Herodot. Aschehoug, Copenhagen 2008.

Kaarsted, Tage: Krise og krig, Gyldendal og Politikens Danmarkshistorie, 1925-50. Vol. 13. Gyldendal, Copenhagen 1991.

Kaarsted, Tage: De Danske Ministerier 1953-1972. PFA Pension, Copenhagen 1992.

Klein, Christian: Handbuch der Biographie. Methoden, Traditionen, Theorien. Verlag F. B. Metzler, Stuttgart, Weimar 2009.

Leppänen, Katarina: Rethinking Civilization in a European Feminist Context: History, Nature, Women in Elin Wägner's Väckerklocka. Dept. of History of Ideas and Theory of Science, Göteborg University Press 2005.

Levi, Giovanni: Les Usages de la biographie. Annales ESC 6. Paris 1989, 1325-1336.

Liljeström, Marianne: Useful Selves. Russian Women's Autobiographical Texts from the Postwar Period. Kikimora Publications, Saarijärvi 2004.

Løgstrup, K.E.: System og symbol. Gyldendal, Copenhagen 1983.

Moi, Toril: The Making of an Intellectual Woman. Oxford University Press, Oxford 1994

Nissen, Henrik S.: Landet blev by. Gyldendal og Politikens Danmarkshistorie, 1950-1970. Vol. 14. Gyldendal, Copenhagen 1991.

Possing, Birgitte: Viljens Styrke. Natalie Zahle. En Biografi om køn, dannelse och magtfuldkommenhed. Vols. 1-2. Gyldendal, Copenhagen 1992.

Possing, Birgitte: The Historical Biography. Encyclopedia of Social \& Behavioral Sciences 2. Elsevier, Amsterdam, Paris, New York, Oxford, Shannon, Singapore, Tokyo (2001) 2015, $1212-1217$.

Possing, Birgitte: Zahle - Awakening the Promise of the Soul. Gyldendal, Copenhagen 2001.

Possing, Birgitte: Uden omsvøb. Et portrat af Bodil Koch. Gyldendal, Copenhagen 2007.

Possing, Birgitte: Fødslen af en sky. Review of K. Leppänen 2005. Kvinder, Køn og Forskning. $16: 4$ (2007). 
Possing, Birgitte: Portraiture and Re-portraiture of the Political Individual in Europe. Living Political Biography. Narrating 20 $0^{\text {th }}$ Century European Lives. Eds. Ann-Christina Lauring Knudsen and Karen Gram-Skjoldager. Aarhus University Press, Aarhus 2012, 33-53.

Ratcliffe, S.K.: Quote. The Observer, 30 January 1927.

Said, Edward: The Public Role of Writers and Intellectuals. The Public Intellectual. Ed. Helen Small. Oxford University Press, Oxford 2002, 19-40.

Scott, Joan: Experience. Feminists Theorize the Political. Eds. Judith Butler \& Joan Scott. Routledge, New York \& London 1992, 22-41.

Wägner, Elin: Väckerklocka. Bonnier, Stockholm 1941.

Wägner, Elin: Ilden Overlever Natten. Translated by A. Lading. Samleren, Copenhagen 1943. 


\title{
Biography as a way of challenging gender stereotypes: Reflections on writing about the Swedish author and feminist Frida Stéenhoff (1865-1945)
}

\author{
Christina Carlsson Wetterberg
}

This chapter is based on my biography of the Swedish author and feminist Frida Stéenhoff. ${ }^{1}$ The focus of Stéenhoff's world of ideas was on love, sexuality and motherhood. She was well-known in her time for her radical plays and social and political writings, but was also much debated, both by the intellectual male elite and within the women's movement. She cannot easily be placed into the lines of thought dominant at that particular point in time, and was later forgotten. One of the ambitions of the book is to study how Frida Stéenhoff was created as an intellectual and to inscribe her in a literary and political tradition. The book has both a narrative and an analytic ambition. The methodological reflections presented here were not developed before writing the book, but are an attempt to retrospectively understand the process and some of the results.

${ }^{1}$ Carlsson Wetterberg 2010. 


\section{Two strong narratives ready to take over}

When I presented my book at a seminar, someone commented that it must have been difficult to write a book about a woman who had seemingly lived a lucky life and had carved out some space as an author and intellectual. I was somewhat confused by the comment, and it made me realise how easily biography can be reduced to a narrative about a stable subject and a coherent life, and that, when women are at the centre, one often expects a story about a victim within a male structure. In fact, it was exactly this kind of simple and stereotypical narrative that I had struggled against when writing the book.

In retrospect, two major narratives, in research and in society, tried to take over my story. In the first, dominant at the time and within mainstream research, female authors are devalued and not taken seriously. This could be called the patriarchal narrative; a story that is formed by a male life course, where the important relationships are those between men and where the important authors are male. In this narrative, women's plays written around 1900 are either categorised as "tendency literature" or "indignation literature", without being attributed any real artistic value or interpreted as a purely biographical expression of life and not art. ${ }^{2}$ This is a narrative that feminist literary research has long tried to undermine. ${ }^{3}$ However, within feminist research, there has also been a tendency to get stuck in stereotypes and to force diverse experience into predetermined stories. Instead of a patriarchal narrative, a rigid gender order is placed over the story like a heavy grid, which actually means that it reproduces the patriarchal story, albeit in reverse. Literary scholar Lisbeth Larsson has pointed to this in her analysis of feminist biographies concerning Swedish women writers. ${ }^{4}$ The same point is made in The New Biography, edited by Jo Burr Margadant,

2 For a discussion of the concept "indignation literature" in relation to the concept "tendency literature" and their possible connection to male and female authorship in a Swedish context see Rydén 1987, 128-133; Gedin, 2004, 192-214: Englund and Kåreland 2008, 58-62.

3 See for example Nordin-Hennel 1993, 512-527; Williams 1997; WittBrattström 1997, 9-17; Larsson 2008.

${ }^{4}$ Larsson 2001, 408. 
where the ambition is to offer '... a different slant to those depressing tales' that are common within research. ${ }^{5}$

My ambition is not to deny the existence of gendered structures, but to highlight how they are manifested and whether and to what extent they affect an individual's life in a specific historical situation. I argue that this is actually an empirical question. Even if all women (and men) have to relate to these patterns, their strategies differ depending on who they are and how they live their lives. That was my starting point when I wrote the book, but the stereotypical gendered narratives, the patriarchal as well as the feminist, interfered with the process and made it more difficult to find and shape the story. I was faced with questions like: Did women's plays have any real artistic value? Was the political message of greater importance? Was the resistance to women writers very strong?

\section{Depicting a life}

In these postmodern times, few believe that it is possible to write a biography as a linear narrative, starting from the cradle and ending in the grave, with the ambition of finding the ultimate truth about a person's life. On the basis of this, one can either reject the genre as such or limit the claims to truth in different ways. The postmodern biographer does not claim to depict a real life, but works with texts and stories in which the self, the identity, is constantly constructed, deconstructed and reconstructed. ${ }^{6}$ However, even with this point of departure, if the text is not completely fragmented, the textual self needs to be interpreted and narrated in some way. For example, in her book on Simone de Beauvoir, Toril Moi leans heavily on psychoanalytic theory - a choice that, in itself, expresses a clear view of how a life should be understood. ${ }^{7}$ In my book, I choose a different path, also more comfortable for a historian,

5 Margadant 2000, 10.

${ }^{6}$ See e.g. Caine 2010; Possing 2015.

7 As Caine 2010, 99-100, has pointed out, in the first edition of her book on Simone de Beauvoir, Toril Moi did not want to call it a biography, but later changed her mind. See Moi 1994, 3-4, and the second edition 2008, 2. 
which accepts that identity is both multifaceted and changeable, but stresses that the individual life and agency always need to be understood from a cultural and historical perspective. I found my inspiration in the microhistorical tradition that values empirical details and focuses on how people think and act in their everyday lives. ${ }^{8}$

Initially, my ambition was to write a theoretically-driven and thematic biography, with theories of feminism and gender as linchpins. This did not really work. What ultimately gave my writing a boost was a total change of approach - to one that was chronological and very close to the source. The concept "clues", associated with the microhistorian Carlo Ginzburg, became a kind of methodological key in my research process. According to this perspective, the researcher's task is not to establish unequivocal causal relationships, but to arrange her or his clues in such a way as to allow for a credible story to emerge.?

Which clues you catch and what kind of story you compose is, of course, dependent on previous knowledge, theoretical preferences and the research question you want to answer. My ambition was to situate my protagonist in her time, to throw light on her development as an intellectual, to show how her life, writing and engagement were intertwined, and also to acquire more knowledge about the intellectual and political context of which she was a part. As my ambition was also to challenge the abovementioned delineated narratives - albeit more intuitively than consciously - it became important to be open to what the source material said and not downplay the contradictions and paradoxes that did not fit in. Thus, by working chronologically and very close with the empirical material, I began to see things that I would probably have missed if my approach had been different. Working in this way, my story began to take shape. The vague picture that I had of Frida Stéenhoff changed and a more complex picture emerged, of her, of the time and of the opportunities and obstacles that faced contemporary female intellectuals. Together with some examples, I will now try to illustrate how the two narratives were challenged by the empirical data. These illustrations appear under three separate headings: controversial

\footnotetext{
${ }^{8}$ See e.g. Davis 1995; Chartier 1997; Ginzburg 2012.

${ }^{9}$ Ginzburg 1989. See also Peltonen 2012, 45-76.
} 
and conventional, ethics and aesthetics, gender encompassing dialogues and new narratives. First, however, a few words about the protagonist herself.

\section{A brief background}

Frida Stéenhoff made her debut as a dramatist in 1896 with the drama Lejonets unge [The Lion $\mathrm{Cub}$ ] which she wrote under the pseudonym Harold Gote. At that time, both the problem-oriented drama and women writers had fallen into disrepute, which meant that it was not the most favourable time for a woman to publish a socio-critical drama. A new literary generation had now made an entrance; one that was critical of realism and that favoured emotion and fantasy. The role of author also became more masculine. Male authors were now 'the masters of the field', as one researcher put it. ${ }^{10}$ As indicated above, literature from the 1880s - which included women authors, was problem-oriented and focused on one's private life - was often dismissed as "indignation literature".

When Frida Stéenhoff published her first drama, she was 30 and had been married for eight years. At that time, Frida and her husband, Gotthilf Stéenhoff, who was a doctor, lived in Sundsvall, a sawmill town in the northern part of Sweden. Frida had been born in Stockholm and was the daughter of the famous clergyman and writer Bernhard Wadström, who eventually became very upset with his free-thinking daughter. Lejonets unge questioned both religious dogma and institutionalised marriage and suggested that only a relation that was based on love was morally defensible, whether legalised through marriage or not. This was the message in Frida Stéenhoff's first drama, which also contained a vague hint about birth control. When the drama was played out on stage, it caused great indignation and debate among the bourgeois establishment in Sundsvall. This was also the case wherever the drama was enacted. This debate and criticism does not appear to have bothered

\footnotetext{
${ }^{10}$ Gedin 2004.
} 
the author very much, but rather spurred her on. She was young and modern, and fully convinced that her ideas had a future. Frida Stéenhoff wrote several dramas in rapid succession and also began to engage in public debate, both in the pulpit and in her writings. She wrote and talked about prostitution, birth control, suffrage, marriage, war and peace, and constantly engendered debate, especially when living in Sundsvall, which she did until 1908. By 1918, eight plays, three novels and numerous social pamphlets, essays, articles and critical reviews in newspapers and magazines had been published.

Frida Stéenhoff was internationally oriented. She had broad interests and read a lot, often with her husband, and was keen to keep up with socio-critical fiction and specialist literature. Feminism, liberal theology and modern science, especially the theory of evolution, were all subjects that interested her. She was alone in calling herself feminist, a concept that even today is controversial in Swedish debate. ${ }^{11}$ She was an extremely controversial figure; not only for conservatives but also for the women's movement as a whole, which was generally more moderate and pragmatic. The militant methods used by the Suffragettes in England were dismissed, as well as the movements in France and Germany, which focused on issues related to love, sexuality and marriage. ${ }^{12}$

Frida Stéenhoff's thoughts can be placed in the latter tradition, together with those expressed by, for example, Katti Anker Møller in Norway, Rosa Mayreder, Helene Stöcker and Grete Meisel-Hess in Germany and Caroline Rémy in France. ${ }^{13}$ Frida Stéenhoff remained politically independent, but like many radical intellectuals of her time, she tried to unite thoughts about individual freedom with ideas about social responsibility and welfare.

${ }^{11}$ Stéenhoff 1903.

12 With regard to the early Swedish women's movement, see for example Björkenlid 1982; Levin 1994; Manns 1997; Rönnbäck 2004.

${ }^{13}$ Melander 1990; Allen 1991; Blom 1994; Roberts 2002. 


\section{Controversial and conventional}

For me, Frida Stéenhoff was a courageous and controversial woman, who challenged her time in its most contentious issues. She was an outsider. This perception of her also initially guided my questions and what I picked up from my sources. I was looking for evidence of her having faced resistance, and I was happy when I found formulations in letters like: 'I have to force myself a way' and 'I have come in embarrassing conflict with my family', and could use them as headings. I gradually realised, however, that my perception of her did not fit, and that something was wrong. Yes, she was criticised, but she also received much more support than I had expected, even from those who did not share her ideas. Moreover, it became clear that despite her controversial thoughts, she had, in many respects, lived a rather conventional life. She may have been an outsider in some respects, but not in others. The conceptual pair controversial/conventional emerged as an interesting paradox in her life that I was forced to reflect on. In this way, my understanding of my protagonist was deepened, and became more complex.

Photographs of Frida Stéenhoff show a beautiful and feminine woman. This was also noted by those who wrote about her. Her critics could not understand how this seemingly conventional woman could champion such outrageous ideas about sexuality and other controversial topics. She was 'a living antithesis', as one sympathetic author put it. ${ }^{14}$ This paradox of conventional and controversial could be interpreted in accordance with Joan Riviere, in her classical essay 'Womanliness as a Masquerade' from 1929, as a female strategy to be accepted in a male world. ${ }^{15}$ Historian Mary Louise Roberts has applied this perspective in an interesting analysis of a group of French women journalists and actresses in fin-de-siècle France. At the same time as these women broke with the prevailing gender conventions, by acting in public and demanding women's rights, they used and played out their femininity. As journalist and former actress Marguerite Durand put it, when responding to critics within the women's movement: 'Feminism owes

\footnotetext{
${ }^{14}$ Krey-Lange, Idun 19 December 1935.

${ }^{15}$ Riviere (1929) 2008, 25-33.
} 
a great deal to my blonde hair.' ${ }^{16}$ Roberts' purpose is not biographical, though. She is interested in how femininity is shaped and how it can operate subversively, albeit unconsciously. Theoretically, the analysis is inspired by Judith Butler, whose ideas about cross-border and subversion were, in turn, inspired by Riviere. ${ }^{17}$

It may be fruitful to consider Frida Stéenhoff and her authorship from a similar perspective. As a feminist, she was, of course, well aware of the prevailing gender conventions. I also discovered situations where she acted strategically in Riviere's sense. When it was suggested that an article about her should be illustrated with a photograph of her together with her daughter and cat, she wrote that: 'Their critical eyes could dwell on the child and the pet and be more lenient.' ${ }^{18}$ Thus, the apparent paradox between controversial and conventional is repealed, because emphasizing conventional femininity becomes a way of gaining acceptance for a controversial message. Margadant writes, in the abovementioned anthology, that, 'often the unconventional is a collage of familial notions merged in unfamiliar ways', thereby analytically destabilizing gender categories and relating them to an empirical historical context. ${ }^{19}$ It is likely that the kind of strategic thinking expressed by Marguerite Durand and Frida Stéenhoff is largely unconscious, but is, nevertheless, within the boundaries of a particular cultural context. To illustrate the importance of situating the analysis historically and culturally, it may be interesting to compare the image of my protagonist against that of Marguerite Durand provided by Roberts. The latter seemed almost unthinkable in the Swedish context of that time. Frida Stéenhoff extended borders in many ways, in her life and in her writing, but she was also rooted in a very Swedish and Lutheran culture. She soon became absolutist, but did not have the appearance of a 'demimondaine', as did Marguerite Durand. When Frida Stéenhoff and her husband visited Paris in the late nineteenth century, she wrote to her

\footnotetext{
${ }^{16}$ Roberts 2002, 49.

${ }^{17}$ Butler 1993.

${ }^{18}$ Letter from Ellen Key to Frida Stéenhoff 18 September 1897, from Frida Stéenhoff to Ellen Key 21 September 1897, in Carlsson Wetterberg 2010, 107-109.

${ }^{19}$ Margadant 2000, 2.
} 
father that she was happy that their Swedish hosts were not influenced by 'the self-indulgence and frivolity that rule here. Therefore he has no contact with the Swedish artists either, who have acquired a crude tone and arbitrariness in manners and ways of living. ${ }^{20}$

My ambition has been to understand how Frida Stéenhoff was created as an intellectual and feminist. Indeed, it was this combination of controversial and conventional that gave me a key to understanding why she could continue to write radical dramas and social pamphlets and not withdraw when her critics assailed her. However, to say that she lived conventionally is not completely accurate. Certainly, as a married bourgeois woman she was not financially dependent on her writing, but she lived with a man who was very unconventional for the time in that he gave his wife's writing and social engagement his full support. Even though she earned some money from her writing, she also realised that she was privileged at not having to write 'for bread'. ${ }^{21} \mathrm{Had}$ she chosen a different path in life, such as studying at university and following an academic career, she would probably have been able to support herself, although the limits for what she would have been able to say in public, especially concerning love and sexuality, would have been much tighter. An irreproachable reputation was of paramount importance for a woman to be taken seriously when entering the male-dominated public sphere. ${ }^{22}$ In this respect, there was no doubt about Frida Stéenhoff, even if her dramas were considered morally reprehensible. Both her appearance and her life functioned as a shield.

${ }^{20}$ Letter from Frida Stéenhoff to Bernard Wadström 1 May 1890, in Carlsson Wetterberg 2010, 72.

${ }^{21}$ Letter from Frida Stéenhoff to Ellen Key 12 October 1901, in Carlsson Wetterberg 2010, 137.

${ }^{22}$ See for example Ohlander 1987, 1; Rönnholm 1999; Hammar 2002, 116164; Markusson Winkvist 2003; Carls 2004. 


\section{Ethics and aesthetics}

As already indicated, there has been a tendency to place the late nineteenth-century female drama into the category of 'tendency literature', both then as well as in later research. This view was reproduced again a couple of years ago, when some of these Swedish plays were rediscovered and staged. ${ }^{23}$ This was also the case when one of Frida Stéenhoff's plays was reviewed under headlines such as 'A feminist pamphlet', or 'A political statement full of humour ${ }^{24}$ - formulations that are more applicable to politics than art. This means that these female plays are once again defined as 'women's literature' or 'programme literature', albeit in a more positive light, instead of being seen as part of a general literature in dialogue with its time.

When I started to work on the book I was interested in Frida Stéenhoff as a feminist who was engaged in the public debate, and not her plays. As a historian, I hesitated about approaching her literary works. However, it became increasingly apparent that it was artistic writing that was closest to her heart. When I realised this, I began to read her plays and their reviews and tried, through research, to get an overview of the literary climate of the time. I also found interesting texts, where Frida Stéenhoff herself reflected on the nature of art and the role of art in society.

I tried to approach the contemporary evaluations of Frida Stéenhoff's literary production with as few preconceptions as possible. It is true that she often received the kind of critique initially outlined in this article, especially for being too programmatic and, thereby, putting ethics rather than aesthetics at the centre. I also found, however, that many reviewers gave amazingly positive evaluations of Frida Stéenhoff as a playwright, taking her writing seriously and not focusing on it in terms of gender stereotypes. What was surprising for me, given that research often gives the impression that most women writers were seldom considered to have written what was considered good literature, was that

${ }^{23}$ During 2008 and 2009 plays written at the turn of the last century, both by Frida Stéenhoff and other women dramatists, were enacted on different stages in Sweden.

${ }^{24}$ Carlsson Wetterberg 2008. 
the picture was much more multifaceted than I had anticipated. Some critics were delighted with both the message and the artistic value, while others were totally ruthless in their negativity of both aspects. Another group rated the artistic value highly, but rejected the ideas behind it. For some, it was the other way around. A play could be highly valued for its ideological content, but be dismissed on artistic grounds. This study of the reception of Frida Stéenhoff's plays shows a much more complicated picture of the response to female authors than is usually assumed, thus contesting a simple analysis of women writers being positioned as victims in a male order. Some studies indicate this, but on the whole, very little research has been conducted, at least in Sweden, on literary criticism from a gender perspective. ${ }^{25}$

In terms of the importance of theoretical and methodological choices, I saw a more multifaceted picture emerging as a result of the conscious choice to try to work in as unprejudiced a way as possible and to be open to what the source material had to say. Positive criticism was discovered, which complicated the image of how women's writing had been treated.

The question of the relationship between ethics and aesthetics - between idea and art - is one that has engaged many philosophers throughout the ages and is just as relevant today. ${ }^{26}$ At the turn of the nineteenth century, with the emergence of realism and naturalism in modern literature, this issue sparked a particularly intense debate. In the Nordic countries, Danish critic and scholar Georg Brandes urged writers to 'put problems under debate'. This was also a central issue for Frida Stéenhoff, although she constantly defended herself against being defined as simply 'a program writer'. As she wrote to a friend and colleague in 1901: ' $\ldots$ it must be art not preaching. ${ }^{27}$ For her, literature included ethics and aesthetics. In her book entitled Teatern och livet [Theatre and life], published in 1910, she indirectly addressed her critics

\footnotetext{
${ }^{25}$ Arping 2013, 50-63. For studies showing a more complicated picture see for example Williams 2012.

${ }^{26}$ For an interesting current contribution see Winterson 1996.

${ }^{27}$ Letter from Frida Stéenhoff to Algot Ruhe 7 April 1901, in Carlsson Wetterberg 2010, 137.
} 
by writing that the author should depict true people from real life, their aspirations and dilemmas, without compromising artistic values. ${ }^{28}$

In this book, Stéenhoff defends artistic values and addresses universal questions about modern theatre, but does not address gender or feminism. With a more narrow gender approach, and with a focus on Frida Stéenhoff as a female writer in a male world, this book and the articles she wrote on this theme would probably not have been particularly interesting. What is also worth noting about the methodological questions addressed in this chapter is that neither this book nor the related articles stimulated debate or attracted special attention in the contemporary debate. This can be seen as an expression of a patriarchal order, where women lacked authority in these kinds of universal issues. It also shows that women were in dialogue with their time, and took themselves seriously as intellectuals.

\section{A gender encompassing dialogue and new narrative}

When I began to work with the biography, the women's movement and the feminist tradition of ideas were reasonable starting points. The problem was, though, that the empirical material did not conform to the categories and concepts developed within feminist historiography and theory, such as equality and difference, domination and subordination. These concepts, which I had already questioned as being too generalizing, did not fit in to my biographical narrative, either in terms of Frida Stéenhoff's life, as touched upon above, or her writing. ${ }^{29}$ She had a space, albeit limited, and at the same time as her texts addressed gender, they also dealt with things that had previously been hidden in a feminist context. By widening the scope, other contexts and other stories gradually emerged.

\footnotetext{
${ }^{28}$ Stéenhoff 1910, 16.

${ }^{29}$ Concerning the concepts of "equality" and "difference", see Carlsson Wetterberg 1998, 21-43 and 2004, 135-160.
} 
That a dialogue existed on feminism, particularly among women, is well-established within research. Was there, however, a dialogue on other topics, among women and between men and women? This is a question that is rarely asked or explored in research. In the biographies of male authors, women often feature as wives, sisters or lovers, but not as intellectual partners. ${ }^{30}$ Similarly, in women's biographies, the emphasis is often on women's networks and issues. However, what my study shows, as others also sometimes do even if it is not addressed theoretically, is that there was a more general dialogue among both men and women about a lot of currently debated issues in society, which is worthy of our attention.

Interestingly, a couple of recently published Swedish anthologies address the question of gender encompassing networks and friendships. ${ }^{31}$ The importance of considering the broader patterns of thought in society when approaching feminism and female intellectuals has also been emphasised in a recent book on the different positions of Swedish female authors in literary debates around 1900. In this study, the view of man is at the centre, not the differing views about the relationship between men and women or their respective natures. Instead, the key parameters are the dimensions science/religion and individualism/collectivism; an approach that makes the similarities between Ellen Key, Swedish feminist author and literary critic, and Frida Stéenhoff more important than their differing views on the nature of women. ${ }^{32} \mathrm{I}$ am not entirely comfortable with the analysis of Frida Stéenhoff's thinking as being extremely elitist and individualistic, but nevertheless, I welcome this new approach, which makes the analysis broader and more concrete.

The main point that I would like to make here is that the type of biographical approach I have chosen also results in a more complex pattern than is usually expected in research, both in terms of who speaks to whom and about what. After her literary debut, Frida Stéenhoff established contact with the radical cultural elite of the time through

\footnotetext{
${ }^{30}$ See for example Caine 2010, Williams 2012.

${ }^{31}$ Holmquist 2011; Berg, Florin and Wisselgren 2011.

${ }^{32}$ Stenberg 2009.
} 
correspondence and travel. She successively built up a supportive network of fellow writers and free thinkers and participated in societies and clubs consisting of both men and women. This was a time when ideological and political boundaries were still not clearly chiselled, and when the relationship between culture and politics was close. Like many radical writers and intellectuals, Frida Stéenhoff found herself in a kind of independent left position in the borderland between liberalism and socialism. It was apparently in this type of context, where both men and women participated and where there was an acceptance of different opinions, that she felt most at home and where her ideas had some support. Within these loose networks, fundamental social and cultural issues were debated, such as art and politics, peace and war, nationalism versus internationalism, individualism versus collectivism, and also ideas about love, marriage and morals. Feminism was included in these debates, even if it was not always obvious.

Frida Stéenhoff often lamented that male intellectuals did not understand the feminist stance, but, nevertheless, held onto a hope that one day they would. As she formulated it in the publication Feminismens moral [The ethics of feminism], feminism 'is no longer a battle between the sexes. Nor between classes. It is a battle between souls. ${ }^{33}$ It is obvious that some men supported the claims for gender equality posed by the women's movement, and that some also supported the more radical version of feminism advocated by Frida Stéenhoff. By taking this issue seriously, and by widening the analysis beyond a strictly feminist context, a more complex intellectual landscape is revealed. For a little while in the early 1900s, a dialogue that included both men and women challenged the narrative of modernity that began to be established at that point in time. Feminism was part of this dialogue, as were issues relating to love and sexuality, the horrors of war and the limits of individualism. This can also be regarded as a counter-narrative, in that it included topics that would otherwise have been marginalised.

${ }^{33}$ Stéenhoff 1903, 6. 
Biography as a way of challenging gender stereotypes

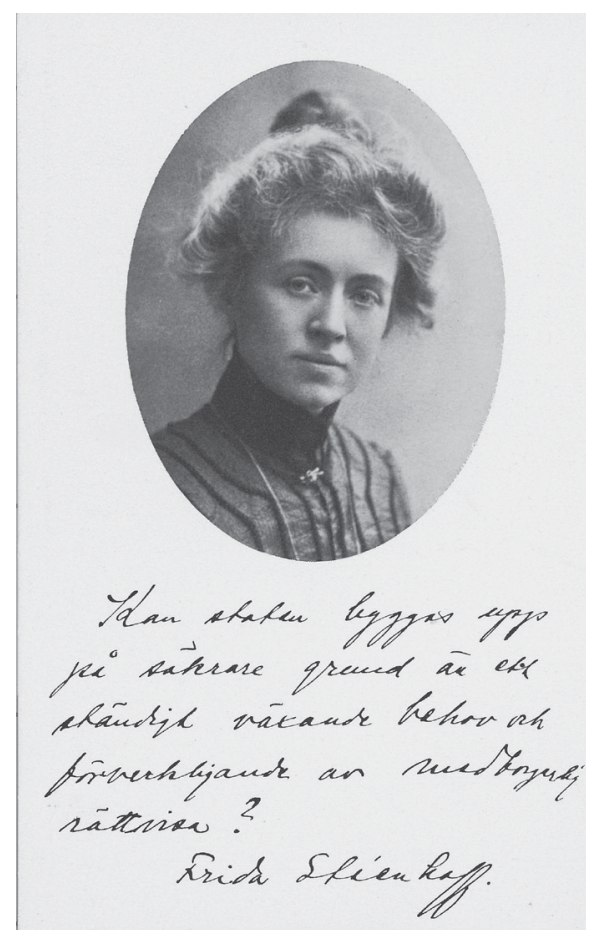

A postcard for women's suffrage. Frida Stéenhoff signed her photo with the following motto: 'Could the state be built on a safer ground than on a continuously growing need and realisation of human rights.' (KvinnSam, Gothenburg University Library.)

\section{Challenging hegemonic narratives}

To summarise, one could say that my biographical entry shows that male and female stereotypes are rarely encountered in real life. This does not mean that gender structures limiting individual action did not exist. The two strong stories that I initially outlined - simply referred to as the 
patriarchal and the feminist - were constantly questioned by the empirical data in my study:

1. Frida Stéenhoff was not an "outsider" in any simple sense.

2. The response to her literary works was multifaceted and included praise as well as criticism.

3. My protagonist did not identify herself or allow herself to be identified as just a woman or a feminist, but as an intellectual of the time.

4. Some intellectual conversations crossed gender borders.

5. New themes and stories emerged.

To borrow the words of Hayden White, my story is neither a success story nor a tragedy. It is not a simple story about a victim or a heroine. The portrait is more composed. Referring back to the comment directed to me - that it must have been difficult to write this book because my protagonist seems to have lived a happy life - I would say that the most difficult thing has been to go beyond the simplistic narratives of masculinity and femininity, which are not open to an analysis of women's latitude to speak and act.

Addressing gender without reinforcing gender stereotypes was and still is a difficult task. My way of doing it has been to work chronologically, close to the sources and, as much as possible, without prejudice. This has enabled me to see things that I would probably not otherwise have seen, such as the dialogue across gender boundaries and the challenging discussion about the relationship between art, politics and morality. By working in the way I did, I gained a deeper understanding of the relationship between Frida Stéenhoff's life and work and the period in which she lived.

\section{Bibliography}

Allen, Ann Taylor: Feminism and Motherhood in Germany, 1800-1914. Rutgers University Press, New Brunswick N. J, 1991.

Arping, Åsa: Från Hebbe till Hallberg - mot en kvinnornas kritikhistoria. Fält i förvandling. Genusvetenskaplig litteraturforskning. Eds. Eva Heggestad, Anna Williams and Ann Öhrberg. Gidlund, Möklinta 2013. 
Berg, Annika; Florin, Christina and Wisselgren, Per (eds.): Par i vetenskap och politik: intellektuella äktenskap i moderniteten. Borea, Umeå 2011.

Björkenlid, Bertil: Kvinnokrav i manssambälle. Rösträttskvinnorna och deras metoder som opinionsbildare och påtryckargrupp i Sverige 1902-1921. Litteraturvetenskapliga institutionen, Uppsala universitet 1982.

Blom, Ida: Voluntary motherhood 1900-1930: theories and politics of a Norwegian feminist in an international perspective. Maternity and Gender Policies. Women and the Rise of the European Welfare States 1880s-1950. Eds. Gisela Bock and Pat Thane. Routledge, London/ New York 1994, 21-39.

Butler, Judith: Gender Trouble: Feminism and the Subversion of Identity. Routledge, New York 1990.

Butler, Judith: Bodies that Matter: On the Discursive Limits of 'Self'. Routledge, New York 1993.

Caine, Barbara: Biography and History. Palgrave Macmillan, Basingstoke 2010.

Carls, Lina: Våp eller nucka? Kvinnors högre studier och genusdiskursen 1930-1970. Nordic Academic Press, Lund 2004.

Carlsson Wetterberg, Christina: Equal or different? - that's not the question. Is there a Nordic Feminism. Nordic feminist thought on culture and society. Eds. Drude van der Fehr, Anna G. Jonasdottir and Bente Rosenbeck. UCL Press, London 1998, 21-43.

Carlsson Wetterberg, Christina: 'Bara ett öfverskott af lif.' En biografi om Frida Stéenhoff (18651945). Atlantis, Stockholm 2010.

Carlsson Wetterberg, Christina: Efterlängtad dramatik. Sydsvenska Dagbladet, 4 March 2008.

Carlsson Wetterberg, Christina: Från patriarkat till genussystem - och vad kommer sedan? Genushistoria. En historiografisk exposé. Eds. Christina Carlsson Wetterberg and Anna Jansdotter. Studentlitteratur, Lund 2004, 135-160.

Chartier, Roger: On the Edge of the Cliff: History, Language and Practices. John Hopkins University Press, Baltimore 1997.

Davis, Natalie Zemon: Women on the Margins: Three Seventeenth-Century Lives. Harvard University Press, Cambridge, Mass 1995.

Englund, Boel and Kåreland, Lena: Rätten till ordet: en kollektivbiografi över skrivande Stockholmskvinnor 1880-1920. Carlssons, Stockholm 2008.

Fehr, Drude von Der; Jonasdottir, Anna and Rosenbeck, Bente (eds.): Is There a Nordic Feminism? Nordic feminist thought on culture and society. UCL Press, London 1998.

Gedin, David: Fältets herrar: framväxten av en modern författarroll: artonhundraåttiotalet. B. Östlings bokförlag Symposion, Eslöv 2004.

Ginzburg, Carlo: Threads and Traces: True, False, Fictive. University of California Press, Berkeley, California 2012.

Ginzburg, Carlo: Clues, Myths and the Historical Theory. The John Hopkins University Press, Baltimore \& London 1989.

Hammar, Inger: Alma Maters sedliga döttrar. Rummet vidgas: Kvinnor på väg ut i offentligheten ca 1880-1940. Eds. Eva Österberg and Christina Carlsson Wetterberg. Atlantis, Stockholm 2002, 116-164.

Holmquist, Ingrid (ed.): Könsöverskridande vänskap: om vänskapsrelationer mellan intellektuella kvinnor och män. Makadam, Göteborg 2011.

Krey-Lange, E.: Idun, 19 December 1935.

Larsson, Lisbeth: Hennes döda kropp: Victoria Benedictssons arkiv och författarskap. Weyler, Stockholm 2008.

Larsson, Lisbeth: Sanning och konsekvens: Marika Stiernstedt, Ludvig Nordström och de biografiska berättelserna. Norstedt, Stockholm 2001.

Lauritzen, Monica: Sanningens vägar: Anne Charlotte Lefflers liv och dikt. Bonnier, Stockholm 2012. 
Levin, Hjördis: Masken uti rosen. Nymalthusianism och födelsekontroll i Sverige 1880-1910. Propaganda och motstånd. B. Östlings bokförlag Symposion, Eslöv 1994.

Manns, Ulla: Den sanna frigörelsen. Fredrika-Bremer-Förbundet 1884-1921. B. Östlings bokförl Symposion, Eslöv 1997.

Margadant, Jo Burr (ed.): The New Biography: Performing Femininity in Nineteenth-Century France. Univ. of California Press, Berkeley 2000.

Markusson Winkvist, Hanna: Som isolerade öar: De lagerkransade kvinnorna och akademin under 1900-talets första hälft. B. Östlings bokförlag Symposion, Eslöv 2003.

Melander, Ellinor: Den sexuella krisen och den nya moralen: förhållandet mellan könen i Grete Meisel-Hess' författarskap. Almqvist \& Wicksell International, Stockholm 1990.

Moi, Toril: Simone de Beauvoir: the Making of an Intellectual Woman. Blackwell, Oxford 1994.

Moi, Toril: Simone de Beauvoir: the Making of an Intellectual Woman. The second edition. Oxford University Press, Oxford 2008.

Nordin-Hennel, Ingeborg: Strid är sanning, frid är lögn. Nordisk kvinnolitteraturhistoria. Bd 2, Fadershuset: 1800-talet. Eds. Elisabet Møller Jensen and Inger-Lise Hjordt-Vetlesen. Wiken, Höganäs 1993, 512-527.

Ohlander, Ann-Sofie: En utomordentlig balansakt: Kvinnliga forskarpionjärer i Norden. Historisk tidskrift. 1 (1987), 2-22.

Peltonen, Matti: The Method of Clues and History Theory. Historical Knowledge: in Quest of Theory, Method and Evidence. Eds. Susanna Hellman and Marjatta Rahikainen. Cambridge Scholars, Newcastle upon Tyne 2012, 45-76.

Possing, Birgitte: In Search of the Methodological Keys to a Biographical Analysis. Qualitative Analysis in the Making. Eds. Andreas Bandak and Daniella Kuzmanovic. Routledge, London 2015, 25-43.

Riviere, Joan: Womanliness as a masquerade. Orig. 1929. Reprinted in The Routledge Critical and Cultural Theory Reader. Eds. Neil Badmington and Julia Thomas. Routledge, London 2008, 25-33.

Roberts, Mary-Louise: Disruptive Acts: The New Women in Fin-de-Siècle France. The University of Chicago Press, Chicago 2002.

Rydén, Per: Domedagar: svensk litteraturkritik efter 1880. Litteraturvetenskapliga institutionen, Lunds universitet, Lund 1987.

Rönnbäck, Josefin: Politikens genusgränser: den kvinnliga rösträttsrörelsen och kampen för kvinnors politiska medborgarskap 1902-1921. Atlas, Stockholm 2004.

Rönnholm, Tord: Kunskapens kvinnor: sekelskiftets studentskor i mötet med den manliga universitetsvärlden. Institutionen för historiska studier, Umeå universitet, Umeå 1999.

Stéenhoff, Frida: Feminismens moral: föredrag hållet i Sundsvall den 30 juni 1903. Wahlström \& Widstrand, Stockholm 1903.

Stéenhoff, Frida: Teatern och livet: några tankar om dramatiskt konst i nutid och framtid. Björk \& Börjesson, Stockholm 1910.

Stenberg, Lisbeth: I kärlekens namn: om människosynen, den nya kvinnan och framtidens sambälle i fem litteraturdebatter 1881-1909. Normal, Stockholm 2009.

Williams, Anna: Kvinna och åttiotalsförfattare. Victoria Benedictsson, Ann-Charlotte Leffler och Alfhild Agrell i litteraturhistorien. Bakom maskerna. Det dolda budskapet hos kvinnliga 1880-talförfattare. Ed. Yvonne Leffler. Centrum för språk och litteratur, Högskolan i Karlstad, Karlstad 1997, 19-46.

Winterson, Jeanette: Art Objects: Essays on Ecstasy and Effrontery. Vintage, London 1996.

Witt-Brattström, Ebba: Ediths jag: Edith Södergran och modernismens födelse. Norstedt, Stockholm 1997. 
GENDER 


\title{
A biography of her own: ${ }^{1}$ The historical narrative and Sigríður Pálsdóttir (1809-1871)
}

\author{
Erla Hulda Halldórsdóttir
}

On the 25th of last month, in her 62nd year, the notable widow and housewife Sigríour Pálsdóttir (the daughter of the county magistrate Páll Guðmundsson of Krossavík) died at Breiðabólstaður in Fljótshlíð, born at Hallfreðarstaðir in Hróarstunga on 17 May 1809. Her first husband was the notable priest Porsteinn Helgason at Reykholt, and her second marriage was to Sigurður Gíslason Thorarensen, who was a priest at Hraungerði. She was his second wife. Later, there will be a more detailed biography in this paper. ${ }^{2}$

The announcement of the death of Sigriłur Pálsdóttir, published in the newspaper Fjóðólfur in April 1871, is fascinating. An entire life is packed into one paragraph, framed by birth and death - a microbiography. It is full of facts, yet there is nothing about Sigríður's ${ }^{3}$ life beyond

${ }^{1}$ It goes without saying that this is a reference to Virginia Woolf's $A$ Room of Her Own.

2 [without a title], Fjóðólfur 28 April 1871, 102-103.

${ }^{3}$ Hereafter I will refer to Sigríður Pálsdóttir by her first name, as is customary in Iceland. The same applies to other names. Where necessary both first name and surname are used, for instance when distinguishing between Sigríður and her grandmother, Sigríður Ørum. 
the names of three men that shaped it in one way or another, namely her two late husbands and her long dead father. There is no surprise in this, as women were defined by their marital status and family relations. Still, Sigríður was, according to the announcement, a 'notable' woman. ${ }^{4}$ What that means is not explained and the more detailed biographical note ${ }^{5}$, which would have justified her notability, never emerged. ${ }^{6}$

A longer, yet imperfect, version of her life could be as follows: Sigríður Pálsdóttir was born in eastern Iceland in 1809. Her father was a county magistrate $^{7}$ who died in 1815 leaving behind a widow and five young children, the eldest only nine years old, the youngest, twelve weeks. Sigríður was the second eldest. In 1817, her older brother Páll Pálsson (b. 1806) was sent away to be fostered and educated by a friend of the family in southern Iceland. This marked the beginning of a systematic correspondence between Páll and his family and friends. Among the correspondents were his mother, grandmother and siblings. ${ }^{8}$ Sigríður's first letter to her brother was written in December 1817 and the last in February 1871, a total of 250 letters in all.

In 1829, Sigríður left her childhood home and travelled across the country to work as a housemaid in Reykjavík. She fell in love with Porsteinn Helgason, a young intellectual who had just returned to Iceland from Copenhagen after years of studying. They married in 1833. After having suffered from mental illness, however, he drowned tragically in

4 'Merkiskona' is translated as 'notable', but it can also be used to mean a distinguished or remarkable woman.

5 The word used in the announcement is ' $æ f i a t r i ð i '$ '. It could be translated as 'facts of life', or a short biography.

${ }^{6}$ The possibility of writing a biographical text or obituary about Sigríður is mentioned in a letter Skúli Gíslason, her son-in-law, wrote to her surviving brother, Páll Pálsson. Obituaries of this kind were frequently published in the newspapers. See National and University Library of Iceland, Department of Manuscripts (hereafter NULI), Lbs 2412 a 4to Skúli Gíslason to Páll Pálsson, 11 Apríl 1871.

7 In Icelandic: sýslumaður.

8 Páll Pálsson's archive is preserved at the Department of Manuscripts at the National and University Library, Reykjavík, Lbs 2409-2415 4to. Sigríður's letters are in folder $L$ bs 2413 a 4 to. On the family and their correspondence see Halldórsdóttir 2015a. 
1839. Sigríður married again in 1845 , was widowed for the second time in 1865 , and died in 1871 at almost 62 years of age. She had six daughters, three of whom died in infancy.

There are gaps in Sigríður's writing and the number of letters written each year varies. The correspondence, nevertheless, covers almost her entire life. I have been exploring Sigríður's life and letters, concentrating on the complex and dynamic world of correspondence and family networks, and I am currently writing her biography.

This chapter focuses on opposing views on historical biography in relation to the eligibility of female subjects, while using Sigrídur Pálsdóttir's life and letters as my case study. I argue that although feminist historians and biographers are increasingly interested in and are, indeed, calling for more biographies and biographical research about ordinary lives, these lives are still not accepted as valid subjects unless as collective biographies or as a microhistorical study. One of the reasons for this, I argue, is biography's inherent resistance to accepting the ordinary as a suitable subject, and biography's lack of framework for such life stories. As a consequence, I refuse to write about Sigríður as a representative of other women and argue, instead, that she is worthy of a biography of her own.

\section{Ordinary but notable woman}

Writing the biography has proved more challenging than I anticipated, not because of the selecting and shaping required to interpret a life doing historical biography, just as history, is about selection, shaping and interpreting. ' Writing Sigríður's life has been challenging because there is a limited space for the telling of an ordinary life, as hers, as an historical biography. There is a claim for worthiness, for exceptionality when writing a biography, in particular if it is about a woman's life. Furthermore, there is a strong need to link her to the grand narratives of history as a representative of a social group or of an era, instead of

\footnotetext{
${ }^{9}$ See e.g. Lee 2009.
} 
being a historical agent in her own right. Sigríður Pálsdóttir does not, however, fit nicely into available categories.

Sigríður's letters reflect a determined woman who wanted to be an agent of her life and who made the most of her prospects. The letters are, nonetheless, ordinary in the sense that they reflect daily life and practical issues. Sigríður had good handwriting and her letters were intelligently styled, often sharp. However, if measured by the features usually praised in women's letters, which is their poetic writing and reflections on literature and society, Sigríður does not fulfil the criteria. ${ }^{10}$ They are, in fact, more like the writings of the ordinary people historian Martyn Lyons describes as being 'laconic rather than reflective, pragmatic rather than introverted'. ${ }^{11}$

Therefore, Sigrídur may have been notable in the eyes of those who knew and loved her, but she is not exceptional in a historical context and she is not one of the notoriously few women that have earned their place in the grand narratives of Icelandic history. Sigríður, in fact, did nothing during her lifetime that has, to date, made women worthy of biography.

She did, however, leave a story behind. Although it is not an exceptional story, her letters portray a lifespan that seems somehow extraordinary and reflect the continuity and change of a life from 1817 to 1871. As the Italian philosopher Adriana Cavarero eloquently reminds us, the 'fact remains that not only the exceptional leave behind a story'. As Cavarero argues, each individual is unique and no two life stories can be the same:

[--] any woman, who is the biography's protagonist, shows herself to be unique and unrepeatable. Her life-story, before bearing witness to the historical typology of a class or a condition of women, puts into words, above all, the uniqueness of her personal identity. ${ }^{12}$

In other words, an individual, first and foremost, represents herself and not the lives of others.

\footnotetext{
${ }^{10}$ E.g. Dowd and Eckerle 2007; Earle 1999; Kenyon 2003; Caine 1994, 250.

${ }^{11}$ Lyons 2014, 249.

${ }^{12}$ Cavarero 2000, 70-71.
} 
Still, notwithstanding new approaches and theorising, the field of biography is still hierarchical in nature and permeated by claims of worthiness and representativity that can hinder its development. ${ }^{13}$ As a consequence, the historian, the biographer, who has chosen an 'ordinary' woman's life to study, begins to doubt the worthiness of her protagonist, and starts seeking justifications for doing that research instead of concentrating on the evidence left behind and the story revealed.

There is, for instance, biographer Paula Backscheider, who argues that 'the primary purpose of the genre of biography [is] ... to give a vivid picture of an interesting person whose life matters. ${ }^{14}$ This is a valid perspective, but it leaves us with the question of how to define 'interesting' and what kind of a life 'matters'. What does it take for a life to matter and who determines that?

Furthermore, historian Susan Ware claims that historians engaging in biography usually choose their subject in relation to 'his or her position in a larger historical moment or paradigm shift, because they want to tell a wider story than that of one individual life'. Hence, Ware argues, 'the challenge is to use the individual as a window on a wider vista. ${ }^{15}$ The individual as a window to the past is a standard reasoning for studying and writing about those who would otherwise not be considered worthy. Therefore, the protagonist not only acts as a prism to look through, but also as a representative of a particular group, era, class, and sex. ${ }^{16}$

While agreeing that the individual can be used as a window to the past, I believe there is a certain discrepancy in this perception. If worthiness is measured by representativity, or how much (and to what extent) a life can be used to illuminate historical process, then the individual, and her story, are of no importance in themselves.

${ }^{13}$ For views on biography see e.g. Caine 2010; Hamilton 2009; Ware 2010; AHR Roundtable. Historians and Biography 2009.

${ }^{14}$ Backscheider 1999, xviii.

15 Ware 2010, 422-424.

${ }^{16}$ Caine 2010, e.g. 1-2, 23-27; Hamilton 2009, 8-9; Possing 2005; Ware 2010, 413-435; Backscheider 1999, e.g. 37, 49. 


\section{Women's biographies}

Historical biographies of women are an old genre, but it was the emergence of academic women's history and the new women's movement in the early 1970s that sparked the rise of historical biographies of women. ${ }^{17}$ However, just as the discipline of history was structured around men's lives and achievements so was the historical biography, i.e., birth, upbringing and education, career or achievements, death. There was little or no room for a private life. This frame of narration did not suit most women's lives and it was, as Barbara Caine argues, 'almost impossible for women to "qualify" as suitable subjects for biography'. Hence, feminist historians wrote about exceptional women or those whose contribution to society counted as significant, the so-called 'women worthies'. Such life stories could be moulded into the traditional male biographical form. ${ }^{18}$

Female biographers and autobiographers found it difficult to find and establish a legitimate voice for women outside of the traditional (masculine) definitions of worthiness, as Carolyn Heilbrun argues in Writing a Woman's Life in $1988 .{ }^{19}$ Even when working on worthy (male) subjects, women's voices as biographers were not thought to be 'magisterial' enough for writing 'great' biographies, as Paula Backscheider experienced. ${ }^{20}$

In an inspiring article on biography and feminist history in 1994, Barbara Caine argued that biography was, in fact, 'antithetical to some of the basic aims and approaches of women's history'. Caine stated that the principal aim of women's history was to retrieve, explore and explain the lives of ordinary women. Therefore, stories of exceptional women, 'women worthies', did not illuminate everyday lives. The paradox is, Caine continues, that biography is also 'the avenue that seems most helpful for those seeking to understand the actual historical experi-

\footnotetext{
${ }^{17}$ Caine 2010, e.g. 44-46; Heilburn 1988; Ware 2010; Margadant 2000.

${ }^{18}$ Caine 2010, 106. Also on women's biographies Ware 2010; Backscheider 1999; Caine 1994; Alpern 1992; Heilburn 1988.

${ }^{19}$ Heilburn 1988, 11-31, 40.

${ }^{20}$ Backscheider 1999, 18-22.
} 
ence of women in all their complexity'. ${ }^{21}$ Caine, working on Victorian feminists, cautions against trying to mould the different experiences of women and their varied lives into the same trajectories. Women's lives, she argues, must be 'understood and explored from within the context of feminist history rather than to be written as heroic accounts of great and unusual women'. ${ }^{22}$ Hence, feminist historians must step beyond the framework of remarkable or heroic life stories.

However, twenty years on, accounts of exceptional women, feminists or not, and their heroic acts, continue to haunt feminist historical biography. Grounding her argument on extensive reading of historical biographies, Paula Backscheider argued in 1999 that historians were struggling with relating women as historical agents to 'the larger picture of historical change. ${ }^{23}$ I believe this is still the case. Even though feminist biographers and historians stress the importance of exploring and writing the lives of ordinary women, instead of those who count as significant, ordinary women seldom become biographical subjects because of their own individual lives, but rather as representatives or symbols for some particular group of women.

This perspective is epitomised in the editorial note of the Journal of Women's History, in a special issue on 'individual lives' in 2012. The editors write straightforwardly that when receiving 'submissions of biographical account' they often 'reject these outright'. Their reasoning is that:

[--] biographical work that treats individual life stories as if they were historically significant all by themselves - work that stares at its subject rather than 'see[ing] through' it, to use the historian Alice Kessler-

${ }^{21}$ Caine 1994, 250.

${ }^{22}$ Caine 1994, 259.

${ }^{23}$ Backscheider 1999, 151. As Backscheider herself states the books she takes under consideration are mostly biographies that have been shortlisted or won prizes. Her choice results 'in some neglect of academic biographies', xix. However, her book includes a chapter about feminist biographies and the challenges of writing a woman's life - and of being a female (auto)biographer. 
Harris's apt phrase - does not sufficiently advance the scholarly goals of the Journal. ${ }^{24}$

The individual stories told in the special issue of the Journal of Women's History did however fulfil the prerequisites of the editors and 'set their subjects in the context of major historical themes and transformations that include revolution, capitalism and imperialism, politics and resistance, and the work of self-representation'. ${ }^{25}$

As already stated, I do agree that individual lives can be used to illuminate processes and change in society, but I fundamentally disagree with the view indicated in the quote above. If the worthiness of an individual from the past, in my case the life of an ordinary woman, is embedded in her representativity, there is only one legitimate way to explore her life and to write her biography, and that is to weave her life into the grand narratives of history, to make her a window to gaze through. One way is, for instance, to explore how she experienced the conflict between private and public life, which has been one of the main premises of feminist biography. Susan Ware defines feminist biography as follows:

The key [to feminist biography] is a focus on gender as a primary influence on women's lives. Feminist biography posits that traditional narrative arcs that trace a male model of success or achievement do not necessarily apply to female subjects. Women's public lives rarely unfolded in straightforward ways; they were often complicated by struggles to obtain education, find productive work, or to escape the expectations of traditional female roles and other distractions like marriage or motherhood. More than anything else, the hallmark of feminist biography is close attention to the connections between subjects' personal and professional lives. ${ }^{26}$

${ }^{24}$ Quataert and Wheeler 2012, 3. The reference to Kessler-Harris is in AHR's roundtable on biography in 2009. See Kessler-Harris 2009, 626.

${ }^{25}$ Quataert and Wheeler 2012, 12.

${ }^{26}$ Ware 2010, 417. 
This, among other things, Ware argues, distinguishes feminist biography 'from a biography of a female subject that does not employ feminist analysis'. ${ }^{27}$ Gender is a basic concept in my research on Sigríður's life and letters. She was restricted by gendered notions on the role of men and women in society, and I will reflect on the boundaries of public and private in her life. Sigríður and her female contemporaries did not have equal educational opportunities to men and they did not participate (officially) in public affairs. While Sigrídur lived, there were almost no prospects for women in the rural society of Iceland other than to marry or to work as housemaids. ${ }^{28}$

However, just as the traditional male narrative of biography does not suit most women's lives, the emphasis of feminist biography on public and private, on obstacles that needed to be overcome, i.e., the idea that women were consciously fighting or criticising their status in society, does not fit all women either. Historical narratives and experiences vary and they are situated in time and space and need to be translated or adapted to their local/regional context. My point is that being a young woman, a housewife and a widow in rural nineteenth-century Iceland was different from the urbanised lives of learned women in industrialised and urbanised countries of Europe. Trying to frame Sigríður's life into the same narratives or theorisation as for nineteenth-century feminists, literate women or women travellers, in other words pioneers or thinkers, would be wrong. ${ }^{29}$

${ }^{27}$ Ware 2010, 417.

${ }^{28}$ Halldórsdóttir 2011; Halldórsdóttir 2008, 44-62

${ }^{29}$ See for instance the Danish-Icelandic Benedicte Arnesen-Kall in her two volume account of her travel/visit to Iceland in 1867: Arnesen-Kall 1867, 1871. Furthermore, I discuss the discrepancies of local/national history and 'European' women's and gender history in Halldórsdóttir, 'Beyond the Centre.' (forthcoming). 


\section{Biographies of women in Iceland}

Biography is a popular genre in Iceland and has been for a long time. This includes historical biographies, autobiographies and various types of memoir books. It has been argued that until the late twentieth century and early twenty-first century, these were characterised by the glorification of the protagonist, even being hagiographic in style, and analytically limited. This applies to historical biographies written by professional historians and amateur historians alike. ${ }^{30}$ These have mainly been biographies of men.

Historical biographies on individual women did not emerge until the 1980s ${ }^{31}$ It is, however, interesting that in the 1940s and the early 1950s several of the most successful female writers and autobiographers addressed the lives of their foremothers and other forgotten women of the past in their own memoirs and/or autobiographies. Thus, they wrote biographies within their own autobiographies, as often is the case with autobiographical writing. ${ }^{32}$ Guðbjörg Jónsdóttir, for instance, asked provocatively in 1943 who could tell 'whether these old forgotten women did not have a history as remarkable and entertaining as some men, whom so much is written about, mostly because they were rich'. ${ }^{33}$ This was an obvious reaction to the emerging publication of books on remarkable men during this era, a publication that went hand in hand with the construction of the nation state and independence of Iceland (from Denmark) in 1944. ${ }^{34}$

${ }^{30}$ On this see: Halldórsdóttir 2013, 80-115. Furthermore, several academics answered the question 'What is Biography' in the historical journal Saga in 2011: 'Hvað er ævisaga?’, Saga 49:2 (2011). Also Sigurður Gylfi Magnússon’s two volume on life writing (autobiography, memoirs, biography): Magnússon $2004,2005$.

31 The publication of women's autobiograhies (as books) started in the 1920s and other types of memoirs and interview books soon followed and have continued ever since. The historical biography, dealing with a dead person, her life, deeds and historical context, is another matter.

${ }^{32}$ Guðmundsdóttir 2003, 184.

33 Jónsdóttir 1943, 34.

${ }^{34}$ Halldórsdóttir 2013. 
Furthermore, two interesting collective biographies about 'heroines' were published by female writers around 1950. Both authors wanted to highlight women's lives in nineteenth and early twentieth century Iceland. In 1948, Guðrún Björnsdóttir published Íslenskar kvenhetjur [Icelandic Heroines], a collection of short biographies on women who Björnsdóttir considered worthy of being called heroines, not because of heroic acts but because of their life's work. She believed that 'women were still not appreciated in public position or work, it is not enough that they do as well as men, - they must be outstanding. ${ }^{35}$ When Merkar konur [Remarkable Women] by Elínborg Lárusdóttir was published in 1954, the women's rights activist and writer Aðalbjörg Sigurðardóttir wrote in a review that it was 'invigorating' to have a book containing biographies of women who had lived varied lives. In particular because 'most books of this kind are about men, their work and achievements, women being completely additional'. ${ }^{36}$ The lives of women in Iceland continued to be gathered into collective biographies for years to come. ${ }^{37}$

I believe this demonstrates how constrained historians and writers in Iceland were by ideas of worthiness - and gender. Women, and their lives, were seen as perfect protagonists for collective biographies that portrayed certain periods of time or processes, or the ideals of femininity and female piety and compassion. They were not, however, suitable for a biography of their own. As Backscheider argues, 'men are supposed to be individuals and women are supposed to be women'. Women are,

${ }^{35}$ Björnsdóttir 1948, 145

${ }^{36}$ Sigurðardóttir 1954, 28.

${ }^{37}$ It should be reiterated that I am referring to historical biographies or biographical writing, not autobiographies or memoirs that were either written by the protagonist herself or a writer. Of collective biographies published I wish to mention the series My Mother (Módir min) that started in 1949, dedicated to loving and compassionate mothers. A year later the series My Father (Fadir minn) started and continued into My Father, the priest; My Father, the farmer etc. For women's lives it was My Mother, the housewife. These books were published and edited by men. Also Guðrún P. Helgadóttir's collective biographies on female poets and writers in the earlier ages: Skáldkonur fyrri alda I-II, 1961-1963. And Björg Einarsdóttir's three volume, Úr avi og starfi islenskra kvenna I-III, 1984-1986 (The life and work of Icelandic Women), consisting of 49 biographical chapters on 19th and 20 th century women pioneers - "women worthies". 
she continues, defined differently and 'to be worthy subjects of biographies, [women] must marry into, fall into, or fashion a worthwhile role in life. ${ }^{38}$

Now, in the 2010s, historical biographies about Icelandic women who had 'a worthwhile role in life' are still a small minority within the genre of biography. In 1988, the actress Bríet Héðinsdóttir published the biography of her grandmother, Bríet Bjarnhéðinsdóttir (18561940), the forerunner of women's rights in Iceland. Strangely this was (and is) the only full-length biography written about this grand woman of Icelandic history. The book is neither typical biography nor academic in the traditional sense, but it is the first historical full-length biography of a woman in Iceland. ${ }^{39}$

However, the turning point for feminist and indeed historical biography came in 2001 when the anthropologist Sigríður Dúna Kristmundsdóttir published her biography of Björg C. Porláksson (1871-1934), the first Icelandic woman to hold a PhD (Sorbonne 1926). Kristmundsdóttir grounded her research on feminist theories and ideologies, but also made use of her own discipline, anthropology, in particular "participant observation", where the observer becomes part of the society she is exploring. ${ }^{40}$ Furthermore, Kristmundsdóttir acknowledged the sensitive relationship (even identification) between the biographer and her subject, a relationship that affects the research, interpretation and narration even though the subject is long dead. ${ }^{41}$ In other respects, Kristmundsdóttir's narrative followed traditional chronological order. The connecting theme was how the protagonist, as a woman, reacted to the restrictions of society, how she managed to overcome those restrictions - and the reaction of society. The biography of Björg C. Porláksson thus fits with the emphasis of feminist biography as discussed by Barbara Caine and explained by Susan Ware above. ${ }^{42}$

${ }^{38}$ Backscheider 1999, 141-144.

${ }^{39}$ Héðinsdóttir 1988. As a grandchild Héðinsdóttir takes a personal stance and reflects on her grandmother's life and deeds in a different way than a historian would allow herself to do.

${ }^{40}$ Kristmundsdóttir 2001; Kristmundsdóttir 2006.

${ }^{41}$ Compare to Lepore 2001, 129-144.

${ }^{42}$ Caine 2010, 105-111; Ware 2010. 
Most of the historical biographies of women that have followed in Iceland are either about women who lived exceptional lives, and/or were pioneers, or those who were linked (as wives or daughters) to well-known men in Icelandic history. As such, the landscape of feminist biographies in Iceland does not offer any frames of narration for the life of Sigrídur Pálsdóttir.

\section{Legitimate ways of writing an ordinary life}

It is not offered by international feminist biography either. In fact, there seems to be three main trajectories or acceptable ways of writing a biography of an ordinary woman.

First, there are those who are defined as ordinary, but who were, nevertheless, active within the women's movement, in philanthropy and politics, or as forgotten artists or writers. They may not have been in the forefront, but their activity in the public sphere (or the semipublic) makes their life meaningful and connects them to the accepted historical narrative. The biography of Björg C. Porláksson, and indeed the majority of the very few Icelandic historical biographies on women, would fall within this category. She was a pioneer and a well-known name among her contemporaries and later among women's historians, although less so generally. ${ }^{43}$ 'There is no denying that Björg was a remarkable woman who deserved a biography, such were her achievements', an Icelandic (male) historian wrote about this biography ${ }^{44}$ I have myself used words such as 'remarkable' and 'deserve' when speaking and writing about women, probably because these words validate the individual as a research topic. It is, however, this kind of validation that I am questioning now. Who is 'remarkable' and who 'deserves'?

Second, there are women who broke the rules of society, lived exceptional or marginal lives and are, as such, interesting as research topics. ${ }^{45}$

${ }^{43}$ Kristmundsdóttir 2001.

${ }^{44}$ Magnússon 2004, 98.

${ }^{45}$ For instance the two historical biographies by anthropologist Björnsdóttir (2004, 2009). 
The exceptional ones have frequently been the subjects of microhistorical studies. However, as Caine argues, microhistorians rarely define their work as biographical but rather as 'histories', mainly because they use the life of an individual to illuminate the structures and processes of society. Thus, the protagonist is not necessarily in the forefront. ${ }^{46}$ Needless to say, not only exceptional people are the subjects of microhistory but also individuals who left traces of their lives, such as diaries, letters, memoirs etc. Detailed study of these traces sheds light on agency and social structures - and individual lives. ${ }^{47}$ Sigríður Pálsdóttir has, for instance, been the subject of microhistorical study where her life as a priest's widow (twice) was explored and used to reflect on the status and rights of priests' widows in nineteenth-century Iceland. ${ }^{48}$ My work is influenced by microhistory and its theorisation, but I do not find the frame of narration, or its emphasis, suitable for the life story I want to write.

The third trajectory is represented by ordinary women whose lives merge together with those of other women and become collective biography. ${ }^{49}$ Several lives can be used to construct one narrative that illuminates the lives of women during a certain era, or of a particular social group, as family, friends etc. It can also consist of separate biographical chapters that together form a coherent and collective picture of social changes, for instance, the construction of, and resistance to, gender roles through generations and different experiences in time and space. As Caine points out, collective biography does indeed serve 'to remove the "exceptional" framework from the study of women's lives'.50 Sigrídur Pálsdóttir's life, woven together with the lives of her mother, grandmother, sister, daughters and nieces, who all left evidence behind, would be almost perfect for such work. It would be the history of social change and the status and role of women from the late eighteenth cen-

\footnotetext{
${ }^{46}$ Caine 2010, 24, 112-113. Also Lepore 2001; Magnússon and Szijártó 2013.

${ }^{47}$ See e.g. recent study into the life of an eighteenth-century Icelandic female farm labourer: Hallgrímsdóttir 2013a; Hallgrímsdóttir 2013b, 209-214.

${ }^{48}$ Helgadóttir 1998, 89-111.

${ }^{49}$ Caine 2010, 65.

${ }^{50}$ Caine 1994, 252.
} 
tury until the turn of the twentieth century. That would not, however, be Sigríður's life story.

This said, Sigrídur's story cannot be told or written in isolation, as if she lived her life without interaction with other people. Furthermore, using only her letters, her own words in her biography would mean an incoherent, and even incomprehensible narrative, because there are gaps and silences in her correspondence. After all, what do 250 letters dispersed over 54 years really tell us about a life? Virginia Woolf famously asked, when writing the biography of her friend Roger Fry: 'How can one make a life out of six cardboard boxes full of tailor's bills, love letters and old picture postcards?'51 This is the challenge of every biographer and historian - how to interpret and represent a life that was lived. When working on a life such as Sigríður's, I find it vital not to lose sight of her personal life within the big stories.

\section{New histories}

Notwithstanding my feminist perspective and my willingness to write the life of an ordinary woman, I have struggled with the need to justify my choice; as if Sigríður Pálsdóttir's life and the evidence she left behind is not enough.

These reflections were partly evoked by some of the criticism that the biography Póra biskups (2010), by historian Sigrún Pálsdóttir, received in $2010.5^{52} \mathrm{~A}$ criticism that I argue is rooted in old-fashioned notions of biography. The protagonist, Póra Pétursdóttir, was born into a wealthy family in 1847 and belonged to the small elite of Icelandic officials. She received an excellent education by Icelandic standards and travelled abroad. She met officials and nobility in England and Denmark, including King Christian IX. She took part in philanthropic work (a founding member of the first philanthropic society in Reykjavík), established a drawing school and published (along with her cousin) a book on

${ }^{51}$ Citation from Caine 2010, 90.

52 Pálsdóttir 2010. 
embroidery. Póra married the natural scientist Porvaldur Thoroddsen and finally settled in Copenhagen. She and her husband left behind a vast collection of correspondence, diaries and other sources.

The biography focuses on how Póra expressed herself in her letters and diary - a connecting theme is her search for a suitable husband. Although praised, the biography was also criticised (mainly by male critics) for not discussing fully enough Póra's well-documented part in women's philanthropy, not appreciating her as an artist (painter) and not discussing thoroughly some of the wealthy men in the family. This is exactly the frame of narration the biographer Sigrún Pálsdóttir wanted to avoid: the grand narratives of history in general, and of women's and gender history, where women such as Póra are legitimate subjects of research because of their philanthropic and pioneering work. ${ }^{53}$ Writing about nineteenth-century women has generally been justified by emphasising their work in the semi-public (or women's rights) realm or even because of their relation to great men.

There are, however, many ways to write a life. It is 'an artificial construct', as Hermione Lee argues, and we cannot write everything we know but have to shape and select what to use and how. ${ }^{54}$ And, as Cavarero argued, and as cited in the beginning, no two lives are the same.

Therefore, what narrative is best suited to Sigríður Pálsdóttir's life? The answer is to follow the letters, let them, in all their simplicity and ordinariness, direct the way, that is, as far as their fragmented narration allows. From my standpoint, Sigríður's letters are fascinating documentation of a life as it passes by ${ }^{55}$, and enable me to explore her life 'as it happened not as it turned out.'.5 'As it happened' has been used to explore and unfold social change or a 'process of social becoming ${ }^{57}$, to

${ }^{53}$ Pálsdóttir 2001, 251-259; Pálsdóttir 2012, 113-128.

${ }^{54}$ Lee 2009, 122.

${ }^{55}$ Halldórsdóttir 2014.

${ }^{56}$ Mark and Atmore, quoted by Stanley 2013, 59.

${ }^{57}$ Stanley 2013, 59. On 'life as it happened' see also: Whites Writing Whiteness (2014), 'Getting a handle on South African family archive collections', Whites Writing Whiteness http://www.whiteswritingwhiteness.ed.ac.uk/ project-overview/getting-a-handle/, in particular paragraph 4. Read 28.8. 2014. 
understand how ideologies or social structures developed. I believe this is also a suitable approach for exploring and writing the life of Sigrídur. After all, I am interested in the 'ordinariness' of her letters and her life as it went by, not in what she 'achieved'..$^{8}$

The framework of the 'new history from below' is also helpful for lives such as Sigríður's. Just as the historical biography tended to represent ordinary lives, in particular those of women, as collective history and experience, the 'old' history from below generally studied ordinary people and represented it as a group, en masse. In recent years, there has been a turn to the 'new' history from below where ordinary people, their lives and everyday practices, are explored on an individual level, for instance by using letters and correspondences. Historian Martyn Lyons argues in his book on the writing culture of ordinary people in Europe that 'the new history from below values the study of the individual experience rather than of collective activism'.59 It is from this perspective I wish to view Sigríður's life and experiences.

Furthermore, American biographer Carl Rollyson has criticised the claim for historical representativity in biographies because 'what makes biography, at its core, important is that the story of that individual's life is of intrinsic, not merely historical, interest'. In his view, it is the 'person in his or her personhood' that should be the focal point of the biographer. Rollyson argues that 'writing a biography by strict criteria of what is important in an historical sense is dehumanizing. ${ }^{60}$

I find Sigríður Pálsdóttir important 'all by herself', and by representing her and her ordinary life and writings, I endeavour for her biography to break up the hegemonic and gendered ideas of the history of Iceland and biographical writing. She is represented as an individual and not as a representative or symbol of a particular group of women or of women in general. In that way, the grand narratives of history (both in general and women's history) will not take her life over. It will be contextualised, but still the narrative centres around her letters and her ordinary life and work. It will be a biography of her own.

\footnotetext{
${ }^{58}$ On the ordinariness of letter writing see e.g. Lyons 2014, 14, 248.

${ }^{59}$ Lyons 2014; Lyons 2013, 14-29.

${ }^{60}$ Rollyson 2013, 395.
} 


\section{Bibliography}

\section{Archive material}

National and University Library of Iceland, Department of Manuscripts (NULI) Lbs 2409-2415 4to. Páll Pálsson's archive. Sigríður Pálsdóttir's letters are in Lbs 2413 a 4 to.

\section{Literature}

AHR Roundtable. Historians and Biography. American Historical Review. 114:3 (2009), 573-661.

Alpern S. et al. (eds): The Challenges of Feminist Biography. Writing the Lives of Modern American Women. University of Illinois Press, Urbana and Chicago 1992.

Arnesen-Kall, Benedicte: Smaaskizzer fra en Islandsrejse i Sommeren 1867. Andr. Fred. Høst, København 1869.

Arnesen-Kall, Benedicte: Smaaskizzer fra en Islandsrejse i Sommeren 1867. Anden Deel: Fra nedrejsen. Andr. Fred. Høst, København 1871.

Backscheider, Paula R.: Reflections on Biography. Oxford University Press, Oxford 1999.

Björnsdóttir, Guðrún: Íslenzkar kvenhetjur. Bókfellsútgáfan, Reykjavík 1948.

Björnsdóttir, Inga Dóra: Kona priggja eyja: Ævisaga Ásu Guðmundsdóttur Wright. Mál og menning, Reykjavík 2009.

Björnsdóttir, Inga Dóra: Ólöf eskimói: Evisaga islensks dvergs i Vesturheimi. Mál og menning, Reykjavík 2004.

Caine, Barbara: Feminist Biography and Feminist History. Women's History Review. 3:2 (1994), 247-261.

Caine, Barbara: Biography and History. Palgrave Macmillan, London 2010.

Cavarero, Adriana: Relating Narratives. Storytelling and selfhood. Translated and with introduction by Paul A. Kottman. Routledge, London 2000.

Dowd, Michelle M. and Eckerle, Julie A. (eds): Genre and Women's Life Writing in Early Modern England. Ashgate, Aldershot 2007.

Earle, Rebecca (ed.): Epistolary Selves: letters and letter-writes, 1600-1945. Ashgate, Aldershot 1999.

Einarsdóttir, Björg: Úr avi og starfi islenskra kvenna I-III. Bókrún, Reykjavík 1984-1986.

Guðmundsdóttir, Gunnpórunn: Borderlines. Autobiography and Fiction in Postmodern Life Writing. Rodopi, Amsterdam 2003.

Halldórsdóttir, Erla Hulda: Beyond the Centre. Women in nineteenth century Iceland and the grand narratives of European women's and gender history. [Forthcoming]

Halldórsdóttir, Erla Hulda: Do Not Let Anyone See This Ugly Scrawling: Literacy Practices and the Women's Household at Hallfreðarstaðir 1817-1829. Life Writing. 12:3 (2015), 289-308.

Halldórsdóttir, Erla: The unforeseeable narrative. On turning a lifelong correspondence into a life story. A paper presented at the international conference Writing women's lives: Autobiography, life narratives, myths and historiography, Yeditepe University, Istanbul 19-20 April 2014.

Halldórsdóttir, Erla Hulda: Táknmynd eða einstaklingur? Kynjað sjónarhorn sögunnar og ævi Sigríðar Pálsdóttur. Skirnir. 187 (2013), 80-115. 
Halldórsdóttir, Erla Hulda: Earning one's living. Debates on femininity in Iceland in the 1880s. Rhetoric of work. Eds Dimitra Lambropoulou, Yannis Yannitsiotis and Carla Salvaterra. Plus-Pisa University Press, Pisa 2008, 44-62.

Halldórsdóttir, Erla Hulda: Nútímans konur. Menntun kvenna og mótun kyngervis á Íslandi 1850-1903. Sagnfræðistofnun/Háskólaútgáfan/RIKK, Reykjavík 2011.

Hallgrímsdóttir, Guðný: Material without value? The recollections of Guðrún Ketilsdóttir. White field, black seeds. Nordic literacy practices in the long nineteenth century. Eds. Anna Kuismin and M.J. Driscoll. SKS, Helsinki 2013, 134-145.

Hallgrímsdóttir, Guðný: Sagan af Guðrúnu Ketilsdóttur. Einsögurannsókn á avi 18. aldar vinnukonu. Háskólaútgáfan, Reykjavík 2013.

Hamilton, Nigel: Biography: A Brief History. Harvard University Press, Cambridge, Mass. 2009.

Heilburn, Carolyn: Writing a Woman's Life. Ballantine Books, New York 1988.

Helgadóttir, Guðrún P.: Skáldkonur fyrri alda I-II. Reykjavík 1961-1963.

Helgadóttir, Kristrún Halla: Hagir prestsekkna. Einsagan - ólikar leiðir. Átta ritgerðir og eitt myndlistarverk. Eds. Erla Hulda Halldórsdóttir and Siguður Gylfi Magnússon. Háskólaútgáfan, Reykjavík 1998, 89-111.

Héðinsdóttir, Brít: Strá i hreiððð. Bók um Brieti Bjarnhéðinsdóttur byggðá bréfum hennar. Svart á hvítu, Reykjavík 1988.

Jónsdóttir, Guðbjörg: Gamlar gleður: Pettir úr daglegu lifi à Ströndum à siðari bluta 19. aldar. Ísafold, Reykjavík 1943.

Kenyon, Olga: 800 years of women's letters. Foreword by P.D. James. Sutton Publishing, Thrupp (1993) 2003.

Kessler-Harris, Alice: Why Biography? American Historical Review. 14:3 (2009), 625-630.

Kristmundsdóttir, Sigríður Dúna: Far from the Trobriads? Biography as a field. Locating the Field. Space, place and context in anthropology. Eds. S. Coleman and P. Collins. Berg, Oxford 2006, 163-177.

Kristmundsdóttir, Sigriłur Dúna: Björg. Evisaga Bjargar C. Porláksson. JPV-útgáfa, Reykjavík 2001.

Lee, Hermoine: Biography: A Very Short Introduction. Oxford University Press, Oxford 2009.

Lepore, Jill: Historians Who Love Too Much: Reflections on Microhistory and Biography. The Journal of American History. 88:1 (2001), 129-144.

Lyons, Martyn: A New History from Below? The Writing Culture of European Peasants, c. 1850 - c. 1920. White Field, Black Seeds. Nordic Literacy Practices in the Long Nineteenth Century. Eds. Anna Kuismin and M.J. Driscoll. SKS, Helsinki 2013, 14-29.

Lyons, Martyn: The Writing Culture of Ordinary People in Europe, c. 1860-1920. Cambridge University Press, Cambridge 2014.

Magnússon, Sigurður Gylfi and Szijártó, István M.: What is Microhistory? Theory and Practice. Routledge, London 2013.

Magnússon, Sigurður Gylfi: Fortiððardraumar: Sjálfsbókmenntir á Íslandi. Háskólaútgáfan, Reykjavík 2004.

Magnússon, Sigurður Gylfi: Sjálfssögur: Minni, minningar og saga. Háskólaútgáfan, Reykjavík 2004.

Margadant, Jo Burr (ed): The New Biography: Performing Femininity in Nineteenth-Century France. University of California Press, Berkeley 2000.

Pálsdóttir, Sigrún: Hreyfimynd með hljóði frá 19. öld eftir Póru Pétursdóttur. Saga 50:2 (2012), 113-128.

Pálsdóttir, Sigrún: Sagan um Póru biskups. Kvennaslódir: Rit til heiðurs Sigriðði Th. Erlendsdóttur sagnfraðingi. Ed. Anna Agnarsdóttir. Kvennasögusafn Íslands, Reykjavík 2001, 251-259. 
Pálsdóttir, Sigrún: Póra biskups og raunir íslenskrar embattismannastéttar. JPV-útgáfa, Reykjavík 2010.

Possing, Birgitte: Genren med de mange liv: Et kritisk blik på biografien. Det kritiske blik. Eds. N. Bredsdorff and N.F. Christiansen. Tiderne Skifter, København 2005, 143-163.

Quataert, Jean and Wheeler, L. A: Individual Lives: Windows on Women's History. Journal of Women's History. 24:3 (2012), 7-12.

Rollyson, Carl: Reviews. Biography. 36:2 (Spring 2013), 392-395.

Saga 49:2 (2011). Eleven scholars answer the question: What is Biography, 9-52.

Sigurðardóttir, Aðalbjörg: Merkar konur — ný bók Elínborgar Lárusdóttur. Morgunblaðið 22 December 1954 (II), 28.

Stanley, Liz: Whites Writing: Letters and Documents of Life in a QLR Project. Documents of Life Revisited. Narrative and Biographical Methodology for 21st Century Critical Humanism. Ed. Liz Stanley. Ashgate, Aldershot 2013, 3-16.

Ware, Susan: Writing Women's Lives: One Historian's Perspective. Journal of Interdisciplinary History. 40:3 (2010), 413-435.

Fjóó́lfur 28 April 1871. 


\title{
Group biography as an approach to studying manhood and religion in late nineteenth-century Finland
}

\author{
Antti Harmainen
}

The interest in the biographical approach that has recently inspired many historians has also managed to intensify the theoretical discussion on collective biographies. There has been a demand for this kind of opening: researchers who have worked on the field of collective biographical approaches have pointed out that these viewpoints have often remained somewhat latent in methodological terms. Collective biographical procedures are constantly used in historiographical studies, but the literature that would explicate these procedures and clarify on their theoretical basis is still quite narrow. ${ }^{1}$ Key theorists in the field, such as British historian Katharine Keats-Rohan, have noted that the small body of literature has enabled loose demarcations between different biographical concepts on a scale that can bewilder the unaccustomed reader. Australian historian Barbara Caine has made parallel remarks. According to Caine, one of the most prominent problems in contemporary collective biography is the variability of the field. The concept of collective biography has been functioning as an umbrella term for many approaches that have only a vague common denominator in theoretical sense. Collective biography has been used to refer to biographical dictio-

\footnotetext{
${ }^{1}$ Caine 2010, 47-48; Hakosalo 2014, 45-61; Possing 2014, 62-68.
} 
naries as well as to a multitude of historiographical studies dealing with networks, groups or intellectual collectives. ${ }^{2}$

In this chapter, my intention is to scrutinise the spectrum of collective biographies by focusing on the concept of group biography. Since its emergence in the 1970s, this approach has gained an increasing amount of coverage in the field of historiographical studies. ${ }^{3}$ The chapter will focus on theoretical definitions and trajectories behind the group biographical view and link them to the current discussion, taking into consideration the status of biographical and group biographical approaches as tools for historians. I will elaborate on the theoretical framework mainly in relation to categories of gender and religion. My stance towards the category of gender is mainly based on a foundation of the concept of manhood, which in recent gender historical discourse has referred to a constructive way of analysing male identities and their historically layered constitution. ${ }^{4}$ In the sections that consider the relationship between religion and group biographical studies, my aim is to sketch out a theoretical solution that would support critical reading on the masculine and clerical image of Western religiousness - a concept that has received plenty of critique in the fields of contemporary religious studies, feminist theology and the history of religion. ${ }^{5}$

The practical examples in this chapter are related to my ongoing work on my doctoral thesis, which will focus on esoteric movements and ideas in Finland at the turn of the twentieth century and their reception in the network of educated-class Finnish men. My work is connected to the wider field of academic study that has gained recognition during the last decade. Historians, as well as researchers from religious studies and social sciences, have stressed the cultural significance of the tradition of so-called Western esotericism. This concept has been operating as a constitutive term for a mass of ideas and phenomena ranging from NeoPlatonist philosophy to Renaissance Paracelsianism and further on - as in my case - to modern Spiritualist movement and modern Theosophy

\footnotetext{
${ }^{2}$ Caine 2010, 47. See also Keats-Rohan 2007, 139-140.

${ }^{3}$ Caine 2010, 61-62.

${ }^{4}$ See Ahlbäck 2010, 28-44.

${ }^{5}$ See Utriainen et al. 2014, 1.
} 
at the turn of the twentieth century. ${ }^{6}$ My purpose here is also to ponder the possibilities of group biography as an optional methodological solution in studying the complex interaction between modern Western esotericism and modern religiousness. By using my thesis composition as a demonstrative case, I will reflect on how the concept of esotericism and also the wider field of fin de siècle religion can be comprehended when seen through the theoretical lens of group biography.

\section{Theoretical background and contemporary applications}

The emergence of group biography has often been defined in a close-knit relationship with the process of establishing feminist theory. According to Barbara Caine, group biography was originally seen as a means of creating a critical view of the profound cultural composition that linked female subjectivity with domestic and private spheres. This kind of biased setting also characterised the wider field of biographical studies. During the eighteenth and nineteenth centuries, women were accepted as biographical protagonists mostly under a gendered set of conditions: the ones who were taken into the biographical canon were represented as model examples of 'feminine qualities' whose attachment to domestic life often marginalised their public work and aspirations. The connection between femininity and domesticity had an impact also in the concrete process of creating biographies. For example in comparison with academic historiography, biographical study was defined as having inferior scientific value, and therefore it was seen as a suitable field for female authors. Caine states that most of the early group biographies in the 1970s were actively moulding this gendered bias as their key motif. Group biographies were still mostly written by women and focused on women and domesticity, but the basic reading model had by this time radically changed due to the influence of ascendant feminist theory as well as the linguistic turn in the late 1960s. An important parallel was the emergence of the so-called new histories that were also turning the

\footnotetext{
${ }^{6}$ As for general presentation, see Hanegraaff and Pijnenburg 2009.
} 
historiographical focus on the self-reflecting and self-conducting individual. ${ }^{7}$

The theoretical turning point of the late 1960s and early 1970s enabled the regularization of the long-term process which had produced the first biographical attempts to shed light on the female subjects in a context that transcended the domestic and private spheres. The rise of group biography - as part of the wider theoretical turn - produced a multitude of studies in the 1970s and 1980s in which female protagonists were interpreted through their agency. Their aspirations and cultural expressions were then critically analysed as means to adapt to the surrounding social environment and to negotiate individual space and new ways of acting among confining structures. Caine has proposed that this development is one of the key trajectories behind contemporary biographical study and its interest in individuals that operate in one set or another of biased circumstances. Caine states that these 'new biographical subjects' of twenty-first century historiography have had considerably varying backgrounds; from female individuals, the target range has expanded to cover - in Caine's words - 'political or social dissidents, petty criminals, humble workers, slaves and many others who had little impact in the world around them'. In this multitude of subjects, an integrative theoretical factor has been a sensitivity towards the particular and personal - often tensioned - comprehensions on surrounding reality. ${ }^{8}$

The idea of new biographical subject brings together several theoretical trajectories in a productive way. In my case, this particular framework has been helpful in organizing the complex relationship between the individual and surrounding contexts as well as operationalizing the analytical categories that are relevant in my study. In a sense, I have interpreted the concept of the new biographical subject as a basic unit for contemporary group biographical analysis. By expanding the focus from individual agency to cover groups or networks, it becomes possible to observe the structural dynamics of the past societies while also maintaining the idea of individual lives that stirred different categories and

\footnotetext{
${ }^{7}$ Caine 2010, 54-56, 61-65, 105-116.

${ }^{8}$ Caine 2010, 61-65, 111-116; Florin 2014, 28-29.
} 
levels of private and public into relational and organic reality. I have utilised this dynamic, especially in my attempts to put the category of religion into play. For me, one of the most compelling features in the group biographical approach is the resonance it creates with the recent theoretical discussion in religious studies and the history of religion.

Group biography seems to be particularly compatible with the ideas presented in the field of gender-sensitive religious study. The recent theoretical discussion has emphasised the importance of re-evaluating the 'master narrative' of Western religious life - a picture of religion that is based on elite and often masculine premises such as church leaders and official religious doctrines. ${ }^{10}$ Group biographical theory has helped me in building a similar critical composition in my own studies. The approach has encouraged me to create a synthesis between individual agency and the concept of religion: it has led me to assume that, despite the fact that public religious life in late nineteenth-century Finland was in many ways culturally biased, contemporary male individuals also lived and negotiated religion in private in a way that could transcend the limits of public policies. This kind of angle can produce fresh interpretations of male religiousness and supplement - and even challenge - the established conception, which has emphasised the polarity between governmental Christianity and modern secularism empowered by science and technology.

One of the most obvious features in group biography is its aim to produce qualitative analysis on different types of groups and their internal relations. ${ }^{11}$ Although this kind of conclusion may sound self-evident, it contains heuristic potential which can be applied to the concepts of gender and masculinity. Recent biographical research has brought forth the idea of the relational or networked individual. This concept has been seen as a critical option in autonomous subjectivity, which has operated as an ideal constitution of Western individualism in uncountable biographical writings, especially in the ones that concentrate on prominent male characters. According to Finnish historian Maarit Leskelä-Kärki, the challenging idea of the collectively produced relational subject is

\footnotetext{
9 See Roberts 2002, 18-19; Englund and Kåreland 2008, 220-227.

${ }^{10}$ Utriainen et al. 2014, 1-2.

${ }^{11}$ Hakosalo 2014, 53-57.
} 
linked to the feminist identity theory of the 1980s, which had presented a concept of distinct processes that shaped feminine and masculine identities. One starting point of the theory was the assumption of relational femininity, which was seen to be constructed in interactive relationships between individuals. Masculine identity was in turn interpreted as a product of separations and exclusions. In its early stages, the theory was criticised as being essentialist and prone to support the bipolar gender order, but after reinterpretations made in the 1990s, it has been used to create positions that also emphasise the relational character of manhood..$^{12}$ In my methodological apparatus, the idea of group biography is often operating as a critical stance towards the idea of exclusive masculinity. I have treated the approach as a concrete way to deploy male protagonists as well as the concept of manhood within the contexts of relationality and cultural synthesis. In next sections, I will elaborate on the idea of group biography and its use as a tool to reveal how male individuals could also negotiate their identity collectively and by using concepts that blurred the outlines of divided gender order of the late nineteenth century.

\section{Group biography, gender and manhood}

Perhaps one of the most discussed topics in gender historical study has been the establishment of critical vantage points for re-defining the socalled national canons. Dutch historian Maria Grever states that historical culture in Western countries has evoked the fear of plurality in its tendency to maintain the icons of national histories. In this process, one of the most fundamental images has been the one of 'great men', often accompanied by a series of 'classical ideas' that canonised male individuals have carried. ${ }^{13}$ The traditional conception of male genius has been supported by biographical works that have represented their protagonists as autonomous individuals performing exceptional deeds

${ }^{12}$ Leskelä-Kärki 2014, 317-318.

${ }^{13}$ Grever 2009, 45-47. 
that - according to Finnish theologian Olavi Kares in his biography on Martin Luther (published in 1945) - 'cannot be weighed with a scale set for common men'. ${ }^{14}$

In the context of national canons, group biography's deconstructive potential can be seen in its tendency to avoid the artificial and often pedestalizing isolation of target individuals. A critical position can be created by exposing the ideal of the exceptional individual or 'genius' to a cross-light shed by the surrounding social networks. Barbara Caine has listed several recent studies that have utilised this kind of approach to produce an analytical image of recognised men and also to contest the ideals of Western manhood by inspecting the social and cultural layers behind their representations. The group biographical approach has been used to scrutinise a variety of collectives - siblings, families, ideological or political networks and scientific clubs - and to specifically illustrate how personal relationships and backgrounds have sometimes had a significant effect on public masculine identities and policies. ${ }^{15}$

Group biographical interpretations on the ideal of the autonomous male individual can produce a dynamic reading model in relation to the established study of manhood and masculinities. Australian sociologist Raewyn Connell states that the image of self-controlling, rational manhood has come to serve as a Western cultural archetype that has had a strong influence in common discourses as well as in academic study. ${ }^{16}$ Connell's concept of hegemonic masculinity has been a reflection point for a multitude of gender-oriented researchers, but recently a tendency to produce compromising interpretations of the concept of hegemonic or essentialist masculinity has also intensified. The study has shifted its focus to emphasise the manifold character of manhood, the variety of its social and cultural constructions, and affiliations between manhood, gender and other categories that constitute social reality. ${ }^{17}$ This kind of focus can be partly drawn as a parallel with group biographical theory. From the perspective of gender analysis, group biography can guide a

\footnotetext{
${ }^{14}$ Kares 1945, 76-82.

${ }^{15}$ Caine 2010, 63-65.

${ }^{16}$ Connell 2005, passim.

${ }^{17}$ Ahlbäck 2010, 28-44; Aalto 2012, 25-29.
} 
researcher to study male individuals in a framework that dismantles the concept of masculinity as a pre-determined cultural hegemony. The approach can reveal parts of the process in which male subjects simultaneously reproduce and re-shape the definitions of manhood by using both the public and private spheres of their lives and by constantly blending categories such as gender, religion and nationality.

In my ongoing research, I am attempting to process the above-mentioned theoretical framework to match my research composition, which revolves around several male writers whose period of activity ranged from the 1880 s to the 1910 s. One preliminary observation about late nineteenth-century gender dynamics has been that some of the target persons, who were well-known proponents of rebellious fin de siècle individualism in public, also maintained a private discussion that could markedly contradict their public voice or identity. The discussion was usually held within a circle of their closest relatives and friends, and some fragments of it were recorded in sketchbooks, diaries and correspondence. This kind of source material may bring fresh nuances to the picture of late nineteenth-century Finnish intelligentsia, which has often become associated with a gendered assumption of sexual liberalism. Especially the group of young male artists has been seen as an emblem of the 'new' male identity that rejected the traditional authorities and pioneered modern, distinct masculinity by emphasizing individual force and endeavour as main attributes of the modern intellect, emotionality and sexuality. ${ }^{18}$

However, optional ways to organise a gender identity also existed. A good example of a relational stance towards manhood is the process in which Johan Henrik (J. H.) Erkko (1849-1906), one of Finland's most renowned writers in the 1880 s, tried to adapt new concepts in gender and sexuality. Erkko's private discussion with his closest colleagues gives plenty of evidence to suggest that he did not necessarily want to exclude from his perceptions all the elements that were considered to be feminine. It even seems that the gendered concept of femininity contained features that were crucial, in Erkko's view, in creating a morally sustainable modern manhood. In his mid-1880s sketchbooks, Erkko expe-

\footnotetext{
${ }^{18}$ For instance, Nieminen 1951, 19-31. See also Mosse 1985, 48-65.
} 
Group biography as an approach to study manhood and religion

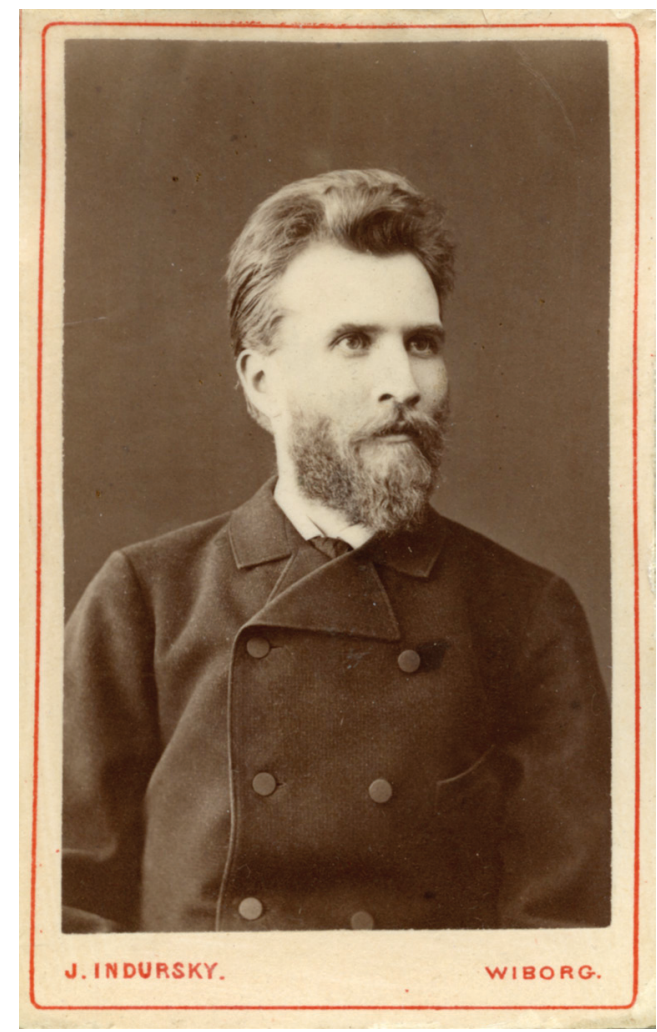

J. H. Erkko. 14.8.1881. (Päivälehden arkisto, Helsinki)

rimented with the idealised concept of femininity: he saw the concept as a chance to filter out some of the negative features that were seen to burden the masculine side of the polarised system. If men could adopt feminine features such as empathy, self-sacrifice and temperance as part of their identity, they might be able to break the contemporary concept of biological determination that was believed to dictate the urge to indulge in sexual conquest, aggression and many other negative features of masculinity. ${ }^{19}$

${ }^{19}$ Harmainen 2014a, 20-24. 
The group biographical setup also enables a scale of comparison that indicates that Erkko was not alone with his experiments. The synthesis between masculine and feminine features raised collective enthusiasm in his network of colleague writers, especially in the latter half of the 1880s. Erkko's thinking was strikingly similar to that of a female colleague, Minna Canth (1844-1897), who was the most celebrated female author of her time in Finnish literature. Canth saw a parallel concept of idealised femininity as a means to refine manhood by supplementing it with 'gentle emotionality, strict temperance and religion'. ${ }^{20}$ An ideological interaction between the two authors also at least partially motivated Erkko to create his own connection between religion and gender. It is notable that, during this process, Erkko was relatively critical towards the fashionable scientific theories that promoted liberal opinions on male sexuality. He was familiar with renowned writers such as Austrian physician Max Nordau (1849-1923) but could not fully accept their Social Darwinist views on gender relations. Erkko decided to seek more solidarity and a more spiritual solution by taking concepts of Christian theology from modern religious authorities such as Edouard Laboulaye and Eduard von Hartmann and combining them with the ideas presented in the field of modern esotericism. The general motive for Erkko was that, by processing the feminine and the religious, he was simultaneously building a position that could serve as an optimal constitution for modern manhood. ${ }^{21}$

\section{Group biography and the many-sided concept of fin de siécle religion}

One of the essential groups that I intend to analyse in my research will be centred around J. H. Erkko and his younger brothers Eero Erkko (1860-1927) and Elias Erkko (1863-1888), all of whom became

${ }^{20}$ Minna Canthin kirjeet [Minna Canth's letters] 1973, 87.

${ }^{21}$ Harmainen 2014a, 27-28. Considering the connections between modern religiousness and gender, see Owen 2004, 85-115; Markkola 2006, 223 237; Kinnunen 2014, 70-75. 
somewhat well-known in the cultural milieu of late nineteenth-century Finland. J. H. Erkko had achieved recognition not only through his books, but also from his public criticism of the state church and other institutions he held responsible for generating an atmosphere of conservatism in Finnish society. Eero Erkko was the editor-in-chief of Päivälehti, a newspaper that became one of the leading organs of Finnish political radicalism at the turn of the twentieth century. The youngest brother, Elias, was also a budding author and an art critic seen as a rising talent among the Finnish intelligentsia. The network of the Erkko brothers also included Elias's fiancée, actress Hilda Asp (1862-1891), and her brother Gustaf Asp (1866-1852), who made a career as an architect.

The group of Erkko and Asp siblings has often become connected to two intertwining phenomena that labeled the Finnish cultural life in the late nineteenth century. J. H. Erkko, Elias Erkko and Hilda Asp are sometimes considered members of one epicentre of literary realism in Finland. Seen from this perspective, J. H. Erkko's role was to act as a renowned public spearhead, while Elias and Hilda were operating as atelier critics and a kind of ideological éminence grise. Besides the literal realism, the group was ideologically held together by the Fennoman movement, a political and cultural current that had advocated Finnish language and identity since the early nineteenth century. In the latter half of the nineteenth century, this movement started to intensify its emphasis on nationalistic ideas and brought concepts such as 'the Finnish people' and 'Finnish history' into regular public use. The very same context became a key motive for the Erkko-Asp group: also Eero Erkko and Kustaa Asp were engaged in it and its ideals. When the ideological consensus of the movement shattered in the last decades of the nineteenth century, the Erkko and Asp siblings adapted the ideas promoted particularly by the younger Fennoman generation, who adapted the idea of serving 'the Finnish people' with social, political and cultural radicalism as their epitome. ${ }^{22}$ Many interpretations have described this mission to be partly built on anti-religious ideas and a secular world view brought on by the development of contemporary science. ${ }^{23}$ The

\footnotetext{
22 On the Fennoman movement, see Liikanen 1995, 279-321.

${ }^{23}$ See Nieminen 1951, 19-31, 118-131; Maijala 2014, 312-315.
} 


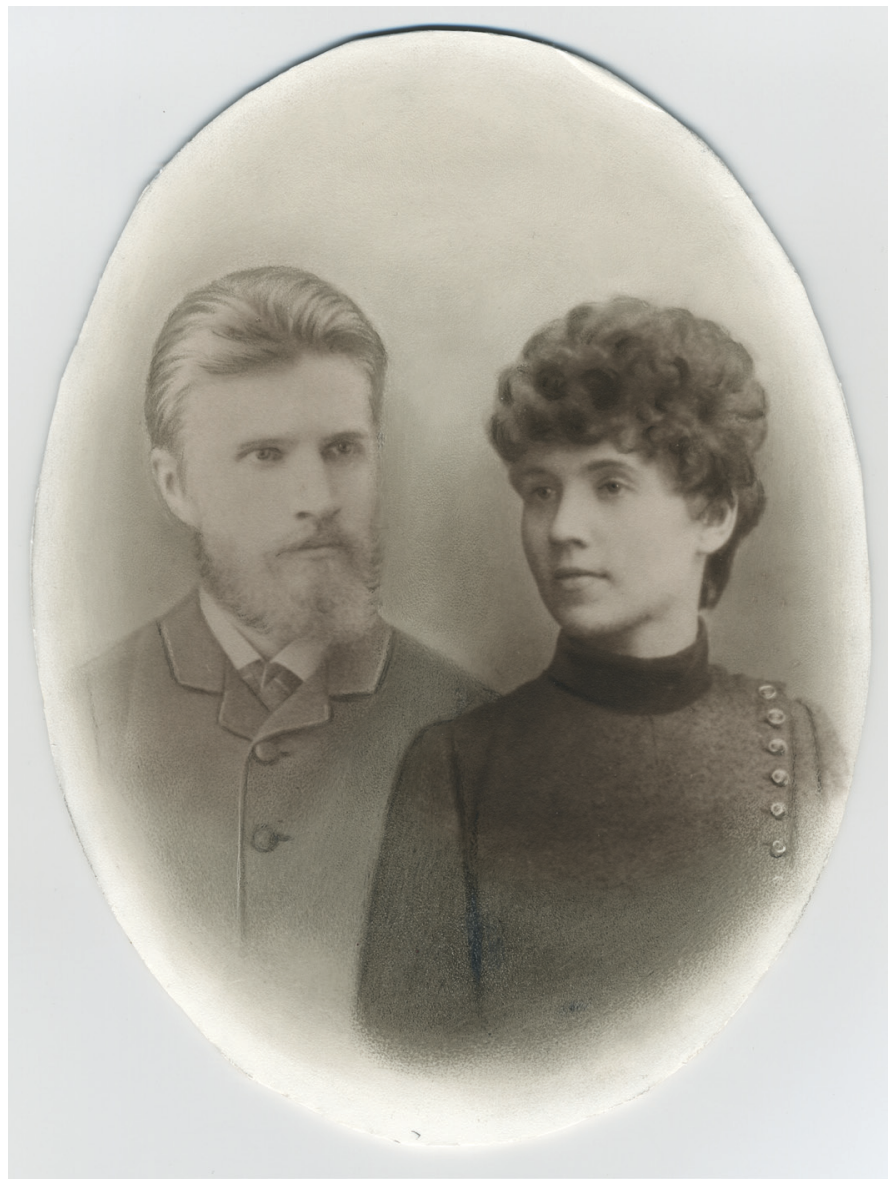

Elias Erkko and Hilda Asp. (Päivälehden arkisto, Helsinki)

dynamics between the Erkko and Asp siblings may, however, suggest that sometimes the character of religious reformism was something far more complex than plain secularism.

An example of group biography in action can be outlined by focusing on the above-mentioned network in the mid-1880s. During that time, radical religious stances started to become public to a degree basically unprecedented in a Finnish context. Newspapers, journals and fic- 
tion began promoting ideas critical of the Lutheran state church and its doctrines. ${ }^{24}$ This revisionist tide did not go unnoticed by the Erkko brothers and their inner circle: J. H. Erkko had written enthusiastic articles about Darwinism as far back as 1881 and continued to explicate his religious mistrust in poetry anthologies. On the basis of Erkko's newspaper articles and other public writing, it would be logical to conclude that the poet was actively disconnecting himself from religiousness and looking for new directions in the field of scientific knowledge. However, Erkko's public conceptions can, again, be contrasted with his private writings. Additionally, this picture can be extended to his network of family members and compared with their writings. In Erkko's case, this creates a kind of double image: religious critique exhibited in public accompanied by religious deliberation taking place within the network. Private discussions with his younger brother considering 'the right comprehension of God and Christ ${ }^{25}$ and many other religious concepts paint an alternative picture that compromises the image of Erkko as an anti-religious poet that prevailed in the public sphere. Based on this, it becomes possible to claim that his intention was not to abandon religion as such, but to negotiate new religious terms that he could accept as his ideological cornerstone in his contemporary circumstances.

The next natural step for a researcher working in the biographical field would be to ask whether there was anything in the lives of the target individuals that would support the essential role of religion as a shared motif. By tracing back the Erkko and Asp family histories, it is relatively easy to determine how prevalent a phenomenon religion was within both families. The Erkko and Asp siblings had their religious roots in Finnish pietism, which apparently served as a unifying element in the background of the group's interactions. It also becomes obvious that, in the climate of late nineteenth-century religious criticism, there was a great deal of personal variance between the conceptions of each of the group members. For example, both J. H. and Elias Erkko were fascinated by Maria Asp - the mother of Asp siblings - and the contemplative Pietist faith she represented. Yet they were just as eager to read

\footnotetext{
${ }^{24}$ Juva 1960, 9-27.

${ }^{25}$ Hilda \& Elias 1984, 24.
} 
contemporary intellectual authorities such as Eduard von Hartmann and Frederick Farrar - and Charles Darwin. ${ }^{26}$

An interesting addition to the religious ensemble of the 1880s was the field of modern Western esotericism, which also caught the attention of the Erkko and Asp siblings. J. H. Erkko became familiar with modern Spiritualist movement and modern Theosophical ideas while traveling in Germany and Austria in 1884-1885. According to historian Corinna Treitel, esoteric and occult movements and ideas were at that time going through a boom in major German and Austrian cities: local newspapers were filled with heated debate considering mediums, Spiritualist phenomena and their scientific authenticity, and several esoteric societies were launching their public activities. ${ }^{27}$

Erkko's sketchbook notes from his traveling years are supporting Treitel's argumentation. The Austro-German scene of esotericism clearly left traces in Erkko's writing and thinking in the 1880's. Perhaps the most notable thing in this ideological connection is that esoteric concepts intertwined thoroughly with the intellectual search that Erkko was doing in the field of gender and sexuality. Between 1884 and 1887 he became fascinated with concepts of reincarnation and karma, which were at the time adapted from Buddhism and Hinduism by both Theosophical and Spiritualist movements and re-interpreted through the languages of Western esotericism and contemporary science. Erkko was using both concepts to create himself a certain kind of 'buffered' sexual identity: ${ }^{28}$ karma and reincarnation provided the means to stretch the borders of Evangelical Lutheran sexual morale, which treated sexual relationships - especially those that happened outside the marital institution - as a sin. Erkko had been anxious by this traditional perception in the 1880 's, until he managed to elaborate new views by using esoteric concepts. Reincarnation and karma were able to transform ideas of sexuality to a mentally more tolerable state. Partly through this synthetic composition, Erkko gained fresh ideological tools to confront the male sexuality and sexual acts - not as an irreversible and fatal sin but

\footnotetext{
${ }^{26}$ Hilda \& Elias 1984, 23-29, 61-62.

27 Treitel 2004, 29-82.

${ }^{28}$ More precise definition of 'buffered identity', see Taylor 2007, 37-42.
} 
as temporary, controllable and atonable breaks in the cosmic rotation of individual striving and spiritual development. ${ }^{29}$

Another visible influence of Western esoteric currents appeared in the correspondence of Erkko and Asp siblings in 1888, when Elias Erkko died due to tuberculosis. After the bereavement, J. H. Erkko and Hilda Asp sought consolation by immersing themselves to the Spiritualist and Theosophical ideas. In this sense, the key function in both movements was to combine scientific and religious concepts and reveal the hidden truths of the universe that were also thought to dictate the borderline between the living and the dead. Especially the correspondence between Hilda Asp and J. H. Erkko reveals an interesting religious ambiguity: both correspondents were highly suspicious, to some extent even explicitly angry and bitter towards Christian faith, theology and perceptions of god and heaven, but yet found it consoling to describe the late Elias Erkko as an anthropomorphic, individual 'soul', which according to their hopes continued its personal existence in the afterlife. They contacted several European mediums, hoping to receive some clear evidence about this spiritual existence. Hence, Spiritualist ideology was functioning as a religious catalyst that knitted empirically oriented views and more traditional Christian concepts together in an intellectually sustainable, 'modern', way without losing the emotionally consoling religious edge. It is descriptive that experiments with Spiritualist mediums raised mixed feelings in many members of the family circle, but nevertheless no one had any serious doubts about accepting the overall idea of afterlife, an individualistic spiritual continuum, which in their perspective was the ultimate common denominator between Evangelical Lutheran Christianity and the late nineteenth-century esotericism manifested by the Spiritualist and Theosophical movements. ${ }^{30}$

This snapshot of the Erkko and Asp siblings and their religious conceptions seems to be compatible with several definitions brought forward in group biographical theory. On the one hand, it emphasises the heuristic potential of the private sphere and private writing. Corres-

\footnotetext{
${ }^{29}$ Thematics in this section is presented completely in Harmainen 2014a. Parallel analysis considering male sexuality and esoteric conceptions see Owen 2004, 186-221; Djurdjevic 2014, 35-73.

${ }^{30}$ Harmainen 2014b, 391-392.
} 
pondence and other personal text sources can offer new insights into the established picture of secular modern manhood. For the Erkko-Asp network, religious knowledge very clearly played a role in the collective process of creating concepts that the group considered to be 'modern'. In addition, this constellation can provide deconstructive angles to religion and gender as fixed categories. By comparing the different religious views inside the group it becomes possible to perceive in a concrete way, how diversely the idea of religion could reveal itself to group members. Religion was not simply synonymous with Christianity; rather, it was a set of options that ranged from one particular branch of Finnish pietism to liberal Lutheran theology and, further, to modern esoteric movements that were clearly able to integrate with many cultural phenomena of the late nineteenth century. ${ }^{31}$ On the other hand, the group dynamics also reveal the flipside of religious revisionism, emphasising the fact that all of the group members had a close-knit relationship with their own religious past, which sometimes seemed to function almost like a rigid family tradition that refused to give in to the modern subject's aspirations. It steered their views in a way that even transcended their level of intellectual reflection and made them end up with very similar interpretations of apparently distinct themes. This was many times the case with their reading of contemporary esotericism: the group was prone to emphasise concepts that resonated with their own religious background.

\section{Conclusions}

American historian Jeanne Boydston presented a fascinating methodological challenge in her article from 2008 entitled 'Gender as a Question of Historical Analysis'. In her conclusions Boydston called for a gender history that would allow 'riffing' and, even more provocatively, would recognise 'the process of riffing as the very heart of the field'. ${ }^{32}$ Boydston

${ }^{31}$ More thoroughly on this thematic, see Owen 2004, 238-259; Stuckrad 2010, passim.; Hanegraaff 2012, 252-277; Asprem 2014, 413-531.

32 Boydston 2008, 579. 
used one of the arch concepts of popular music to lure her colleagues into making heuristic crossings between gender and other categories of analysis. What concerned Boydston was that the use of clinical categories and concepts seemed to work against their original purpose, which - according to Boydston - was to produce an 'ever more nuanced history of power and resistance' that would bring suppressed and invisible past lives into the contemporary spotlight. However, Boydston stated that, without strict criticism, categories of analysis could disturb the pictures of past lives and societies by reading them through mechanisms that were not necessarily relevant in the particular culture being studied. Boydston's challenge was about finding the means to reach the 'relational dynamic' of cultural processes that simultaneously produce and maintain constructions such as 'men' and 'women'. ${ }^{33}$

Swedish historian Christina Florin describes the possibilities of group biography in a way that can provide at least partial answers to Boydston's challenge. According to Florin, the most productive yield of the group biographical approach is the ability to transilluminate conceptual dichotomies and categories. Biographical analysis can illustrate the fragility of analytical abstractions by bringing forth the historical person equipped with social relations, aspirations, emotions, health, education and occupation, and scrutinising the process that binds the individual to the structural framework. ${ }^{34}$ Florin has also emphasised the heuristic potential of mapping the private lives of past individuals. Private sources can reveal how closely connected personal emotions and public statements can be. In the heat of building modern culture at the turn of the twentieth century, it was often unclear what the actual distance was between personal solidarity and political tactics or family relations and occupational networking, or how the ideologically charged distinctions between emotions and reason, nature and culture, and masculinity and femininity should be explicated in everyday practice. ${ }^{35}$

In the context of my research process, group biographical theory has become organised as a viewpoint that, on the one hand, never ceases to

\footnotetext{
${ }^{33}$ Boydston 2008, 558-559.

${ }^{34}$ Florin 2014, 28-31.

${ }^{35}$ Florin 2014, 31-43.
} 
surprise me with its practicality, yet which, on the other hand, has introduced me to one delicately crafted theoretical framework after another. These acquaintances have been important tools in defining both my research questions and the approach that would be productive as well as apply only to the target individuals and their culture. One of the basic insights was that group biography can be useful in placing men - even educated and established men - inside the cultural processes that Jeanne Boydston described as relational dynamics in her article. The approach allowed me to treat the 'exceptional' characters also as unexceptional factors in a pervasive historical framework that generated possibilities and restrictions for everyone, whether they were 'prominent' or not. In turn, this kind of setup has enabled me to proceed with more critical questions considering the construction of concepts and categories such as masculinity, rationalism and secularism that were and still are significant units in a public discussion that defines what is included in the concept of 'modern Western culture' and what is left out.

\section{Bibliography}

Aalto, Ilana: Isyyden aika. Historia, sukupuoli ja valta 1990-luvun isyyskeskustelussa. Nykykulttuuri, University of Jyväskylä, 2012.

Ahlbäck, Anders: Soldiering and the Making of Finnish Manhood. Conscription and Masculinity in Interwar Finland. Åbo Akademi, Åbo 2010.

Asprem, Egil: The Problem of Disenchantment. Scientific Naturalism and Esoteric Discourse 1900-1939. Brill, Leiden and Boston 2014.

Boydston, Jeanne: Gender as a Question of Historical Analysis. Gender \& History. 3 (2008), $558-583$.

Caine, Barbara: Biography and History. Palgrave Macmillan, Hampshire and New York 2010.

Connell, Raewyn: Masculinities. Second Edition. Polity Press, Cambridge 2005.

Djurdjevic, Goran: India and the Occult. The influence of South Asian Spirituality on Modern Western Occultism. Palgrave Macmillan, Hampshire and New York NY 2014.

Englund, Boel and Kåreland, Lena: Rätten till ordet. En kollektivbiografi över skrivande Stockholmskvinnor. Carlssons, Stockholm 2008.

Florin, Christina: Biografia rajoja rikkomassa. Kolme esimerkkiä ruotsalaisesta elämäkertatutkimuksesta. Historiallinen elämä. Biografia ja historiantutkimus. Eds. Heini Hakosalo, Seija Jalagin, Marianne Junila and Heidi Kurvinen. SKS, Helsinki 2014, 27-44.

Grever, Maria: Fear of Plurality: Historical Culture and Historiographical Canonization in Western Europe. Gendering Historiography. Beyond National Canons. Eds. Angelica Epple and Angelica Schaser. Campus Verlag, Frankfurt and New York 2009, 45-64. 
Group biography as an approach to study manhood and religion

Hakosalo, Heini: Tasohyppelyä. Varhaiset suomalaiset naislääkärit ja historiallisen biografian monimuotoisuus. Historiallinen elämä. Biografia ja historiantutkimus. Eds. Heini Hakosalo, Seija Jalagin, Marianne Junila and Heidi Kurvinen. SKS, Helsinki 2014, 45-61.

Hanegraaff, Wouter J.: Esotericism and the Academy. Rejected Knowledge in the Western Culture. Cambridge University Press, Cambridge 2012.

Hanegraaff, Wouter J. and Pijnenburg, Joyce (eds.): Hermes in the Academy. Ten Years'Study of Western Esotericism at the University of Amsterdam. Amsterdam University Press, Amsterdam 2009.

Harmainen, Antti: Kuinka lemmen tulta hallitaan? J. H. Erkko, sukupuoli ja uskonto 1800luvun lopulla. Sukupuolentutkimus. Genusforskning. 1 (2014a), 20-31.

Harmainen, Antti: "Kaikki voin kestää, voin elää, jos tiedän että hänet kerran vielä tapaan" Spiritualismi ja teosofia surutyön välineinä 1880-luvun lopulla. Historiallinen aikakauskirja. 4 (2014b), 381-392.

Hilda \& Elias. Hilda Aspin ja Elias Erkon kirjeenvaihtoa vuosilta 1884-88. Ed. Marja Niiniluoto. Helsingin Sanomat, Helsinki 1984.

Juva, Mikko: Valtiokirkosta kansankirkoksi. Suomen kirkon vastaus kahdeksankymmentäluvun haasteeseen. WSOY, Helsinki 1960.

Kares, O.: Luther. Henkilökuva ja kehitysaika. WSOY, Helsinki 1945.

Keats-Rohan, Katherine S. B.: Biography, Identity and Names: Understanding the Pursuit of the Individual in Prosopography. Prosopography. Approaches and Applications. A Handbook. Ed. Katherine S. B. Keats-Rohan. Oxford University Press, Oxford 2007, 139-181.

Kinnunen, Tiina: Alexandra Gripenberg's Feminist Christianity. Finnish Women Making Religion. Between Ancestors and Angels. Eds. Terhi Utriainen and Päivi Salmisvuori. Palgrave Macmillan, Hampshire and New York 2014, 61-79.

Leskelä-Kärki, Maarit: Suhteellista elämää. Relationaalisuus ja biografinen vuorovaikutus. Historiallinen elämä. Biografia ja historiantutkimus. Eds. Heini Hakosalo, Seija Jalagin, Marianne Junila and Heidi Kurvinen. SKS, Helsinki 2014, 314-331.

Liikanen, Ilkka: Fennomania ja kansa. Joukkojärjestäytymisen läpimurto ja Suomalaisen puolueen synty. SKS, Helsinki 1995.

Maijala, Minna: Herkkä hellä hehkuvainen Minna Canth. Otava, Helsinki 2014.

Markkola, Pirjo: Seksi, miehet ja moraali. Miesten seksuaalisuus moraalikysymyksenä 1800- ja 1900-lukujen taitteessa. Taivaallista seksiä. Kristinusko ja seksuaalisuus. Eds. Minna Ahola, Marjo-Riitta Antikainen and Päivi Salmesvuori. Tammi, Helsinki 2006, 223-237.

Minna Canthin kirjeet. Ed. Helle Kannila. SKS, Helsinki 1973.

Mosse, George: Nationalism and Sexuality. Middle-Class Morality and Sexual Norms in Modern Europe. The University of Wisconsin Press, Madison WI and London 1985.

Nieminen, Armas: Taistelu sukupuolimoraalista. Avioliitto- ja sukupuolikysymyksiä suomalaisen hengenelämän ja yhteiskunnan murroksessa sääty-yhteiskunnan ajoilta 1910-luvulle. WSOY, Helsinki 1951.

Owen, Alexandra: The Place of Enchantment. British Occultism and the Culture of the Modern. The University of Chicago Press, Chicago 2004.

Possing, Birgitte: Elämä pelissä. Biografian historia ja vastuu. Historiallinen Elämä. Biografia ja historiantutkimus. Eds. Heini Hakosalo, Seija Jalagin, Marianne Junila and Heidi Kurvinen. SKS, Helsinki 2014, 62-78.

Roberts, B.: Biographical Research. Open University Press, London and Buckingham PA 2002.

Stuckrad, Kocku von: Locations of Knowledge in Medieval and Early Modern Europe. Brill, Leiden and Boston 2010.

Taylor, Charles: The Secular Age. The Belknap Press of Harvard University Press, Cambridge, Massachusetts and London 2007. 


\section{Antti Harmainen}

Treitel, Corinna: Science for the Soul. Occultism and the Genesis of the German Modern. The Johns Hopkins University Press, Baltimore and London 2004.

Utriainen, Terhi and Salmesvuori, Päivi: Critical and Creative Turns. Finnish Women Making Religion. Between Ancestors and Angels. Eds. Terhi Utriainen and Päivi Salmesvuori. Palgrave Macmillan, Hampshire and New York 2014, 1-20. 


\title{
Love and emotions in the diplomatic world: The relationship between Bodil Begtrup's public and private lives, 1937-1956
}

\author{
Kristine Kjærsgaard
}

The Danish women's activist and diplomat Bodil Begtrup (1903-1987) is a well-known figure in the study of women's rights in the early days of the United Nations. She chaired the UN Commission on the Status of Women (CSW); she also participated in meetings of the UN Commission on Human Rights, chaired by Eleanor Roosevelt, called to discuss draft texts of the Universal Declaration on Human Rights, which was adopted in December 1948. ${ }^{1}$ In 1949, she became Denmark's first female ambassador when she was politically appointed as envoy, and from 1955 as ambassador, to Iceland, a post she held until 1956. ${ }^{2}$ From 1956-1959, she was Head of Division in the Danish Ministry of Foreign Affairs and permanent representative to the Council of Europe. She was Denmark's ambassador to Switzerland from 1959-1968 and to Portugal in 1968-73, after which she formally retired. ${ }^{3}$

\footnotetext{
${ }^{1}$ Morsink 1991, 229-256.

${ }^{2}$ The second female Danish ambassador was Nonny Wright; she was a career diplomat and appointed ambassador to Ghana in 1967. Lind Olsen, electronic source.

${ }^{3}$ Lind Olsen on Bodil Begtrup, electronic source.
} 
Accounts of her role at the UN, along with her official curriculum vitae, leave the impression of a life story full of success. However, if her public life is juxtaposed with her private life, and also with her own perception of her public life in the world of diplomacy, a different picture emerges. Begtrup experienced several personal challenges. Firstly, she was divorced from her first husband and lost her ten-year-old daughter, who had been born with a heart disease and died from an infection. Secondly, she fell in love with the Danish career diplomat Laurits Bolt Bolt-Jørgensen (1882-1967). Bolt-Jørgensen was twenty-one years older than Begtrup, employed in the Danish Foreign Service from 1921-1949 and already married. It took eleven years and a difficult divorce case before Bolt-Jørgensen and Begtrup could eventually marry in $1948 .{ }^{4}$

Thirdly, Begtrup's appointment as envoy to Iceland was a political decision. She believed that her work with various national and international organisations had qualified her for the position; and yet her appointment was looked upon with profound scepticism within the Ministry, where the staff never really considered her an equal. ${ }^{5}$

The contrast between Begtrup's officially successful public life and the challenges she faced both in her private life and public life raise the question of the degree and ways in which her public and private lives were interconnected. Recent biographical scholarship has argued for the inclusion of the private life of the protagonist. ${ }^{6}$ Danish historian Birgitte Possing and Swedish historian Yvonne Hirdman are examples of Nordic biographers arguing for the inclusion of the private sphere. In her doctoral thesis on the Danish educational pioneer Natalie Zahle, Possing argues for the importance of tracing the 'mental structure' of the historical protagonist - the personal, private and social aspirations, the human driving forces - as being relevant to particular public conduct (as one explanatory factor among several). ${ }^{7}$ In her biography of Swedish diplomat and politician Alva Myrdal, Hirdman argues that use of the correspondence between Alva Myrdal and her husband, Gunnar

${ }^{4}$ Bolt-Jørgensen 1957. A short account of Bolt-Jørgensen's career is found in Lidegaard 1996, 665-666.

${ }^{5}$ Begtrup 1986, 80-81.

${ }^{6}$ See, for example, Magaray 2008, 1-26; Bosch 2009, 13-37.

${ }^{7}$ Possing 1997, 441; Possing 1992. 
Myrdal, 'does not mean that it [the book, KK] is about nothing but love and "everyday life". Rather, I have used the letters to provide a framework for the matters that preoccupied Alva's passionate mind'. However, whereas Possing and Hirdman argue convincingly for inclusion of the private sphere, they also seem to perceive the private sphere as a framework for the public sphere, focusing less on the dual relationship of the two spheres. I will investigate the private and the public sphere as two potentially interdependent spheres, as a two-way relationship with an inherent scope for reciprocal influence.

The purpose of this chapter is to investigate the interconnection between Begtrup's public and private lives in terms of the way in which her private experiences affected her public life and the way in which her public life, her work experiences, affected her nature as a private individual. Furthermore, the purpose is to track what may be termed Begtrup's 'mental structure', that is her personal spontaneities and motivations, and see how these shaped respectively her private and public life. Inspired by the literature on the intertwining of the public-private lives of partners and spouses, the chapter will also pay attention to the impact of Begtrup's relationship with Bolt-Jørgensen and the impact of his life on her privately and publicly. ${ }^{9}$ Finally, it will reflect upon whether the potential private-public interconnection is gender neutral, and whether the private-public lives of women as well as men may be interconnected. To give an answer to this, the chapter will also include a brief discussion of the degree to which Bolt-Jørgensen's public life was affected by his private life. The chapter forms part of a larger biographical project on Begtrup, analysing her international career trajectory in a transnational and historical-sociological perspective with an emphasis on the networks and personal contacts Begtrup engaged in. My discussion reflects on how the private level is relevant and can be dealt with in biographical studies from a historical-sociological perspective.

The chapter will apply Possing's concept and definition of a "mental structure" with the purpose of identifying the emotional level of

\footnotetext{
${ }^{8}$ Hirdman 2008, 6.

9 The intertwining of public-private lives is recently explored in Arrington 2016.
} 
Begtrup's private sphere, the potential emotional driving forces behind her public as well as private conduct. By emotional driving forces and mental structure, I do not mean to establish a psychological portrait of Begtrup, as I believe this endeavour would be out of the reach of history as an academic discipline. Rather, I intend to draw on sociology, to establish Begtrup's apparent emotional approach to her public and private life and what I, with reference to Possing, call her mental structure. I base the study on Begtrup's correspondence with Bolt-Jørgensen and her diaries. I am conscious 'to step carefully and not to thread on' Begtrup's life ${ }^{10}$ as I try to establish her mental structure and use it to characterise and explain her private and public agency without revealing potentially sensitive details of her personal life. I find it possible to establish an overall picture based on her private sources without presenting such potentially sensitive details.

To make an analytical distinction between the private and the public spheres, and also to allocate specific forms of conduct to each of these spheres, the chapter draws on sociologist Erving Goffman's distinction between our "all-too-human selves" and our "socialised selves", which he also calls the "spontaneous self" and the "socialised self". There is, according to Goffman, a tension between the two selves stemming from a difference between what an individual may spontaneously wish to do and what people may expect her/him to do. Individuals are met with the explicit demand or implicit expectation to live up to social expectations in order to maintain a stable self-image, in other words, people perform for their social audiences. Thus, Goffman maintains, the self is a product of the interaction between actor and audience, and is vulnerable to disruption during the performance. Goffman assumes that when individuals interact they wish to present a particular - idealised - sense of self that will be accepted by others. This sense of self will be performed on a "front stage" while facts and performance suppressed on the "front stage" will appear on a "backstage". ${ }^{11}$

${ }^{10}$ See discussion in Possing on the challenges of stepping into the private life of one's protagonist. Possing 2014, 218-251.

${ }^{11}$ Goffman 1959, 109-140. For an introduction to Goffman see Ritzer 1992, 355-359. 
Goffman's distinctions between the "spontaneous self" and the "socialised self", as well as his notions of a "front stage" and a "backstage", will be used in the analysis of the interrelation between Begtrup's professional and private lives; as analytical tools, the categories will separate the two lives while investigating the ways in which the two spheres were interconnected. In particular, the chapter will look at the degree and ways in which Begtrup performed a socialised self on the front stage, the concerns and spontaneities she left backstage and, not least, the extent to which she might or might not have assigned various thoughts and actions to these separate stages. It should be noted that the 'front and backstages' are used as distinct notions which can be separated analytically while the chapter will remain open as regards the degree to which Begtrup actually kept them separate in practice.

The development of their relationship will be followed chronologically over a twenty-year period, starting with their meeting in Geneva in 1937, which provides a suitable platform for analysing the private-public nature of a relationship during which Begtrup's public life was played out in the League of Nations, the UN and as Danish ambassador to Iceland.

\section{Meeting in Geneva, 1937}

Begtrup and Bolt-Jørgensen met at the League of Nations in Geneva in 1937 and soon developed an intimate relationship. Begtrup left Geneva before Bolt-Jørgensen, and he wrote her letters summarizing their experience. He was pleased that their age difference had not prevented her from becoming intimately involved with him. He had found a photograph of her taken during the League's General Assembly, at a moment when they, he believed, 'were not concentrating and forgot to pay attention to the negotiations'. He was frustrated that she did not write to him when she stopped over in Basel on her way back to Denmark. The fact that he was now writing to her was, he stated, 'against the protocol and an unforgivable weakness'. He would soon return to Copenhagen and bury himself in work and preparation for his new appointment in 
Moscow, but he would find it difficult not to look in the direction of her area of the city, which was not that far from the Ministry of Foreign Affairs. ${ }^{12} \mathrm{He}$ was seemingly focused on the protocol, on the norms with which he was expected to comply, anxious to know if she shared his feelings: feelings which he would try to suppress by submerging himself in work. Due to the fact that he was married, their relationship had to be kept secret - backstage. They, nonetheless, managed to maintain their relationship to the extent possible in a long-distance liaison largely shaped, as we will see below, by Bolt-Jørgensen's private and public lives - his marriage and his status within the Ministry of Foreign Affairs.

\section{Backstage emotions, 1937-1948}

On the emotional level, from 1937 until they could marry in 1948, the relationship between Begtrup and Bolt-Jørgensen was marked by longing and frustration, but also by joy and confidence. Their mutual experience of 'happiness, pain, expectations and happiness again' had saved her 'from a general state of disillusion' and given her 'the faith that this strange phantom we all pursue really does exist'. However, 'having seen just a glimpse of a phoenix rising from the ashes makes any compromise so unbearable and all the practical advice from my surroundings to make a decision so evil'. ${ }^{13}$ She was 'always longing to receive [his] letters which made [her] happy and troubled at one and the same time'. She praised his ability to allow her to be tender and to show him that she cared for him. She did 'not have to be something [she was] not, or be afraid that [he would] despise me'..$^{14}$ In 1942, she celebrated her birthday without him and was 'the loneliest person in the world'. ${ }^{15}$ She wrote how

\footnotetext{
${ }^{12}$ Laurits Bolt Bolt-Jørgensen (hereafter LBB-J) to Bodil Begtrup (hereafter BB), undated; 30 September 1937; 1 October 1937; 2 October 1937, Begtrup private papers (hereafter $\mathrm{BB}$ ), box 1, file 1.a. (All quotes from source material are translated by $\mathrm{KK}$ ).

${ }^{13} \mathrm{BB}$ to LBJ, 1942 (undated), BB, box 2, file 2.a.

${ }^{14} \mathrm{BB}$ to LBJ, 1942 (undated), BB, box 2, file 2.a

${ }^{15}$ BB to LBJ, 14 November, 1942, BB, box 2, file 2.a.
} 
she longed to see him and to touch him. ${ }^{16}$ 'I have to see you, to be with you; there are thousands of things that only my hands can tell you', she wrote one Sunday evening - Sundays were worst, as that is the day couples are usually together. ${ }^{17}$

At the same time, they disagreed on various norms and practices. According to Bolt-Jørgensen, she should be more virtuous and economical. She did not agree with these standards. She was only virtuous because she loved him, and only economical to the extent that her financial situation forced her to be so, she insisted. She also preferred to keep their finances separate; she did not want to mix love and money. ${ }^{18}$ Begtrup's position on separate finances suggests a progressive view of the wife in relation to the husband. It seems, however, that she was driven more by their actual financial circumstances than by principled views on the relationship between husband and wife. She also informed him that she had told his lawyer to make sure it was clearly stated in the divorce contract that should Bolt-Jørgensen re-marry, his new wife (i.e. her) would not have to pay any maintenance to his previous wife. ${ }^{19}$

Her ideas about the ideal everyday life and the relationship between wife and husband were quite traditional. She missed having an 'ordinary relationship' in which she, 'just like other wives', was able to 'send [him] parcels' and 'see [him] a couple of times each week'. ${ }^{20}$ The private level was not merely important to her; it was even - perhaps because it was largely missing in her daily life - a driving force: 'A women needs to have a person to work for, a child or a husband, otherwise everything will dry out. ${ }^{21}$ However, since proof of adultery on his part would, by law, preclude divorce, they were forced to keep their emotions on the backstage.

\footnotetext{
${ }^{16}$ BB to LBJ, undated, December 1942 or January 1943, BB, box 2, file 2.a.

${ }^{17} \mathrm{BB}$ to LBJ, 20 Aug, 1944, BB, box 2, file 2.a.

${ }^{18}$ LBJ to BB, 16 January 1943 , BB, box 1, file 1.a.; LBJ to BB, 26 January 1943 , $\mathrm{BB}$, box 2, file 2.a. (No year is mentioned, but it seems to be a response to his letter dated 16 January 1943 . The letter is placed in continuation of several letters dated in the January, one of them dated 1943.)

${ }^{19}$ BB to LBJ, 6 September 1943, BB, box 2, file 2.a.

${ }^{20} \mathrm{BB}$ to LBJ, undated, presumably September 1943, BB, box 2, file 2.a.

${ }^{21}$ BB to LBJ, 7 December 1943, BB, box 2, file 2.a.
} 
Begtrup was especially concerned about missing the possibility of having a child. The loss of her daughter in 1941 and a profound desire to have another child would seem to have been a major driving force and a key factor in explaining why she was so eager to see a resolution of Bolt-Jørgensen's divorce proceedings. They were both getting older and, in terms of having a baby, their age represented a race against time. In December 1943, she complained that:

[--] we circle around like animals confined in a cage waiting to be slaughtered, and I am not doing the only thing that is worth doing: awaiting the birth of a child. This insane person [Bolt-Jørgensen's wife] is preventing me from having what I really want in life, what makes me joyful each day, each month, and when, in two years' time, we eventually have each other all hope will be gone. We may have a couple of years together abroad, and then we will be hopelessly old when we return. [--] If only I was expecting a child now, during this period when I am alone, there would be a meaning in life. ${ }^{22}$

After spending time with friends who had children, her letters would often include remarks about how sweet they were and how she longed to have a child of her own. She was disconsolate when she visited a friend whose children had been friends with her daughter Anne: 'It is almost unbearable to be with them. They were Anne's friends and it broke my heart to see them. Why did I have to lose her? She truly was the only dream of this poor woman, my lovely little girl. On Tuesday, it is two years since she died. ${ }^{23}$ She may appear to be a career woman on the front stage, but her mental structure contained a profound desire to live an ordinary life too, and one which she interpreted in quite traditional terms.

${ }^{22}$ BB to LBJ, 7 December, presumably 1943, BB, box 2, file 2.a.

${ }^{23}$ BB to LBJ, 11 August 1943, BB, box 2, file 2.a. References to events such as the death of her daughter are helpful in establishing when the undated letters where written. 


\section{Bolt-Jørgensen’s divorce case}

Bolt-Jørgensen filed for divorce, citing an unhappy marriage, and he had to establish evidence that the marital relationship had irretrievably broken down. This was a difficult task because not only had the marriage lasted for many years, but his wife cited his adultery. ${ }^{24}$

Until 1946, his wife refused to agree to a divorce. Stationed in Budapest, Bolt-Jørgensen granted Begtrup the authority to deal with the case and ensure that the divorce lawyer worked efficiently. ${ }^{25}$ Largely because of the necessity to avoid evidence of adultery, Bolt-Jørgensen's relationship with Begtrup had to be kept unofficial - which both found difficult. Furthermore, their liaison met with criticism, and they were called to account in their respective professional settings. 'I cannot do it anymore', she wrote to him in January 1943. Her family, however, was 'cordially interested and was looking forward to meeting him. ${ }^{26}$ The backstage aspect of her intimate relationship was clearly a source of frustration. Her family was an important element in her ability to cope with her frustrations.

Another source of frustration was Bolt-Jørgensen's divorce lawyer; Begtrup considered him slow and weak. She hated, she added in a letter, weak men because of the power they sometimes wielded and the harm they could do with it. ${ }^{27}$ Furthermore, she complained that BoltJørgensen's weakness made her weak too, and she was upset by his weakness and lost respect for him. She could not understand how he could take any advice from 'a weak-looking man'. 'I would never have done so', she wrote. ${ }^{28}$ She blamed Bolt-Jørgensen for not fighting hard enough to speed up the divorce proceedings. ${ }^{29}$

${ }^{24}$ BB to LBJ, January 1943 (undated), BB, box 2, file 2.a.

${ }^{25}$ LBJ to BB, Budapest, 22 April, 1941, BB, box 1, file 1.a.

${ }^{26} \mathrm{BB}$ to LBJ, 26 January (no year is mentioned, but the letter is placed in continuation of several letters dated in the January, one of them dated 1943), $\mathrm{BB}$, box 2, file 2.a.

${ }^{27}$ BB to LBJ, 26 January 1943 , BB, box 2, file 2.a.

${ }^{28}$ BB to LBJ, 26 January 1943 , BB, box 2, file 2.a.

${ }^{29} \mathrm{BB}$ to LBJ, 26 January 1943 (no year is mentioned, but the letter is placed in continuation of several letters dated in the January, one of them dated 1943), BB, box 2, file 2.a. 
Eventually, in 1946, Bolt-Jørgensen's wife agreed to a divorce. The divorce settlement was a clear disadvantage economically to Begtrup and Bolt-Jørgensen, as Begtrup admitted, but she had agreed to it on behalf of Bolt-Jørgensen in order to prevent the case dragging on any further. ${ }^{30}$ Eagerness and attempts at efficiency was part of Begtrup's 'mental structure', here pertaining to a situation relevant to her private life, but as we will see, this 'mental structure' was also her approach to issues in her public career.

An agreement of terms was followed by eighteen months of separation before the actual divorce came into effect, after which Begtrup and Bolt-Jørgensen were free to marry. A number of judicial matters also had to be settled before they could eventually marry in May 1948, including permission from the Ministry of Justice in order to avoid official objections. ${ }^{31}$

\section{Divorce and public career - Bolt-Jørgensen}

Bolt-Jørgensen's divorce case was deeply affected by his official position and by diverging views in the Danish Foreign Service over policy during the wartime German occupation of Denmark, 1940-1945. From April 1940, the Danish ambassador to the United States, Henrik Kauffmann, had tried to rally opposition within the Ministry of Foreign Affairs to the government policy of co-operation with the occupying power. On 10 April 1940, he sent a circular telegram to his colleagues in the free world declaring that he could only be committed to working for a 'free and independent Denmark', and he encouraged his colleagues to follow his stance. While initially only a few diplomats voiced their agreement with Kauffmann's line, Denmark's signing of the Anti-Comintern Pact in November 1941 led to broader support. The Ministry of Foreign Affairs responded by demanding that Danish ambassadors worldwide affirm their loyalty to the Ministry and the official Danish policy. Several of the diplomats who broke with Copenhagen were dismissed with-

${ }^{30} \mathrm{BB}$ to LBJ, 10 September, probably 1944, BB, box 2, file 2.a.

${ }^{31}$ LBJ to BB, 17 November, no year, but seemingly 1947, BB, box 2, file 1.d. 
out pensions. Bolt-Jørgensen remained loyal to the Ministry of Foreign Affairs. Following Nazi Germany's attack on the Soviet Union in June 1941, the Danish Ministry of Foreign Affairs broke off diplomatic relations with the Soviet Union and called its ambassador back to Copenhagen. Bolt-Jørgensen had initially sought to reach an agreement with the Soviet Union and to remain in his post without breaking with the Danish government by declaring his representation of a free and independent Denmark. Above all, however, the internment of Soviet diplomats in Copenhagen made it untenable for Bolt-Jørgensen to stay in the Soviet Union. Kauffmann reproached Bolt-Jørgensen for not taking the opportunity to declare his independence from Copenhagen and remain in Moscow to demonstrate that Denmark had no part in the German attack on the Soviet Union. Due to his loyalty to the Ministry, and his departure from Moscow in 1941, Bolt-Jørgensen was among those Danish diplomats criticised by dissenting voices in the Ministry and by the press, both during and after the war, for leaning towards Nazi Germany and for the fact that, until 1944, Denmark had no diplomatic representation in the Soviet Union. ${ }^{32}$

After the August revolt in 1943, Bolt-Jørgensen emphasised his loyalty to the departmental policy. Begtrup was highly critical, 'paralyzed', writing that Bolt-Jørgensen had missed a chance to be silent and just take cognizance of the matter. She had to defend his declaration of confidence in the Head of the Ministry, Svenningsen, everywhere she went. The balance of power in the Ministry of Foreign Affairs seemed ambiguous, and there was a serious risk that Bolt-Jørgensen would be among the discredited staff on the 'losing side.'.33

His damaged status at the Ministry had several repercussions on his divorce case. Firstly, Bolt-Jørgensen risked being without financial resources; this contributed to his wife's disinclination to a divorce. As she had told an employee in the Ministry, she would agree to a divorce if she was awarded substantial maintenance. However, for some years

32 Lidegaard 1997, 56; Lidegaard 2004, 461, 611-612; Fischer and Svenningsen 1970, ch. 4.

${ }^{33}$ BB to LBJ, 9 September 1943, BB, box 2, file 2.a.; BB to LBJ, undated, but September 1943 to judge from location in the file and content of the letter, same file. 
it was not certain that Bolt-Jørgensen was in a position to meet her financial demands. ${ }^{34}$ Secondly, Begtrup was troubled by his situation and its impact on their relationship. In April 1945, she told him, apparently in a state of frustration, that she did not want to see him until the war was over and his situation at the Ministry of Foreign Affairs had been resolved. He responded with understanding, since he did not know if he risked being dismissed from the Ministry and, thus, being put into a financially insecure situation. He thought of resigning and, with his background in the commercial sector, seeking another job to supplement his pension. ${ }^{35}$ However, even though his situation remained unclear, Begtrup soon contacted him again and they reconciled. ${ }^{36}$

Thirdly, a group of diplomats and politicians and their wives, and the wives of some very prominent politicians - including the wife of former Foreign Minister P. Munch and of Prime and Foreign Minister Erik Scavenius - criticised Bolt-Jørgensen for committing adultery. They claimed to have written proof that Bolt-Jørgensen had promised never to leave his wife, and also proof that he had left Begtrup's house at 8 o'clock one morning. We know the latter to be untrue, Begtrup emphasised to Bolt-Jørgensen, and went on to tell him that he had to give former Foreign Minister P. Munch an explanation - 'for your sake and for mine' ${ }^{37}$

The relationship between Begtrup and Bolt-Jørgensen was forced to the front stage by the very fact that the divorce case took place and was deemed unacceptable in many quarters. People in Foreign Ministry circles helped put Bolt-Jørgensen's divorce case and his relationship with Bodil Begtrup onto the front stage. The diplomats, politicians and their wives formed a group of social agents who were a factor in shaping the boundaries of Begtrup's and Bolt-Jørgensen's relationship and, hence, in dissolving the distinction between the private and the public spheres.

${ }^{34}$ BB to LBJ, 6 September 1943, BB, box 2, file 2.a.; BB to LBJ, Monday, 20, letter no. 6, undated, but probably September 1943.

${ }^{35} \mathrm{LBJ}$ to BB, 13 April 1945, BB, box 1, file 1.b.

${ }^{36}$ LBJ to BB, 17 September 1945, BB, box 1, file 1.b.

${ }^{37} \mathrm{BB}$ to LBJ, undated, but September 1943 to judge from location in the file and content of the letter, BB, box 2, file 2.a.; Monday, 20, letter no. 6, undated, but probably September 1943, same file. 
Fourthly, the divorce negotiations scheduled for September 1943 were postponed when Bolt-Jørgensen had to stay in Budapest because of the changed situation in Denmark caused by the August 1943 revolt, which made taking leave impossible. ${ }^{38}$ It would seem that Bolt-Jørgensen's standpoint on Danish government policy during the occupation rendered him a discredited figure in the opinion of key diplomats, and his adultery reinforced this negative perception; this all hindered settlement of his divorce proceedings and thus complicated his relationship with Begtrup.

Begtrup in the UN: activism and Bolt-Jørgensen as her advisor

Begtrup was a member of the Danish delegation to the UN in the role of DKN representative. The Scandinavian countries had an established procedure; their Women's Councils each sent representatives to their national League of Nations delegation, and then to the UN. Begtrup's approach to the work of the UN was quite similar to the characteristics of the 'mental structure' manifested in her private life. She was energetically engaged in the delegation work, concentrated on 'doing a good job', was very eager to arrange meetings and to network, and was extremely focused on gaining results. Members of the Danish delegation told her that she was the most successful of them all when it came to making contacts and getting relevant background information. Furthermore, she took advantage of her membership in the delegation to address various influential people and clarify Bolt-Jørgensen's standpoint during the wartime German occupation of Denmark, and, thus, his future prospects in the Ministry of Foreign Affairs. ${ }^{39}$

Bolt-Jørgensen undertook the role of Begtrup's advisor in her UN work. In November 1946, she presented the Third Committee of the General Assembly with the Danish delegation's proposal that UN

${ }^{38}$ BB to LBJ, 11 August 1943; 6 September 1943, BB, box 2, file 2.a.

${ }^{39}$ BB to LBJ, 20 January 1946, Archive of Danish Ministry of Foreign Affairs (hereafter ADMFA), 3G Bodil Begtrup's file 1945-1953, box 1, file, undated (grey-blue file). 
member nations should be obligated to grant women the same political rights as men - the resolution was adopted unanimously. According to Bolt-Jørgensen, it had been daring of her to present the resolution before the CSW had been given the chance to meet and review it: 'You might have discussed it with me first. I am quite knowledgeable in such matters. Things went well this time, so congratulations. ${ }^{240} \mathrm{He}$ also advised her on how to respond to journalists - to be short and precise. ${ }^{41}$ Begtrup's private life and her public life were clearly interconnected, with her husband functioning as her advisor on UN issues.

\section{Begtrup in Iceland: disagreement on norms with Danish Ministry of Foreign Affairs and with her husband}

Begtrup's route into the formal diplomatic world is the chief indicator of a conspicuous interconnection between her private and her public life. She was appointed Danish envoy to Reykjavik (1949-1956, from 1955 as ambassador). ${ }^{42}$ Bolt-Jørgensen had originally been offered the post. However, as he had been due to retire in three years' time, he had not wanted to restrict his wife's career prospects by taking her to Reykjavik, he claimed, and had suggested that Begtrup should be appointed instead. The Foreign Minister and the Prime Minister supported the idea, and the Minister of Foreign Affairs informed the Foreign Policy Committee of the Danish parliament that 'even if it is not the custom' Begtrup had been offered the post of envoy to Iceland. ${ }^{43}$

When stationed in Iceland, Bolt-Jørgensen continued to undertake the role of Begtrup's diplomatic advisor. Begtrup worked on several fronts to improve dealings between Iceland and Denmark - similar to the "mental structure" exhibited at the private level, she was focused and eager, often impatiently so, to create results, make a difference, in

${ }^{40}$ LBJ to BB, Monday 18 November 1946, BB, box 2, file 1.d.

${ }^{41}$ LBJ to BB, 26 November 1946, 12 January 1948, BB, box 2, file 1.d.

${ }^{42}$ Begtrup 1986, 104-105.

${ }^{43}$ Ibid., 80-81; Minutes of the meetings held by the Foreign Policy Committee, 17 November 1948, ADMFA, 3 E 92. 
her own words to 'do good' - namely in the manner that she considered appropriate.

One of the major controversies was Iceland's request that the Icelandic manuscripts collected by Árni Magnússon (1663-1730), and left to the University of Copenhagen, should be returned to Iceland. ${ }^{44}$ Begtrup approached the issue, according to the Social Democratic party leader Hans Hedtoft, 'with an almost Old Norse fanaticism and doggedness', and the president of the Manuscript Commission warned her against appearing to be the Icelandic envoy to Denmark rather than the Danish envoy to Iceland. ${ }^{45}$ Bolt-Jørgensen reminded her that her task was not to work in the interests of Iceland. He was certain that, in this respect, she would have 'an inner struggle. However, you have to remember that you are first and foremost the Danish envoy to Iceland, and in that capacity you are expected to foster goodwill, but never by surrendering what you are meant to maintain or protect. ${ }^{46}$

In January 1956, Begtrup's reaction when told that she was to be called home to Copenhagen again testifies to a mental structure of eagerness and focus on what she saw as 'doing good'. With reference to her popularity in Iceland, she thought that she had contributed positively to an improvement in relations between Denmark and Iceland. ${ }^{47}$ She had emotional reservations about returning to work in Copenhagen; she disliked the highly competitive culture in the Ministry of Foreign Affairs, where she was sure she would be one of the 'hounded' - a position that required 'steady nerves'. ${ }^{48}$

Begtrup was not enthusiastic about the Ministry policy of rotating posts. Bolt-Jørgensen explained to her that she 'should not think in

${ }^{44}$ Davíðsdóttir 1999, 81, 87; Hálfdanarson 2008, 81, 87; Begtrup, Kvinde i et verdenssamfund, 120-123.

45 Begtrup to Hedtoft, 22 August 1951; Hedtoft to Begtrup, 29 August 1951; Begtrup to Hedtoft, 6 January 1952, Hans Hedtoft's private papers (HH), box 25; Diary, 24 November 1958, 7 January 1959, BB, box 28; S. Davíðsdóttir 1999, 85.

${ }^{46}$ LBJ to BB, 29 November 1949 (presumably), BB, box 2, file 1.c.

${ }^{47}$ Translation of articles in Icelandic newspapers, May 1956, ADMFA, 19461972; 3 G Bodil Begtrup file, box 1, ADMFA.

${ }^{48}$ Dairy 1955-1956, 8, 10, 25 January 1956, 14 February 1956, undated, but between 9 and 14 February 1956, undated March 1956, BB, box 28. 
Kristine Kjærsgaard

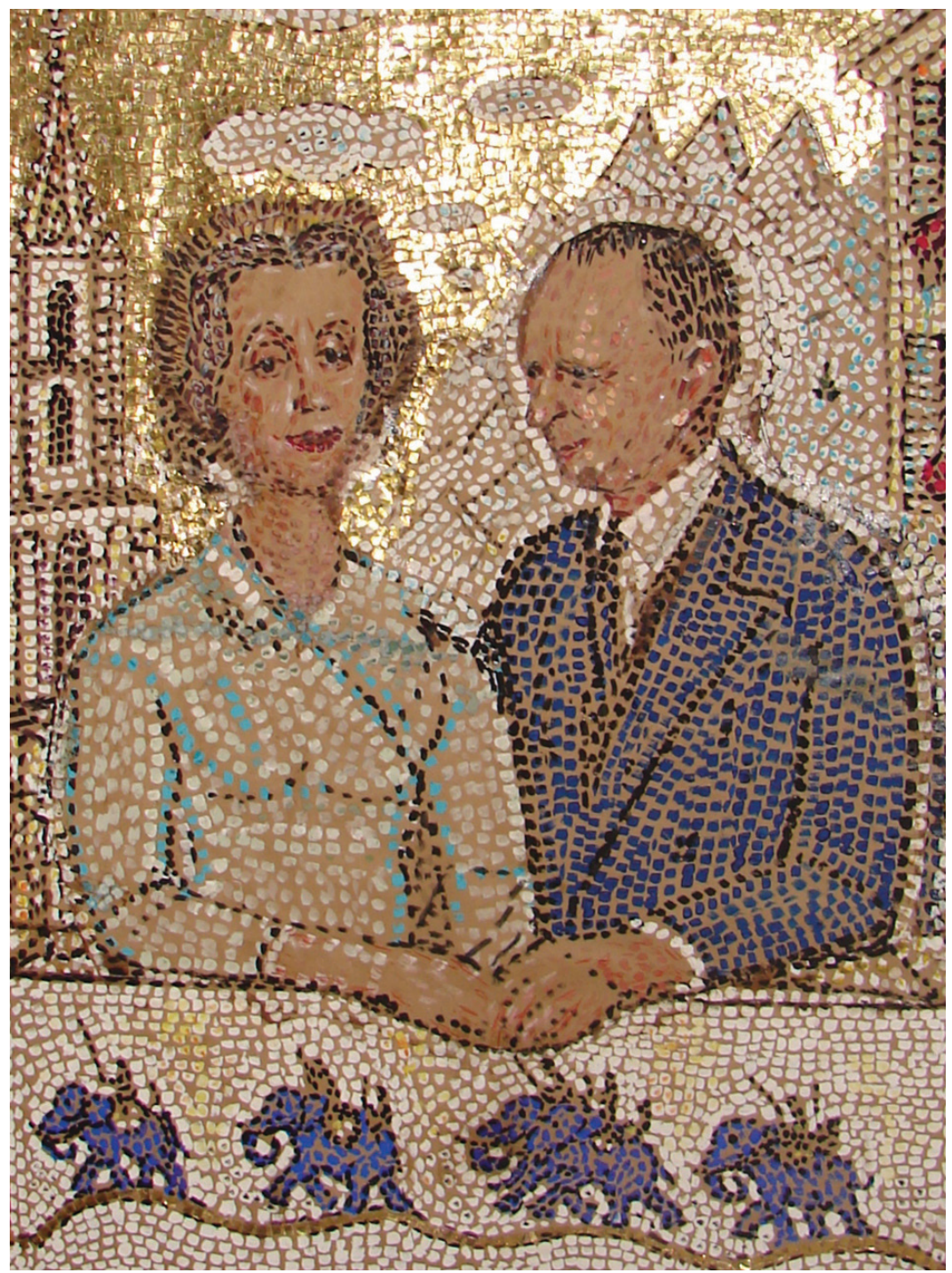

Portrait by Karl Larsen of Bodil Begtrup and her husband Lauritz Bolt-Jørgensen.

(Year unknown, privately owned.) 
terms of having been a success' in Iceland. An envoy was not supposed to be popular, but respected, and certainly not so popular that it might cause problems for the successor. According to Begtrup, this procedure was 'nonsense' and, as she confessed to her diary, 'they knew that Denmark could have no better representative in Iceland. Copenhagen just followed conventional practice. ${ }^{49}$

In contrast to Begtrup, Bolt-Jørgensen was a career diplomat embodying traditional Foreign Ministry norms. Begtrup was sceptical of foreign ministries as such. When the Swedish economist, Gunnar Myrdal, was appointed financial counsellor for the Swedish diplomatic mission to the United States, Begtrup remarked that 'for once a ministry of foreign affairs, and a Swedish one at that, has had an original idea...$^{50}$ Begtrup may be characterised as a fiery soul who approached her public duties with a mental structure similar to the one with which she approached her private dealings. Her spontaneous nature shaped her private as well as her public life. She refused to be 'socialised' into the conventional practices of the Ministry of Foreign Affairs, and she insisted on her right to pursue her own basic approach to diplomatic matters rather than to refer her spontaneities to a backstage.

\section{Conclusion}

So is it all just about love and emotions, as Hirdman also asked? The answer is - as was Hirdman's conclusion - a resounding no. Begtrup's and Bolt-Jørgensen's private and public lives were relentlessly intertwined. In fact, the case study demonstrates that it is very difficult to distinguish, other than analytically, between the two protagonists' public and private lives. Their careers, i.e. their public lives, were deeply affected by their private lives. And their private lives were correspondingly deeply affected by their careers. Bolt-Jørgensen's private life con-

\footnotetext{
${ }^{49}$ Diary 1955-1956, undated, but between 9 and 14 February 1956, undated March 1956, BB, box 28.

${ }^{50}$ BB to LBJ, 29 July $1943, \mathrm{BB}$, box 2, file 2.a.
} 
tained, arguably, two levels: firstly, one concerning his first wife and their divorce, and, secondly, his relationship with Bodil Begtrup. Both levels were affected by his public life, i.e. his status in the Danish Foreign Service. This is an important point, as it shows that conflict between the public and the private spheres is applicable to men as well as to women. The case study thus suggests that the private dimension should be included in biographic studies of men and women alike.

Begtrup's "mental structure", i.e. her personal spontaneities and motivations, consisted of a spontaneous eagerness, a good degree of impatience, and an aspiration to 'do good', notably according to the way in which she was convinced herself of how to do so. This mental structure shaped both her private life with Bolt-Jørgensen and her public life in Danish diplomacy. Whereas Goffman's notions of "front stage" and "backstage" may serve as analytical tools to separate private and public selves, in the case of Begtrup and Bolt-Jørgensen they could not be separated in real life, but remained relentlessly interconnected. Begtrup maintained a front stage as a career women while, at the same time, keeping the sorrow of the loss of her daughter and her relationship for several years with Bolt-Jørgensen on the backstage. However, even if Begtrup appeared as a career woman, she did, in fact, little to present an idealised self on the front stage. She did not push her personal spontaneities and perceptions of how to approach private or public matter to the backstage. Rather, both her approach to her personal life with Bolt-Jørgensen, including his divorce case, and her public life in the diplomatic world was soon shaped by her personal perception of how to approach matters. Even if her approach would conflict with both her husband and the Danish Foreign Service, she maintained it on the front stage. 


\section{Bibliography}

\section{Archive material}

Archive of the Danish Ministry of Foreign Affairs (ADMFA), 1946-1972

3G, Bodil Begtrup's file 1945-1953, box 1 .

3 E 92, Minutes of meetings held by the Foreign Policy Committee. Hans Hedtoft's private papers $(\mathrm{HH})$, box 25.

Bodil Begtrup's private papers (BB), box 1, 2, 28

\section{Literature}

Arrington, Lauren: Revolutionary Lives: Constance and Casimir Markievicz. University Press, Princeton 2016.

Begtrup, Bodil: Kvinde i et verdenssamfund. Centrum, Viby J 1986.

Bolt-Jørgensen, Laurits Bolt: Med sabel og kaarde. Thaning \& Appels Forlag, Copenhagen 1957.

Bosch, Mineke: Gender and the Personal in Political Biography. Observations from a Dutch Perspective. Journal of Women's History. 21:4 (2009), 13-37.

Davíðsdóttir, S.: Håndskriftsagaens Saga-i politisk belysning. Translated by Kim Lembek. Odense Universitetsforlag, Odense 1999.

Fischer, Paul and Svenningsen, Nils: Den danske udenrigstjeneste 1770-1970. Vol. 2: 19191970. J.H. Schultz, Copenhagen 1970.

Hálfdanarson, G.: 'Værsågod Flatøbogen.' Håndskriftsagen og afslutningen på Islands kamp for selvstændighed. Rejse gennem Islands historie - den danske forbindelse. Ed. Soren Mentz, Gads Forlag, Copenhagen 2008.

Hirdman, Yvonne: Alva Myrdal. The Passionate Mind. Indiana University Press, Bloomington \& Indianapolis 2008 .

Jasper, James M.: The Art of Moral Protest. Culture, Biography, and Creativity in Social Movements. The University of Chicago Press, Chicago and London 1997.

Lidegaard, Bo: I Kongens Navn. Henrik Kauffmann i dansk diplomati 1919-58. Samleren, Copenhagen 1996.

Lidegaard, Bo: Danmarks uafhængige udenrigstjeneste 1940-1945. Historisk Tidsskrift, 1997.

Lidegaard, Bo: Dansk udenrigspolitiks historie, vol. 4: Overleveren, 1914-1945. Gyldendals Leksikon, Copenhagen 2004.

Lind Olsen, Pernille: Bodil Begtrup (1903-1987). Dansk kvindehistorie: Dansk kvindebiografisk lexikon. http://www.kvinfo.dk/side/597/bio/32/origin/170/query/bodil\%20begtrup/ (accessed 15 November, 2013)

Lind Olsen, Pernille: Nonny Wright (1909-2003). Dansk kvindehistorie: Dansk kvindebiografisk lexikon. http://www.kvinfo.dk/side/597/bio/1693/origin/170/query/nonny\%20wright/ (accessed 15 November, 2013)

Magaray, Susan: Three Questions for Biographers: Public or Private? Individual or Society? Truth or Beauty? Journal of Historical Biography. 4 (2008), 1-26.

Morsink, Johannes: Women's Rights in the Universal Declaration. Human Rights Quarterly. 13:2 (1991), 229-256.

Possing, Birgitte: Viljens styrke. Natalie Zable - En biografi om dannelse, køn og magtfuldkommenhed. Vols. 1-2. Gyldendal, Copenhagen 1992.

Possing, Birgitte: Biografien - en frisk eller en skæv bølge. Historisk Tidsskrift 2 (1997).

Ritzer, G. (ed.): Sociological Theory. 3rd edition. McGraw-Hill International editions, New York 1992. 


\section{CONTEXT}




\title{
'Fighting Sisters': \\ A comparative biography of Ellen Key (1849-1926) and Alexandra Gripenberg (1857-1913) in the contested field of European feminisms
}

\author{
Tiina Kinnunen
}

Feminist controversies as an object of historical analysis

In 1903, a play entitled Yksitoista naista [Portraits, or Eleven Women] was presented in the foyer of the Finnish National Theatre in Helsin$\mathrm{ki}^{1}{ }^{1}$ The play was written by Alexandra Gripenberg, a leading figure in Suomen naisyhdistys [Finnish Women's Association] and also an internationally well-known feminist activist. It was humoristic in style, but the content of the play was serious. It reflected on the debate on women's rights, an issue that involved men and women in different countries and across borders. The driving force behind the play was Gripenberg's need to respond to the Swedish author Ellen Key, a vocal critic of the middle class women's movement since the late 1880s. This issue erupted

1 Originally, the text was written in Swedish. An excerpt in Finnish has been preserved in Tuulio 1959. This chapter is a revised version of Kinnunen $2014 a$. 
in full force in Sweden and Finland in 1896 when Key's Missbrukad kvinnokraft [Misuse of Women's Power] was published.

In the play, the setting is a picture gallery at midnight where a number of famous women step out of their portraits to discuss their views on women's rights and the future of femininity. In her play, Gripenberg has the characters, who were real historical persons that had never met each other in real life and were already dead in 1903, voice a number of views from the Nordic debates of the 1890s and early 1900s that provided a critique of Key and were in line with Gripenberg's own views. To give weight to her own views as well as those of her contemporaries, Gripenberg used the authority of history and notable feminist pioneers and other women worthies. For example, Fredrika Runeberg, the wife of a famous Finnish poet and an author herself, would never have been able to disavow Key's views, as they had not yet been presented during her lifetime (she died in 1879). Although Elizabeth Cady Stanton, a pioneer of the American women's movement, was a contemporary of Key, English translations of Key's books were not available in her lifetime. Gripenberg makes Stanton ask Fredrika Bremer, a trailblazer of women's rights in Sweden in the mid-nineteenth century, what she thought of Key. Bremer responds: 'Ellen Key can thank the women's movement for her freedom, education, income and status in society, and yet she swears eternal hatred for feminist women - women like you, Mrs. Stanton, and me.'2

The play left no doubt as to which view its author espoused. Gripenberg used Stanton's and Bremer's names to make sharp criticisms of Key. For her, Key's views posed a serious threat to women's emancipation and human progress in general. Relations between Key and the Finnish Women's Association had still been warm in the late 1880s when Key visited Finland for the first time and spoke as an invited guest of the Association. But by 1899, the time of her second visit, the situation had changed. At the time, Gripenberg wrote indignantly to her Swedish confidante Ellen Fries about how Key was using every opportunity to polemicise against the women's movement. ${ }^{3} \mathrm{Key}$, in turn, criticised

\footnotetext{
${ }^{2}$ See e.g. Kinnunen 2009, 181-183.

${ }^{3}$ Gripenberg to Fries 10 December 1899, A.G. Coll. SKS.
} 


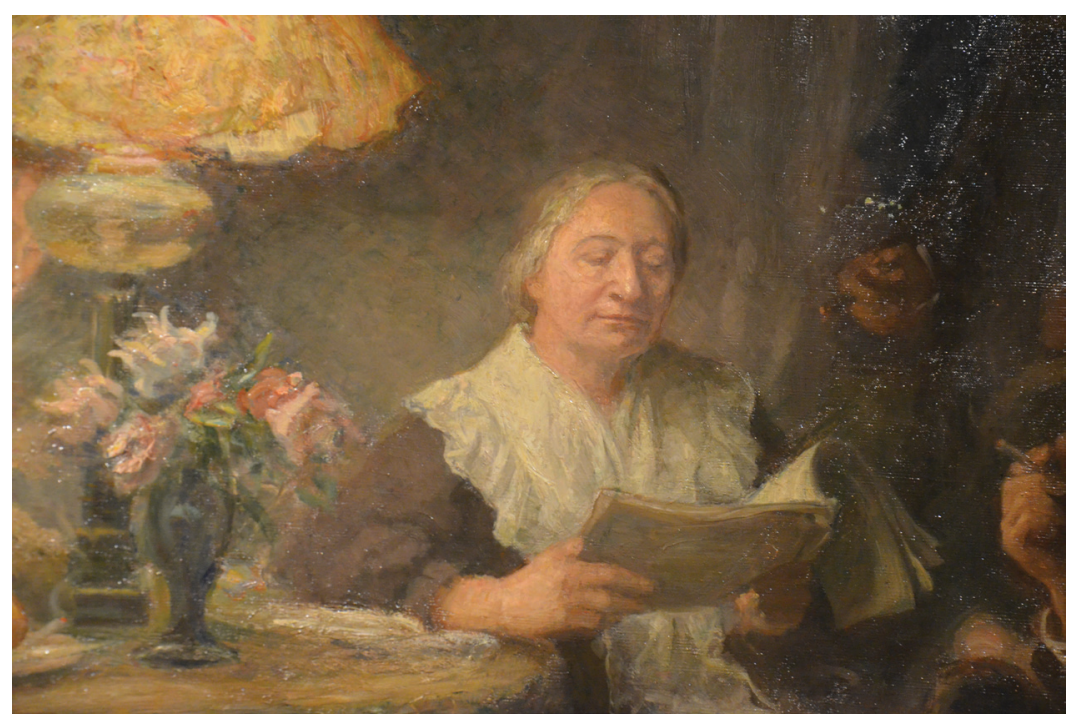

Portrait of Ellen Key by Hanna Pauli (1864-1940). (Wikimedia Commons)

Gripenberg by name in her book Barnets arrhundrade (Century of the Child), published in 1900, as a result of Gripenberg's opposition to special protection for women workers. Key herself strongly supported every effort to protect all women, whom she viewed as potential mothers. Due to the numerous translations of the book, this criticism not only came to the attention of the Nordic audience but also spread more broadly. Gripenberg's determination to prevent Key's ideas from spreading across borders resulted in attempts to build a united front against Key in the Nordic countries, and more broadly in Europe. For example, in 1900, she urged her Swedish confidante Anna Hierta-Retzius to participate in a Paris women's rights conference because she wanted to keep a tight grip on who was representing Scandinavia at feminist gatherings. ${ }^{4}$

For the most part, few historical studies on feminism have paid attention to the dispute between Key and Gripenberg. I argue, however, that an analysis of the controversy from various perspectives can illuminate

${ }^{4}$ Gripenberg to Hierta-Retzius 12 May 1900, A.G. Coll. Helsinki City Archives. 
the complex history of feminism as a social phenomenon and ideology. For instance, the play 'Portraits, or Eleven Women' provides material for an analysis of how history writing was instrumentalised in feminist circles. ${ }^{5}$ Another alternative is provided by a biographical approach. This chapter examines the use of biography in studying the history of feminism, and, in particular, how the controversy between Key and Gripenberg can be approached in this respect. When a portrayal includes two protagonists, the biographer is forced to find an alternative to the traditional biography with its focus on one person. Accordingly, this chapter discusses the usefulness of comparative biography as a special case of biography, a concept which is adopted from John Milton Cooper Jr. ${ }^{6}$

The controversy between Key and Gripenberg alludes to the fact that nineteenth- and early twentieth-century feminism was a contested field, one in which class, religion, and ethnicity, among others, intersected and influenced individual conceptions of emancipation. In that sense, it is useful to speak of feminisms, in the plural. In addition, the controversy opens up a perspective to map the transnational agency of individual feminists as well as transfers and circulations of feminist ideas across national borders. ${ }^{7}$

The early stages of research on the history of feminism discerned differences between feminists who highlighted gender difference in contrast to feminists who underlined gender similarity, but soon it was realised that it was not possible to draw a clear dividing line between different groups of feminists based on this argument. A large number of socalled first wave feminists called for equality between women and men specifically on the basis of gender difference. In this discourse, womanhood was often defined in terms of motherhood and motherliness. ${ }^{8}$ Gripenberg and Key both belonged to this group. Notwithstanding this similarity, they became adversaries. Both saw herself as an advocate of women's genuine interests and the other as an enemy. ${ }^{9}$ Gripenberg con-

${ }^{5}$ See e.g. Kinnunen 2009, 183-201.

${ }^{6}$ Milton Cooper Jr. 2004. See also Ribberink 2012.

${ }^{7}$ Concerning the transnational aspect of feminism, see e.g. Janz and Schönpflug (eds.) 2014.

${ }^{8}$ On the complexity of feminist politics and ideology, see e.g. Offen 2000.

${ }^{9}$ In a letter to Fries (23 August 1897, A.G. Coll., SKS) Gripenberg defined Key as an enemy and thus to be counteracted. 


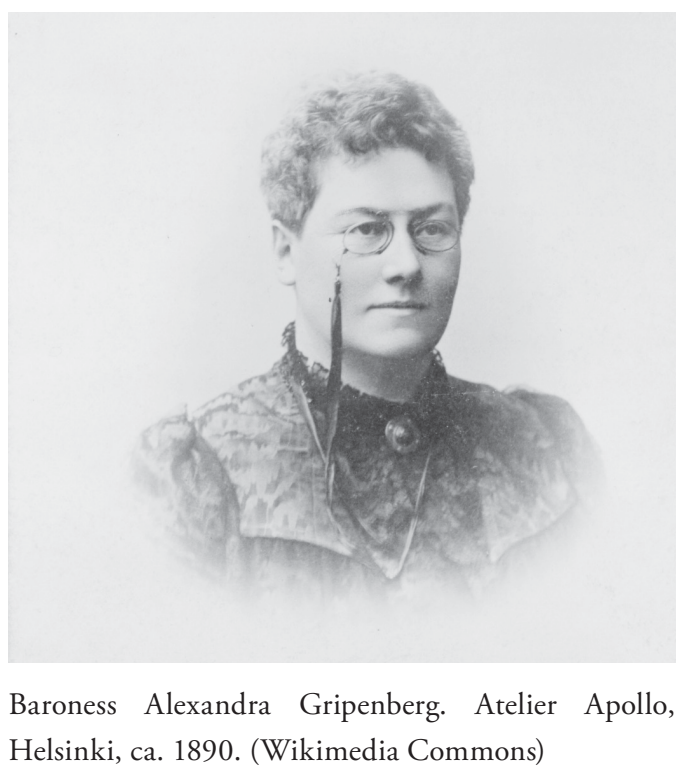

demned Key because, according to her, Key represented backwardness and thus a threat to human progress. Key, in turn, thought that the women's movement in Scandinavia and the English-speaking world (Gripenberg included) was unwittingly narrowing gender difference, which she considered detrimental to the progress of human culture.

With these apparently contradictory arguments and politics, the case of Key and Gripenberg exemplifies the complex history of feminisms and is, thus, highly interesting. As a result, I have launched a research project that approaches this bipartite history through a comparative biographical method. The working title of the project is 'Fighting Sisters'. The dispute, in itself, has not garnered much attention in the biographies of these two women and nor has a comparative approach in general been applied in these books. Although in her biography of Gripenberg, Aleksandra Gripenberg. Kirjailija, taistelija, ihminen (1959), Tyyni Tuulio does examine Gripenberg's antagonistic attitude towards Key after the appearance of Missbrukad kvinnokraft, Tuulio does not examine the controversy from Key's perspective. Tuulio's biography is, at present, the only description of Gripenberg's entire life. Ellen Key, in 
turn, has been the object of several biographical works. The most recent and comprehensive is Ellen Key. En europeisk intellektuell (2012), written by Ronny Ambjörsson. Gripenberg does not figure in this biography at all.

Nevertheless, my approach is similar to Ambjörnsson's in that we both see our protagonists as prism $\mathrm{s}^{10}$ through which different issues can be thematised; in my case, they concern intellectual and ideological differences within feminism as well as the networks that were formed as a result of the contoversy. Prism biography is defined by Birgitte Possing as a form that uses individuals as windows to depict and analyse the historical processes with which they are involved. ${ }^{11}$ Initially, my starting point in the present project was firmly within the history of politics and ideas. However, after familiarising myself with the writings of Key and Gripenberg and their mutual relationship, my original interest has broadened. I have also begun to appreciate my protagonists as female personalities with unique life experiences - not only as embodiments of certain ideas and ideals - and particularly as emancipated, intellectual women at a time when new spaces were opening up for women in the public sphere.

The working title of my research, 'Fighting Sisters', reflects the twofold scope of my interests. My study will include an analysis of the dispute about the right path of feminism, and, in doing so, focus on Key and Gripenberg as adversaries. In addition, I will examine how their respective life experiences and circumstances influenced their particular feminisms, how they lived as modern women in different contexts, and how they, as international feminist intellectuals, promoted - fought for - their vision of a new womanhood in a new society. In this respect, there are interesting similarities between the two protagonists, and the notion of fighting will convey a different meaning.

In such a study, one of the key problems to be solved is that of structure. One must decide how to create a structure that, firstly, allows a narrative of two lives in parallel as well as, secondly, an analysis of the intellectual antagonism between the protagonists while also intertwi-

\footnotetext{
${ }^{10}$ Ambjörnsson 2012, 12.

11 Possing 2015, 104-105.
} 
ning the two aspects in an elegant way. In the following, I will test whether the notion of 'fighting sisters' could serve such a purpose. The section entitled 'The parallel lives of Ellen Key and Alexandra Gripenberg' follows their lives in parallel and highlights their respective work for a re-thinking of gender relations and other related reforms, whereas the section entitled 'The controversy over true feminism' introduces another angle and goes into the dispute between them. Both angles employ comparison as a method. As an introduction, I will discuss briefly the relation between microhistory and biography and the concept of comparative biography as far as they are relevant to the methodological basis of my work.

A comparative microhistorical method and biographical writing

My project is inspired, for instance, by the Finnish historian Irma Sulkunen's ideas about combining the biographical approach and microhistory. As mentioned in the introduction of the present volume, Sulkunen has published a trilogy in which she depicts and analyses the lives of three Finnish women with the aim of deciphering the societal and political processes that formed Finnish society from the end of the eighteenth to the middle of the twentieth century. Reflecting on her book on Miina Sillanpää (1989), in which the focus is on the public life of Sillanpää, who was appointed Minister of Social Affairs in 1926, Sulkunen explains as follows: 'Through the activities of Miina Sillanpää, perhaps Finland's most notable female politician, the book traces, in particular, the changes that took place in the social system of gender when paid employment became more common and class society more firmly established.' ${ }^{12}$ In her biography on Mandi Granfelt (1995), an activist for Finnish cultural nationalism and a schoolteacher as well, the focus is on the experiences, thoughts, and emotional life of the protagonist, and in so doing, the book examines the internal paradoxes of the

${ }^{12}$ Sulkunen 2009a, 66. 
'natural' calling of women as mothers, educators and homemakers that was introduced as modern femininity.

According to my interpretation, Sulkunen's approach to biography is methodologically quite similar to that of historians like Alice Kessler-Harris. In 2009, Kessler-Harris explained her view of biographical research as follows: 'For years I resisted the notion that an individual life could speak to the larger historical processes I was interested in exploring... I think now that I was wrong - perhaps not about the way many biographies are written, but about what a historian can bring to biography. ${ }^{13}$ As indicated in the introduction of this volume, the discussion in recent years about how to differentiate between microhistory and biographical writing has yielded no definitive conclusion apart from the view that there is a reciprocity between the two. This is also reflected in my own study: my stated goal is to shed light on the complexity of European feminisms as an intellectual, political and social phenomenon in the pre-First World War years by putting focus on two individuals and their lives. This approach, as discussed thoroughly in this volume by Erla Hulda Halldórsdóttir, is based on an understanding of microhistory as a way to see individual cases as windows into wider issues or, in other words, as crystallizations of larger phenomena.

When studying two people who lived contemporaneously, comparison becomes a natural angle as it can help divulge differences and similarities between the persons as well as their relationship. John Milton Cooper Jr. has defined comparative biography as an approach in which the subjects under study are followed throughout their lives and their stories are told keeping in mind the other. According to him, only relatively few individuals in history can be entirely compared. Cooper makes it a condition of comparison that the individuals are at least partly contemporary and have dealt with each other. ${ }^{14}$ Gripenberg and Key fulfill this requirement. Although they did not necessarily meet, they did take a position on each other's ideas in their public speeches, published writings and private correspondence, and networks were built or at least strengthened based on their mutual antagonism, particularly across the

\footnotetext{
${ }^{13}$ Kessler-Harris 2009, 625-630.

${ }^{14}$ Cooper Jr. 2004, 95, 99.
} 
Gulf of Bothnia. In their published writings, the women sometimes directly named each other and sometimes referred to each other without providing a name. Gripenberg especially practiced the latter, which I interpret as an effort to invalidate her opponent.

Correspondence reveals that Gripenberg expended much energy combatting Key as a person, or as a personification of a set of ideas, whereas for Key, Gripenberg's ideas were part of a larger discourse and Gripenberg, as a person, was of lesser significance. However, one must be careful of overinterpreting the source material. In the case of Gripenberg and Key, one has to be wary of the impression that Gripenberg's life would have been drained by the dispute with Key. The dispute also reveals certain, less flattering features of Gripenberg's personality, but an analysis of her other relationships no doubt reveals other aspects of her character.

\section{The parallel lives of Ellen Key and Alexandra Gripenberg - pioneering women as fighters for feminist ideas}

A comparative perspective guides one to examine differences and similarities between the subjects in one's research. As the focus of my study is on the feminist lives and thoughts of my protagonists, as well as on a comparison of them in relation to each other and within relevant contexts, it is not necessary for me to bring all the details of their life stages or aspects of their activities to the attention of the reader. Only the details relevant to my analysis need be included. This, of course, applies to every research work, biographical or not, but in a study of two persons, one has to be very careful of burdening the reader with unnecessary details. It is critical to consider what is a sufficient enough description to ensure that the reader remains involved in the plot. On the other hand, I, as the interpreter of Key's and Gripenberg's feminist lives, feel that I must 'know' both of them as accurately as possible, as it is difficult to know in advance what is relevant. This 'knowing' requires extensive work on source materials in at least two countries and in several languages. 
Below, I will present a brief summary of how Key and Gripenberg both engaged in societal matters. ${ }^{15}$ Although their feminisms were on a collision course, many similarities in their lives are apparent, and these mainly can be explained by their backgrounds. Both came from a socially privileged class: Alexandra's father belonged to the nobility as did Ellen's mother. Due to their gender and in spite of their upper-class status, neither received a formal education but took their studies mostly in private. As was customary at the time, the education of upper-class girls focused on the study of languages. As a result, both women had very good language skills, which furthered their international activities. Both insisted on the right to proper education and professional training for girls and women, and for coeducation as well. Key went even further and called for common schools for children from different social backgrounds.

Key and Gripenberg were pioneers in many respects. As writers and lecturers, they were prominent public figures, and Gripenberg was also a party politician. Key, too, was familiar with party politics, as she worked as her father's assistant, who was an MP. In line with her father, Key took a liberal position on issues, and from the 1880s onwards, she became known as a champion for freedom of speech. Deprived of her father at an early age, Gripenberg's political awakening occured under the guidance of her sisters and within the framework of the nationalist Fennoman movement and related feminism. Inspired by the nationalist ideology, the Swedish-speaking Gripenberg also tried to embrace the Finnish language. In particular, she channeled her public activities into the Finnish Women's Association, which was part of the Fennoman movement. For Gripenberg, national and women's emancipation were intertwined issues. National context as a factor is significant here: national emancipation, including language issues, was not a main political concern in Sweden, so it was not among Key's primary interests. However, during Norway's struggle for independence, she actively supported the Norwegians, which provoked a great deal of irritation among Swedish middle-class, nationally-oriented feminists. Concerning the situation in Finland, Key expressed her support for the Finns' struggles

15 This summary is mainly based on Tuulio (1959) and Ambjörnsson (2012). 
against Russification, which was launched in the 1890s and posed a threat to the autonomous status of Finland in the Russian Empire. In regard to the language issue in Finland, she sympathised with bilingualism. Her networks with Finns were mainly restricted to the Swedishspeaking intellectuals and related circles.

After the Finnish parliamentary reform of 1906, which included the introduction of the universal vote and eligibility, Gripenberg was among the first nineteen female members elected to Parliament. In her few years in Parliament, she served as a representative of the conservative Finnish Party. In line with other women MPs, she worked, in particular, to improve women's and children's living conditions. However, this field was also a contested one and Gripenberg was very critical of socialism, the socialist women's agenda included, as she associated the socialists' efforts with anti-Christianity, sexual radicalism and restrictions on women's work. Key, in turn, took a more favourable view of socialism, but did not join the ranks of the party or any other party. She saw education as a key in lifting up the lower class, and accordingly, lectured on a large variety of topics for working class audiences. Key was also not active in the organised women's movement, although in her writings she argued for women's rights and supported intellectual, legal and political equality. In regard to women's work, she strongly favored special protection for women workers. As pointed out, Gripenberg disagreed with her on this matter, as she saw gender-specific legislation as a restriction of women's rights. Key's sympathy for the labor movement increased her support among socialist women in Sweden as well as in Finland. Gripenberg regarded urban working class women as a political lost cause and, instead, looked to the large agrarian population as the ideal group to be educated to citizenship.

To support herself, Key had to work as a teacher from the beginning of the 1880s to the end of the 1890s. After this, she could devote herself to writing and lecturing. Her books and articles argued for a thorough reform of gender and class relations, and she also became known as an advocate of religious radicalism. Due to her practical experience as a teacher, but also as a result of her strong belief in human progress through education, she dedicated much of her work to pedagogical issues. Barnets Arhundrade, in which she outlined a radical reform of 
education and the status of children, became an international bestseller. Gripenberg, being economically independent, was able to devote herself to association activities and writing. She edited the feminist journal Koti ja Yhteiskunta [Home and Society], which she described to Maria Cederskiöld, a Swedish journalist and one of her confidantes, as a journal with a strict feminist agenda. Generally, this referred to working in Christian spirit for women's emancipation and opposing Ellen Key's brand of radicalism. According to Gripenberg, Key's ideas relegated women to 'sexhood', whereas the goal of emancipation was 'humanhood'. ${ }^{16}$ Besides her journal, the three-volume work Reformarbetet till förbättrandet av kvinnans ställning [Reformwork for the improvement of women's status, 1896-1903], which outlined the history of women and women's rights in the Western world, can be considered her main contribution to feminist publishing.

Both Key and Gripenberg were internationally active; as such, they can be seen to exemplify the overlap between the national and transnational in pre-First World War feminisms and other reform movements. Gripenberg, 'one of the great international women-networkers of the period' $^{17}$, participated mainly within the framework of the International Council of Women (ICW) $)^{18}$, while Key had a reputation throughout Europe as a public lecturer and writer ${ }^{19}$. Her books were also read overseas, for example, in the United States and Japan. The public activities of both women was made possible not only by their privileged backgrounds, which provided them with cultural and economic resources, but also by the fact that as unmarried women they were not bound by obligations associated with family life.

Gripenberg died of illness already in 1913. As she died before the outbreak of the First World War, we can only speculate as to how she would have reacted to the war. In Sweden, Key adopted an active stance in favour of pacifism. ${ }^{20}$ The outbreak of violence was a hard blow to her

\footnotetext{
${ }^{16}$ Gripenberg to Cederskiöld 20 September 1900, A.G. Coll.: Helsinki City Archives; Gripenberg 1905.

${ }^{17}$ Zimmermann 2009, 161.

${ }^{18}$ See e.g. Kinnunen 2016.

${ }^{19}$ On Key's popularity in the German Empire, see e.g. Kinnunen 2000.

${ }^{20}$ See e.g. Ellen Key, War, Peace and Future (1916).
} 
optimistic belief in the linear progress of history and she never wholly recovered from the tragedy. However, in her wartime writings, she developed solutions to put an end to the fighting as well as visions of postwar society. When she died in 1926, she was widely commemorated as a visionary reformist.

The controversy over true feminism - Alexandra Gripenberg and Ellen Key on a collision course

In addition to the parallel lives of Key and Gripenberg presented in the previous section, the narrative of 'fighting sisters' also alludes to the aspect of controversy. Key and Gripenberg fought for their respective visions, but they also fought each other, or to be more precise, each other's ideas. In order to analyse this aspect of their story, I will employ an episodic structure based on moments or events in which the lives of my protagonists intersected - if not on a face-to-face level, at least on a discoursive level when their ideas collided. These moments or events open 'windows' into the discord and, thus, provide material for a comparative analysis. Some of the moments or events can also be used to shed light on the networks that the controversy created or strengthened. Making these moments and events understandable to the reader requires detailed contextualisation. This represents a hermeneutic circle of interpretation: a single event requires a broad understanding of Key's and Gripenberg's lives and thinking, and in turn, individual events refine and deepen this understanding.

In the following, I will clarify how this might work in practice. I have chosen Helsinki in November and December of 1899 as the 'scene' to be closely contextualised and interpreted. The discussion of 1899 is preceded by an analysis of the years 1888 and 1896 from the viewpoint of the controversy. In 1888, when both Finnish and Swedish middle-class feminists still considered her to be 'one of us', Key visited Helsinki as a guest of the Finnish Women's Association. As Gripenberg was travelling in England and the United States, the paths of my protagonists did not cross here. The lecture Key gave on married women's property rights was 
published somewhat later and Gripenberg herself recommended it as useful reading in women's reading circles. The visit to England and the US was of great importance to Gripenberg's development as a feminist. In particular, it strengthened her conviction that feminism and Christianity could (and should) be combined. According to my interpretation, this emphasis on Christianity as a cornerstone of women's emancipation is vital to understanding why Gripenberg so vigorously fought the ideas that Key began to spread in $1896 .{ }^{21}$

In 1896, Gripenberg travelled to Stockholm and was invited to give a speech at a gathering against Key. ${ }^{22}$ Key's alienation from organised middle-class feminism was a gradual process, but, ultimately, she fell into disgrace as a result of her provocative ideas in Missbrukad kvinnokraft (1896). The debate on the book was closely followed by Gripenberg and her circles in Finland. In 1898, Key's book Tankebilder [Images of thoughts] was published and provided a new provocation with her bold vision of new womanhood and criticism of conventional sexual morals. This book, too, was known and debated in Finland at the time that Key came to Helsinki in 1899.

In 1899, Ellen Key travelled to Helsinki to celebrate her $50^{\text {th }}$ birthday with Finnish friends. Key, who was known as a skilled speaker, also gave a series of lectures, mostly on historical themes. The lectures more than pleased the large audiences, and the press would refer to a 'presentation of wit the equal of which has not been seen in our city in years. ${ }^{23}$ However, not everyone agreed with the praise offered by the press; Alexandra Gripenberg complained to Ellen Fries, one of her Swedish confidantes, that Key's lectures included a message against the women's movement. Fries was sympathetic: 'I would think that you had enough with Bobrikof in Finland without getting Ellen Key into the bargain. ${ }^{24}$ Gripenberg's reference to Key's lectures indicates that she was present at the lectures. However, she did not attend the dinner arranged in Key's

${ }^{21}$ See e.g. Kinnunen 2014b, 61-79.

${ }^{22}$ Gripenberg 15.8.1896.

23 'Neiti Ellen Keyn kolmas luento', in Päivälehti 3.12.1899.

${ }^{24}$ Gripenberg to Fries 10 December 1899; Fries to Gripenberg in Dec. 1899 (cite), A.G. Coll., SKS. Bobrikof, a representative of the Russian Tsar, was here used as a metaphor for the Russification policies. 
honor, which she expected would result in public disapproval: 'Some of us who refuse to join will be called narrow-minded and spiteful.' ${ }^{25}$

Gripenberg's analysis of the lectures was accurate; they continued Key's criticism of the organised women's movement that she had first summarised in Missbrukad kvinnokraft. For example, her view that 'the civilised women of the sixteenth and seventeenth centuries had such a great influence on their contemporaries that they did not attempt to imitate men, but further developed their own feminine natures ${ }^{26}$ repeated the theme that she presented in her polemical work. By saying this, Key wanted to encourage nineteenth-century feminists not to undervalue the importance of women's unique contribution to human progress, namely intuition, emotions, and motherliness. This was a strong historico-political argument. In contrast, Gripenberg was of the opinion that, above all, history evidenced the inequality experienced by women; they had never had any genuine influence and it was contrary to the aims of the women's movement to claim otherwise. ${ }^{27}$

Key's ideas were controversial among feminists, but she did not represent reaction in the sense that she would have objected to demands for women's political, legal, economic and social emancipation. However, Key was concerned about the impact of emancipation in terms of what she saw as true femininity, and in her Helsinki lecture, she repeated her warning that the politics of the middle-class women's movement put gender difference in jeopardy. Gripenberg did not accept this argument, and to her, Key was only providing ammunition that opponents could use in preventing women's emancipation. Instead of serving the goal of true equality, she interpreted the message of Key's lecture as a celebration of uneducated women.

In one of her lectures in Helsinki, Key brought up older women's right to love. ${ }^{28}$ This reflects her positive and open attitude towards women's sexuality, which was rather atypical in the era. Her sexual radicalism also included criticism of marriage as an institution, and

${ }^{25}$ Gripenberg to Fries 11 December 1899, A.G. Coll., SKS.

26 'Neiti Ellen Keyn esitelmää...', in Päivälehti 30.11.1899.

27 See e.g. Gripenberg 1905, 5. On feminist uses of history, see e.g. Grever 1997, 364-374.

28 'Ellen Keys andra föredrag', in Hufvudstadsbladet 1.12.1899. 
she argued that marriage should be based solely and entirely on (heterosexual) love. Right of divorce, common-law marriage and the equal status of children born out of wedlock were among the practical issues that she saw as crucial for her vision of reformed marriage and family life. ${ }^{29}$ These ideas were presented in her 1898 book Tankebilder and were further developed in subsequent publications. In public, Gripenberg rejected even the slightest reference to sexual radicalism, and advocated strict moral standards for both genders, but within her private circles she might even joke about Key's ideas. Even as late as 1906, in a letter to her Finnish confidante Ida Yrjö-Koskinen, she considered the possibility of experiencing a 'grand passion' at her advanced age. Her use of the concept, which stems directly from Key's lecture in Helsinki, reveals - in addition to her sense of humor - how present Key and her provocative visions were in the thoughts of her contemporaries. ${ }^{30}$

From Gripenberg's perspective, Key's sexual radicalism should be rejected because it threatened women's true emancipation 'from sexhood to womanhood' and, as such, the progress of the human 'race' as a whole. Key's radical position on sexuality also sparked widespread international condemnation. On the other hand, her ideas resonated among some transnational reformers, feminists included. In Finland, Annie Furuhjelm was one of the few middle-class feminists who wholeheartedly supported Key's ideas. She was an editor of the journal Nutid [Present Time], which, under her editorship, challenged the agenda of Gripenberg and her circle in feminist politics. For Furuhjelm, Key's lectures in Helsinki represented 'an intellectual highlight', as she stated in her journal. Also her correspondence with Key gives evidence of her positive attitude toward a radical re-interpretation of concepts linked to love and sexuality. ${ }^{31}$

In addition to protective legislation, issues of family, love and sexuality were at the core of the controversy between Key and Gripenberg. In this situation, Ellen Fries, to whom Gripenberg unburdened herself in regard to Key's 1899 visit, was one of her most important Swedish

\footnotetext{
${ }^{29}$ See e.g. Lindén 2002.

${ }^{30}$ Gripenberg to Yrjö-Koskinen 16 February 1906, A.G. Coll., SKS.

${ }^{31}$ Furuhjelm 1900; Furuhjelm to Key, L 41:59, Kungliga Bibliotek.
} 
confidantes, along with Anna Hierta-Retzius and Maria Cederskiöld. Fries also provided Gripenberg with some of the counterarguments that she used in the Finnish debate. At the core of their relationship was the shared view that only fidelity to the ideals of Christianity guaranteed 'a happy ending for our dearest cause. ${ }^{32}$ Drawing on the views of Spencer, Spinoza, and Nietzsche, Key developed her own worldview, which she called an 'evolutionist-monistic belief of life'. ${ }^{33}$ According to her, this vitalist belief in life would promote progress and emancipate humanhood. Freedom of love and women's unique capacity to love were a prerequisite and a result of emancipation. A central aspect of her work, this message had a prominent place in her lectures in Helsinki.

Concluding remarks about the usefulness of a comparative approach in relating feminist lives

The aim of my comparative biography of Alexandra Gripenberg and Ellen Key is to contribute to international scholarship of feminism as a transnational intellectual, political and social phenomenon, as well as to add to the discussion on how biographies of feminists and other pioneer women might be written. A narrative of their lives that embraces the notion of parallel lives provides the reader with knowledge and interpretation about how the lives of the protagonists were shaped by the national and transnational contexts in which they actively participated. As these stories are told 'keeping in mind the other', as John Milton Cooper Jr. puts it, particular attention will be paid to those aspects that are comparable.

In my own project, this perspective will prove to be very useful because it, among other things, encourages me to examine sides of my protagonists that would, perhaps, otherwise go undetected in an individual biography. Key opens up a perspective that can revise and

\footnotetext{
${ }^{32}$ Gripenberg 1896. See also Hammar 2000, 49-57. On Gripenberg's feminist networks in Sweden, see Hirvonen 2015.

${ }^{33}$ On Key's religious development, see Ambjörnsson 2012, 463-532.
} 
relativise the rather negative image of Gripenberg that prevails in Finland. Above all, the reasons for this have been her conservative attitude with respect to suffrage reform and patronising attitude towards lower class women. ${ }^{34}$ These features of Gripenberg's life cannot be denied, nor is there reason to, but, nevertheless, they can be historicised through an examination of the educational projects that Key envisioned for the working class. It should not go without noting that Key, whose relationship with the working class has been depicted in a much more positive light, also had quite a patronising attitude toward the lower classes.

Furthermore, parallel and comparative approaches help to overcome the methodological nationalism that has directed much of previous research and to open up transnational perspectives. As a result of the former, Key's life has been written mainly from a Swedish perspective and in the Swedish context, Gripenberg, respectively, from a Finnish one. In this sense, Gripenberg opens up a new perspective to look at Key. Previous research concerning Key's life has done little in the way of examining her feminism in the context of nationalism. This can be explained by the fact that, in general, the Swedish women's movement has only marginally been examined from this perspective, and Key has been viewed mainly in relation to the Swedish context. However, Key herself wrote rather extensively about the topic, especially during World War I but also prior to this period, for instance, during the union conflict between Sweden and Norway. When examined in tandem with Gripenberg, this aspect is easier to recognise. In addition, the union conflict connected Key and Gripenberg in an interesting way. Based on her nationalist attitude and particularly her disapproval of the Russification measures in Finland, one might expect that Gripenberg would have supported the Norwegian campaign against Swedish hegemony. However, this was not the case and it was, in fact, Key who whole-heartedly supported the Norwegians in their struggle for independence, earning her a degree of dispproval from many middle-class Swedish feminists with whom Gripenberg was networking in order to combat Key. ${ }^{35}$

\footnotetext{
${ }^{34}$ See e.g. Sulkunen 2009b, 83-105.

35 Gripenberg to Cederskiöld 20 July 1905, 15 November 1905, A.G. Coll. Helsinki City Archives.
} 
As this chapter shows, my study also explores Key and Gripenberg from the perspective of controversy. A narrative and analysis of their lives as 'fighting sisters', in the sense of fighting each other, will shed light on the nineteenth- and early twentieth-century feminism as a contested field. Although both Key and Gripenberg based their thinking on the concept of gender difference and demanded a gender equality that took difference into account, this was not a sufficient basis for cooperation between the two. Instead of co-operation, they saw each other as enemies. Furthermore, they both used the written and spoken word as well personal contacts and networks to combat the ideas propagated by their counterpart, whom they viewed as harmful for human progress.

My analysis of the reasons for the controversy places this specific Key vs Gripenberg case in the broader context of modernisation and highlights the role of religion. In so doing it creates a dialogue with Antti Harmainen's chapter in this volume. By challenging the traditional religious-based discourses of gender, feminism was integral to the discourses about modernity and change. The heated debates among feminists about love and sexuality were (partly) nurtured by religious controversies. Feminists either rejected traditional religions (mainly Christianity or Judaism), like Key did, or pushed for a renewal of religious tenets as vital for sustainable emancipation, like Gripenberg did. Both standpoints resonated among feminists across Europe and overseas. ${ }^{36}$ Key and Gripenberg provide a Nordic perspective on this discussion. Not only did they adopt ideas from transnational debates and respond to these within their native contexts, but they also actively participated in the debates transnationally, either as a lecturer and writer (like Key), or as an activist (like Gripenberg).

My primary aim is not to draw portraits of Key and Gripenberg as personalities, but, inevitably, my work also provides perspectives on these aspects. Nevertheless, I will only make observations on the traits that were realised in the struggle that developed between them. Their differences of opinion did not have to preclude productive discourse between them. However, this became the case, and Gripenberg actually devoted a fair amount of time to the struggle against Key, which might

${ }^{36}$ See e.g. Morgan 2002; Schwartz 2013. 
paint a portray of her as a rather fanatical person. On the other hand, one could also develop an image of her as someone who, like Key, was willing to courageously fight for her own convictions and, thus, build a new type of womanhood.

The notion 'fighting sisters' allows a multilayered interpretation of feminism that, besides sisterhood, also includes hierarchies, divisions, and - when there was a struggle over correct ideology - efforts to silence contending viewpoints. In doing so, it challenges the idea that biography should avoid dealing with uncomfortable sides of the protagonist(s). Feminist historians have not always felt comfortable with biography, because it was associated with the production of heroic figures ${ }^{37}$. The aim of feminist history - closely linked to social history - was associated with the agency and experiences of ordinary women. Key and Gripenberg were not ordinary women, but in my research, they are not viewed straightforwardly as heroines either. Conversely, I argue that feminist history, like other histories as well, has the function to inspire and empower people, offering the reader something that might be called role models. In my opinion, humanizing historical actors is the best way to achieve this. This is one of the aims of my ongoing research.

\title{
Bibliography
}

\section{Archival and newspaper sources}

\author{
The Literature Archive of the Finnish Literature Society (FLS) \\ Alexandra Gripenberg's Collection (A.G. Coll.) \\ Letters between Gripenberg to Fries. \\ Letters between Gripenberg and Yrjö-Koskinen \\ Helsinki City Archives \\ Gripenberg's Collection in the Archives of the Finnish Women's Association, \\ Gripenbergs letters to Cederskiöld \\ Gripenbergs letters to Hierta-Retzius \\ Kungliga Bibliotek, Stockholm \\ Ellen Key Collection \\ Furuhjelm to Key (L 41:59)
}

${ }^{37}$ See e.g. Bosch 2012, 226-227. 
Gripenberg, Alexandra: 'Sananen naisasiasta ja naisista Ruotsissa', in Koti ja Yhteiskunta 15.8.1896.

Furuhjelm, Annie: 'Ellen Keys föredrag.' Nutid 1/1900.

'Neiti Ellen Keyn kolmas luento.'Päivälehti 3.12.1899.

'Neiti Ellen Keyn esitelmää...' Päivälehti 30.11.1899.

'Ellen Keys andra föredrag.' Hufvudstadsbladet 1.12.1899.

\section{Literature}

Ambjörnsson, Ronny: Ellen Key. En europeisk intellektuell. Albert Bonniers förlag, Stockholm 2012.

Bosch, Mineke: Well-Behaved Women Seldom Make History, But If They Do... - Reflections on Gender and Biography. Life Writing Matters in Europe. Eds. Marijke Huisman et al. Universitätsverlag Winter, Heidelberg 2012, 223-240.

Cooper Jr., John Milton: Conception, Conversation and Comparison: My Experiences as a Biographer. Writing Biography. Historians \& Their Craft. Ed. Lloyd E. Ambrosius. University of Nebraska Press, Lincoln, London 2004.

Gripenberg, Alexandra: Naisasian kehitys eri maissa I. WSOY, Porvoo 1905.

Grever, Maria: The Pantheon of Feminist Culture: Women's Movements and the Organization of Memory. Gender \& History. 9:2 (1997), 364-374.

Hammar, Inger: From Fredrika Bremer to Ellen Key: Calling, Gender and the Emancipation Debate in Sweden, c. 1830-1900. Gender and Vocation. Women, Religion and Social Change in the Nordic Countries, 1830-1940. Ed. Pirjo Markkola. SKS, Helsinki 2000, 49-57.

Hirvonen, Maija: Vapaaherratar Aleksandra Gripenberg. Unelma suuresta sisaruudesta. Naisten aika. Valkoinen varis ja muita oppineita naisia. Eds. Riitta Mäkinen and Marja Engman. Gaudeamus, Helsinki 2015, 87-112.

Kessler-Harris, Alice: Why Biography? The American Historical Review. June 2009, 625-630.

Kinnunen, Tiina: History as Argument - Alexandra Gripenberg, Ellen Key and the Notion of True Feminism. Gendering Historiography. Beyond National Canons. Eds. Angelika Epple and Angelika Schaser. Campus, Frankfurt/Main 2009, 181-207.

Kinnunen, Tiina: The National and International in Making a Feminist: The Case of Alexandra Gripenberg. Women's History Review 4:25 (2016), 652-670.

Kinnunen, Tiina: 'Eine der Unseren' und 'Königin im neuen Reiche der Frau'. Die Rezeption Ellen Keys in der Frauenbewegung des deutschen Kaiserreichs. Yliopistopaino, Tampere 2000.

Kinnunen, Tiina: “Taistelevat sisaret." Kaksoiselämäkerta Ellen Keystä ja Alexandra Gripenbergistä eurooppalaisina feministeinä. Historiallinen elämä. Biografia ja historiantutkimus. Eds. Seija Jalagin, Marianne Junila, Heini Hakosalo and Heidi Kurvinen. SKS, Helsinki 2014a, 205-222.

Kinnunen, Tiina: Alexandra Gripenberg's Feminist Christianity. Finnish Women Making Religion. Between Ancestors and Angels. Eds. Terhi Utriainen and Päivi Salmesvuori. Palgrave Macmillan, New York 2014b, 61-79.

Lindén, Claudia: Om kärlek. Litteratur, sexualitet och politik hos Ellen Key. Symposion, Stockholm 2002.

Morgan Sue (ed.): Women, Religion and Feminism in Britain, 1750-1900. Palgrave Macmillan, Basingstoke 2002.

Offen, Karen: European Feminisms. A Political History. Stanford University Press, Stanford 2000.

Possing, Birgitte: Ind i biografien. Gyldendal, Aarhuus 2015. 
Ribberink, Anneke: Margaret Thatcher and Gro Harlem Brundtland: Two Women Prime Ministers from the Spectre of Comparative Biography. Life Writing Matters in Europe. Eds. Marijke Huisman et. al. Universitätsverlag Winter, Heidelberg 2012, 241-258.

Schwartz, Laura: Infidel Feminism: Secularism, Religion and Women's Emancipation, England 1830-1914. Manchester University Press, Manchester 2013.

Sulkunen, Irma: Biography, Gender and the Deconstruction of a National Canon. Gendering Historiography. Beyond National Canons. Eds. Angelika Epple and Angelika Schaser. Campus, Frankfurt/Main 2009a, 65-77.

Sulkunen, Irma: Suffrage, Nation and Political Mobilization - the Finnish Case in an International Context. Suffrage, Gender and Citizenship: International Perspectives on Parliamentary Reforms. Eds. Irma Sulkunen, Seija-Leena Nevala-Nurmi and Pirjo Markkola. Cambridge Scholars Publishing, Cambridge 2009b, 83-105.

Tuulio, Tyyni: Aleksandra Gripenberg. Kirjailija, taistelija, ihminen. WSOY, Porvoo, Helsinki 1959.

Zimmermann, Susan: The challenge of multinational empire for the international women's movement. Globalizing Feminisms 1789-1945. Ed. Karen Offen. Routledge, New York 2009, 153-169. 


\title{
Telling stories of gendered place and space: The political agency of the Swedish Communist Valborg Svensson (1903-1983)
}

\author{
Irene Andersson
}

A political activist in a gendered context

Valborg Svensson was born in 1903 in the southern part of Sweden and lived to celebrate her 80th birthday. She started to work as a maid at fifteen, and later continued at a textile factory. At a dance arranged by Communist Party members in the local People's House, she got involved in politics, and after some years, decided to move to Stockholm. There, she again took employment in a household and tried to organise other maids in unions. The Swedish Communist Party wanted her to be an agitator and sent her to Communist schooling in the Soviet Union in the early 1930s. In Moscow, Valborg Svensson met the Norwegian Communist Arvid G. Hansen, with whom she then lived in a commonlaw marriage for some years. In Sweden, a couple of years later, she was offered the position of editor for Arbetarkvinnornas tidning [Working women's paper] and was also included in the Party's central committee. Her political agitating placed focus on women, visible in pamphlets for housewives. Valborg Svensson engaged in solidarity work for Spain 
during the Civil War, for children in Leningrad during the Second World War, and subsequently for women and children in Vietnam in the 1960s. In 1942, she was elected to the Stockholm City Council, where she worked with social questions for twenty years. After the war, she joined Svenska Kvinnors Vänsterförbund, SKV, [Swedish women's leftist federation], which was open to Communists from 1946, and was connected to the newly established Women's International Democratic Federation, WIDF. For several years, she was responsible for SKV's periodical, Vi Kvinnor i Demokratiskt Världsförbund/Vi Mänskor [We women in international democratic federation/We people].

In this chapter, Valborg Svensson is situated in a gendered political context with keywords such as agitation for maids and housewives, solidarity with women and children, and engagement in social questions, women organizations and women's papers. The narrative is constructed on sources telling stories of her private life, her work activities as well as her political interests. These sources include surveillance materials collected by the Swedish Secret Police between the 1930s and 1960s and a printed interview from the 1970s conducted by a former leader of the Communist Party for a book project on Swedish Communists. ${ }^{1}$ Furthermore, there is a theatre manuscript Jösses flickor! [Oh, dear girls!], produced in the same decade in connection to the new women's movement, and a radio interview broadcast on International Women's Day in $1983 .^{2}$

Valborg Svensson was not a political activist who left behind many written sources. Her personal archive in the Labour Movement Archives in Stockholm includes no private papers and consists only of one small box containing drafts or copies of some political speeches. ${ }^{3}$ Traces of her political activities can be found only in minutes from organizations and political debates, newspaper articles (mainly in the Communist press), and in some of her own rhetorical political pamphlets. ${ }^{4}$ Due to the lack of personal papers, the sources I have chosen to discuss on her political

${ }^{1}$ Svensson, Personakt 2263, 4 vol, The Secret Police and Hermansson, 1977.

${ }^{2}$ Garpe and Osten, 1977; Radio interview, 1983-03-08.

${ }^{3}$ Svensson. Ref. code 563, vol:1, ARAB, Stockholm.

${ }^{4}$ Arbetarkvinnornas tidning 1930-1947; Svensson 1934a, 1934b, 1940 and 1942; Tomson 1964 and 1966; För Spanien, 2011. 


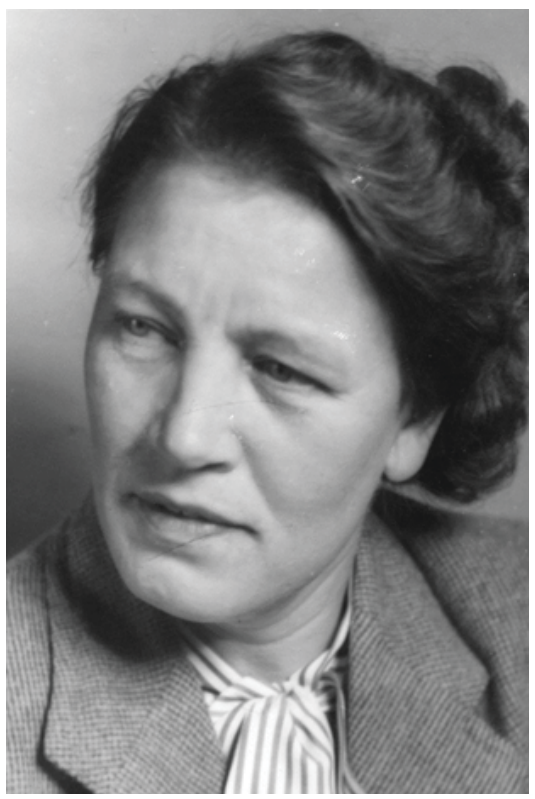

Valborg Svensson. (1903-1983). Photo: Ny Dags arkiv (New Days archive), Labour Movement Archives and Library, Stockholm, Sweden.

activism are more complex than the ordinary material used in biographical work. I will categorise them as 'voices of others', because they are constructed and arranged narratively by others for their own special purposes. This is obvious in the case of the surveillance acts and the theatre manuscript. In the radio interview, the authentic voice of Valborg Svensson is actually heard, and in the printed interview, her answers can be read. Still, since both interviews are structured, edited and mediated by the interviewers, I will also treat them as voices of others.

When I first came across Valborg Svensson's personal files in the Secret Police archive, I wondered how it might be possible to do biographical writing on the basis of surveillance information alone, if other material was limited. I decided to working on a biography of Valborg Svensson in which I use the concepts of gendered place and space and 
political agency as the central methodological tools. For the purposes of this particular chapter, however, I will focus on the sources and discuss which challenges I faced and how I used these tools.

In seeking ways on how to relate the sources to agency in social and political contexts, I have been inspired by different scholars in the field of biographical approaches. In her introduction to the anthology Documents of Life Revisited. Narratives and biographical methodology for a $21^{\text {st }}$ century critical humanism, the sociologist Liz Stanley stresses how social life gives people the capacity to construct the meaning of their own life agency. Following Ken Plummer's classic work, she categorises source material as 'documents of life', and defines it as 'texts which are everyday, representational and significant in organizing and shaping lives. 5 This could be anything, regardless of genre, traces and fragments of daily life such as receipts, tickets, timetables, photos, notes and messages. By reading and putting them together as new stories of social life, researchers in the interpretation process may encounter untested questions with regard to their project. ${ }^{6}$ Furthermore, when Toril Moi analyses how an intellectual woman is created, by focusing on texts written by Simone de Beauvoir, she reads them as networks of texts forming a subject, a discursive network. ${ }^{7}$

Despite Stanley's and Moi's different theoretical contexts and interpretations, I argue that the manners in which they understand their sources are thoughtful as images. In my case, the four sources used in this chapter are, in some ways, intertwined as elements of networks and, in particular, the scattered pieces of information on activities in the surveillance files are documents of life that were systematically collected by others. In Telling stories. The use of personal narratives in the social sciences and history, Mary Jo Maynes, Jennifer L. Pierce, and Barbara Laslett discuss not only how statements of agency form a subject but also how the narratives situate and bind the individual to the surrounding social life. ${ }^{8}$

\footnotetext{
5 Stanley 2013, 5.

${ }^{6}$ Stanley 2013, 5-6.

${ }^{7}$ Moi 1996.

${ }^{8}$ Maynes, Pierce and Laslett 2008.
} 
Entrepreneurs, comrades and communist women's activism

Although Valborg Svensson had a central position in the Swedish Communist Party for three decades, she cannot be characterised as an intellectual of the movement; instead, she was a person who actively subordinated herself in reference to the movement. She was offered a political place and she used the space by working hard to fulfill the duties demanded. Her hard work was recognised in an obituary notice in 1983 and in an anniversary text celebrating the women's organisation SKV. ${ }^{9}$ Historians Ronny Ambjörnsson and Sverker Sörlin categorise people who did not form political ideas or hold central positions in movements as 'entrepreneurs of ideas' in daily life: 'The entrepreneurship took form in their actions and projects rather than in original, canonised written documents. ${ }^{10}$

Political work took place in different places and spaces, constructing the agency of Valborg Svensson. I am, in a broad sense, inspired by feminist geography and the idea that aspects of social and political life take place in gendered locations, both in material and non-material places and spaces. I will discuss how concepts of gendered place and space are helpful both when mapping out patterns of political agency for biographical writing and as analytical tools for examining possibilities and boundaries concerning political work in a movement with a gendered agenda. In her book Finding the Movement: Sexuality, Contested Space, and Feminist Activism, Anne Enke has shown how place matters when it comes to political movements. The book is about women's activism in an urban landscape, how alternative places and spaces were created, and how access to public space changed during the 1960s and 1970s in some American cities. She analyses where movements took place and how spaces were utilised. ${ }^{11}$

Since 1994, the journal Gender, Place \& Culture: A Journal of Feminist Geography has been one platform for exploring how gender coded lives are lived, experienced, and practiced in and across different rooms,

\footnotetext{
${ }^{9}$ Palmaer 1983, 3 and 1989, 2-3.

${ }^{10}$ Ambjörnsson \& Sörlin 1995, 7-8, translation by IA.

${ }^{11}$ Enke 2007.
} 
places, and spaces - which are all gendered. When Louise C. Johnson, fifteen years later, reflects upon the agenda and the content of the journal, she analyses a tension between discursive and political activism and finds women's inequality and difference being taken for granted. ${ }^{12}$ Yet, as suggested in the same journal, political mobilization has often been interpreted as grounded in gender difference. However, this interpretation is countered with a critique for overlooking politics of sameness and an argument that women do not always mobilise due to gender issues and gender differences. ${ }^{13}$ In the Communist movement, the concept of comradeship was frequently used. An analysis of images of this comradeship might contribute to a deeper understanding of how political gender was constructed, whether it was based on a gender difference or on a concept of sameness. Andrés Brink Pinto has studied norms in connection to comradeship, primarily in fictional texts in magazines published by the Swedish Communist movement during the interwar years. He finds female comradeship more complex than male comradeship, with reference both to the fighting comrade and to family and heterosexuality. ${ }^{14}$

My motivation for choosing the political agency of Valborg Svensson for biographical study is because it allows for an examination of women's activism in a changing political (Communist) and gendered context before and after the Second World War. The historian Kjell Östberg gives several examples of women's political space in Sweden after the introduction of women's vote in parliamentary elections, in 1921. In the same year, the Communist International rejected independent women's associations. Instead, women's secretariats under the direction of the Communist Parties were allowed. While female industrial workers constituted the core of recruitment during the 1920s in Sweden, housewives and the women's communist clubs were central during the 1930s. After the war, SKV, connected to the International Federation, became responsible for organizing Communist women's politi-

\footnotetext{
12 Johnson 2008.

13 Staeheli 2004.

${ }^{14}$ Brink Pinto, 2008.
} 
cal work. ${ }^{15}$ Communist women's work was transnational by nature. In a Nordic context, Pirkko Kotila has worked biographically on Hertta Kuusinen in Finland, focusing on her international contacts and her role in welfare politics during the 1950s and 1960s. ${ }^{16}$ In Scotland, in turn, Neil Rafeek has conducted oral history research and has been listening to voices of Communist women in Glasgow. In his work he finds that women have been marginalised in the writing of the movement's history. ${ }^{17}$ What stories do the voices of others in this chapter tell about the political actor Valborg Svensson in a national and ever-present international political context?

\section{Dangerous threats in the Secret Police files}

The surveillance material was constructed by others for a special purpose. It was mainly to control Valborg Svensson's Communist activities and, in particular, her international contacts in the middle of the 1930s and in the beginning of the 1940s, at a time when the Swedish Communist Party was at risk of being prohibited due to its international contacts with Komintern and Moscow, and for fear of subversive activities that were hostile to the state. ${ }^{18}$ The data were collected by frequently used methods in surveillance work, such as scrutinising available information, cross-reading other surveillance files, and using reliable informants and witnesses. In this material, voices of others, unknown to me, judge Valborg Svensson, on the one hand, as a dangerous activist with international contacts and, on the other hand, as an insignificant member of

15 Östberg 1997, 62-64. See also Gogman 2010; Gunnarsson 1977.

${ }^{16}$ Kotila 2006. Also, cultural historian Hanne Koivisto has extensively examined the Finnish leftist intellectuals and communist activists from the 1930s until the 1960s. Her research has covered different sources from diaries, fiction, poetry, journalism to surveillance material. Her various articles from the end of the 1990s up until the 2010s have been published as an anthology, see Koivisto 2011.

${ }^{17}$ Rafeek 2008.

${ }^{18}$ Oredsson 2001, 191-205. 
the Communist Party. She is also seen as a busy agitator. Sources of this kind have primarily been used, in a Swedish context, as a means of studying surveillance methods used by the Secret Police. ${ }^{19}$ It is obvious that the notes represent the Secret Police's view of the world. However, when I read them, not only from a suspicious perspective but from a political agency perspective, patterns of political activities emerge.

The material in Valborg Svensson's personal files in the Secret Police archive consists of 260 items in four volumes from the years 1930-1964. The files reveal identification inquiries, travels, presence at meetings, speeches, behaviour of audiences, political activities in Communist newspaper articles, and a few private circumstances. ${ }^{20}$ According to the documents, Valborg Svensson was offered several places for political meetings around Sweden. Movements within the country, mostly in the north, are in focus. The first meeting noted is a May Day meeting: 'Spoke in Karlshamn 1/5-33.' She also spoke in another city in southern Sweden on that same day. She had already spoken at the International Women's Day event in Stockholm on 8 March, and she then left for a four-day meeting tour in northern Sweden. Several notes on similar meetings are repeated during the 1930s. However, at the beginning of the Second World War, the attention of the Secret Police increased when Valborg Svensson went on a two-week tour in the north and held twenty meetings in which she encouraged housewives to join the Communists. The Secret Police followed her agitation in Stockholm on 8 March and at other large meetings in the city, one with 675 persons. ${ }^{21}$

These scattered documents tell stories about Valborg Svensson being an active agitator. The files give information on how she made use of the space; that she mostly spoke to women about women's issues. She met them in special women's campaigns and raised issues such as housing, food supply and women's input in industrial work. She gave speeches to tenants, to newspaper delivery women, in several election campaign

${ }^{19}$ Andersson 2014; Gustavsson 2011.

${ }^{20}$ VS, P 2263. T:1, consists of 45 articles, two from the newspapers Dagens Nyheter and Expressen.

${ }^{21}$ VS, P 2263. A:1, report 21, 22, 24, 25, January and February 1941, report 27, Ny Dag 10.3.41, report 30 May 1941, report 50, September 1942, and report 55, January 1943. 
meetings, against war in antifascist meetings, in study circles, and at different celebrations, such as the October Revolution (16th) in November 1933 and Komintern (15th) in March the following year. The Secret Police noted another gendered place for her political activism, namely the position as editor for the 'Working women's paper'. Already in 1934, she was offered a place on a list of candidates for the Stockholm City Council and on a list for the church council in a parish in Stockholm.

Documents about her private life, including contacts with Scandinavian Communists and travels in and out of the country, tell stories about both boundaries and possibilities. The places offered by the Communist Party are political courses in Moscow, but the Secret Police focused on Svensson's romantic relationship with a central Communist activist in Scandinavia. In the files, her contacts are viewed as the dangerous issue, and nothing is mentioned regarding the content of the schooling. ${ }^{22}$ Identification notes regularly confirm her name and date of birth, housing, work place, salary, and possible cover names. Even before Moscow she was seen as a threat due to her international contacts. Early reports note that as a maid in the household of a lieutenant-colonel, she displayed exemplary behaviour; she was talented at speaking German, she sold Communist papers, she invited other maids to political meetings, and she met with a German man who offered her to go to the Soviet Union for training. ${ }^{23}$ Four years later, extracts from reports and letters indicate that Valborg Svensson should be watched closely, because she worked as a contact between the red Finns in Karelia and Russia and their friends in Sweden and Finland. ${ }^{24}$

In the 1930s, the Secret Police raise questions concerning her marital status. It begins in 1932 with the statement that Valborg Svensson is married to Arvid G. Hansen. Notes in telegraphs regarding travels, both to and from Russia, show her possibilities to meet with contacts abroad: 'Arrived to Stockholm from Russia 10.2.33' and '[d]eparted from Sthlm

\footnotetext{
${ }^{22}$ Hansen (1960) 1998.

${ }^{23}$ VS, P 2263. A:1. 4-6, reports dated 12.11.30. In report 3, the same date, a newspaper with a photo of the women delegation to Russia is said to have been included.

${ }^{24}$ VS, P 2263. A:1. 8-10, reports, September and October 1934.
} 
to Russia 18.8.33'. ${ }^{25}$ The files report her travels both to Russia and Norway and back to Sweden around 1935. Someone claims that she is divorced in 1934, but two years later, when she travels to Oslo to live with Hansen, he is described as the one 'to whom she is married'. For the next year she lives in Bergen with Hansen and continues to participate in election meetings, women's courses, and tours in Sweden. ${ }^{26}$ In 1939, a report states that Hansen lives in Stockholm with his fiancé, Valborg Svensson. ${ }^{27}$ The question of her being married or not is once again an issue when her name is placed on the City Council list, and the Secret Police wonder whether she will '.. describe herself as Miss or Mrs? ${ }^{28}$ It seems she had frequent possibilities to use political space in full. Despite the surveillance and her unsolved marital status, she was able to travel, live in different places and work in politics in Sweden.

During the Second World War, Valborg Svensson engaged in other politically gendered places and spaces. The Secret Police found a statement she wrote in the Communist paper $N y$ Dag [New Dawn] about helping children in Leningrad. ${ }^{29}$ In the Stockholm City Council, she became one of thirteen experts on the temperance commission in $1944 .{ }^{30}$ During the 1950s, she entered a new gendered position when she joined the women's leftist federation SKV that welcomed also Communists. The Swedish section was related to the international WIDF. Between 1948 and 1952, the federation grew, because several new local

25 Arvid G Hansen (1894-1966), leader of the Scandinavian federation of Communist parties in 1924 . He edited several papers and periodicals, was 1931-1935 in the Soviet Union responsible for educating agitators from abroad. After returning to Norway 1936, he edited Arbeidet, but had no longer the same position in the Communist Party as in the 1920s. He was expelled in 1949. Hansen lived in exile in Sweden 1940-1945. See Hansen, (1960) 1998; http://en.wikipedia.org/wiki/Arvid_G._Hansen.

${ }^{26}$ VS, P 2263. A:1, data on activities 1937 and 1938, in the first pages of the act, without numbers.

${ }^{27}$ VS, P 2263. A:1, data from the passages above are placed in the first pages of the act, without numbers. On leaving the editor job, see Hermansson 1977, 129, an interview with Fini Smålan.

${ }^{28}$ VS, P 2263. A:1, 36, report dated 8.1.42. It was Miss (fröken) Valborg Svensson, Tomson 1964, 89-90.

${ }^{29}$ VS, P 2263. A;1, report 59, Ny Dag 22.10.43.

${ }^{30}$ VS, P 2263. T, 3, Ny Dag 23.11.44, and 4, Expressen 5.12.44. 
associations were founded. The Secret Police became suspicious and collected altogether 23 volumes of data on SKV. ${ }^{31}$ It was not a problem for the Communist Party that Valborg Svensson joined SKV, and she was still allowed to work within the Party. Together with her membership in the Party's central committee, her travels to WIDF's secretariat in East Berlin and her position on the board of SKV are noted in the files from the 1950 s. ${ }^{32}$

Communism and women's issues a contested area during the 1970s

In the 1970s Valborg Svensson was interviewed by C.H. Hermansson, a former leader of the Swedish Communist Party, for his book Kommunister. En intervjubok av CH Hermansson. Första boken. The printed interview in general could, to some extent, be interpreted as a defense act, since Valborg Svensson was asked to compare women's political work in the Communist movement before the Second World War with the new women's movement, and she has a different standpoint than the interviewer. Altogether, Hermansson's two books report interviews with 33 men and 9 women. Even though the respondents spoke rather freely about their memories, the main interest for the interviewer was to highlight Communist identities and experiences as activists. In the case of Valborg Svensson, her participation in SKV, seen as either co-operation with liberal and Social Democratic women or as an aspect of the new women's movement, was also problematised. ${ }^{33}$

In the interview, Valborg Svensson refers to ironing at a textile factory as a place for political work. At the same time, she indicates that she has been interviewed for a theatre manuscript: 'I don't know if you have seen the play Jösses flickor. There is a girl who pulls and draws

${ }^{31}$ Andersson 2014.

${ }^{32}$ VS, P2263. A:2, report 144 and 145, May and July 1953. A:3, report 254, May 1964, report 205, December 1957.

${ }^{33}$ Extracts from his interview with Svensson was published in Vi Mänskor, SKV, $75^{\text {th }}$ jubilee, Hermansson, 1989, 2-3. 
[the shirt collar] like this. That is how we did it. ${ }^{34}$ Descriptions of hard work, of heavy ironing machines, of sunshine through large windows in the summer, of low wages, and of her attempt and failure to organise a union are included in the interview. Valborg Svensson recounts that it was her uncle, a member in the Communist Party, who told her to join the youth club after a dance at the People's House. In this new political space, she learns how to do political work and begins eagerly selling papers, collecting money and working in election campaigns. In a few sentences, and without any details, she covers her stay in the Soviet Union, her editing work, and her membership in the Communist Party's central committee. She mentions living in Norway (1936-1938), but does not reveal the name of Arvid G. Hansen.

Two other questions are important to C.H. Hermansson. One of them is whether she had problems working for so many years in SKV with women of different political affiliations. Valborg Svensson takes the opportunity in the interview to talk about her experiences of political agency. She explains that she met these women in the committee for Children of Leningrad, where Social Democratic women, the cooperative movement, unions, and Social Democratic youth clubs participated, and that SKV has meant a lot to her because of its international solidarity work. The other question C. H. Hermansson raises is about comparisons between the women's issues in the Communist movement and the new women's movement. He refers to the hard work Valborg Svensson did during the 1930s in terms of the women's paper, activist meetings, courses, and conferences. She clearly views gender within her place and space in a different way than he does as she refers to the differences between the past and the present, and she sees possibilities in the new women's movement. She confirms her past activities and adds that the women's paper published 14,000 copies per month between 1933 and 1948. Although both men and women participated in political work and theoretical studies before the Second World War, she emphasises the fact that, in the 1970s, there are new, interesting books on young working-class women's problems. Her standpoint is that women's issues are nearly the same as in the 1920s and 1930s. She states that even

\footnotetext{
${ }^{34}$ Hermansson 1964, 236.
} 
Alexandra Kollontay is read in the new women's movement, and she ends by saying that to work against capitalism and women's oppression is not new.

\section{Fictional voices about women's political work in history}

The aim of the theatre manuscript Jösses flickor! Befrielsen är nära, en politisk förening 1924-1974 [Oh, dear girls! Freedom is close, a political association 1924-1974] written by Margareta Garpe and Suzanne Osten, was to mediate historical experiences about women's political work and bring it into the new women's movement. In the 1970s, such work was unknown, but many of the old activists were still alive and shared their memories in interviews with the writers. These recollections and archival studies of the women's organizations resulted in a fictional theatre manuscript. In 1974, the play was staged at the City Theatre, a publicly funded cultural institution in Stockholm, and the manuscript was published three years later. Although it is a work of fiction, a number of references link to parts of SKV's history. Names of real members in the association are occasionally used as points of reference. ${ }^{35}$ In the manuscript, some of Valborg Svensson's memories are especially incorporated into one central character, Ragnhild; this becomes evident when reading the surveillance material. Ragnhild represents an experienced political activist and is described as uncompromising, classconscious, loyal, and true to her visions and choices. The play also portrays her relationship with a Norwegian Communist, Halvdan. ${ }^{36}$ The manuscript consists of two acts, divided by the Second World War, with 29 scenes altogether.

In Jösses fickor! Ragnhild enters the second scene as an ironer in a textile factory, a gendered workplace that was also a place for protests. This is the scene where Ragnhild and another girl are steam ironing and pulling shirt collars, trying to make them fit. They are tired of customers

\footnotetext{
${ }^{35}$ Johansson describes research for the manuscript: Johansson 2006, 152-153, 157.

${ }^{36}$ Garpe and Osten 1977.
} 
who do not know the collars are too small and even shrink. The girls protest, demand their salary and abandon their work. They stop at the People's House, a place for political mobilization, when they hear music coming from within. 'It is the Communists. Dare we go?' Ragnhild asks. After a political speech and dancing, Ragnhild is enthusiastic, and, with flyers in her hand, she wonders if there are Communists in Stockholm. ${ }^{37}$ In scene four, Ragnhild has joined the Communist Party. ${ }^{38}$

In another scene, a new gendered place for protest actions is introduced. It is a butter shop with low wages and no overtime pay. Ragnhild fights for an agreement on wages and working times, but she fails and is dismissed. ${ }^{39}$ In the next scene, Ragnhild, who is pregnant but not married, is lying down because the illegal abortion went wrong. There is no time for her to rest. She is going to the Soviet Union to meet her comrades. ${ }^{40}$ Later, a postcard arrives from Ragnhild, who is in the Soviet Union: 'Equality between the sexes, women having both work and kindergartens. Soon it will be a paradise. Fascism in Europe, Stalin will defend peace. ${ }^{31}$ In the manuscript, the place (the Soviet Union) is gendered due to the equality between women and men.

Back in Sweden, Ragnhild is selling a Communist paper. She has met a Communist comrade in the Soviet Union, Halvdan from Trondheim, who offers her love and a place with him..$^{42}$ In another scene, Ragnhild is in Norway interacting with a female journalist from Sweden, who is visiting to write about the occupation. The journalist and Halvdan take an interest in each other. Jealousy is discussed, but Ragnhild does not think he will betray her. They are comrades, and the needs of the movement must be central, she states. Ragnhild writes for a women's paper and although she works in the Norwegian Communist Party, she longs

\footnotetext{
37 Scene 2: 'The ironing section', Garpe and Osten 1977.

${ }^{38}$ Scene 4: 'Unemployment', Garpe and Osten 1977.

39 Scene 7: 'The Butter shop "Ahaed", Garpe and Osten 1977.

${ }^{40}$ Scene 8: 'The waiting room', Garpe and Osten 1977.

${ }^{41}$ Scene 10: 'Association “Jösses flickor”, 1936', Garpe and Osten 1977.

${ }^{42}$ Scene13: 'Ragnhild chooses Norway', Garpe and Osten 1977.
} 
for real work. ${ }^{43}$ In Norway, she uses her possibility to engage politically, but when the Swedish Communist Party needs her, she returns. ${ }^{44}$

After the war, the manuscript states that new gendered places were offered to her. An exhibition for Children of Leningrad is commented on by Alexandra Kollontay, who expresses friendship between the Swedish and the Soviet people. Ragnhild attends a WIDF conference in Sweden, where even Social Democratic women are able to participate. She is impressed that 80 million are working for peace and justice. ${ }^{45}$ One part of the gendered space in the manuscript is filled with international contacts and solidarity work and another with dividing comradeship boundaries within the romantic relationship. Since Ragnhild is doing her work in Sweden, Halvdan has decided to work in Norway and to marry a Norwegian comrade who is pregnant. Ragnhild feels not betrayed but disappointed. They stand on different barricades, but for a common fight. 'I could move to you, but you did not want to move here. A female comrade can't succeed,' she explains. Ragnhild is not a victim; she has made her own choices for something larger, such as solidarity. ${ }^{46}$ The next time Ragnhild shows up, she prints flyers against the atomic bomb and French troops in Vietnam. ${ }^{47}$ She is enthusiastic to help women and children in Vietnam. ${ }^{48}$ Ten years later, Ragnhild seeks to change the name of SKV's periodical to 'We people' and invite a new women's group to SKV's 50 year jubilee. ${ }^{49}$

${ }^{43}$ Scene 15: 'War report in Norway', Garpe and Osten 1977.

${ }^{44}$ Scene 16: 'Ragnhild is back home', Garpe and Osten 1977.

${ }^{45}$ Scene 18: 'Association “Jösses flickor” 1946/47', Garpe and Osten 1977.

${ }^{46}$ Scene 22: 'Separate ways 1948', Garpe and Osten 1977.

${ }^{47}$ Scene 23: 'The woman in the shadow of the bomb 1953', Garpe and Osten 1977.

${ }^{48}$ Scene 26: 'The painful women question 1962', Garpe and Osten 1977.

${ }^{49}$ Scene 27: 'The association “Jösses flickor” 1973', Garpe and Osten 1977. 


\section{Remembering actions in the radio interview}

Valborg Svensson is 80 years old, in 1983, when the radio interview about her being an International Women Day's 'veteran' is broadcasted. The interviewer asks her to comment on her own history as a political activist. She remembers speaking in 1933 in a central square (Stortorget) in Sweden's capital, Stockholm. This is confirmed in the Secret Police files: 'Spoke at Stortorget the 8/3-33.' In the interview, Valborg Svensson speaks seriously with a sense of humour when she describes how she filled the space in spite of the circumstances. The platform was not lit and the loudspeaker did not work, so she had to speak as loud as she could about the threat of war and hard times, and all without any manuscript.

International Women's Day was celebrated in the 1930s, but during the war, it was impossible to have big meetings, she recalls. However, in the Secret Police files on Valborg Svensson, stories about her political agency as a speaker are reported from several meetings, at least between 1941 and 1943. In 1946, the celebrations started again with protests against Stockholm Tramways. The company was looking for young men to work as engine drivers and conductors, jobs women had held and been revered for during the war. Now women were no longer wanted. 'We got furious,' Valborg Svensson states. A large protest meeting was arranged, after Women's Day, and both women and men participated. The demonstration is not recorded in the Secret Police files on Valborg Svensson. Once again, an action took place in Stockholm in the form of a protest meeting concerning a conflict at work that was clearly gendered.

\section{Conclusion}

The sources I have worked with in this chapter, especially the theatre manuscript and the interviews, have challenged me in two ways. I needed to decide how to show that these sources were aimed at identity production in public arenas during contemporary times. I also sought 
to give meaning to the images linked to Valborg Svensson in biographical writing. Even in her seventies and eighties, she participated in the creation of documents by telling historical narratives connected to her. That is one way of using the sources. The only documents she could not influence are the files in the secret kept surveillance acts. In spite of that, all four sources are possible to be read as interrelated and connected to one another in different ways. In the printed interview, stories are told about the theatre manuscript. Data in the surveillance files verify the stories in the theatre manuscript and in the radio interview. When viewed together, I see them as documents of life or pieces of a puzzle that shaped subjects with political agency, as told through the voices of others within different frameworks. I have found images of a busy activist dedicating herself eagerly to Communist activism, a confident defender of political experiences in discussions of women's issues before and after the Second World War, a fictional character claiming her right to have visions and a veteran proudly taking part in demonstrations. The produced images of Valborg Svensson are valuable in depicting the political and cultural landscape.

Are place and space helpful when mapping out patterns of political agency? Are the concepts useful as analytical tools for examining possibilities and boundaries for gendered work in a political movement? Even if I don't have a full answer to those questions, I have identified place and space, and some boundaries and possibilities for gendered political agency. The Communists' activities posed a threat to national security. The surveillance files recognised the places of political mobilization. These places were also offered to female comrades and used by them, enabling them to contact with the Communists of other nationalities, and sometimes even to form undefined intimate relationships. In the theatre manuscript, the political work occurred in gendered workplaces, and was reflected within visions of comradeship between men and women, and gender equality that was imagined to be reality in the Soviet Union. Furthermore, international solidarity work was presented as a place of political agency. In the radio interview, the movement was reported to have taken place in public squares in forms of meetings or demonstrations and as a conflict related to gendered work. One essential aspect of the space is the way how it was connected to and used for 
agitating and editing work, speaking tours, social political community work, solidarity work for women and children, international women's organization, the new women's movement and International Women's Day. It was within this pattern of told stories of gendered places and spaces that Valborg Svensson, as an entrepreneur of ideas, carried out her gendered political agency.

\section{Bibliography}

\section{Archival material}

The Swedish Radio Company, programme 1.

Interview with Valborg Svensson. Broadcasted 1983-03-08.

Säkerhetspolisens arkiv (The Secret Police archive), Stockholm.

Svensson, Valborg, Personakt 2263, 4 volymer.

Arbetarrörelsens arkiv och bibliotek, ARAB, Stockholm.

Svensson, Valborg, Reference code 563, vol:1.

\section{Other sources}

Arbetarkvinnornas tidning, Sveriges kommunistiska parti, (Stockholm, 1930-1947).

Garpe, Margareta and Osten, Suzanne: Jösses flickor! Kärleksföreställningen. Två kvinnopjäser (1977) Gidlunds förlag 1977 (Includes the manuscript Jösses fickor! Befrielsen är nära, en politisk förening 1924-1974).

Hermansson, C.H.: Kommunister. En intervjubok av CH Hermansson. Första boken. Lund, Arbetarkultur, 1977.

Hermansson, C.H.: Flera sekel av kvinnokamp. Vi Mänskor 2-3/1989.

Palmaer, E.: Valborg Svensson är död. Vi Mänskor 3/1983.

Palmaer, E.: Hon talade med hjärta och hjärna. Vi Mänskor 2-3/1989.

Svensson, Valborg: Arbetarkvinnor!: med vem röstar ni? Arbetarkultur, Stockholm 1934a.

Svensson, Valborg: Arbetarkvinnorna inför ett nytt världskrig. Arbetarkultur, Stockholm $1934 \mathrm{~b}$.

Svensson, Valborg: Ett ord till husmor. Arbetarkultur, Stockholm 1942.

Svensson, Valborg: Ett allvarsord till kvinnorna! Arbetarkultur, Stockholm 1940.

Tomson, Ragnar: Etik och Politik. Etiskt-kulturellt-socialt initiativ i Stockholms stadsfullmäktige àren 1900-1950, Band III 1941-1950. Stockholm, 1964.

Tomson, Ragnar: Femtiotalet i Stadshuset. Med särskild hänsyn till kulturella och sociala frågor $i$ Stockholms stadsfullmäktige åren 1951-1959. Stockholms Stadsarkiv, Stockholm 1966.

\section{Literature}

Andersson, Irene: Vi Kvinnor - Vi Mänskor - en farlig tidning? New voices. 150 years of women periodicals in Sweden. Ed. Anna Nordenstam. University of Gothenburg, Gothenburg 2014, 155-172. 
Ambjörnsson, Ronny and Sörlin, Sverker: Obemärkta. Det dagliga livets idéer. Carlssons förlag, Stockholm 1995.

Enke, Anne: Finding the movement. Sexuality, Contested space, and Feminist Activism. Duke Univerity Press, Durham 2007.

Brink Pinto, Andrés: Med Lenin på byrån. Normer kring klass, genus och sexualitet $i$ den svenska kommunistiska rörelsen 1921-1939. Pluribus, Lund 2008.

För Spanien 1936-2011. Till 75-årsminnet av antifascistiska solidariteten med Spaniens folk. Arbetarnas Kulturhistoriska sällskap, AKS, Arbetarrörelsens arkiv och bibliotek, ARAB, Svenska Spanienfrivilligas Vänner, SSV, Luleå 2011.

Gogman, Lars: From Women's club to Group 8. The Separate Organization of Women within the Swedish communist Movement. Arbetarörelsens Arkiv och bibliotek, Stockholm 2010.

Gustavsson, Martin: Med säkerhetspolisen hack i häl. Siri Derkerts samhällsvetenskapliga studier och politiska engagemang i freds- och kvinnorörelsen 1940-1955. Att alltid göra och tänka det olika. Siri Derkert i 1900-talet. Eds. Mats Rohdin and Annika Öhrner. Kungliga biblioteket, Stockholm 2011, 135-181.

Gunnarsson, Evy: Med nål och garn för socialismen. De kommunistiska kvinnornas kamp 19191947. Värnamo, Arbetarkultur, 1977.

Hansen, A. G.: Kaderudanningen i Moskva. Arbeiderhistorie. Arbok for. Arbeiderbevegelsens Arkiv og Bibliotek, Oslo 1998 (1960), 54-62.

Holgersson, Ulrika: Att leva som kvinna i Lund: från 1862 och framåt. Lunds historia staden och omlandet. 3. Modern tid. Där tankar möts (1862-2010). Ed. S. Oredsson. Lunds kommun, Lund 2012.

Johansson, Birgitta: Befrielsen är nära. Feminism och teaterpraktik i Margareta Garpes och Suzanne Ostens 1970-talsteater. Symposion, Stockholm/Stehag 2006.

Johnson, Louise C.: Replacing gender? Reflections on 15 years of Gender, Place and Culture. Gender, Place \& Cultur: A Journal of Feminist Geography. 15:6 (2008), 561-574.

Koivisto, Hanne: Politiikkaa, erotiikkaa ja kulttuuritaistelua - Kirjoituksia suomalaisesta vasemmistoälymystöstä 1930-luvulla. Työväen historian ja perinteen tutkimuksen seura, Helsinki 2011.

Kotila, Pirkko: Hertta Kuusinen — The 'Red Lady' of Finland. Science \& Society. Special Issue: Biography Meets History: Communist Party Lives in International Perspective. 70:1 (2006), 46-73.

Maynes, M. J., Pierce, J. L. and Laslett, B.: Telling Stories. The use of personal narratives in the social sciences and history. Cornell University Press, London 2008.

Moi, Toril: Simone de Beauvoir. Hur man skapar en kvinnlig intellektuell. Symposion, Stockholm/Stehag 1996.

Oredsson, Sverker: Svensk rädsla. Offentlig fruktan i Sverige under 1900-talets första hälft. Nordic Academic Press, Lund 2001.

Rafeek, Neil C.: Communist women in Scotland: red Clydeside from the Russian Revolution to the end of the Soviet Union. Tauris Academic Studies, London 2008.

Staeheli, Lynn A.: Mobilizing Women, Mobilizing Gender: is it mobilizing difference? Gender, Place \& Culture: A Journal of Feminist Geography. 11:3 (2004), 347-372.

Stanley, Liz (ed): Documents of life revisited. Narratives and biographical methodology for a $21^{\text {st }}$ century critical humanism. Ashgate, Farnham 2013.

Östberg, Kjell: Efter rösträtten. Kvinnors utrymme efter det demokratiska genombrottet. Brutus Östlings förlag, Stockholm/Stehag 1997. 
RELATIONS 


\title{
Remembering mother: \\ Relations and memory in the biographical project on Minna Krohn (1841-1917)
}

\author{
Maarit Leskelä-Kärki
}

Biography will enlarge its scope by hanging up looking glasses at odd corners. And yet from all this diversity it will bring out, not a riot of confusion, but a richer unity. ${ }^{1}$

This chapter is about contradictory and relational narratives. I will analyse the ways individuals are described, written about and remembered within their close relations and ask, how we, as biographers, could make use of the varied and often also conflicting material produced on past persons. In this case, the material is both visual and textual, both fictional and documentary. The underlying idea will be to question the idea of a coherent life-story, 'a life as a given entity'2. Following the above notion by Virginia Woolf's famous essay 'The Art of Biography', I examine how various looking glasses could perhaps help us in encountering the unknown past persons and act as paths towards the past persons in a way that would allow many voices and contradictions.

\footnotetext{
${ }^{1}$ Woolf 1942 , electronic source.

${ }^{2}$ Brockmeier 2001, 247.
} 
I will start by showing one 'odd corner' of my study: a painted portrait depicting the main character of my research. In 1888, the Finnish painter Maria Wiik painted a portrait of Minna Krohn, the former school mistress of the Finnish Girls' School in Helsinki. The portrait was among the many official portraits painted of the school's directors. Although the portrait could be looked at merely as an official portrait painted within the boundaries of the conventions of official portraits, I will, at the conclusion of this chapter, stretch its boundaries a bit further and discuss the possible ways it could be used as part of a biographical analysis on Minna Krohn's life. Before this, I will contrast the painting with some textual narratives, other 'odd corners', produced on her, and see what these diverse corners might convey to a biographer. My focus will be on the different relations surrounding Minna Krohn during her lifetime, and I will use Adriana Cavarero's idea on relational identity as a starting point. I aim to show how a biography can be written from the perspective of various, conflicting narratives surrounding the individual. In this, my chapter closely discusses with Birgitte Possing's contribution, where she illuminates the methodological paths on how she decided to construct a polyphonic portrait of Danish politician and minister Bodil Koch.

\section{Silenced figure - or not?}

To begin with, Maria Wilhelmiina Lindroos (later Minna Krohn, 1841-1917) could be presented as a forgotten and, in part, also mishandled figure of the influential Krohn family - she was not a famous or heroic figure befitting of the canon of those generally written about in biographical form. She was born in a modest, lower middle-class, Swedish-speaking family, where her father was a self-taught man, who also wanted to educate his daughters. From a nationalistic and religious background, Minna Lindroos became educated as a school teacher, and was later appointed as the director of the first Finnish-speaking girls' school in Helsinki. Eventually, she married a famous professor, poet and nationalist Julius Krohn, who had just lost his wife, and became mother 


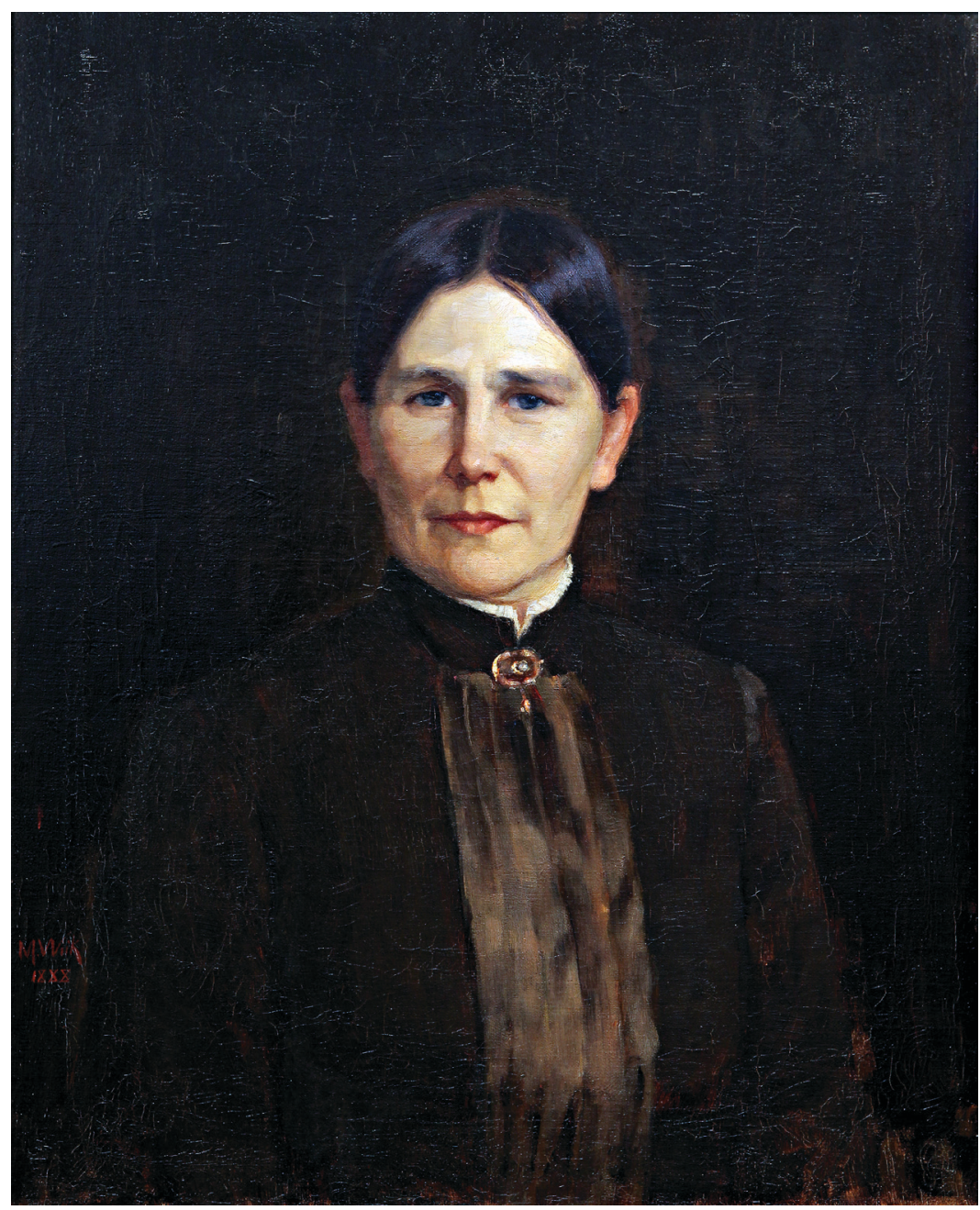

Portrait of Minna Krohn, Director of Finnish Girls' School in Helsinki. Painted by Maria Wiik 1888. (Helsinki University Museum)

to three stepchildren and two biological daughters. Widowed in 1888 and suffering from depression, which evolved into severe depression for nearly the last two decades of her life (1900-1917), she hardly seems to be a figure worth a heroic biography. Yet, she had been educated abroad, 
belonged to the first generation of girls' school teachers, worked among the nationalist (Fennoman) circles (later becoming part of a Finnishspeaking nationalist home after marrying Julius Krohn), and as a school director before her marriage as well as wrote poems and children's stories and edited a children's magazine Pääsknnen. For a researcher, her life seems to be full of conflicting aims and circumstances.

During the process of writing my earlier research about the Krohn sisters, it became obvious that the sisters' mother was a complex character in their lives. She was not so much a strong, encouraging mother, but a very contradictory and tragic figure. The sisters shared the same father in professor, poet and nationalist activist Julius Krohn, but they had different mothers. The eldest, Helmi Krohn (1871-1967), was from Julius Krohn's first marriage to Emma Krohn. There were also two older boys, Kaarle and Ilmari, from this marriage. Emma Krohn died in 1874 when Helmi was three years old, and soon after, her father remarried with a family friend, Minna, and they had another two daughters, Aino (1878-1956) and Aune (1881-1967).

Each of the sisters had a unique and difficult relationship with their mother. Aino and Aune faced their mother's mental unbalance from quite early on, since Julius Krohn died accidentally in 1888, when Aune was only seven years and Aino ten years old. After that, Minna Krohn's health never recovered and she visited hospitals occasionally. At the turn of the century, her depression became more severe, and in 1900-1917, she spent most of her time in bed at home or in mental hospitals. As the youngest of the sisters, Aune Krohn was yet unmarried, and it was agreed that she would be suitable for taking care of their mother. She lived with Minna Krohn (together with changing nurses) until her mother died in 1917, and suffered, herself, from depression occasionally. Thus, Aune Krohn's relationship with her mother was the most intimate one, and she had to cope with the mother's illness most severely. For Aino Kallas, her mother's mental illness was difficult to cope with and, when she moved abroad after her marriage to Estonian Oskar Kallas in 1900, her relationship with her mother became characterised by guilt for not being around there for her in Helsinki. For Helmi Krohn, Minna always remained a stepmother, and the tragedy of losing her own mother followed her throughout her life. 
My starting point for the biography project is the multi-layered biographical material that the sisters produced on their mother. ${ }^{3}$ Although it seems at first glance that their mother was a forgotten and silenced figure, she was actually much discussed and debated, and thus remembered, by her daughters in their mutual correspondence. They all also wrote about their mother; Aino Kallas and Helmi Krohn wrote about her in a novel and Aune Krohn in a memoir book and some articles. The relations and dynamics between the daughters and the mother are of most importance. Minna Krohn's case seems to offer a fruitful basis for studying how life-stories are constructed in different forms of remembrance and how they are, thus, deeply relational.

\section{Relations}

In terms of relationality, I refer to Italian philosopher Adriana Cavarero's ideas on relational identities. Cavarero has inspired many feminist scholars with her ideas on relative narratives originating from her book Relating narratives (2001). ${ }^{4}$ Cavarero points out how identity does not reveal a deepest intimate self-identity, it only expresses what is being performed, since 'one always appears to someone': 'Who each one is, is revealed to others when he or she acts in their presence in an interactive theater where each is, at the same time, actor and spectator.' Referring mostly to autobiographical narration, she claims how our identity comes into being through exposure and relation to others, from the outside and through the stories that others tell. Thus, we could also see her defending the biographer and the overall process of narrating a life, as she points out how every life becomes justified through the act of nar-

${ }^{3}$ This chapter does not intend to cover all the possible material that can be used in this biographical research. There are also other materials, such as correspondence between the two stepsons, as well as between the married couple and other textual material on Minna Krohn. Due to limited space, I will mostly concentrate on the relations between mother and daughters.

4 See Cavarero 2000 24-33. See also e.g. Jansdotter 2008; Leskelä-Kärki 2008, 2011; Tamboukou 2010a, 2010b; Liljeström 2012. 
ration. ${ }^{5}$ In this biographical research, I will try to follow Cavarero's ideas in analysing the different narratives constructed on Minna Krohn. They are all equally important for me in trying to capture something valuable of her life, her identity and her 'after-image'.

Sidonie Smith and Julie Watson have argued that relationality is still one of the most important concepts of autobiographical or life-narrative studies. The relationality of a subject can be seen as the core existence of our psychic life, narrative encounters and whole of our humanity. ${ }^{6}$ When we look at one individual life as related to other people and networks of people, we get a much richer and more contradictory picture. This perspective shows how one life is never to be told as a whole, but that it consists of changing perspectives, changing relations and different situations, which form our lives, taking us in, sometimes, unexpected directions.

Relationality happens, also, in the close relationship between biographer and the one he/she writes about. We encounter people from the past through the sources they have left, by chance or through a conscious effort to preserve. Either way, the sources we have are always partial and limited.7 As the biographer is dependent upon the source material, we could say that our interpretations are already constructed and filtered because of these archival processes. This is why the relationality between the one who narrates and the narratee is so vital. This interaction happens during the research process and, thus, we could see that writing a biography is also about acknowledging and reflecting on this interaction. In Cavarero's words, we come to understand the uniqueness of every life-story. ${ }^{8}$ As biographers become deeply involved with past lives, they become interpreters, actors, close bystanders, who also become affected by the stories they read and by the interpretations they construct.

5 Cavarero 2000, 11, 24-27, 34, 81-93.

6 Smith and Watson 1998, 2010.

7 About archival processes, women's archives and the multiple ways an archive can be shaped before a researcher even has an access to it, see for example Dever, Vickery and Newman 2009, 3-35.

${ }^{8}$ Cavarero 2000, 32-45. 
In the biographical project concerning Minna Krohn, relationality refers both to the actual relations that Minna Krohn had, in this case, particularly, with her daughters. It could also be viewed, however, from a more abstract perspective concerning the different places in which she has been narrated, including her daughter's textual archives (fiction, letters, articles, memoirs) and other relatives' memoirs, as well as in other forms, including the portrait painted of her or the photographs taken of her. What is left from Minna Krohn are precisely stories. Stories that not only tell about her but also about the history of daughters and mothers, the history of women's societal activity in the nineteenth century and the history of women's mental illnesses. Getting close to Minna Krohn's life means admitting the necessary value of these stories as part of the larger picture of women's history.

Except for the writings of her daughters, there have never been any published texts or biographies on Minna Krohn. The figure of the withdrawn mother has remained powerful, for example, in the narratives on the life of her famous daughter, writer Aino Kallas or the influential Krohn family. Only in 2005, when Pertti Lassila published a biography on Julius Krohn, did a new image of Minna Krohn start to appear. He pointed out that although their marriage was not a romantic affair, it could be regarded as a happy and equal marriage of two like-minded individuals. ${ }^{9}$

The daughters narrated their mother's life in various genres: in letters, fiction, diaries, memoirs, as well as in documentary and biographical texts. I am interested in the different narrative identities that were articulated in their various textual materials, both published and unpublished, and how the daughters thus participated in the construction of the life-story of Minna Krohn. There is also the narrative that is constructed in the autobiographical material of Minna Krohn, which I will, in the following, discuss as well. The web created by these different textual and visual narratives, their relations, clashes, sameness and differences, will be the main focus of the future biographical research.

\footnotetext{
${ }^{9}$ Lassila 2003, 83-85.
} 


\section{Fictionalised mother}

First, I will examine the two narrative images constructed of Minna Krohn in fiction, written by her daughter Aino Kallas and stepdaughter Helmi Krohn.

Helmi Krohn was 36 years old when she started writing her fifth novel about her family history and the old family mansion, Kiiskilä, in Viipuri. The central figure in her novel Vanhan kartanon tarina [Tale of the Old Mansion, 1907] is Eva Manner, a nurse who marries Doctor Erik Leopold and steps, as an outsider, into the life of his distinguished family and their mansion. The novel concentrates on the contradictions and conflicts Eva has to confront in her new surroundings. Eva's ideas of family life and the connection between a husband and wife do not correspond with the old, conservative ideals of a collective and patriarchal family. Eva represents a more modern female type, who is contrasted against Erik's dead wife, the idealised Anna. Eva's loneliness in the mansion and among the family is described as a painful experience, and it makes Eva age rapidly. Her experiences squash her joyful trust in life, and her own feelings of power, and she even starts to regret her decision to marry Erik. Eva Manner's character analyses the possibilities of a modern woman, the changing roles of husband and wife, and the rupture of old, patriarchal family ties.

Focusing on Eva and her life-story right from the beginning, the sympathies of the readers are on Eva's side. The narrator describes Eva, when she enters the family mansion with her husband, as follows:

A happy smile made her slightly sharp face more beautiful, and that inner light that flowed from her eyes and circled her changed her somewhat ordinary face into an almost beautiful vision. The near ascetic simplicity and strictness, which was so characteristic of them, dis- 
appeared. And a youthful, almost childish expression appeared, an expression that had been rare even in her youth. ${ }^{10}$

Read against the family background and Helmi Krohn's own experiences as a stepdaughter, the novel is surprising as it empathises with Eva Manner and shows her tragic destiny as understandable. It feels as though Helmi Krohn would have tried, through her novel, to find psychological and social reasons for their family dynamics and for Minna Krohn's illness. Her novel could be analyzed as a fictional and psychological biography of Minna Krohn, as her focus stays on Eva throughout the book, albeit intertwined with another central figure, namely Eva's stepdaughter Siiri. This is also interesting with regard to Helmi Krohn's own literary career, as she published only one more novel after this one and then turned to writing biographies during the 1910s and 1920s. Later, she wrote about Minna Krohn in her biography on her father Julius Krohn (1942), and also in a diary novel for young girls, Eeva-Liisa, that depicted her own childhood and youth.

Aino Kallas published her novel Katinka Rabe in 1920 at the age of 42. This novel is a special one among Kallas' works, as it is one of the two literary works in her wide repertoire since 1900 that did not deal with Estonian history, culture and folklore. It is a strongly fictionalised, impressionistic novel about a young girl Katinka Rabe, her childhood and her relations with the family heritage, her father, mother and the Rabe family. The novel has been seen as an impressionistic one, as it is fragmented, lyrical and subjective. It has also been analysed as an autobiographical novel and an artist novel that discusses women's possibilities to be an artist. ${ }^{11}$ It can also be seen as a story of a young girl of fin

${ }^{10}$ ['Onnellinen hymy kaunisti hiukan teräviä kasvoja, ja tuo sisällinen valo, joka virtasi hänen silmistänsä ja ikään kuin kehänä ympäröi häntä, muutti hetkittäin hänen jokseenkinjokapäiväiset kasvonsa kauniiksi. Niistä katosi silloin se miltei askeettinen yksinkertaisuus ja ankaruus, joka niille muuten oli niin ominainen. Ja nuorekas melkein lapsellinen ilme sai niissä vallan, ilme, jota ne tuskin ensi nuoruudessakaan olivat tunteneet.'] Translation MLK. Setälä 1907. Helmi Krohn used her married name Setälä until 1913, when she got divorced. All her novels came out under the name Helmi Setälä, except for the first one that was under the pseudonym Anni Kurki.

${ }^{11}$ Lappalainen 1995. 
de siècle debating about family relations, and, particularly, about girls' relationships with her father and mother.

Contrary to Helmi Krohn's novel, the focus in Katinka Rabe is on the child - the subtitle of the book is 'A book of a child'. The mother in the book works as a contrasting image for the growing girl and her identity. The relationship between the mother and the daughter is represented as impossible. This is highlighted in a conflict where the threeyear-old Katinka hits her mother back after being hit by her. ${ }^{12}$

The mother is represented as a lonely figure in the mansion of Hovi with no control over her own life. Katinka's mother does not have any power over the lifestyle of the mansion or its inhabitants, and her own children slip away from her. The difference between mother and daughter is represented in a scene where Katinka sees her mother painfully crying in her room, alone:

Mother twisted her large, freckled hands, and Katinka heard how the joints in her fingers clicked. Katinka's heart divided into two: one part told her to hug her mother, to comfort her, and to say how she loved her mother, that her mother was a thousand times more beloved and better than any other, that she was more beautiful, really, more beautiful than Aunt Agnes Wrensky, than Mrs Adaridi or Mrs Ripas, than anybody, anybody... But the other part in her made her stiffen and speechless; strange suffering made her cold; it was as if she felt ashamed because of her mother. ${ }^{13}$

The possibility for a shared mutual experience turns into a feeling of shame. The mother and her family do not set any examples for Katinka's artistic ambitions - the mother represents a still and modest woman-

${ }^{12}$ Kallas (1920) 1938, 191.

13 ['Äiti väänteli isoja, teerenpilkkuisia käsiään, ja Katinka kuuli, kuinka sorminivelet naksahtivat. Katinkan sydän jakautui kuin kahtia: toinen käski heittäytymään äidin kaulaan, lohduttamaan, että hän Katinka rakastaa äitiä, että äiti on tuhat kertaa rakkaampi ja parempi kuin kaikki muut, kauniimpi, niin juuri, kauniimpikin kuin täti Agnes Wrensky, kuin rouva Adaridi tai rouva Ripas, kuin kaikki, kaikki... Mutta toinen jäykisti sanattomaksi; vieras kärsimys kylmäsi; ikään kuin hävetti äidin takia.'] Translation MLK. Kallas (1920) 1938, 266-267. 
hood that is tied only to motherhood and its conventions and norms. She wanders throughout the book in silence, without a voice of her own. Thus, the mother is represented very differently from the mother of Helmi Krohn's Eva Manner. Possibly it was easier for Helmi Krohn to be empathetic and analytical, since she had a mother of her own that she could idealise. In contrast, Katinka has a close and warm relationship with her father, and the narrator constantly identifies with Katinka and her feelings towards her father. The heritage of the Rabe family is an important part of Katinka's identity, and Katinka is meant to carry on with the Rabe family's tradition through her own, future artistic work.

\section{Mother, in the context of national history}

The youngest daughter, Aune Krohn, became active with her mother's history later on in her life. She was the only one of the sisters who wanted to showcase their mother as a professional, as part of the women's educational history in Finland. She was interested in finding out about the history of their mother, of her personality before her marriage and of the background for her illness. In her short biographical texts on Minna Krohn written in the 1950s, Aune Krohn saw her as one of the silent and forgotten women of the nationalist era, and she wanted to present her mother's life's work to a larger audience:

As a matter of fact, she was talented and had varied skills; she sang, drew beautifully, had a good sense of colour and shape, and wrote. If the times had been different and she would have had Finnish as her mother-tongue, maybe she could have developed her skills further. They were drowned by an incomplete education, home and illness, and perhaps, by her being bilingual. ${ }^{14}$

${ }^{14}$ ['Itse asiassahan hän oli lahjakas ja monipuolinen; lauloi, piirsi kauniisti, omasi hyvän väri- ja muotoaistin, ja kirjoitteli. Jos aika olisi ollut toinen ja hän itse yksinomaisesti suomenkielinen, niin ehkä hänen lahjoistaan olisi voinut kehittyä enemmän. Ne hukkuivat puolinaisiin opintoihin. kotiin ja sairauteen, ja kai myös kaksikielisyyteen.'] Translation MLK. Aune Krohn's letter to Aino Kallas 16 November 1947, SKS. 
Aune Krohn published articles in magazines and, later, in a memoir collection Menneitten aikojen tarinaa [Tales from the past, 1955]. Her interest in the history of her mother was connected to her growing interest in the family history. She was interested in her mother's past both on the individual level and as part of the larger national context. Also, some other biographers noticed Minna Krohn's important role as the longterm teacher and director of the Finnish Girls' School. When Finnish writer and biographer Tyyni Tuulio was, in 1955, writing the biography of Ottilie Stenbäck, the most influential director of this Girls' School in Helsinki, she wrote to Aune Krohn and showed her interest in Minna Krohn's influence as well:

In terms of your mother, her character is alluring and her destiny so peculiar, that I would like to - if I just have time and the energy - to write more about her in some connection. ${ }^{15}$

For the first time, Minna Krohn was shown in her professional role from an outsider's perspective, and Aune Krohn must have been intrigued by this interest. Tuulio's comment did not connect their mother with the melancholic, withdrawn person as seen in the family memorabilia. Tuulio did not write a book on Minna Krohn, but she did ask about the daughter's possible role in writing the history of their mother, and this must have been influential to Aune.

Aune Krohn connected her mother's forgotten past with other forgotten female professionals from the nationalist decades of the nineteenth century. She wrote many other articles on these women, and felt strongly that she had to 'lift these women up' from history and 'defend the defenceless'. ${ }^{16}$ She felt a duty towards her mother's history and her active professional role. For her part, she constructed the national history of the nineteenth century and women's role in it, and was aware of

15 ['Mitä muuten tulee äitiinne, on hänen hahmonsa jotenkin niin puoleensavetävä ja kohtalonsa erikoinen, että joskus mielelläni jossakin yhteydessä - jos elinpäiviä ja työvoimaa riittää - kirjoittaisin hänestä enemmän.'] Aune Krohn tells about this letter in her letter to Aino Kallas 1 November 1950, SKS.

${ }^{16}$ References to Aune Krohn’s texts, see Leskelä-Kärki 2006, 193-194. 
the role of these early women teachers and pedagogues, who had also granted her the possibility to study and be educated.

\section{Minna Krohn in letters and notebooks}

What did Minna Krohn herself write, what kind of material is left from her? Like so many nineteenth-century women and men, she wrote hundreds of letters during her lifetime to her husband, her children, other relatives and close ones. Since the Krohn family archives have been well preserved, many of them are available in the literary archives of the Finnish Literature Society. These letters reveal how Minna Krohn acted in her surroundings and how she took care of family matters.

One interesting source material is her collection of remaining notebooks, to which Aune Krohn refers in a letter to her sister, long after her mother's death:

This diary consists, in part, of something unhealthy, but also healthy and certainly something genuine for mother. So it seems to serve as some sort of a key to her closed inner world as a result of her difficult life and illness. ${ }^{17}$

She refers to the three black notebooks as diaries, although they do not seem to carry the full meaning of diary in the sense of our understanding of a diary; they are not full of inner thoughts and analysis, nor are they even daily descriptions of what has happened. The books seem more to represent the genre of a notebook, although it is important to notice that the genres of both diary and a notebook are never clearly definable. Minna Krohn has written in her books about her notions concerning language and words. She writes in Finnish, Swedish and

${ }^{17}$ Aune Krohn's letter to Aino Kallas 10 October 1948, SKS. ['Osin on siinä päiväkirjassa jollakin lailla sairasta, mutta toisaalta tervettäkin ja varmasti mammalle luonteenomaista, niin että se tavallaan on jonkinlainen avain hänen sulkeutuneeseen sisimpäänsä, elämän järkytyksen ja sairauden sulkemaan.'] Translation MLK. 
German. She writes very short reflections of her children, religion, her health etc. The writings are, however, very sporadic, fragmentary, and the notebooks cover only a few years of her life, from the years 19041906. It seems that they end when her illness becomes more severe, and no later notebooks have been found.

An important view on Minna Krohn's life in the early years of the 1900s can be drawn from Aune Krohn's letters to her sisters. As Aune Krohn lived with her mother and took care of her together with a nurse, she reported on their mother's condition to her sisters, and also reflected on her own situation beside the depressed mother. ${ }^{18}$ We get a layered image of Minna Krohn, a representation of her illness and condition through the eyes of her daughter, from an authentic place and time, but, of course, an already interpreted one. On 6 November 1900, she writes:

Mummy is still tied in bed, but the doctor predicts that the healing process is progressing, step by step. It would be better if mummy, herself, would believe in it, and if her melancholy mind would slightly disappear. If she does not grieve for one thing, she grieves for another, and she can't grab onto moments of joy that still occur for everyone here amidst this despair. Seeing Kaarle [her eldest stepson] is always

${ }^{18}$ In this chapter it is not possible to go further into analysing Krohn's illness further. It is, though, worth mentioning, that at this time, during the early 1900 s, the new psychiatry was a fast developing field, and the diagnoses of mental unstable conditions were changing. The diagnoses of schitzopherenia and psychosis manico-depressiva were starting to be used during the early decades of this century. On the history of mental illness in Finland and the autobiographical narratives related to that, see e.g. Tuohela 2015. Minna Krohn was also taken care of in some mental institutions in Helsinki, such as Tallbacka and Kammio, and an influential psychiatric doctor (first one appointed in Finland) Christian Sibelius diagnosed her disease as well. The daughters talk about illness, and use words such as nerves, melancholia [alakulo], tiredness etc. to describe their mother's condition. One of the aims of my biographical research will be to analyse their interpretations of her illness, and view them as culturally produced. Here, I have chosen to use the more modern concept of depression to describe her condition. 
good for her and occasionally makes her smile. When seeing Helmi, she withdraws into herself and is timid and quiet. ${ }^{19}$

In November 1900, Aune Krohn refers to her mother's health as 'silent', by which she means that her mother is not terribly ill, but the process of getting better is happening very very slowly, 'in millimetres'. One can follow the phases of illness quite closely from Aune Krohn's letters during 1900-1917, but a challenge for the research is that Minna Krohn's own voice, her words and interpretations remain invisible, as is so often the case with patients with mental illness. In her own notebooks, she refers to her illness only on a few occasions and on a very general level. Kirsi Tuohela, who has studied Finnish autobiographies on mental illness, points out how rare these texts are in the early decades of the twentieth century. The first ones written by women are from the 1920 s and 1930 s. $^{20}$

\section{Portraying Minna Krohn}

After reading the daughter's materials on their mother, the portrait painted by Maria Wiik came as a revelation to me. This portrait from 1888 had not been publicly presented, as it was ordered by the Finnish Girls' School and had been hanging on the walls of the school from the 1880 s onwards until it was put in an exhibition at the museum of the University of Helsinki in 2012. Although a biography can never resolve a person's identity or her life-story as a whole, this painting seemed to round out the whole of Minna Krohn's narrative, since it depicts her in

19 ['Mammi on yhä vuoteenomana, mutta tohtori arvelee, että paraneminen käy - askelin eteenpäin. Se kävisi kai vielä paremmin, jos mamma itse siihen uskoisi, ja jos hänen alakuloisuutensa hiukan hälvenisi. Jos ei hän sure toista, niin suree toista, eikä voi tarttua niihin ilon muruihin, joita sentään putoaa muutamia jokaisen osaksi täällä murheen alhossa. Kaarlen näkeminen tekee hänelle aina hyvää, silloin hän toisinaan hymyilee. Helmiä nähdessä sitä vastoin hän kuin vetäytyy kokoon, on arka ja hiljainen.'] Aune Krohn's letter to Aino Kallas 6 November 1900, SKS.

${ }^{20}$ Tuohela 2015. 
the role of a teacher and professional woman, not as a mother or a wife. It inspired me to find new 'odd corners' of her life on which to shed light.

The portrait was painted the same year as Julius Krohn died, after the couple had been married for 12 years. It seems that the portrait was made during the spring, since Julius Krohn died in August and, after that, Minna Krohn was unbalanced for a longer period. The Girls' School must have ordered a painting of their former director, since Minna Krohn did not work at the school any more during the 1880s. At the same time, the school ordered paintings of other former teachers and important persons in the school's history, and Maria Wiik painted some of these as well.

The portrait shows a strong, calm and harmonious Krohn in her professional role as one of the first women school directors. She looks very strong, calm and severe, and like Pia Katerma, who analysed Maria Wiik's production in the 1950s analyses, it is an official picture that has 'inspired its painter to a beautiful, harmonic solution'. Katerma notices how Minna Lindroos' eyes are full of wisdom and she is soulful and balanced. ${ }^{21}$

As a woman painter, Maria Wiik was exceptional, since she was the only woman to paint official portraits during the 1880s. Wiik was among the group of Finnish women artists who became professional painters during the 1870s, studied in Paris at Academié Julian, which also allowed women to educate themselves, and spent several periods in France learning more about their profession. Nowadays, the much more famous and internationally well-known Helene Schjerfbeck was among these women as well, and she was a close friend with Maria Wiik. They shared an atelier in Helsinki, in Paris and in Bretagne, where they lived longer periods. From early on, Wiik was interested in painting portraits, and during the 1880s, she developed this skill by painting, for example, her sister Hilda Wiik, as well as flowers, children, peasantry and sceneries. She received many orders, and in 1888-1889 she devoted all her working hours to painting portraits. In 1888, when Wiik worked on the portrait of Minna Lindroos, she also painted several other portraits,

${ }^{21}$ Katerma 1954, 82. 
mostly of men, such as writer and professor Zacharias Topelius. Minna Lindroos' painting is among the few done of female professionals. Wiik also painted several self-portraits, and was clearly interested in depicting people and studying the human face and character. ${ }^{22}$ Both Wiik and Lindroos could be seen as exceptional women figures in their historical context, since they both chose to carry on a professional life.

This portrait lets us see the teacher and school director Minna Lindroos separate from her roles as mother or wife. Although the painting was painted as an official portrait and it was ordered by the school, one could continue to analyse portrait painting as a biographical process or narrative. Jens Brockmeier has referred to the meaning of portraiture by saying that the art of portraiture has been the art of understanding life since the Renaissance: 'modern portraiture (and self-portraiture in particular) has been, from its beginning, a most sophisticated genre of life-writing.' ${ }^{23}$ This is a fascinating thought when thinking of the process of painting, especially in this case, when one of the first woman portrait painters in Finland paints another pioneering woman. Simultaneously, we must remember that the process of painting is tied to the various conventions and practices of making art, and these conventions are culturally and historically constructed. ${ }^{24}$ British life-writing scholar Maria Tamboukou points out how, 'the painting of a portrait can be seen as a relational narrative par excellence'. She continues referring to Brockmeier:

Pictures and words, imagery and narrativity are interwoven in one and the same semiotic fabric of meaning. They are overlapping trajectories within the same symbolic space, a space of meaning in which our experience takes place and in which we try to make sense of the world. ${ }^{25}$

In her own research, Tamboukou has studied the relationship between American artist Anna Klumpke and French painter Rosa Bonheur, and

\footnotetext{
${ }^{22}$ On Wiik see Katerma 1954 and Konttinen 2000.

${ }^{23}$ Brockmeier 2001, 255 cited in Tamboukou 2010a, 175.

${ }^{24}$ Palin 2004.

${ }^{25}$ Tamboukou 2010a, 175 .
} 
particularly Klumpke's biography on Bonheur. Anna Klumpke had an intensive love relationship with Rosa Bonheur, who wanted Klumpke to both paint her portrait and write her biography. In Klumpke's process of writing about and painting another woman artist, one can interpret her work in the frame of autobiography and biography, as Tamboukou does. ${ }^{26}$ Thus, the situation is very different from the situation where Maria Wiik paints an official portrait on the former girl school director, whom she probably did not even know very well.

However, the painting does seem to offer yet another viewpoint of Minna Krohn and her character. For a researcher who is searching for different representations of Minna Krohn, this portrait does let us see a very different kind of Minna Krohn, quite the opposite of the mentally unbalanced, depressed and lonely figure present in the writings of her daughters. This portrait enables us to see Minna Krohn, or more precisely Minna Lindroos, separate from the roles of mother or wife, as an individual in her own profession. With a sensitive contextualization, Wiik's portrait could be used as one source for constituting the biography of Minna Krohn, and analysed as a biographical process or narrative.

\section{The unresolved Minna Krohn and the possibility of a dialogical biography}

In this book, one of our aims has been to ponder the ethical issues related to biographical research and, particularly, the ethical issue related to the dialogue/relation between the narrator and narratee. For my research, this relationship has been the most intriguing and inspiring one. Doing biographical research is an emotional process. Swedish historian and biographer Eva-Helen Ulvros has said that biography is a genre that demands deep dwelling into other people's lives. It forces us to confront life's big questions: love, sorrow, death, troubles, tragedies. Like Ulvros

${ }^{26}$ Tamboukou 2010a and 2010b. 
has said, it is hard not to be moved by all this. ${ }^{27}$ And here, we always use our own life experience as well, whether we recognise it or not. Swedish historian Boel Englund sees dangers in getting too involved, however, or too close to your subjects. ${ }^{28}$ Danish historian Birgitte Possing, a fellow writer in this book, points out the importance of taking distance when writing biographies, and sees this as a deeply ethical issue. ${ }^{29}$ Although I agree that a biographer needs to take distance, or one could say that writing a biography means balancing between attachment and detachment, I approach this question from a somewhat different perspective. I want to point out the meaning of recognising and reflecting on your emotions during your research process, and of noticing how your relationship towards your subject changes and varies, as well as the writing about these reflections in your biographical research. While the changes are very much related to you as a researcher, they also relate to you as a private person. As in any other research, we always have a reason to write and study something. Like Rachel Morley puts it, writing a biography offers access not only 'into the private sphere of another individual but also into biographer's own mortal, personal being, whether acknowledged or otherwise, real or imagined'. ${ }^{30}$

In the case of Minna Krohn, my involvement with her and her lifestory is manifold. I began by studying her daughters and then became interested in the mother's impact on their lives. I have gradually shifted my gaze towards Minna Krohn herself, and the ways her life could be told. Yet, I am also deeply interested in hearing the voices of others, of those closest to her. After reading her own writings, I also have to

${ }^{27}$ Ulvros 2008, 456-457.

${ }^{28}$ Englund 2008, 228-233.

${ }^{29}$ Possing 2014, 75. See also Englund 2008, 228-233.

${ }^{30}$ Morley 2012, 79. Rachel Morley has inspiringly discussed on the emotional, affective and also bodily processes that happen when writing biographies. I agree with her, that biographers should reflect this issue much more and also write about it in their studies. Morley 2012. See also e.g. Leskelä-Kärki 2006, 78-85, 631-639, and 2014. Erla Hulda Halldórsdóttir comes to a rather similar conclusion, when she claims for the place for historian's emotions saying how the 'the danger of too much distance and coldness towards our subject(s) is that it leaves limited space for emotions (neither ours nor our subject's) or different perspectives.' Halldórsdóttir 2010, 215. 
confess that there seems to be an obstacle, a shadow over her face - as a researcher, I don't feel I can gain access into her thoughts and opinions easily. This is due to her writing style and the ways she presents herself, and also to the limited amount of texts that she has, herself, produced. Her sporadic notions in her notebook are something completely different from, for example, Aino Kallas' lengthy, insightful and deeply selfreflexive diary writings from the early decades of the twentieth century. One must, of course, also consider the problem involved in writing a biography of a woman who spent almost twenty years of her life suffering from mental illness, mostly silent in her bed. All of this will generate huge challenges, also ethical, for this research, but also force me to view Minna Krohn through the representations brought forth by others.

Looking at the different kinds of images these various sources provide on Minna Krohn or Maria Lindroos, one must admit that it is not possible to write one, coherent life-story of Minna Krohn. Rather, these different images create a prism that illuminates her character and challenge us to create a new biography that emphasises differences and endeavours to describe lives from the perspective of contradictions. It is, thus, related to the notion of an identity that is vague and changing.

The case of Minna Krohn lets us see behind the history of the famous, of the canonised, and look for the histories of the forgotten, diminished or silenced ones. ${ }^{31}$ Minna Krohn is particularly interesting because of her conflicting identities and roles; she directed a girls' school for seven years and was among the first educated women in Finland, but is yet seen, particularly in Aino Kallas' eyes, as quite a failed figure. Opening up the different textual and visual representations of her alongside her own material, as well as letting the contradictions stay visible in the final result might be a way to make room for the unresolved figure of Minna Krohn.

${ }^{31}$ Compare to the chapter in this book discussing the life of Sigríður Pálsdóttir by Erla Hulda Halldórsdottir. 


\section{Bibliography}

\section{Archival sources}

Literary Archives of Finnish Literature Society (SKS), Helsinki

Aune Krohn's letters to Aino Kallas

Minna Krohn's archive, personal notebooks

\section{Other primary source material}

Kallas, Aino: Katinka Rabe. Kirja lapsesta. Original 1920. Kallas, Aino: Valitut teokset II. Meren takaa. Otava, Helsinki 1938.

Krohn, Aune: Menneitten aikojen tarinaa. Valistus, Helsinki 1955.

Setälä, Helmi: Vanhan kartanon tarina. Otava, Helsinki 1907.

\section{Literature}

Brockmeier, Jens: Narrative and Identity: Studies in Autobiography, Self and Culture. Ed. with Donald Carbaugh. John Benjamins, Amsterdam, Philadelphia 2001.

Cavarero, Adriana: Relating narratives. Storytelling and selfhood. First published in Italian 1997 Tu che mi guardi, tu che mi racconti. Transl. by Paul A. Kottman. Routledge, London, New York 2000.

Dever, Maryanne; Vickery, Ann and Newman, Sally: The Intimate Archive: Journeys Through Private Papers. National Library of Australia, Canberra 2009.

Eakin, John Paul: How our lives become stories: Making Lives. Cornell University Press, Ithaca, New York 1999.

Englund, Boel: Att förstå ett liv som levdes för längesedan - reflektioner över biografin som historisk metod. Rätten till ordet. En kollektivbiografi över skrivande Stockholmskvinnor 1880-1920. Eds. Boel Englund, and Lena Kåreland. Carlsson bokförlag, Stockholm 2008, $228-233$.

Halldórsdóttir, Erla Hulda: Baldvin's Tear. The Materiality of the Past. Making Sense, Crafting History: Practices of Producing Historical Meaning. Eds. Izabella Agárdi, Berteke Waaldijk, and Carla Salvaterra. Plus-Pisa University Press, Pisa 2010, 207-219.

Jansdotter, Anna: Seeking a usable methodology: The production of the fin-de-siècle female prostitute. Qualitative Research. 8 (2008), 307-317.

Katerma Pia: Maria Wiik. WSOY, Porvoo, Helsinki 1954.

Konttinen, Riitta: Maria Wiik. Otava, Helsinki 2000.

Kurvet-Käosaar, Leena: Theoretical reflections on Gender, Life-Writing and Relationality. Speech at a conference Revisiting relationality, gender and life-writing. Estonian Literary Museum, 1-2 November, Tartu 2012.

Lappalainen, Päivi: Tuoksuvat kukat ja kultaiset hedelmät. Aino Kallaksen Katinka Rabe identiteetin rakentumisen kuvauksena. Identiteettiongelmia suomalaisessa kirjallisuudessa. Ed. Kaisa Kurikka. Taiteiden tutkimuksen laitos, Turun yliopisto 1995, 168-188.

Lassila, Pertti: Ihanteiden isänmaa. Julius Krohnin romanttinen fennomania ja kirjallisuus. SKS, Helsinki 2003.

Larsson, Lisbeth: Sanning och konsekvens. Marika Stiernstedt, Ludvig Nordström och de biografiska berättelserna. Nordstedts, Stockholm 2001. 
Lieblich, Amia: Writing Biography as a Relationship. Nashim: A Journal of Jewish Women's Studies \& Gender Issues. 7, Spring 5764 (2004), 206-211.

Liljeström, Marianne: Identiteettihalu: venäläisten naisten omaelämäkerrallinen tekijyys. Ritvan ystäväkirja. Eds. Maarit Leskelä-Kärki, Kirsi Tuohela and Kaisa Vehkalahti. k\&hkustannus, Turku 2013, 329-338.

Leskelä-Kärki, Maarit: Suhteellista elämää. Relationaalisuus ja biografinen vuorovaikutus. Historiallinen elämä - biografia ja historiantutkimus. Eds. Heini Hakosalo, Seija Jalagin, Marianne Junila and Heidi Kurvinen. SKS, Helsinki 2014, 314-331.

Leskelä-Kärki, Maarit: Kirjoittaen maailmassa. Krohnin sisaretja kirjallinen elämä. SKS, Helsinki 2006.

Leskelä-Kärki, Maarit: Narrating life-stories in-between the fictional and the autobiographical. Qualitative Research. 8 (2008), 325-332.

Morley, Rachel: Fighting feeling: Re-thinking biographical praxis. Life Writing. 9:1 (2012), 77-95.

Palin, Tutta: Oireileva miljöömuotokuva. Yksityiskohdat sukupuoli- ja säätyhierarkian haastajina. Taide, Helsinki 2004.

Possing, Birgitte: Elämä pelissä. Biografian historia ja vastuu. Historiallinen elämä - biografia ja historiantutkimus. Eds. Heini Hakosalo, Seija Jalagin, Marianne Junila and Heidi Kurvinen. SKS, Helsinki 2014, 62-78.

Smith, Sidonie and Watson, Julia: Introduction: Situating Subjectivity in in Women's Autobiographical Practices. Women, Autobiography, Theory. A Reader. Eds. Sidonie Smith and Julia Watson. The University of Wisconsin Press, Wisconsin 1998, 3-51.

Smith, Sidonie and Watson, Julia: Reading Autobiography: Interpreting Life Narratives (2nd Edition). University of Minnesota Press, Minneapolis 2010.

Tamboukou, Maria: Relational narratives: Auto/biography and the portrait. Women's Studies International Forum. 33 (2010), 170-179. (2010a)

Tamboukou, Maria: In the Fold between Power and Desire. Women Artists' Narratives. Cambridge Scholar's Publishing, Cambridge 2010 (2010b).

Tuohela, Kirsi: Sielun ja mielen sairaus. Varhaiset psyykkisen sairastamisen omaelämäkerrat Suomessa. Kipupisteissä. Sairaus, kulttuuri ja modernisoituva Suomi. Eds. Jutta Ahlbeck, Päivi Lappalainen, Kati Launis, Kirsi Tuohela and Jasmine Westerlund. Utu-kirjat, Turku 2015, 195-232.

Woolf, Virginia: The art of biography. The death of the moth and other essays, 1942. Web edition of eBooks@Adelaide.

https://ebooks.adelaide.edu.au/w/woolf/virginia/w91d/index.htm

Ulvros, Eva-Helen: När källkritiken möter gestaltningens utmaningar. Att skriva biografier. Historisk Tidskrift för Finland. 4 (2009), 441-457. 


\title{
Coming together: \\ Early Finnish medical women and the multiple levels of historical biography ${ }^{1}$
}

\author{
Heini Hakosalo
}

Biographical research has often been characterised as a privileged means of analysing the interplay between individual choices on the one hand and non-individual "structures" on the other hand. ${ }^{2}$ I will start by describing how I see this interaction and then move on to the main theme of my chapter, i.e. to distinguishing between three levels of biography and discussing the specific contribution of each of them to the biographical enterprise. These levels are set biography (prosopography), group biography and individual biography. I will also say a few words about collective biography, which is often - and in my view confusingly

${ }^{1}$ An earlier version of this article was published in Finnish as 'Tasohyppelyä. Varhaiset suomalaiset lääkärinaiset ja biografisen tutkimuksen monimuotoisuus' (Hakosalo 2014a).

2 Scholars have conceptualised this key question using different terms. Daniel Bertaux speaks about 'the relationship between individual and collective praxis and socio-historical change', Bertaux 1981, 6; Jane Martin talks about the points of intersection between agency and social structures, Martin 2003, 219-232; while Lorraine Daston and Otto Sibum are interested in the way that the 'scientific persona' is formed at the intersection of 'cultural categories' and 'individual life courses', Daston and Sibum 2003, 2-3. See also Nasaw 2009, 576. 
- equated with set and / or group biography. As soon as researchers leave the relatively safe ground of individual biography, or biography proper, definitions tend to become unstable. However, it seems to me both possible and useful to distinguish between these forms of biography heuristically. Of course, it is no less possible to practice them side by side, even within a single study.

The examples that I refer to in this chapter are mostly drawn from the history of science. ${ }^{3}$ This solution is motivated by my own background in this field, but also by the fact that scientific biography does not otherwise get much exposure in this volume. In exemplifying concrete methodological steps and choices, I refer to a research project of mine that dealt with early Finnish (and Swedish) female physicians, who trained during the last decades of the nineteenth and first decades of the twentieth century. ${ }^{4}$ Only a small minority of them engaged in research, and the study was therefore a professional, at least as much as a scientific, biography. The key concepts of the study were medical knowledge, professional and scientific power and gender. In the course of the project, I found - partly to my own surprise - that the biographical approach was a highly useful way of tackling these issues.

\section{Horizon of possibilities}

In conceptualising the interaction between an actor and historical circumstances, between individuals and structures, I relied on the notion

${ }^{3}$ On the use of biographical methods in history of science, see, e.g. Söderqvist 2007; Shortland and Yeo 1996; Kragh 1991, 174-196. Some science history journals have published theme issues on biography (e.g. Science in Context $16 / 2003,1-2$ ). Judging by the number of calls for papers to science history conferences or conference sessions that focus on biographical research, we are likely to have some more edited volumes on the topic in the near future.

${ }^{4}$ The overall project was called Exclusive Treatment: The First Generations of Finnish Medical Women, and the results have so far been discussed in, e.g., Hakosalo 2012a, 2012b, 2014a, 2014b, 2014c, 2015a, 2015b, 2015c and 2015 d. 
of "horizon of possibilities"s. The notion refers to the range of possibilities that an actor has, de jure and de facto, at a specific point in time. A horizon of possibilities is a highly historical phenomenon, susceptible to constant change. It is changeable in at least three respects. First, what is and what is not possible for an individual differs from one historical context to another. Jane Austen could not buy a car, but she could take a diligence from Bath to London. I can do the former but not the latter. Such restrictions and possibilities, the kind that affect everyone living in a certain culture at a given time, are often so obvious that they are not articulated in biographical research. Secondly, different (groups of) people living in the same historical context face different horizons of possibilities. The range and outlook of the horizon depends, for instance, on age, social group, gender and language. Jane Austen could not inherit her father's landed property, but her brother could. Third, an individual's horizon of possibilities changes in the course of her lifetime, as she moves from one phase and age-specific set of circumstances to another. A child's potential sphere of action differs from that of an adult, and the options available to a middle-aged person differ from those available to an octogenarian. In modern societies, formal degree education has been one way in which people have consciously tried to expand their horizon of possibilities. This is also what the women in my research set did.

An individual is typically aware of only part of the possibilities open to her, and will try to realise an even smaller part. Jane Austen did not make use of the possibility of marriage, but she did realise the much less obvious possibility of writing and publishing novels. Biographers have, understandably, been particularly interested in people like her, i.e. in people who make choices that are atypical of their time, social group and / or sex, and, by so doing, sometimes also expand the horizon of possibilities of those coming after them.

The concept of horizon of possibility had the added benefit of being compatible with the basic definition of power that I relied on. According to this definition, we can speak about a power relationship between indi-

5 The term is used in literary studies, but in a different meaning, viz. to describe all the interpretative possibilities involved in the reception of a literary product. 
viduals (or groups) $a$ and $b$, if 'the actions of $a$ reorder the set of possible actions of $b^{\prime}$. Thus, a person who significantly and effectively shapes another persons's horizon of possibilies also exerts power over her. In addition to individuals intentionally shaping each other's range of possible actions, I also found it necessary to take into account mechanisms of power, that is, the kind of relatively stable practices that clearly had the potential to 'reorder the set of possible actions' of the women of my set but that could not be traced back to any specific individual(s). Professional and particularly the academic culture were and are replete with such mechanisms.

Biographical research does not only ask 'what' but also 'why'. Studying lives, you do not only chart actual and realised possibilities; you also want to know why some possibilities were realised in the lives of some people and other possibilities were left unrealised. The three levels of biographical study shed light on this basic issue from slightly different, complementary points of view.

\section{'A collection of elements' - on set biographical research}

I will talk about "set biography" rather than, and instead of, "prosopography" . Not only is the former less painful to pronounce but it is also well-suited for the purpose as far as content goes: the mathematical definition of a set can be used as the starting point of set biography. According to Georg Cantor's classic definition, 'a set is a collection of elements', or distinguishable objects. As we may (or may not) remember from school mathematics, the objects in a set are called members or elements. The members of the set should be distinct and well-defined. A set can be described either by listing each element or by naming the properties that the elements share.

6 Kusch 1991, 122.

7 On various definitions of prosopography, see Keats-Rohan 2004; Uotinen 2014, 243-244. On prosopography in the history of science, see Kragh $1987,174-181$. 
Similarly, the set biographical exercise begins with the description of the research set. In set biography, the 'elements' are human beings. The researcher defines one or more properties that function as the selective principles. For instance, the members of my index set shared two basic properties: they were women and they registered at the Medical Faculty of the Imperial Alexander's University (later the University of Helsinki) between the beginning of 1888 and the end of 1917.

Sometimes the description of a biographical set is in itself a major undertaking. With sporadic source material and other complications, it can be a challenge to ascertain which historical actors genuinely belong to the set, and to make sure that they do not appear there more than once. My research set was finite, relatively small and relatively easy to describe, thanks to the meticulous Finnish university bureaucrats and the cultural convention according to which it was rude to refer to women by surname only. The process of identification did present some minor complications, however. For instance, women's surnames changed fairly often. Changes were occasioned by marriages and by the replacement of Swedish surnames with Finnish ones, which was common in early twentieth-century Finland. The identification of the elements of the set was facilitated by the fact that both Finnish and Swedish first names are usually clearly gendered. However, I would not have assumed the student named 'Venus' was a man, had his second name not been 'Ludvig'.

The second quality that characterised the members of my index set was that they enrolled at the Medical Faculty of Alexander's University between 1888, which is when the first regular female students were registered, and the end of 1917, when Finland became independent. The set thus described had 85 members. Since the Medical Faculty was the only medical school in Finland until 1943, the set included all women who studied medicine during this period, including those who did not graduate. Even in Sweden, where there were three medical schools, it would have been much more difficult to identify all female medical students, the drop-outs included. In the case of Great Britain or the United States, the enumeration of the members of the set would probably have been impossible, at least for a single researcher. 70 of the 85 women in my index set graduated as licentiates of medicine (the basic medical degree in Finland), the last ones in 1929. During the same period, 976 
men began medical studies. They constituted one reference group in my study. Another reference group was formed by the 175 women who registered as medical students at the Karolinska Institutet in Stockholm, Sweden, between 1888 and 1917.

With the limits of the set thus drawn, I could move to the second phase of set biography and pose a series of questions to its members with the purpose of collecting data that was large and uniform enough to allow trends and patterns to be distinguished. I was interested, among other things, in the cultural, social and economic capital that the members of the set had on entering the university (as indicated by father's occupation and social status, language, place of residence and school); their study paths (as marked by the length of their studies, their internships at various clinics, and special research assignments); their position(s) within the medical field after graduation (as indicated by specialty, sector, place of residence, place in professional hierarchy, length of career); their contribution to medical discourse (as indicated by the number of their scientific and popular publications); and their share in professional and scientific power (as indicated by various gatekeeper positions at the university, in state medical administration and in medical journals and societies). I was also interested in their extra-professional life choices and preferences: family, religion, and major nonprofessional preoccupations. Information about these matters could be found in the university and faculty student rolls, in the professional register and in the medical register of the National Board of Health. Complementary sources of information included the proceedings of the council of the Medical Faculty as well as documents produced by various hospitals, the Medical Association and the two national medical societies. The data should be as uniform and comprehensive as possible: questions that cannot be answered for all members of the set fall, strictly speaking, outside the set biographical exercise.

Where does the value of set biographical study lie from the point of view of biographical research in general? What does it bring to light that would otherwise be likely to remain unseen? First, merely pointing out the existence of a set can sometimes have scholarly and / or political significance. By describing a set a study can make visible a group of people that has, for one reason or another, not been seen before. To 


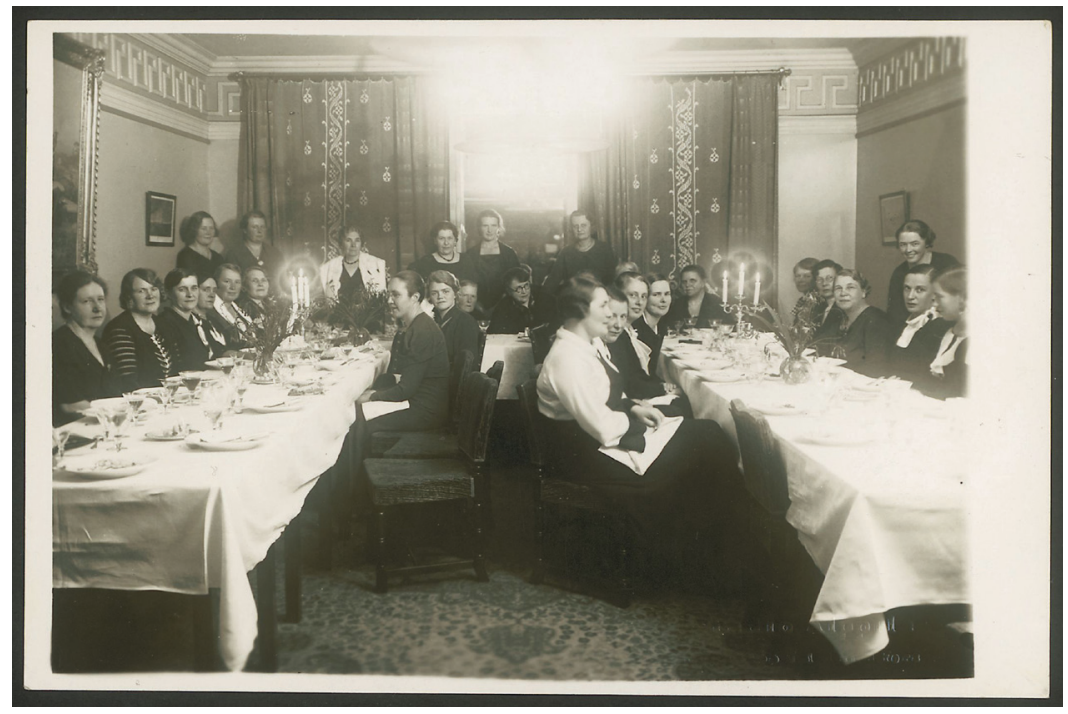

Figure 1. Women physicians' annual dinner in Helsinki in 1934. Women physicians, wary of all forms of professional segregationism, kept their meetings on informal basis until 1947, when the Society of Finnish Women Physicians was founded. (The Archive of the Society of Finnish Medical Women. Finnish National Archive, Helsinki.)

some extent, this is true also for my set. To be sure, there are some wellknown individuals in the set, but early medical women had seldom if ever been seen as a group. In Finland, women's medical studies were not discussed, let alone debated, in the newspapers, within the Medical Faculty or the Academic Senate, or in medical journals ${ }^{8}$. Neither do women physicians emerge as a distinct group in the historical accounts of medical societies or in the memoirs of male physicians. This 'invisibility' partly resulted from a conscious strategy adopted by the women physicians. They strove towards seamless professional integration and were horrified by countries (such as Russia) where 'lady physicians' were a distinct professional category. They sought to advance this strategic goal by carefully avoiding anything that might set them apart. (Figure

8 The Medical Society (Finska Läkaresällskapet) did discuss women's medical education once (1873) and the regulations concerning women's medical work also once (1899). Förhandlingar 1875; Förhandlingar 1900. 
1) In fact, you can still meet people in Finland who think that it is morally and politically questionable to draw attention to a quality as irrelevant, from the point of view of professional competence, as gender by coupling the word 'female' with the word 'physician'.

Secondly, the size of a set can sometimes be an interesting result. Elina Sana made headlines in 2003 by disclosing the number of Jews and prisoners of war that Finland turned over to Nazi Germany during the Second World War.' The project 'Finnish war mortalities 1914-22' (Suomen sotasurmat 1914-22) changed our view about this historical period, although the database that was the main outcome of the project contains nothing more than the number of people killed during this period, their names and their causes of death. ${ }^{10}$ Counting early female physicians did not present any major surprises, but it did show that the proportion of women in the Finnish medical profession was relatively high already by the third decade of the twentieth century ( 8.9 per cent of doctors licenced in 1896-1929 were female) and the proportion of women dentists was internationally speaking very high. According to the dentists' register of 1928, women constituted 58 per cent of all dentists active in the country ${ }^{11}$, which might well be a world record. This fact, in turn, called into question the universality of the correlation that is often postulated between the "feminisation" of a profession on the one hand and the decrease in its income and social status on the other hand. Despite early "feminisation", both the medical and the dental professions have enjoyed and continue to enjoy both high income and high social status.

Third, the set biographical approach sheds light on various life and career patterns, showing which patterns were common and typical and which were, in turn, uncommon and atypical. I found that the study paths of men and women in the index and references sets, respectively, differed only slightly, while the career patterns of the two sets differed significantly. During the first half of the twentieth century, the typical 'male career' clearly differed from the typical 'female career'. Women

\footnotetext{
9 Sana 2003.

${ }^{10}$ http://vesta.narc.fi/cgi-bin/db2www/sotasurmaetusivu/main

11 Lund 1928.
} 


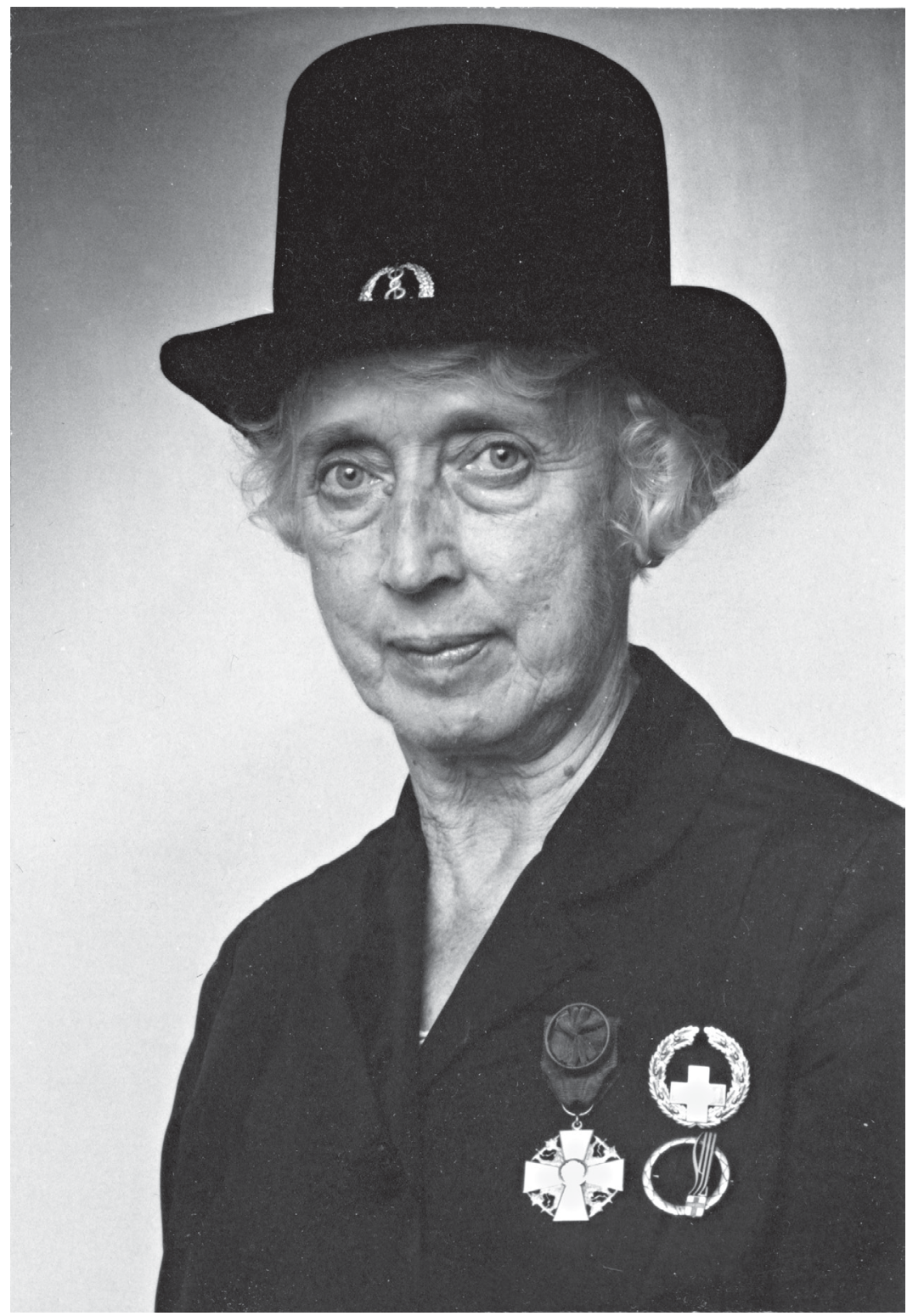

Figure 2. Göta Tingvald-Hannikainen (1896-1982), MD, wearing her "doctor's hat", i.e. the hat that those awarded the doctoral degree are entitled to wear in solemn academic occasions. Ten women of the set earned a doctorate, a necessary but not a sufficient condition for academic advancement. (Helsinki University Museum.) 
physicians were overrepresented in private practice and in two rapidly growing low-status specialties, tuberculosis medicine and psychiatry. ${ }^{12}$ In Finland, almost all male doctors held at least one office. Public posts came with a steady salary and high social status. The highest status was attached to state posts. Women were excluded from the majority of these posts until 1926. Very few women were able to climb up the state medical hierarchy, including the university (Figure 2). Several women worked at the university hospital at the early stages of their career, but almost all of them left this path after 2 to 5 years, around the time it would have been time for them to start competing for permanent posts. Women's career paths also steered well clear of the main centres of professional and scientific power, namely, the National Board of Health, the boards of the national medical societies and the editorships of their journals, the leadership of the Medical Association and the Medical Faculty. ${ }^{13}$

Pioneer prosopographers in the history of science were particularly interested in charting possible correlations between peaks of scientific productivity on the one hand and various social and ideological trends on the other hand. For instance, Robert Merton found a strong correlation between scientific productivity, religious puritanism and rise of the bourgeoisie in seventeenth-century England in his seminal Science, Technology and Society in Seventeenth Century England (1938) ${ }^{14}$. Other historians (and sociologists) of science have also employed set biography to explore the relationship between 'Protestant ethics and the spirit of capitalism'. Steven Shapin and Arnold Thackray showed that the thriving scientific culture of eighteenth century Britain required not only a small group of creative scientists but also a much larger 'audience' consisting of people who actively followed scientific research and supported it. Shapin and Thackray regarded set biography as a means to show how

${ }^{12}$ Early medical women were well represented in tuberculosis medicine and psychiatry in Britain, too. Elston 1986.

${ }^{13}$ The only exception is Laimi Leidenius (1877-1938), who was professor of obstetrics and gynaecology in 1930-38.

${ }^{14}$ Merton 1938, 360-632. 
closely science was connected to the rest of society, and 'a sophisticated tool for establishing links between action and context'. ${ }^{15}$

I asked whether women physicians' scientific output correlated with their academic success. Did they get their due? Or did the set include individuals like the anthropologist Hilma Granqvist (1890-1972), whose extensive, internationally acknowledged scientific production the university of Helsinki was not prepared to reward even with an adjunct professorship ${ }^{16}$, let alone a professorship proper? There were no 'granqvists' in my set, i.e. women whose academic advancement was starkly disproportionate to the quality and quantity of their productivity. However, one cannot conclude from this that the Medical Faculty was an islet of gender equality. In medicine, it was simply not possible to carry out major research projects - either clinical or scientific - without access to clinical or other resources, which in turn only came with an academic position. Therefore, an outstanding medical researcher unaffiliated with the university or other large hospital was by definition an impossibility.

By looking at the studies and careers of all physicians I could see the horizon of professional possibilities at its greatest extent. By looking at the much smaller group of women students and physicians I learned something about the ways in which gender affected the horizon of possibilities of female and male medical professionals at different stages of their studies and careers. However, there are many questions that set biographical approach could not answer: it could not tell me whether the gendered differences were here because women were not given the same opportunities as men, or because they chose differently than men. Neither could it explain why women were deprived of certain possibili-

${ }^{15}$ Shapin and Thackray 1974, 3. See also Jones 2001, 325-346. In the history of medicine, set biographical approach has been applied by e.g. Crowther and Dupree 2007.

${ }^{16}$ Finnish dosentti is equivalent to Swedish docent and German Privatdozent but lacks a direct equivalent in the Anglo-American academic system. It is usually rendered in English as adjunct professor. A docentship is neither a degree nor a salaried post, but an honorary title that indicates that you have been evaluated and found qualified for teaching at the university level. In the normal course of things, adjunct professorship, in the Finnish context, was the intermediary stage between a doctorate and a chair. 
ties or why they chose differently than men. But by bringing into light the major differences between the study and career patterns of men and women, the set biography indicated where I might usefully start looking for answers to these questions. In order to find answers, I needed to turn my attention from the set to groups and individuals.

\section{No man is an island - the contribution of group biography to biographical research}

I prefer to distinguish group biography both from set biography and from collective biography. Not all authors agree with me in this respect. The term prosopography is often used interchangeably with "collective biography"17, and some authors equate both with group biography ${ }^{18}$. Barbara Caine does not regard prosopography as a form of biography at all, while she is very keen on group biography, which she defines as a subspecies of collective biography ${ }^{19}$. As I see it, group biography is the kind of biography that focuses on a restricted, usually smallish group of people, who formed a group already in their own and / or their contemporaries' eyes. A group is not primarily defined by a small number of shared qualities, like a set, but rather on the basis of the relations between its members. A group is formed by people who were related to each other and who influenced each other's choices and, in the case of long-standing groups and relations, also each other's personalities. Indeed, a group biographer is particularly interested in these relationships and influences. A pair biography of two individuals who interacted with each other and influenced each other's choices (i.e. reordered each other's "horizon of possibilities") would then be a subclass of group biography. Such pairs typically include spouses and siblings, as well as parent-child and teacher-student pairs. An example from my own study are Elin and Robert Elmgren, sister and brother, who graduated as licen-

\footnotetext{
${ }^{17}$ E.g. Bruneau 1994, 65, 67.

${ }^{18}$ Jones 2001, 325, 329.

${ }^{19}$ Caine 2010, 48, 57.
} 
tiates of medicine within a few months in 1899-1900. By investigating their lives side by side, I was able to analyse the impact of gender in the making of a medical career in early 20th-century Finland ${ }^{20}$.

With "collective biography" I refer to the kind of research that deals with parallel lives that do not (necessarily) intersect. The targets of a collective biography need not have had any mutual relationship at all. If there were some connections, the biographer is not primarily concerned with them. A biographical study on, say, the Westermarck school would be likely to be a group biography, while Suomen professorit 1640-2007 [Finnish professors 1640-2007] is a typical collective biography. A group biography is like a group portrait: a single, integrated work of art, where the way each individual is portrayed influences both the overall composition and the way that the other members of the group are depicted. A collective biography is, rather, like a room - or perhaps a long gallery - whose walls are adorned by separate portraits of individuals (cf. national biographies). Each portrait stays within its own frame and may well differ from its neighbours in age and style. Typically, however, the subjects are portrayed rather stereotypically, from the same angle, with the better side showing. A parallel biography of two people who did not exert any significant influence on each other would then be a subclass of collective biography.

Beginning from the 1980s, many - perhaps most - group biographies have been written by women on women. The protagonists have been linked sometimes by blood, sometimes by other things, such as a shared political goal. ${ }^{21}$ (An interesting question that cannot be tackled here is why the role of groups and networks tend to get emphasised in the case of women.) In the history of science, group biographies have been written on research schools and groups, on couples and networks. ${ }^{22}$ I do not know of genuine group biographies of women scientists, perhaps because all-female research groups have been exceedingly rare, but there are plenty of collective biographies on women scientists. My own

${ }^{20}$ Hakosalo 2015b.

21 Sibling biographies have been written by, among others, Caine 1986; Leskelä-Kärki 2006. Florin 2006 and Bosch and Kloosterman 1990 have focused on women's suffrage activists' groups and networks.

22 Pair biographies include e.g. Pycior et al. 1995 and Berg et al. 2011. 
research on early medical women included elements of group biography: I distinguished within my larger set some smaller groups, whose interaction was particularly intensive and long-lasting. Their letters - typical source material for group biographies - allowed me to look deep into their relationships and forms of interaction.

What is the signature contribution of group biography to biographical research at large? First, group biography can be useful in exploring the historicity and changeability of various forms of human relationships. For instance, the nature of the marital relationship has changed over time, as have sibling and parental relationships. Biographies of groups of professionals can shed light on changing collegial relationships. Group biography provides a way to look into these relationships in action, in different historical contexts. Secondly, group biography can tell us how and why groups were formed, what kept them together and what caused them to dissolve. Why, for instance, did a research group or school emerge where and when it did and take its specific form? What tied the members of a political clique together? What eventually broke it down? Power and emotions - and, in the case of scientific biography, knowledge - are often central themes in group biography.

My own material showed, for instance, the impact of generational change on group dynamics. The smaller and the more distinct minority the women were at the university, the better gender sufficed in bringing and keeping them together. The more numerous the women students, the more heavily their group formation depended on other things too. During the first generation of women students (those who started at the university in 1885-95), gender was enough to bond women together. They formed a semi-official grouping that proved highly significant for many of its members both during their studies and afterwards. This group was first known simply as 'de kvinnliga' (the female students), and then, when a new and in some respects different student generation had entered the university, as 'de gamla kvinnliga' (the old female students). The group included women from different faculties, from both language groups (although the language they used among themselves was self-evidently Swedish at this point), from different social classes and from different parts of the country. The inofficial but unquestio- 


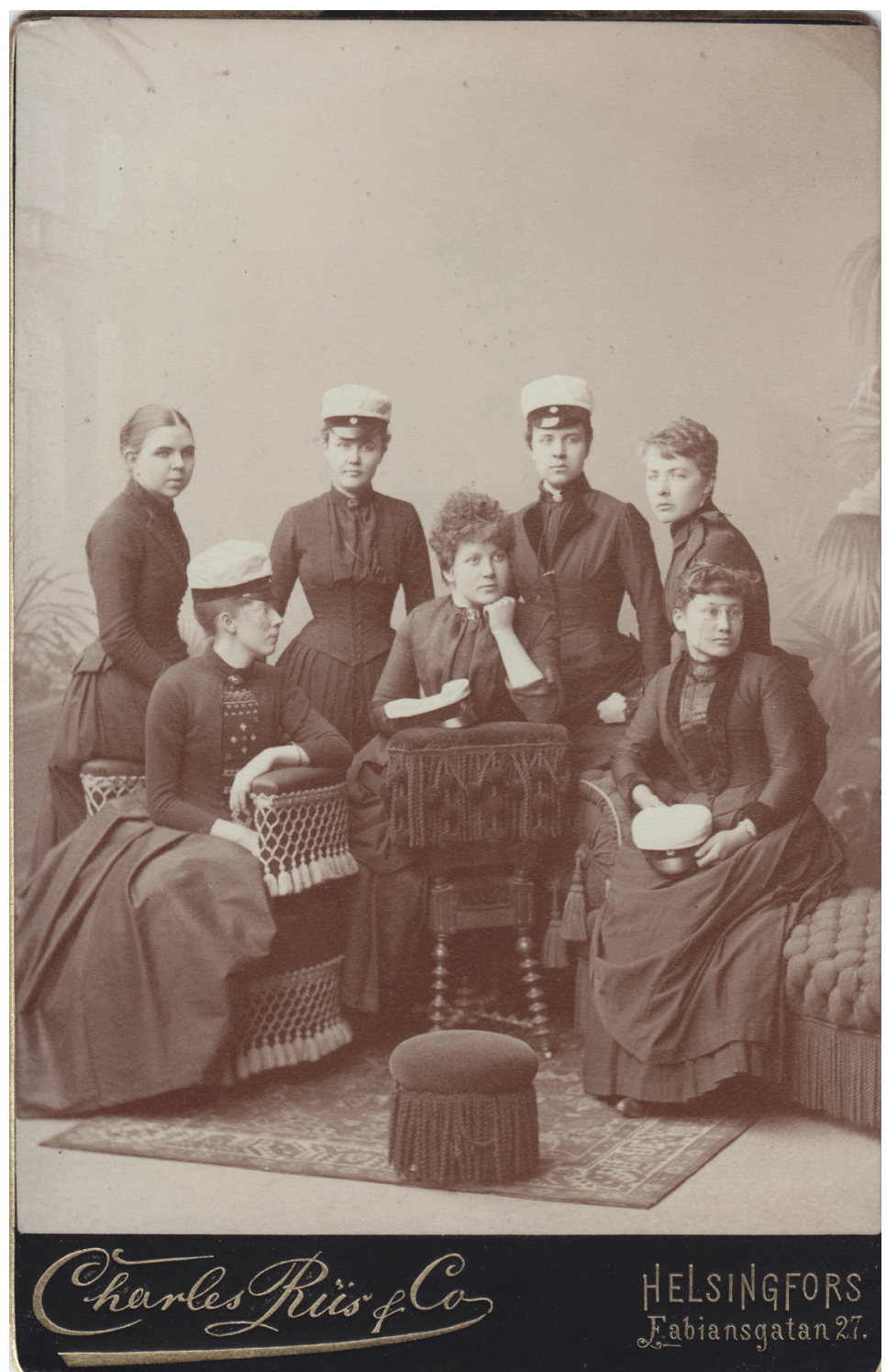

Figure 3. The core group of 'de kvinnliga' during the academic year 18871888. Karolina Eskelin is standing in the back, second from the right. (Helsinki University Museum.) 
ned leader of the group was a medical student, Karolina Eskelin (18671936). (Figure 3)

The second generation consisted of the women who matriculated at the university between 1895 and 1905 . The number of female students was on the rise, and medical students now tended to seek and find their friends within the medical faculty. One such group of life-long friends was formed by Viva Lagerborg (1871-1941), Anna Wikander (1873-1938) and Eva Piispanen (1877-1950). They were all women, and majored in medicine, but differed from each other with regard to social, linguistic and regional background. (Figure 4) The group formation of the third generation of female medical students (matriculated 1905-1915) was more socially selective. Friendships tended to develop between women who shared similar social and ideological backgrounds. For instance, Selma Rainio (1873-1939), Laimi Leidenius (1877-1938) and Helmi Heikinheimo (1879-1968) had all grown up in rural parsonages in inner Finland, surrounded by a host of siblings. They were all deeply religious and held similar political views.

What held a group together, sometimes for decades? Sometimes the bond was constituted by shared interests and goals. The Swedish suffragists that Christina Florin studied in her book Kvinnor fär röst (2006) initially shared a political goal, but, as the struggle for the vote dragged on, they came to share many other things as well. In my case study, the letters of medical women contained a lot of references to the things that contributed to the stability of their groups and networks: They exchanged information (on all matters medical, as well as on patients and nurses) and drug prescriptions; lent money to and borrowed money from each other; guaranteed each other's loans; treated each other and each other's family members, usually for free; travelled together on business and for pleasure. However, group cohesion did not spring only from carefully balanced gift exchange ${ }^{23}$ or shared interests but also from strong emotional experiences that often dated back to their student and sometimes even to school years.

${ }^{23}$ On the concept of gift exchange in the study of scientific networks, see Vilén 2013. 


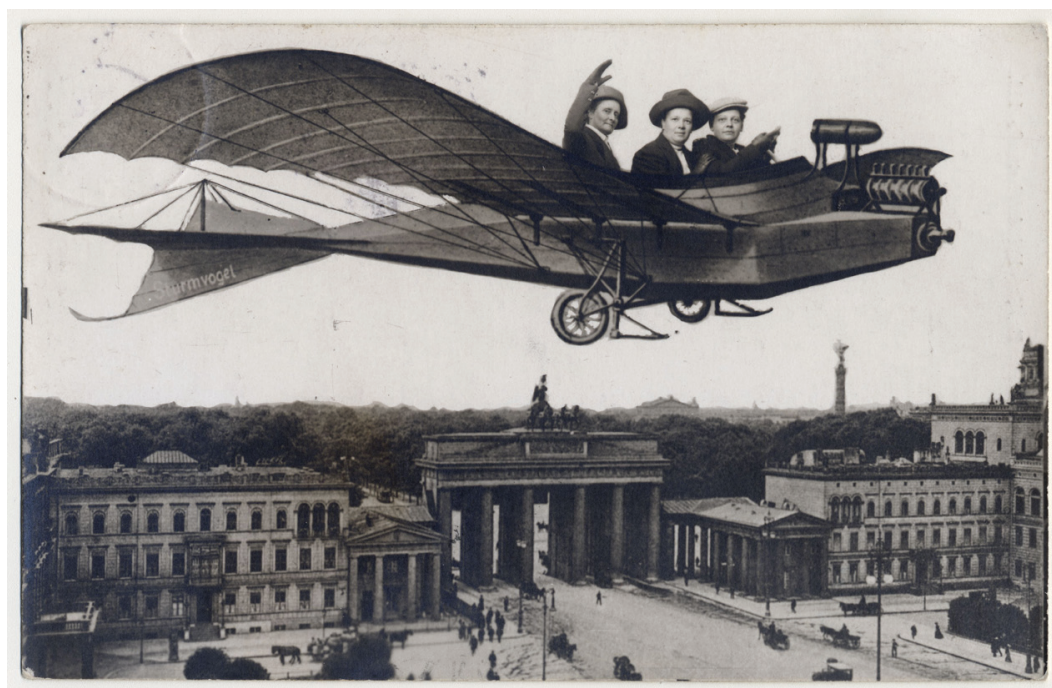

Figure 4. Viva Lagerborg, Eva Piispanen and Anna Wikander often travelled together, both for business and for pleasure. In 1913, they had their picture taken in Berlin. (Rolf Lagerborg's Archive. The Manuscript Collection of the Åbo Akademi University Library, Turku.)

Being a member of a group can have an immediate and profound impact on an individual's horizon of possibilities. A membership can, by itself, open up some possibilities and close others. But it can also exert indirect influence: being a member of a group can explain why a person pursues one possibility and rejects another one. Family often exerts crucial influence on an individual's career choices, especially so in the case of women. During the first half of the century, having children almost invariably made a woman physician give up full-time work and move either to part-time practice or to a part-time office, for instance to the office of school physician. However, female physicians, unlike teachers and nurses, seldom gave up work altogether when they married and had children. Not only family members but also friends and colleagues often influenced an individual's career choices. For instance, it was hardly a coincidence that all members of 'the Lagerborg group' opted for tuberculosis medicine. 
Being part of a group can explain ruptures and unexpected turns in a career path but also account for continuity and perseverance. In the case of early medical women, friends and colleagues were crucial in compensating for the lack of systematic refresher education, supervision and mentoring, which was one of the major problems facing an early 20th-century Finnish physician. Members of a group helped each other to keep up with new medical developments. They provided information on new forms of treatment, offered consultation and shared material resources, e.g. instruments. They also offered each other advice and psychological support, akin to present-day work supervision, thereby alleviating the loneliness and psychological strain that was part of medical work.

One question that often comes up in scientific and professional biographies is the significance of group membership for scientific and professional success. Study of scientific schools and research teams is interesting largely because scientists have, as a group, achieved something that none of them could have achieved alone. In my case study, the impact of women's own groups and networks on professional success was weak and indirect. Women did get support and sympathy from each other, and sometimes work opportunities, too, but female groups and networks were too weak to effectively assist their members up the professional ladder. As Ulla Vuorela noted when she studied Hilma Granqvist's career, even strong all-female social networks could not compensate for the lack of male networks in the professional context. ${ }^{24}$

To recapitulate, the core contribution of the group biographical approach is that it allows us to study the interaction between individuals and to explore the implications of this interaction in the members' lives. It has the capacity to show the profound impact of long-term, significant relationships on the choices and personality of an individual. 'No man is an island', and a woman even less so.

${ }^{24}$ Vuorela 2011. 


\section{Individual biography in the study of gender, knowledge and power}

My research project on early medical women contained streaks of individual biography: I followed some members of the set for the whole or much of their lives. I would have liked to choose women whose career patterns were in some way exceptionally interesting. In practice, however, the choice was dictated by what Christina Florin once called the 'thick file principle', i.e. fell on those women who had happened to leave major collections of source material in public archives. There were half a dozen of them, which is not much in a set of 85 women. This is probably not a coincidence. Mineke Bosch encountered a similar dearth of source material when she studied women of science. She notes: 'As a historian of women, gender, and science, I have often despaired at the lack of personal archives of women scientists or higher-educated professional women. This rather systematic policy of erasure is in sharp contrast to the way in which suffrage feminists orchestrated their memoires.' ${ }^{25}$

One consequence of moving from sets and groups to individuals is a wider view on agency. In the set biographical analysis, many of the women physicians seemed curiously passive. They did not hold any offices or publish any research, and there is no information on their practice. However, ego-documents showed that many of them were in fact very active, but in ways and areas that left little or no trace in official records. Some of them dedicated much of their time to their families and households and practiced medicine part-time, while others were active in various societies and associations. The line that separated voluntary from salaried work was sometimes blurred, for instance when a physician did medical work for and within various organisations.

Source material related to specific individuals also gave me opportunities to study the grass-root experience of medical work. ${ }^{26}$ In early twen-

${ }^{25}$ Bosch 2009, 37, note 55

26 "Agency" and "experience" have been referred to as the intersection of structures and individual choices. On the concept of agency as an intermediator between social change and personal history, see Heinz and Krüger 2001, 41. According to Ville Kivimäki, 'the concept of experience can be understood as a point of intersection between the social structures and the subject, between the objective and the subjective reality' (Kivimäki 2006, 4.) 
tieth-century Finland medical work was tangible and down-to-earth. It often involved physical strain and exertion, required artisanal skill and the use of the five senses. During the interwar period, when the majority of the women of the index set were professionally active, diagnostic and therapeutic methods were crude if not primitive by present standards. Specialisation was taking its first steps, and the hospital network was not particularly dense. Communal physicians, the most numerous section of the profession, were jacks of all medical trades: they prescribed medicines, extracted teeth, operated for hernia and of course assisted in childbirths. The hands-on practical realities of medical work came to the fore in letters, especially in those written to colleagues.

Above all, however, the biographical approach contributed to the problematics of gender and power by allowing long-term observation of individual lives. Both the range of possibilities and the actual choices made by an individual are strongly influenced by her previous choices and experiences. I wondered, for example, why Anni Seppänen (18951979), who had taught for years at a university clinic and published a substantial amount of research never applied for an adjunct professorship. The fact that I had followed her life course from her school years to adulthood through her diaries and letters made it easier for me to decide how much weight I should place on her character and upbringing, how much on the way she had been socialised to the female role by her family and school, how much on her more immediate personal goals and wishes, how much on overt and covert mechanisms of power and segregation and how much on coincidental factors.

Indeed, it counts as one of the central observations of my study that the gender inequality that was so obvious on a statistical level in the early twentieth-century Finnish academic world was built on the accumulated effects of small, often overlooked mechanisms of segregation rather than on grand discriminatory gestures or open exclusion. It would not have been possible to notice these long-term accumulations and their effects if I had only studied sets or groups of women and not also followed some individuals' lives and careers at close range for decades. 


\section{Bibliography}

Berg, Annika et al. (eds): Par i vetenskap och politik. Intellektuella äktenskap i moderniteten. Borea, Umeå 2011.

Bertaux, Daniel (ed): Biography and Society: The Life History Approach in the Social Sciences. Sage, London 1981.

Bruneau, William: Toward a New Collective Biography: The University of British Columbia Professoriate 1915-1945. Canadian Journal of Education 1 (1994), 65-79.

Bosch, Mineke and Kloosterman, Annemarie: Politics and Friendship: Letters from the International Woman Suffrage Alliance, 1902-1943. Ohio State University, Columbus 1990.

Pycior, Helen et al. (eds): Creative Couples in the Sciences. Rutgers University Press, New Brunswick 1995.

Bosch, Mineke: Paradoxical Aspects of the Personal in Political Biography: Observations from a Dutch perspective. Journal of Women's History 4 (2009), 13-37.

Caine, Barbara: Biography and History. Palgrave Macmillan, New York 2010.

Caine, Barbara: Destined to Be Wives: The Sisters of Beatrice Webb. Clarendon Press, Oxford 1986.

Crowther, M. Anne and Dupree, Margaret W.: Medical Lives in the Age of Surgical Revolution. Cambridge University Press, Cambridge 2007.

Daston, Lorraine and Sibum, Otto: Introduction: Scientific Personae and Their Histories. Science in Context. 1-2 (2003), 1-8.

Elston, Mary Ann: Women Doctors in the British Health Services: A Sociological Study of their Careers and Opportunities. Unpublished Ph.D. thesis. University of Leeds, 1986.

Florin, Christina: Kvinnor får röst. Kön, känslor och politisk kultur i kvinnornas rösträttsrörelse. Atlas, Stockholm 2006.

Förhandlingar vid Finska Läkaresällskapets [fjärde] allmänna möte i Helsingfors den 28 och 29 Maj 1873. J.C. Frenckell \& Son, Helsingfors 1875.

Förhandlingar vid Finska Läkaresällskapets sjuttonde allmänna möte i Helsingfors den 21, 22 och 23 september 1899. Helsingfors Centraltryckeri, Helsingfors 1900.

Hakosalo, Heini: Elsa Ryti ja naisen mahdollisuudet 1920-luvun suomalaisessa lääketieteessä. Historiallinen Aikakauskirja. 1 (2012a), 35-50.

Hakosalo, Heini: The Ryti Case: Language, Gender and the Rules of the Game in Finnish Academic Medicine in the 1920s. Scandinavian Journal of History. 4 (2012b), 430-460.

Hakosalo, Heini: Tasohyppelyä. Varhaiset suomalaiset lääkärinaiset ja biografisen tutkimuksen monimuotoisuus. Historiallinen elämä. Biografia ja historiantutkimus. Eds. Heini Hakosalo, Seija Jalagin, Marianne Junila and Heidi Kurvinen. SKS, Helsinki 2014a, 45-61.

Hakosalo, Heini: Naisten ääni. Varhaiset suomalaiset naislääkärit lääketieteellisen keskustelun kentillä. Hippokrates. Suomen lääketieteen historian seura vuosikirja. 29 (2014b), 113-138.

Hakosalo, Heini: 'Our Life Work': Professional Women and Christian Values in Early 20thCentury Finland. Between Ancestors and Angels: Finnish Women Making Religion. Eds. Terhi Utriainen \& Päivi Salmesvuori. Palgrave Macmillan, New York 2014c, 83-102.

Hakosalo, Heini: Modest Witness to Modernization: Finland Meets Ovamboland in Mission Doctor Selma Rainio's Family Letters, 1921-32. Scandinavian Journal of History 2015a, 298-331.

Hakosalo, Heini: Elin och Ille. Syskon, kön och medicinsk karriär i det tidiga 1900-talets Finland. Historisk Tidskrift för Finland. 2 (2015b), 125-160. 
Hakosalo, Heini: Lääkäri Rosina Heikel. Pitkänmatkanjuoksijan yksinäisyys. Naisten aika. Valkoinen varis ja muita oppineita naisia. Eds. Riitta Mäkinen and Marja Engman. Gaudeamus, Helsinki 2015c, 21-36.

Hakosalo, Heini: Tohtori Karolina Eskelin. Kirurgiaa ja kansanvalistusta. Naisten aika. Valkoinen varis ja muita oppineita naisia. Eds. Riitta Mäkinen and Marja Engman. Gaudeamus, Helsinki 2015d, 192-207.

Jones, Diana K.: Researching Groups of Lives: A Collective Biographical Perspective on the Protestant Ethic Debate. Qualitative Research. 3 (2001), 325-346.

Kragh, Helge: An Introduction to the Historiography of Science. Cambridge University Press, Cambridge 1991.

Keats-Rohan, Katharine B.: Progress or Perversion? Current Issues in Prosopography: An Introduction. (2004), at the web page of the Unit for Prosopographical Research, Linacre College, Oxford. http://users.ox.ac.uk/ prosop/

Kivimäki, Ville: The Concept of Experience in Studying Men. Ennen \& nyt-Historian tietosanomat 3-4/2006.

Kusch, Martin: Foucault's Strata and Fields: An Investigation into Archaeological and Genealogical Science Studies. Kluwer Academic Publishers, Dordrecht 1991.

Leskelä-Kärki, Maarit: Kirjoittaen maailmassa. Krohnin sisaret ja kirjallinen elämä. SKS, Helsinki 2006.

Lund, Stig (ed): Suomen hammaslääkärit = Finlands tandläkare [unknown publisher, 1928].

Martin, Jane: Hope of Biography: The Historical Recovery of Women Educator Activists. History of Education 2/2003, 219-232.

Merton, Robert K.: Science, Technology and Society in Seventeenth-Century England. Osiris. 4 (1938), 360-632.

Nasaw, David: Historian and Biography: Introduction. American Historical Review. June 2009, 573-578.

Söderqvist, Thomas (ed): The History and Poetics of Scientific Biography. Ashgate, Aldershot 2007.

Shortland, Michael and Yeo, Richard (eds): Telling Lives in Science: Essays on Scientific Biography. Cambridge University Press, Cambridge 1996.

Sana, Elina: Luovutetut. Suomen ihmisluovutukset Gestapolle. WSOY, Helsinki 2003.

Shapin, Steven and Thackray, Arnold: Prosopography as a Research Tool in History of Science: The British Scientific Community 1700-1800. History of Science. 12 (1974), 1-28.

Uotila, Merja: Tavallisuuden tavoittelua. Prosopografia elämäkerrallisen tutkimuksen välineenä. Historiallinen elämä. Historiantutkimus ja biografia. Eds. Heini Hakosalo, Seija Jalagin, Marianne Junila and Heidi Kurvinen. SKS, Helsinki 2014, 240-256.

Vilén, Timo: Ragnar Granitin Nobel-ura. Tutkimus tieteen palkinnoista ja palkintojen tieteestä. SKS, Helsinki 2013.

Vuorela, Ulla: Vapaan tutkijan merkittävät toiset - näkökulma Hilma Granqvistin tutkijanuraan. A paper read at the research seminar of the Kristiina Institute at the University of Helsinki, Finland, 15 February 2011.

\section{Internet sources}

http://vesta.narc.fi/cgi-bin/db2www/sotasurmaetusivu/main 


\title{
Bad girl biographies: \\ Child welfare documents as gendered biographies
}

\author{
Kaisa Vehkalahti
}

Question no 12. Where has the person to be investigated been brought up? Until which age has she lived with her parents? From which age has she had a stepfather or a stepmother? Has she been given out or placed out in fostering, or has she been adopted by court decision, when? When and where has she been placed in a child welfare institution, child psychiatric institution, reception home, hospital etc? To be listed in chronological order. Has she been neglected without care; when and where?

When trying to grasp the life stories of ordinary or marginal people that have left no written sources of their own, historians often have to turn to sources produced for administrative purposes. In so doing, we make use of biographical material more often than we realise. We deal with a variety of documents that include biographical descriptions and interpretations, and we work with professional practices that have involved multiple uses of biographical information. The collection, filing and processing of biographical data has played a key role in several modern

1 (Form for preliminary investigation no 1 / Child welfare form no 10, 1960). The translations of the questions, originally in Finnish, are made by KV. 
welfare professions. In this chapter, I wish to pay attention to one of these arenas of knowledge production and creation of administrative biographies, namely child welfare social work.

The above quoted questions are included in the form for personal investigation used in Finnish social work from the mid-1940s onwards. Through narrative analysis of this one particular form and its uses, I wish to take a closer look at the historical connections between telling life stories and producing knowledge for administrative purposes. What kind of historical sources are biographies constructed for administrative purposes, such as in child welfare proceedings, and how can we use them in historical research? Could biographical approaches help us in opening new perspectives to the history of modern child welfare?

The primary sources of the chapter are collected from the municipal child welfare archives of two mid-sized Finnish cities located in Northern and Southern Finland. Both of the cities were regional centres in their areas, characterised by industrialisation and the steady growth of population during the post-war decades (population in 1960: northern city ca 55000 and southern city ca 125000 ). The archived personal investigations discussed in this chapter are related to the cases of teenage girls, who were subjected to child welfare and police proceedings due to their own behaviour, which was, for one reason or another, viewed as 'delinquent' or 'wayward', or who violated the norms set by their parents or authorities such as schools, the police and the child welfare officials. They were born between 1927-1957 and subjected to child welfare proceedings when aged $12-18$ years.

However, in this chapter the focus is not so much on the girls and their individual stories, but rather on the professional tool that was used for compiling their official biographies. I will first turn to the historical connections between telling life stories and producing knowledge for administrative purposes. The pre-structured forms that serve as the basis for this chapter were used for several decades and their design can be observed as quite typical for the era and its' administrative practices. The case analysis of the forms focuses on three elements: How did the investigation forms structure the biographies told within them? What kinds of identity positions were offered for the characters of the biographies - the bad girls and their families? And finally, from what kind 
of legal and professional background was the biographical gaze motivated? The chapter will conclude with a discussion about biographies constructed for administrative purposes as historical sources.

\section{Administrative history and narrative models of life narratives}

Carolyn Steedman has pointed at the historical links between administrative needs and narrative models of life writing. She has paid attention to the autobiographical practices operating in different fields of emerging administration. In particular, she points at poor-relief proceedings as an important arena, in which patterns for telling life stories were created. Steedman goes as far as to suggest that the modern literary articulation of selfhood and character has its origins among the poor. At least from the seventeenth century onward, hundreds of thousands of English men and women became familiar with talking about their lives from a fixed standpoint and in chronological sequence, when they were required to present magistrates with information about the earlier parts of their lives. In addition to learning what constituted the key elements in an acceptable autobiography, ordinary people became familiar with having their stories recorded. ${ }^{2}$

Steedman draws attention to the fact that many seemingly autobiographical accounts that are transcribed and recorded in the archives are, in fact, enforced, as they are produced on demand and along with expectations set by the authoritative context in questions, such as a magistrate or courtroom. Steedman is widely credited for broadening our understanding of autobiographical writing as a historical genre ${ }^{3}$ However, bearing in mind the underlying difference between autobiographical and biographical writing - stories told by the person who lived the life and by someone else ${ }^{4}-$ it is fruitful to reconsider the enforced models of life writing from the perspective of biographical writing. In

\footnotetext{
${ }^{2}$ Steedman 2000; 2001, 45-55.

${ }^{3}$ Stanley 2000; Vehkalahti 2009; Ahlbeck-Rehn 2011, 229-230.

${ }^{4}$ Possing 2012, 33.
} 
addition to the life stories transcribed as first-hand testimonies and personal statements, the same administrative archives offer us plenty of evidence about how personal information has been used for composing authoritative biographies about other people in the magistrates, courtrooms, hospitals and so on.

In his ground-breaking work Rewriting the Soul. Multiple Personality and the Sciences of Memory (1995), Ian Hacking uses the concept sciences of memory to describe how memory became to be understood as 'a scientific key to the soul' in the latter part of the nineteenth century. The process, in which personality and morals were increasingly viewed from a biographical perspective, through the earlier life of the person, gave rise to an intensified urge for biographical knowledge in the Western societies. Personal identity and biography were linked intimately. ${ }^{5}$ According to Hacking, this development set grounds for several emerging fields of science, such as anthropology, sociology and psychology, that based their professionalism on multiple techniques to investigate memory. The dynamic relations between 'people who are known about, the knowledge about them, and the knowers' also involved the emergence of new kinds of truths and falsehoods, as well as new objects of knowledge. ${ }^{6}$

In her study about the life narratives of female mental patients, constructed in the framework of early twentieth century medical discourse, Jutta Ahlbeck points out how the life stories produced by questioning and transcribing the stories of patients was an integral part of the process of diagnosing. By analysing how certain interpretations of the histories of female patients came to be understood as fact in the psychiatric discourse while others were surpassed, she makes the underlying power relations visible. ${ }^{7}$ As Birgitta Svensson points out, this urge for biographical knowledge did not cease in the twentieth century, quite the opposite. Biographies composed for scientific and administrative purposes have only taken new forms, becoming more systematic and formalised. ${ }^{8}$

\footnotetext{
5 See also Larsson 2001, 245; Svensson 2011, 26-27.

${ }^{6}$ Hacking 1995, 6, 198.

${ }^{7}$ Ahlbeck-Rehn 2006; 2011, 234-235, 239-240.

${ }^{8}$ Svensson 2011, 36-37.
} 
The history of social work can also be viewed in this continuum as one of those professional practices of modernity that made use of biographical investigations or the 'sciences of memory'. According to Michel Foucault, the production of truth lies in the core of power relations embedded in modern professions, as power lies in the capability of producing 'truth' and defining what is understood as true at different times. ${ }^{9}$ Following this view, the compiling of personal information and summarising it into a biography can be viewed as an important technique for enforcing the truth about the subjects of the procedures. Close analysis of documentation practices may offer important insights both into the underlying power structures and into professional development. In social work, record-keeping became the formalised way of both knowing and expressing individual biographies in a professionally translated and abridged version. Moreover, as several historians of social work have pointed out, record-keeping provided an essential prerequisite for professional development in the field during the twentieth century. Along with the emergence of modern legislation, social work professions and vocational education, record-keeping has played an essential role in the development of social casework as a method. The development of professional language and creation of manuals and guidelines, forms, registers, card files and other practical tools that guided the social workers on the local level all represented crucial steps in the professionalisation of the field. As the tasks and the role of social work became more established, social work practices became more and more textual. Documentation gained a crucial role in legitimatising the emerging field in relation to competing professions that had a longer professional history. ${ }^{10}$

In Finland, the era from the 1920s to the late 1960s has been described as a shift from local experience-based knowledge to national, standardised methods of social work. As Finnish researchers of social work, Mirja Satka and Timo Toikko have pointed out, the development of the field was characterised by a dual process: on one hand, the legislative initiatives (such as the renewal of Poor Law in 1922 and Child Protection Law in 1936) underlined the juridical and administrative elements of

\footnotetext{
${ }^{9}$ Foucault 1998 (1976); Gordon 1980, 193.

${ }^{10}$ Satka 1995; Tice 1998; Hämäläinen 2007.
} 
social work, involving hierarchical control mechanisms and municipal administration. On the other hand, the development of casework as a method of social work started to gain a foothold. The pioneers of social work, who had been educated in the United States, spread the idea to Finland, for example, within the newly established vocational education of social workers. Intensified pressure to delimit and standardise the working methods of municipal agents (such as boards, trustees and individual workers in municipalities) particularly underlined the importance of documentation. ${ }^{11}$

'Making a child welfare case' is essentially about constructing and telling biographies. The construction of life stories can be seen both as a method of case working and as a result of the process. Firstly, the gathering of biographical information from various sources was the most essential and common method of case working at the dawn of modern social work, and continued to be throughout the post-war era. It preceded other measures, such as psychological testing and consultation that became more common after the Second World War. Secondly, the information that was collected from various informants was arranged in the form of a linear biography - and recorded in a way that justified the suggested child welfare proceedings. Thirdly, the 'biographies' that are constructed this way - such as statements written by child welfare officials and forms of personal information - constitute the documentation of the case. Hence, the biographies and traces of biographical processes in work is what actually remains in the archives for later research.

Investigations into the circumstances, character and life of delinquent girls

The first version of the form for personal investigation was introduced during the Second World War, when legislation concerning young (15-21 years old) offenders was reformed in Finland. The Law on Young Offenders was decreed in 1940, and it was followed by a statute in 1942

${ }^{11}$ Satka 1995; Toikko 2005, 25-28, 146-147; Juhila 2006, 31-36. 
(263/1940; 1001/1942.) One of the novelties introduced in this legislation was the concept of young offender. It was used to refer to young people who were considered criminally responsible (over 15 years) but who should still be treated differently from adult offenders (over 22 years). The law obligated courts and prosecutors to co-operate with social work and child welfare officials, and the form for personal investigation was designed to meet this juridical need. ${ }^{12}$

The pre-structured form included 51 questions aimed at mapping background, personal development, delinquent behaviour and the circumstances in which the young offender lived. The investigation was carried out by a child welfare social worker and the form was presented as an official document when the young person was tried in the court of justice. However, the same tool was also adopted for other purposes within child welfare social work. The very same form was used, for example, when placement in a children's home, reform school or similar institution was considered, or if the surveillance of the young person was under consideration. This means that within social work, the use of the investigation form was, in practice, much broader, and the same questions, originally designed for young offenders, could also be applied to children who were considerably younger that fifteen.

Hence, the purpose and the legal status of the archived personal investigation forms is two-fold: On the one hand, there are investigations carried out in connection with juvenile crime cases, where the juridical use placed the evaluations and suggestions by social workers in a particularly careful context. On the other hand, there are investigations that were initialised by motives related to child welfare work, and where the same document - the investigation form - did not have the same legal status. This underlying difference is important, as it frames the life stories created through these processes in different contexts. It has to be noted, however, that there were always some specific reasons leading to this procedure, even if it was carried out as a child welfare procedure. In most of the cases concerning teenage girls, these grounds were connected to the need to place the girl either in supervision or in reform

${ }^{12}$ Harrikari 2004, 189, 195. For war-time development in social policy see also Laurent 2012. 
school. The investigation was carried out to provide grounds for the suggested child welfare measures. In addition, in both cases, the forms have been filled in by the same municipal child welfare social workers.

The first version of the form included six pages, divided in five sections concerning 1) family relations; 2) home conditions; 3) the physical and mental development of the young person and her lifestyle, including schooling and employment; 4) actions concerning the care and the custody of the young person. At the turn of the 1940s and 1950s, the form was revised several times, each version adding new and more detailed questions. Since 1949, the last two sections were replaced by separate sections concerning 3) childhood development and schooling; 4) employment; 5) recent circumstances and life events; 6) crimes and 7) suggestions concerning the future care of the young person. This eight-page version with 71 questions became quite long-standing, as only minor alterations appeared by the end of the 1960s.

The list of questions is revealing about how young delinquents were viewed and what kind of criteria was used when defining them: age, family background, childhood development and circumstances, experiences at school and in employment. They set the biographical framework in which the delinquent behaviour was contextualised. These were the main areas of interest to which the attention of the investigating social worker was directed and which were anticipated to constitute the decisive elements of the case. In principle, there was nothing new about framing juvenile delinquency this way. Similar biographical elements can be found in different documents related to juvenile crime cases and reform school placements since the beginning of the twentieth century. ${ }^{13}$ What was new was the standardised way of collecting and documenting this data. The pre-structured form was more detailed, and the options offered to the social workers left no room for the lavish and elaborate reports that can be found among the early-twentieth century documents. The form compelled the social workers to follow a certain list. Evaluation of different areas could take different directions, allowing contradictory views to be voiced. The outcome of this type of

${ }^{13}$ Vehkalahti 2009. 
investigation was, at the same time, more detailed, more fragmented and multivocal compared to earlier forms of documentation.

The aim of standardisation and professionalisation is manifested most clearly in the comparison of the 1944 and 1949 versions. Most of the original questions were multiple choice questions in the sense that they included several sequential definitions or options that the answering social worker could choose, but by 1949, these lists of options had grown even more systematic and detailed. The guidelines printed in the investigation form underlined objectivity and clarity. Information had to be collected from the closest relatives of the young person, preferably her parents or the custodian. Particularly mothers' judgements, worries and wishes dominated the forms of the 1950s and 1960s. Depending on the case, older siblings', grandparents' or other relatives' views were accounted to offer further evidence or to contrast the opinions of the parents. Information concerning schooling, medical care, employment, encounters with the police and previous institutional history were preferably collected directly from the institutions in question, but, in practice, it was common that parents provided this information as well. The importance of hearing other professionals was underlined in the later versions of the form, which included, for example, specific questions concerning teacher's opinions about the young person. The act of hearing from the young people themselves, however, was not required. Occasionally, the girls' own opinions (and more often others' accounts of their sayings) have been recorded in these forms, but, in principle, they were interviewed outside of this protocol. ${ }^{14}$

The absence of the voices of the young people was reinforced by the practical nature and the circumstances framing the personal investigations. Often the investigation was carried out in a situation in which the girl herself had run away and the caretakers had no idea where she might be. For the sake of clarity and further uses of the form, the questionnaire was advised to be filled in a way that later readers did not have to read through all the detailed questions presented in the margins, but could

${ }^{14}$ There was a supplementing form designed for the young people to answer, but the real usage and the importance of these forms remains vague as practically no forms filled in by the girls themselves have survived in the archives of the two cities included in this study. 
obtain all the essential information by scanning through the answers alone - yet another attribute that brings the forms closer to the more traditional forms of biographical narration.

Even though documentation practices changed through the standardisation and professionalisation of practices, there are some strong continuities. What is common for early-twentieth century documentation and the standardised forms of the 1940s is their problem-centred focus. Documents continued to be structured around those issues that were considered to be problems in the life of the young person. Evidence was collected and presented in order to justify the need to interfere in the situation of the young person. In the following, I will discuss the biographical interpretations suggested by the form by focusing on three elements: parental relations, positions offered for the young people and the narrative structure of the forms.

Biographical interpretations suggested by the investigation form

The first two sections of the form for personal investigation contextualised the young person in her family. This involved mapping her origin and an evaluation of both biological parents and other caretakers (foster homes etc.), as well as the siblings and close relatives. Questions concerning home and family are indicative of the problem-centred focus. The form can be read as a detailed list of possible home-related problems from among which the social workers could choose. The form included very detailed questions about the parents' character and their reputation and style of life. Moreover, the possible indicators suggested for fathers and mothers involve interesting gendered differences (see the text in Italics). As for the fathers, the emphasis was clearly placed on his role as the supporter of the family:

Question 8: Father's lifestyle and character. Has the lifestyle of the father, or the alleged father, been regular and has he taken care of his family? If he has been obligated to provide support due to, for example, divorce or for an illegitimate child, has he fulfilled his obligation? 
Recommendable to mention characteristics. Has he been convicted; when, what for? Is he a drinker, has he lead a vagabonding life, has he neglected to support his family? Has he been in institutional care?

Question 9: Mother's lifestyle and character. Has the lifestyle of the mother been regular and has she taken care of her family? Recommendable to mention characteristics. Has she been convicted; when, what for? Has she been drinking, or has she lead a vagrant life? Has she been in institutional care?

Possible physical and mental health problems running in the family, criminality and the use of alcohol constituted the three most central home-related elements that were assumed to play a role. In addition, the form directed the social workers' attention to the relationship between the parents, and between the parents and their children. Finally, the caretakers' employment, their financial situation and possible earlier use of social benefits were included in the questions. Particular attention was paid at investigating how the young person had been treated at home and in other places of residence with the idea of finding out if she had been exposed to harmful conditions and models for deviant and delinquent behaviour.

This problem-seeking agenda, together with questions formulated in the form of pre-given categories, have contributed to the fact that the biographies are long, detailed and informative in the cases where the social workers detected problems, whereas the biographies of those girls whose family relations were not characterised by the anticipated problems can be very exiguous and inexpressive. The profile of a decent father is reduced to the image of a working man who is capable of providing for his family: 'The way of life of the father of the person to be investigated is regular and he is attentive to his family. ${ }^{15}$ The profile of a good mother could be equally vague, 'There is nothing specific to note about the mother ${ }^{16}$, or formalistic 'Mother's way of life is decent and she

${ }^{15}$ Investigation 1962, person to be investigated born in 1947.

${ }^{16}$ Investigation 1945, b. 1927. 
is a hard-working mother of the family'17. In addition to more visible signs of a 'bad reputation', such as criminality and alcoholism, the form directed social workers' attention to the mental state of the home. Both hidden and explicit criticism, as well as suspicion towards the parents can be read in the social worker's short evaluations: 'The mother of the person to be investigated is very nervous. She is constantly on tranquillizers. She has not been committed for any crimes. In terms of her character, she is a person who overemphasises things and is not able to concentrate. $^{18}$

On the other hand, however, many parents instigated the child welfare process that led to the investigation, and they are portrayed as co-operators for the officials. In these cases, the forms often display compassion and alignment with the anxious parents. What is particularly typical is the social workers' compassionate alignment with the mothers. There is a gendered constellation of parental relations that can be found in several proceedings: a mother, who is 'doing her best' for the children and a father, who is either sick, drunk, violent, absent or causes other problems. Mothers' suspicions, their feelings of insecurity, frustration and fear are clearly given room in the investigations.

The order of the questions strongly suggested a biographical approach, in which the forthcoming problematic situation was explained primarily by earlier neglect, bad example or ill-treatment by the adults close to the child. The pre-given structure, in itself, is likely to create a certain atmosphere of drama in the forms. Two narrative structures - or plots - are particularly typical. First, there are biographies presented in the form of an accumulating circle of problems paving the way to the current crisis and to the need to interfere in the life of the young girl. Secondly, there are cases that involve more abrupt changes: the earlier childhood development may have been described with positive records concerning the parents, home-education, schooling, and even with good reports given by the girls' employers. Changes, breaks and turns in these biographies are often linked to some sudden life events or influence by other people. Perhaps, most typically, the changes are brought about by associations with men or by slipping into 'bad company', which eventu-

\footnotetext{
17 Investigation 1965, b. 1951.

${ }^{18}$ Investigation 1969, b. 1952.
} 
ally prompts concern over the moral and sexual development of the girl in question and intensifies the need to interfere in her life.

The problem-seeking approach of the personal investigations had its roots in the Statute on young offenders $(2 \$, 1001 / 1942)$ that set the guidelines for the procedure. According to the statute, the personal investigation should be directed at the 'physical, intellectual and moral development' of the young person, especially concerning 'those features in his character that may have led him to crime.' When investigating the life of the young person and the circumstance leading to the crime, particular attention should be directed at investigating whether there had been 'criminality, other forms of delinquency or insanity' in the family of the young person to be investigated. ${ }^{19}$

The legislative text guided the officials to evaluate whether the delinquent behaviour was caused and produced by disadvantageous circumstances and it divided the young offenders into three categories:

1) those young people whose criminal and delinquent behaviour mainly resulted from circumstances,

2) those who had committed the crime due to a 'sudden emotional outburst', 'defiant reaction' or similar contradictory state of mind, and finally

3) those young people whose behaviour was connected to more permanent deviation and inborn character.

Hence, the biographical approach and interpretation reflected in the structure of the personal investigation form was motivated by the underlying legislation. The focus on the influence of the family - both social and biological - was in line with the long-held approach to juvenile criminality. In the early-twentieth century documentation, parents are often blamed for their daughter's problems and the mothers could be depicted as the source of 'moral corruption' in quite a drastic way ${ }^{20}$. However, what can also be heard in the formulations of the 1942 Statute on young offenders are echoes of the 1930s' ideas concerning heredity and degeneration. Timo Harrikari has called the second section of the statute a 'degeneration section', because it put so much emphasis

${ }^{19}$ See also Harrikari 2004, 195-197; Pekkarinen 2010, 92-93.

${ }^{20}$ Vehkalahti 2009. 
on detecting possible moral degeneration in the family. This view on juvenile delinquency had been prominent in the 1937 committee set for planning the legislation concerning young offenders. The committee consisted of professionals of jurisprudence, psychiatry and prison administration, which is reflected in the report that is dominated by a psychiatric view on juvenile delinquency, as well as by attempts to categorise different types of offenders. These prevailing approaches to juvenile delinquency are also reflected in the formulation of the personal investigation form. ${ }^{21}$

The strong interest to sort out those young people whose delinquency was perceived as inborn and more permanent is reflected, interestingly, in the positions reserved for the young people themselves in their biographies. The way of conceptualizing the possible social roles of the young people in the context of schooling, and later in relation to friends, is a good example of this approach:

Question 32 Relations to other pupils: Is the person, for example, lonesome, fearful, shy; teasing; friendly, helpful, popular among other pupils, a leader, easily led by other people? What kind of company did she seek? (Investigation 1952)

Question 49: Circle of friends: What information is there about the friends of the person to be investigated? Usual places where they spend time. Bad or good company? Is she a leader, easily led by other people? Has she been warned about certain friends? Relations to the opposite sex. (Investigation 1952)

Two identity positions, in particular, can be sketched out: the leaders and the followers - those who caused trouble and those whose behaviour was viewed as resulting from circumstances and a bad example. Firstly, there are girls who are defined as followers among their peers and are vulnerable to the 'seduction' provided typically by other girls, boys, men or older women with a 'bad reputation'. In this category of life narratives, it is most often the impulses from outside of the family that

${ }^{21}$ Harrikari 2004, 189-192, 196. 
generate problems, and particularly an association with boys and men. The concept of 'bad company' appears as one of the key elements in the narratives. However, it may also be a soft and kind character that poses trouble in the case of the followers:

Question 34: 'The person to be investigated seems to be rather kind in terms of her character, although her mother insists that she has lately become more stubborn and disobedient. Occasionally, the person to be investigated seems rather talkative, she likes to 'explain' things. She appears to be easily led, which may explain partly why she has ended up in the sexual adventures.' (Investigation 1956, b. 1942)

Leaders referred to girls who appeared to be independent, had lots of friends and who appeared as the cause of the trouble rather than as bystanders: 'The person to be investigated is a leader type. She likes to gather around her admiring listeners. She teases her friends. ${ }^{22}$ Many of the 'leaders' were reported as hanging around in the company of boys (for example, in gangs that committed crimes). Not surprisingly, an association with boys aroused worries about promiscuous sexual behaviour, as was the case in the previous quote. It is interesting to notice that the investigation form did not involve any gender-specific questions concerning either signs of delinquency or personal development. Whether this was due to the aim of standardised working methods or to the fact that girls constituted a very small minority of all young offenders, the investigation form nevertheless offered the same definitions for both boys and girls. The social workers, however, had many opportunities to gender their reports, as can be seen in the surviving documentation.

The categories of followers and leaders were first introduced in the 1949 version of the questionnaire. The emergence of these categories reflects the increasingly psychological view on youth problems, which can be detected in several sections of the form: questions concerning the intelligence and abilities of the young people changed considerably; revised questions concerning the early childhood development of the young person referred to influences from developmental psychology.

${ }^{22}$ Investigation 1967, b. 1953. 
The first version of the form had presented the social workers with a straightforward set of attributes aimed at sketching the character of the young person. The later version of the same question took a more nuanced approach, demanding the social workers to record both parents' and teachers' evaluations concerning the character of the young person, as well as to note positive characteristics:

13: How is she in terms of her character? (open-minded, sprightly, lively - withdrawn, sullen, nonchalant; calm, even-tempered - quarrelsome, hot-tempered; warm-hearted, sensitive - cruel, cold; straight, honest, fair-minded - insidious, dishonest, liar, selfish; submissive, humble reluctant, defiant.) (Investigation 1947)

34: 'Character. What do the parents say about the character of the person under investigation? What do the teachers say? It is recommended to illuminate the character with some examples. Particular attention should be paid to those character traits that may have led the person under investigation into crime or other kind of delinquency. Her positive characteristics should also be accounted for.' (Investigation 1952)

While the discourse on juvenile delinquency took a swift turn towards the psychological and social understanding of young people and their problems, this took place within the limitations of the leading questions that originated from the legislative texts of the late 1930s and early 1940s. They still set the framework for personal investigations up until the end of the 1960s.

\section{Conclusion}

What kind of historical sources are biographies constructed for administrative purposes? First of all, it is important to note that administrative records do not reveal the past - just like there are no other sources that would reveal the past such as it was. Italian microhistorian Carlo 
Ginzburg has aptly concluded that many historical texts tell more about the person who wrote them than about the historical reality the texts were set to describe. ${ }^{23}$ Child welfare documents do not offer neutral information about the lives of the children and families depicted in them. As formal, objective and impersonal as they aim to be, social work documentation should not be taken as accounts of lives as they were lived. Rather, they have been created for certain purposes and they contain information selected from this point of departure, as has been shown in this article. Power relations between the child welfare authorities and their clients are always present in this type of documentation. ${ }^{24}$

By a close reading of the personal investigation forms used in the trials of young offenders and in child welfare social work in the 1940s and 1960s, this article has shown how the very tools used in everyday social work practices steered the documentation towards some pre-given interpretations of youth delinquency. The biographical gaze embedded in the investigation tools had its roots in the prevailing views on criminality and heredity, intertwined with the increasingly psychological and social view of interpretation regarding juvenile delinquency. Pre-given categories used when evaluating, for example, family relations or young peoples' social roles and character are illuminating about the post-war practices for policing the youth. I would argue that a biographical approach may open important new insight in terms of the critical reading of administrative sources. By paying special attention to the process of constructing biographies that came to be understood as factual, we may better understand the administrative mechanisms, such as the development of social work. Close narrative readings enable us to see that even the most formal resolutions, forms and records may be revealing about how childhood and youth were understood in the society. However, the article does not argue that social work documentation would have no relation to the lives and the experiences of those people described in them. On the contrary, they may have had enormous consequences in

\footnotetext{
${ }^{23}$ Ginzburg 2012, 3.

${ }^{24}$ Kääriäinen 2003; Dominelli 2005; Billquist and Johnsson 2007; MacDonald 2008; Laine and Saurama 2009.
} 
the 'real lives' of their subjects, as they were often decisive in defining not only the past, but also the future of the young person.

How then can we use sources like personal investigation forms in biographical research? Following the abovementioned reservations, it is important to note that it is only the administrative biography that can be formulated through administrative sources, not a holistic biography seeking to understand the ways in which the subjects of the administrative documents experienced and understood the world in which they lived. Therefore, the use of administrative documentation in biographical research, as inspired by 'new social history', microhistory, gender history or post-colonial history, is rather complex. ${ }^{25}$

Administrative sources do constitute an important set of sources available for research, but it is vitally important to pay attention to the administrative aims set for them and to the narrative patterns created by different working methods and devices. When read against material produced under different conditions about the same persons, the scripted patterns produced by the administrative context may be overcome. Secondly, administrative archives offer us fruitful material for biographical approaches that look beyond individual experiences and meaning, such as collective biographies or group biographies. If we follow Barbara Caine's broad definition of collective biography as a continuum, extending from 'individual studies which are grouped together to make up a collective' to those works in which 'the primary subject is a group of people and which focus on the interactions and shared experiences of its members', the possibilities for studies relying on administrative archives are much wider. ${ }^{26}$ The careful cross-reading and comparison of several micro cases, by means of a comparative or collective study, opens insightful views to the shared experiences, living conditions and life courses of the teenage girls subjected to child welfare proceedings in post-war Finland - even though the 'genuine' thoughts and intentions of each individual remain beyond reach.

Finally, it is important to acknowledge that, despite their biased focus, administrative biographical sources may, sometimes, be indis-

${ }^{25}$ Caine 2010, 3.

${ }^{26}$ Caine 2010, 48 
pensably important for those individuals and families that do not have other written material about their life history. Children, for example, who have been placed in out-of-home-care often have no photo albums, letters, keepsakes or access to oral family stories that would enable them to connect with their roots. As several studies have shown ${ }^{27}$, child welfare records and other administrative archives may, in these cases, function as important repositories of the family history.

\section{Bibliography}

\section{Archives}

City Archives of Turku

Board of social welfare, Department of child welfare

Forms for preliminary investigation, 1945-1969

City Archives of Oulu

Board of Child Welfare

Case files of children taken into custody 1945-1969

\section{Literature}

Ahlbeck-Rehn, Jutta: Diagnostisering och disciplinering. Medicinsk diskurs och kvinnligt vansinne på Själö hospital 1889-1944. Åbo Akademis förlag, Åbo 2006.

Ahlbeck-Rehn, Jutta: Livet som blev vetenskaplig sanning. Om framtvingade och diagnostiserade levnadsberättelser. Biografiska betydelser. Norm och erfarenhet i levnadsberättelser. Eds. Lena Marander Eklund and Ann-Catrin Östman. Gidlunds förlag, Södertälje 2011, 227-250.

Billiquist, Leila and Johnsson, Lisbeth: Sociala akter som empiri. Om möjligheter och svårigheter med att använda socialarbetares dokumentation i forskningssyfte. Socialvetenskaplig tidskrift, 2007, 3-19.

Caine, Barbara: Biography and History. Palgrave Macmillan, Houndmills, Basingstoke, Hampshire 2010.

Dominelli, Lena: Social Work Research: Contested Knowledge for Practice. Social Work Futures. Crossing Boundaries, Transforming Practice. Eds. Robert Adams, Lena Dominelli and Malcolm Payne. Palgrave Macmillan, Houndmills, Basingstoke, Hampshire 2005, 223-236.

Foucault, Michel: The History of Sexuality volume 1: The Will to Knowledge. Original: Histoire de la sexualité I: La volonté de savoir, Éditions Gallimard 1976. Transl. by Robert Hurley. Penguin Books, London 1998.

Frost, Lucy: The Politics of Writing Convict Lives: Academic Research, State Archives and Family History. Life Writing. 8:1 (2011), 19-33.

Ginzburg, Carlo: Threads and traces: true, false, fictive. Translated by Anne C. Tedeschi and John Tedeschi. University of California Press, Berkeley 2012.

${ }^{27}$ Frost 2011; Sköld, Hedström and Foberg 2012 
Gordon, Colin (ed.): Power/Knowledge: Selected Interviews and Other Writings, 1972-1977 by Michel Foucault. Pantheon Books, New York 1980.

Hacking, Ian: Rewriting the Soul. Multiple Personality and the Sciences of Memory. Princeton University Press, Princeton 1995.

Harrikari, Timo: Alaikäisyys ja rikollisuuden muuttuvat tulkinnat suomalaisessa lainsäätämiskäytännössä. Nuorisotutkimusverkosto/Nuorisotutkimusseura, Helsinki 2004.

Hämäläinen, Juha: Lastensuojelun kehityslinjoja. Tutkimus Suomen lastensuojelun aatepohjasta ja oppihistoriasta. Snellman-instituutin A-sarja 22, Kuopio 2007.

Kääriäinen, Aino: Lastensuojelun sosiaalityö asiakirjoina. Dokumentoinnin ja tiedonmuodostuksen dynamiikka. Sosiaalipolitiikan laitoksen tutkimuksia 1/2003. Helsingin yliopisto, Helsinki 2003.

Laine, Terhi and Saurama, Erja: Semiotic Analysis in the Study of Social Work. Social Work \& Society. 7:2 (2009), 261-272.

Larsson, Lisbeth: Sanning och konsekvens. Marika Stiernstedt, Ludvig Nordström och de biografiska berättelserna. Norstedts, Stockholm 2001.

Laurent, Helene: War and the Emerging Social State: Social Policy, Public Health and Citizenship in Wartime Finland. Finland in World War II. History, Memory, Interpretations. Eds. Tiina Kinnunen and Ville Kivimäki. Brill, Leiden 2012, 315-354.

Lewis, Allison: Reading and Writing the Stasi File: On the Uses and Abuses of the File as (Auto)Biography. German Life and Letters. 56:4 (2003), 377-397.

McDonald, Keith: Using documents. Researching Social Life. Ed. Nigel Gilbert. SAGE, Los Angeles 2008.

Pekkarinen, Elina: Stadilaispojat, rikokset ja lastensuojelu. Viisi tapaustutkimusta kundelta vuosikymmeneltä. Nuorisotutkimusverkosto / Nuorisotutkimusseura, Helsinki 2010.

Possing, Birgitte: Portraiture and Re-portraiture of the Political Individual in Europe. Biography as a Genre and as a Deconstructive Technique. Living Political Biography. Narrating $20^{\text {th }}$ Century European Lives. Eds. Ann-Christina Lauring Knudsen and Karen Gram-Skjoldager. Aarhus University Press, Aarhus 2012, 33-52.

Satka, Mirja: Making Social Citizenship. Conceptual Practices from the Finnish Poor Law to Professional Social Work. SoPhi, University of Jyväskylä 1995.

Sköld, Johanna; Hedström, Johanna and Foberg, Emma: Conflicting or complementing narratives? Interviewees' stories compared to their documentary records in the Swedish Inquiry on Child Abuse and Neglect in Institutions and Foster Homes. Archives and Manuscripts. 40:1 (2012), 15-28.

Stanley, Liz: From "self-made women" to "women's made selves"? Audit selves, simulation and surveillance in the rise of public women. Feminism and Autobiography. Texts, theories, methods. Eds. Tess Cosslett, Celia Lury and Penny Summerfield. Routledge, London \& New York 2000, 40-60.

Steedman, Carolyn: Enforced narratives. Stories of another self. Feminism and Autobiography. Texts, theories, methods. Eds. Tess Cosslett, Celia Lury and Penny Summerfield. Routledge, London \& New York 2000.

Steedman, Carolyn: Dust. Manchester University Press, Manchester 2001.

Svensson, Birgitta: Det moderna varat som biografisk presentation. Biografiska betydelser. Norm och erfarenhet i levnadsberättelser. Eds. Lena Marander Eklund and Ann-Catrin Östman. Gidlunds förlag, Södertälje 2011, 23-40.

Tice, Karen W.: Tales of Wayward Girls and Immoral Women. Case Records and the Professionalization of Social Work. University of Illinois Press, Urbana \& Chicago 1998.

Toikko, Timo: Sosiaalityön ideat. Johdatus sosiaalityön historiaan. Vastapaino, Tampere 2005.

Vehkalahti, Kaisa: Constructing Reformatory Identity. Girls' Reform School Education in Finland, 1893-1923. Peter Lang, London 2009. 


\title{
Afterword: Future challenges
}

\author{
Tiina Kinnunen, Maarit Leskelä-Kärki, Erla Hulda \\ Halldórsdóttir, Birgitte Possing
}

This book reflects upon the biographical turn that has influenced Nordic historical research during the past few decades. Our aim has not only been to illuminate how the new interest in biography emerged and which results have been achieved since the 1990s but also, via the case studies, to develop further the methodology of biographical research, particularly from the perspectives of gender, relationality and different life-spheres. As a result, the chapters of the book underline the variety and versatility of biographical approaches, their possibilities and challenges in telling individual life-stories and depicting historical processes.

During the past few decades, scholars interested in narrating lives have come together in both Nordic and wider international surroundings to discuss the ways in which biographies are being done. As we pointed out in the Introduction, there is nothing peculiarly Nordic in the problems and challenges we face in writing biographies - our discussions with colleagues from different parts of the world show how 
similar issues we are encountering. ${ }^{1}$ What is, though, important, is that methodological and theoretical discussions around biography within the discipline of history have been exceptionally lively and active during the past few decades, and our book indicates how the Nordic countries are part of this shared scholarship.

The chapters of the book address several aspects of biographical research and writing that we see as vital in terms of the future of biography as historical research. In addition to that, we will discuss four interrelated issues here, thus inviting biographers to rethink their work in the changing academic environment of the twenty-first century.

\section{Biography as an interdisciplinary endeavor}

Our first topic concerns the boundaries and the relationship between biographical research and other related fields of academic research on the history of individual lives. Scholarly biography is not a prerogative of historians; on the contrary, one of the future challenges for biographers is to position themselves in relation to and further develop a dialogue with this multi-disciplinary field that includes literary studies, memory studies, and life writing.

${ }^{1}$ This methodological interest in the approaches to the genre of biography was highlighted at the Roundtable in Jinan 2015 at the $22^{\text {nd }}$ International Congress of Historical Sciences called 'New Approaches in the Field of Biography'; papers given by Tiina Kinnunen, Maarit Leskelä-Kärki, Birgitte Possing, Benito Bisso Schmidt and Catherine Horel were debated with intense interest, as was the case, too, at the sessions of the International Federation for Research on Women's History at the Jinan conference. The conferences organized by the European Network on Theory and Practice of Biography, ETNB have documented the same intense interest for the theories and methods behind the biographical turn (http://www.valencia.edu/ retpb/index-en.html). 
In this respect, the relation between biography and the wide field of life writing is particularly pertinent. ${ }^{2}$ Should a boundary be maintained or should border-crossings be encouraged? We argue that historical scholarship can benfit from collaboration with the life writing studies in several respects. ${ }^{3}$ For instance, life writing studies contribute to an increasing understanding among historians of the specificity of diaries, letters, memoirs and auto-biographies as genres and how the self is produced in these writings. These so-called ego-documents have always been important sources for biographers as well as for historians. The latter have been used to regard these kinds of documents as useful primary sources and emphasised that they should be read as critically as other sources. So, traditionally they have been seen from the point of view of source criticism and, accordingly, their truth value has been tested with great skepticism, particularly in the case of memoirs and autobiographies. ${ }^{4}$

The chapters of this book show how the contribution of life writing studies is intrinsic for biographical research and writing. The authors use letters, diaries and memoirs, but also more marginal material such

2 The relation between these fields is under debate at the moment, see for instance Renders and de Haan (eds.) 2013, where they want to maintain, and even advance, the strict boundary between biography and life-writing. In their book, Renders and de Haan attacked the field of life writing and particularly the scholar and director of the Biography Center at the University of Manoa, Craig Howes. They argued that it is necessary to make a biographical turn, since life writing scholars had not been attentive enough to biography studies. Howes responds to the critique in the next book of Renders et al. (2016), and very convincingly argues for what life writing is, attempts to correct wrong facts and mistakes in their previous book, and aims at building bridges between these two fields. See Howes 2016. See also Rollyson 2013. From our perspective, there already are various bridges and interesting overlaps that have affected and developed the field of biographical research. Thus, it is hard to understand the perspective that Renders and de Haan seem to possess so defensively. Academic discussion is, however, valuable and our volume seeks to contribute to it.

3 On the definition of life-writing studies, see e.g. Caine 2010, 66; Smith and Watson 2010; Howes 2016. See also Oxford Centre for Life-Writing Studies 'What is life-writing', https://www.wolfson.ox.ac.uk/what-life-writing

${ }^{4}$ See e.g. Plummer 2001 and Stanley 2013. 
as portraits, novels, plays, and surveillance material in various productive ways. The chapters also remind us that a biographer must not take any material as self-evident, but contextualise it both in relation to the protagonist, and to his/her surroundings and time as well as to textual conventions. We must also acknowledge that different materials as well as different theoretical views upon them open up different perspectives to persons. Thus, today we know that an individual is never to be read, told or analysed as only one homogeneous entity, but rather as a human being with multiple selves. This book also demonstrates how historical biography can further develop not only the methodological tools of diverse autobiographical sources, but also more official or public sources. Historians can, for example, show the historicity of various autobiographical materials: a letter from the seventeenth century is a very different piece of historical material and textual object than a letter from the early twentieth century. ${ }^{5}$

A related issue is how biographical research relates to (other fields of) historiography. The history of this relation has been contested, and for several reasons. The ambivalent attitude that some women's and gender historians have had towards biography, an attitude influenced by social history, Marxism, structuralism and poststructuralism, can be partly explained by the traditional focus of biography on great men and, in some rare cases, on prominent women. This background raises an interesting question about the limits of democratisation in biographical research that is not confined to women's biographies only but is a more general one, as well as a related question about methodologies. Who is seen as worthy of a biography and if ordinary people are, how are their lives to be treated?

It has been argued that the recent and renewed interest in biography re-humanises history but does not necessarily democratise it. ${ }^{6}$ By democratisation we mean the notion that every human being has a unique, narratable history, and no life, as the Italian philosopher Adriana Cavarero has argued, follows 'in the footsteps of another life [-- nor leaves

5 On this discussion, see e.g. Leskelä-Kärki, Lahtinen, Vainio-Korhonen and Vehkalahti 2011.

${ }^{6}$ Possing 2015, 19, 61-62. 
behind the same story.' Ideally, biography should reflect upon this. And indeed there has in recent years been an increased interest among scholars to explore the lives of 'ordinary' people and their 'ordinariness', in particular as revealed (or performed) in private letters and diaries. These studies, which have been prominent in the Nordic countries, for instance Finland, Sweden and Iceland, have resulted in articles in journals and anthologies or monographs, some of which could rather be defined as microhistorical than biographical studies. ${ }^{8}$ Furthermore, some of these studies have resulted in collective or group biographies where the individual stories are both being narrated and used to illuminate bigger processes. 'We find this a promising way of treating ordinary people and their lives, a way to democratise history by using the biographical method. In this volume, the chapter written by Kaisa Vehkalahti explored how child welfare documents can be analysed as biographical documents, and how telling life-stories and producing knowledge for administrative purposes are intertwined.

Thus, the biographical landscape does seem to reflect not only gender but also class, ethnicity and the diverse identities of people in a more nuanced way than before. ${ }^{10}$ However, a full-length biography of a single individual is still characterised by the idea of greatness and worthiness. And if the protagonists' worthiness does not stem from exceptionality there is the claim of representativity, of mirroring the lives of others, of being "a window" to the past, of epitomising something bigger than just a life that was lived.

So, how to treat an ordinary life? How to contextualise it? How to represent it? As this book demonstrates there are many ways to write

7 Cavarero 2001, 2.

${ }^{8}$ See e.g. Edlund 2007; Liljewall 2007; Kuismin and Driscoll (eds.) 2013; Edlund and Haugen (eds.) 2014; Halldórsdóttir 2015.

${ }^{9}$ See e.g. Heini Hakosalo's group biographical project concerning the first women doctors in Finland, in e.g. Hakosalo 2014 and 2015, see also her chapter in this book. A recent example, with Nordic relation, is also Suzanne Rabow-Edling's book Married to the Empire. Three Governor's Wives in Russian America 1829-1864, where she relates the lives of three women who all were married to governors in Russian America (Alaska). She asks how they coped and how they adapted (or did not adapt) to life on the frontiers.

${ }^{10}$ See e.g. Caine 2010; Possing 2016, 49-60. 
a life and there are no simple answers to these questions. We can also ask whether a group biography or a pair biography would be a way of democratising the genre even more. We do acknowledge the importance of exploring and writing about diverse and ordinary lives of the past in their own right. These reflections are important because in problematising the object of biographical writing they also problematise the limits of biography itself and, furthermore, raise questions about the relationship between biography and, for instance, microhistory.

Relationality and ethics: biographers, protagonists and readers

One of the goals we set out for this book was to develop the concept of relationality. This can be seen in the individual chapters, but mainly concerning the relations between biographers and their protagonists or the overall idea of seeing identity as relational. There is another aspect to be pondered upon, namely the relation between the biographer and the audience, and the place of biography in the public discussions concerning history.

Scholars have theorised this precarious but important relationship. Fir instance, Philippe Lejeune discussed the relationship between the autobiographical author and the reader in his influential essay 'The autobiographical Pact'. Lejeune argued that there is a 'contract' between the author and the readers, who expect the autobiography to be authentic, referential. ${ }^{11}$ But then, biography, where the author and the protagonist are not the same person, is different. It does not, however, change the truth claim, as Paula Backscheider has argued in Reflections on Biography. The reader must believe that the biographer knows what he or she is talking about and tell it accurately, fairly, and with comprehension of related contexts.' ${ }^{12}$ In her recent book Ind i biografien/Understanding Biographies, Birgitte Possing brings the discussion on truth further by elaborating the complicated relationship of all three: the author, the pro-

${ }^{11}$ Lejeune 1989, 3-30.

12 Backscheider 2001, 10 
tagonist and the reader. It is the biographer who decides what 'reality' will be represented in the biography but this reality is inevitably shaped by all three: the expectations of the readers (the public), the sources/the voice of the subject/protagonist and the biographer's interpretation of these sources. ${ }^{13}$

A related question concerns the ethics of biographical writing. The question has become topical with the so-called ethical turn in the humanities. ${ }^{14}$ We underline how 'every biographer holds the fate of someone else in her hands. ${ }^{15}$ How do historians deal with this responsibility? These reflections about the biographer's responsibility towards the protagonist's integrity, on the one hand, and her/his scholarly search for historical truths, on the other hand, are not a novelty but have interested biographers for a long time. For instance, the Finnish historian Merja-Liisa Hinkkanen asked already in the 1990s whether biographers should take something like a degree that equips them to adequately handle human life. ${ }^{16}$ Since then, it seems, ethics and biography have been widely discussed in the field of biographical research.

\section{Biography and the transnational turn in history}

Our third point relates to one of the most topical issues in present historical scholarship, namely the deconstruction of methodological nationalism and the creation of transnational history. How does biographical research contribute to this challenge? For instance, collective national biographies are still compiled today and academic historians participate in this work. ${ }^{17}$ How should they negotiate this participation?

${ }^{13}$ Possing 2016, 113-119.

${ }^{14}$ See e.g. History and Theory 2004.

${ }^{15}$ Possing 2015 and 2016.

${ }^{16}$ Hinkkanen called for "pieteetti" (meticulousness) when dealing with past lives. See Hinkkanen 1995. See also Österberg 1996.

${ }^{17}$ See e.g. Dansk Kvindebiografisk Leksikon, vol. 1-4, 2001 and Svenskt kvinnobiografiskt lexikon, Swedish Women On-line (SWO) from the Middle Ages to the Present. A Biographical Dictionary of Swedish Women. http://historiskastudier.gu.se/forskning/svenskt-kvinnobiografiskt-lexikon 
According to Maria Grever, the historical culture of Western countries has evoked the fear of plurality in its tendency to maintain the icons and canons of national histories. ${ }^{18}$ In this process, one of the most fundamental images has been that of 'great men', often accompanied by a series of 'classical ideas' that canonised male individuals have embodied. In Finland, Irma Sulkunen's project on the contested history of the cult of Elias Lönnrot (compiler of the national epic Kalevala) responds to Grever's call for a deconstruction. In her project, Sulkunen aims at decoding methodological nationalism by critically exploring the close link between biographical narration and nation-building, a link that Michael Jonas has regarded as characteristic of the Finnish biographical tradition. ${ }^{19}$

The Nordic scholars involved in biographical research are highly aware of the fact that biography is critisised for telling too little about the wider world. Their response has been to write studies which emphasise the importance of contextual analysis. These empirical studies have employed topical methods and perspectives - from microhistory to the history of mentalities and to postmodern ideas - to narrate individual lives and, increasingly, the entangled lives of historical actors. ${ }^{20}$

Narrating entangled lives with transnational dimensions offers a way to go beyond the national scope and develop various innovative approaches. ${ }^{21}$ In Den röda grevinnan. En europeisk historia (2010) the Swedish historian Yvonne Hirdman not only narrates the transnational life of her mother who lived in different parts of Europe and moved across borders, but in doing so, depicts the political history of a whole continent in the twentieth century. ${ }^{22}$ In this book, Kristine Kjærsgaard wrote about the diplomat Bodil Begtrup, who developed her life and career on an international scene, and in several countries. One of the most recent examples of transnational history is provided by the cross-

\footnotetext{
${ }^{18}$ Grever 2009.

${ }^{19}$ Sulkunen 2009; Jonas 2009.

${ }^{20}$ Gabaccia and Maynes 2012; Smith 2010, 736-742; Zinsser 2013, 309-318.

${ }^{21}$ The concept of transnational is a debated and difficult one as it overlaps with many other concepts such as international, global, entangled histories (histoire croisée) etc. See e.g. Hunt 2015.

${ }^{22}$ Hirdman 2012.
} 
Nordic community of historians of missionary work. Their work is presented, for instance, in the themed issue of the Scandinavian Journal of History, entitled 'Mission, Relief and Development: Gender and Nordic Missions in Transnational and Humanitarian Settings, ca. 1890-1960'. The focus of the articles in this issue is not strictly biographical but they do open up a possibility of depicting transnational lives. We agree with the German historian Hannes Schweiger, who argues that the transnational perspective affects our understanding of the cultural identity of individuals. He points out that there is a need for research that crosses the national borders. The challenge does not concern only people who move across borders but also, for example, archives that are usually compiled for national purposes. ${ }^{23}$

Biography as a tool to combine micro and macro

At the moment, there are voices in the academic milieus that urge historians to give answers to big questions of human life and survival. These answers are associated with macro-level analysis. ${ }^{24}$ Biography has been connected with microhistory, which has been popular within historical scholarship for some time. Are the different fields drifting apart? Will we return to the time when structural history dominated and biography was neglected? If history is required to deal with 'big questions', based on large-scale materials (structures, digital methods), will biography become again the under-theorised step-child that is popular among readers but marginalised among professional historians?

We believe that there does not need to be a clear-cut division between the micro and the macro levels, between the more detailed and often nuanced stories of individuals and the big processes of history. In fact, our book, like the biographical turn itself, seeks, rather, to overcome the distinctions between micro and macro, private and public, and to show how they interact and overlap. Biography is a valid way to

${ }^{23}$ Schweiger 2012.

${ }^{24}$ Guldi and Armitage 2014. 
both study the most intimate spheres of life and to illuminate larger historical processes and their effects to human life. Biography, for instance a family biography, can also cover a long period of time. It is through the particular and the most intimate that we usually attach ourselves to history, place and space. Thus, writing history can never be only about looking at the bigger picture - the bigger picture makes sense only when we find particularities to attach ourselves to.

We are living in an era of globalization. For example, the recent refugee flow to Europe both from Africa and from Syria, Iraq, and Afghanistan demands our attention and calls for new ways of relating ourselves to this humanitarian crisis. There is even more need than before to hear the individual voices, both from the past and in the present.

We claim that biographical research and life-writing studies show how important it is to analyse things through individuals, individual experiences, small scale events on the micro level. In the future, new digital technologies and the so-called big data can offer new ways of combining the small and large scale histories. For instance, a project based at the University of Turku, Finland, is developing new digital tools for collecting and analysing asylum-seekers' stories. ${ }^{25}$ Individual, micro-level life-stories can be combined into large-scale digital databases that show the differences and similarities in peoples' individual situ-

25 The workshop 'Travelling stories in the shadow of forced migration' was organised in June 2016, and will continue as a research project. See more at: https://selmacentre.wordpress.com/. Similar digital projects have been launched in various contexts. For example, a website project Phenomenal people, where both the life-stories of famous women as well as ordinary women have been collected and published http://www.phenomenalpeople.org.uk/ Also the Facebook project Humans of New York has since 2010 grown from a small scale photography project into a life-writing project, where the photographer Brandon Stanton has travelled also outside New York, in Pakistan and Syria, to collect life-stories and share them on his blog and Facebook. His initial idea was to just take photographs of people in his home surroundings in New York, but gradually he began to write their stories and publish also small citations from them. This grew into a larger life-story project, which he began to thematise under different topics. Nowadays his site and Facebook has over twenty million followers, the project has produced books and has had a tremendous effect both for the lives of those who have told their stories and for those who follow and interact with the site. http://www. humansofnewyork.com/about 
ations, and give space for an understanding of both individual destinies and wider circumstances.

In his influential and praised autobiographical (or autofictive) novel series, Min kamp (2009-2011, in English translation My struggle in 2011-2016), the Norwegian Karl-Ove Knausgård shows in his distinctive way the power of the most intimate that connects us to other people. In the last part of the series, he devotes four hundred pages analysing Europe, Hitler and the Holocaust in order to understand how it all could happen - and what it means to us that it did. He speaks for the importance of the individual and life-stories instead of only seeing people from a (historical) distance, as mass of nameless bodies. In doing so, we find his argument valuing the role of both autobiography and biography in our culture. Knausgård argues that if we get closer to an individual, so close that we can hear his or her name when it is whispered, and look into his or her eyes where the soul is visible, as unique and irreplaceable, and hear the story of one ordinary day in this person's life, surrounded by his or her loved ones - it is then, when we are able to see the other individual, the one who is not as we are, but the precondition of ourselves. And it is "you". ${ }^{26}$ Thus, Knausgård highlights relationality,

${ }^{26}$ The last part of the series My Struggle has not yet been translated in English, thus we have relied on the translation in Finnish and the original text in Norwegian: 'Går vi imidlertid helt inntil, in mot hver enkelt av dem, så nær att vi kan høre navnet når det blir hvisket, og se in i øynene, hvor den enes sjel viser seg, uniko g umistelig, og hører fortellingen, om en dag i det menneskets liv, omgitt av sine nærmaste, sin familie og vennet, en vanlig dag på ett vanligt sted, med all sin glede og skrapelighet, misunnelse og nysgjerrighet, rutiner og spontanitet, fantasi og kjedsomhet, hat og kjærlighet, er det det motsatte some viser seg, den ene, ikke som jeg, men jeg-ets betingelse. Og det er du.' [citation in Finnish: 'Jos kuitenkin menemme lähemmäs, kohti jokaista yksittäistä ihmistä, niin lähelle, että kuulemme nimen kun se kuiskataan, ja katsomme silmiin joissa ihmisen sielu näyttäytyy, ainutlaatuisena ja erehtymättömänä, ja jos kuulemme kertomuksen yhdestä tuon ihmisen elämän päivästä, läheisistä, perheestä ja ystävistä, ihan tavallisesta päivästä jonka hän on viettänyt jossakin ihan tavallisessa paikassa, hänen iloistaan ja suruistaan, kateudestaan ja uteliaisuudestaan, rutiineistaan ja spontaanisuudestaan, mielikuvituksestaan ja ikävystymisestään, vihastaan ja rakkaudestaan, meille näyttäytyy vastakohta, yksilö, ei minä vaan minän ehto. Ja se on sinä.'] Knausgård 2011, 784 and Knausgård 2016, 854. 
our connectedness to each other that can be revealed through the stories. At its best, biography can show us the meaning of individual lifestories in this constantly changing world.

\section{Bibliography}

Backscheider, Paula: Reflections on Biography. Oxford University Press, Oxford 1999.

Cavarero, Adriana: Relating narratives. Storytelling and selfhood. First published in Italian 1997 Tu che mi guardi, tu che mi racconti. Transl. by Paul A. Kottman. Routledge, London, New York 2000.

Edlund, Ann-Catrine; Ashplant, Timothy G. and Kuismin, Anna (eds.): Reading and Writing from Below: Exploring the Margins of Modernity. Northern Studies Monographs 4. Vardagligt skriftbruk 4. Umeå University and the Royal Skyttean Society, Umeå 2016.

Gabaccia, Donna R. and Maynes, Mary Jo: Introduction: Gender History Across Epistemologies. Gender \& History. 24:3 (2012), 521-539.

Grever, Maria: Fear of plurality. Historical culture and historiographical canonization in Western Europe. Gendering Historiography. Beyond National Canons. Eds. Angelika Epple and Angelika Schaser. Campus, Frankfurt/Main 2009, 45-62.

Guldi, Jo and Armitage, David: The History Manifesto. Cambridge University Press, Cambridge 2014. http://historymanifesto.cambridge.org/

Hakosalo, Heini: 'Our Life Work': Professional Women and Christian Values in Early 20th-Century Finland. Between Ancestors and Angels: Finnish Women Making Religion. Eds. Terhi Utriainen and Päivi Salmesvuori. Palgrave Macmillan, New York 2014, 83-102.

Hakosalo, Heini: Elin och Ille. Syskon, kön och medicinsk karriär i det tidiga 1900-talets Finland. Historisk Tidskrift för Finland 2/2015, 125-160.

Hinkkanen, Merja-Liisa: Oman elämänsä sankaritar? Elämäkerrallisen tutkimuksen ongelmia. Työkalut riviin. Näkökulmia yleisen historian tutkimusmenetelmiin. Ed. Eero Kuparinen. Turun yliopiston historian laitos, julkaisuja 43, Turku 1997.

Hunt, Lynn Hunt: Global History. Transnational Lives - Biographies of Global Modernity, 1700-present. Eds. Deacon, D., Russell, P., Woollacott. Palgrave MacMillan, UK 2010.

Hunt, Lynn: Writing History in the Global Era. W. W. Norton \& Company, Inc., New York 2014.

History and Theory. Historians and ethics thematic issue. 43 December (2004).

Howes, Craig: What are we turning from? Research and ideology in biography and Life Writing. Biographical Turn: Lives in history. Eds. Hans Renders, Binne de Haan and Jonne Harmsma. Routledge, London 2016, 165-175.

Janz, Oliver and Schönpflug, Daniel (eds.): Gender History in a Transnational Perspective. Biographies, networks, gender orders. Berghahn Books, New York \& Oxford 2014.

Jonas, Michael: Skandinavische Biographik. Handbuch Biographie. Methoden, Traditionen, Theorien. Ed. Christian Klein. Verlag J.B. Metzler. Stuttgart 2009, 307-312.

Knausgår, Karl-Ove: Min Kamp 6. Oktober, Oslo 2011.

Knausgård, Karl-Ove: Taisteluni 6. Translated by Katriina Huttunen. Orig. Min Kamp 6. Like, Helsinki 2016.

Kuismin, Anna and Driscoll, M.J. (eds.): White Field, Black Seeds. Nordic Literacy Practices in the Long Nineteenth Century. SKS, Helsinki 2013.

Lejenue, Philippe: On Autobiograpy. Edited and with a foreword by Paul John Eakin. Translated by Katherine Learly. University of Minnesota Press, Minneapolis 1989. 
Leskelä-Kärki, Maarit; Lahtinen, Anu; Vainio-Korhonen, Kirsi; Vehkalahti, Kaisa: Kirjeiden uusi tuleminen. Kirjeet ja historiantutkimus. Eds. Anu Lahtinen, Maarit Leskelä-Kärki and Kirsi Vainio-Korhonen. SKS, Helsinki 2011, 9-27.

Liljewall, Britt:'Ack om du vore här.'1800-talets folkliga brevkultur. Nordiska museets förlag, Stockholm 2007.

Possing, Birgitte: Ind i Biografien. Gyldendal, Copenhagen 2015.

Possing, Birgitte: The Historical Biography. The International Encyclopedia of Social and Behavioral Sciences. Elsevier, Oxford 2001, 2013-2017.

Possing, Birgitte: Understanding Biographies. On Biographies in History and Stories in Biography. The Southern University Press, Odense 2016.

Rabow-Edling, Suzanne: Married to the Empire. Three Governor's Wives in Russian America 1829-1864. University of Alaska Press, Fairbanks 2015.

Renders, Hand and de Haan, Binne (eds.): Theoretical Discussions of Biography, Approaches from History, Microhistory, and Life Writing. Edwin Mellen Press, Lewiston, Queenston, Lampeter 2013.

Renders, Hans; Haan, Binne de and Harmsma, Jonne (eds.): The Biographical Turn: Lives in History. Routledge 2016.

Rollyson, Carl: Theoretical discussion of biography: Approaches from history, microhistory and biography. Life Writing 36:2 (2013), 392-395.

Plummer, Ken: Documents of Life 2. An Invitation to a Critical Humanism. Second Edition. Sage Publishing, London 2001.

Schweiger, Hannes: Global Subjects: The Transnationalisation of Biography. Writing Between the Lives: Life Writing and the Work of Mediation. Life Writing. 9:3 (2012), 249-258.

Smith, Bonnie G.: Women's History: A Retrospective from the United States. Signs: Journal of Women in Culture and Society. 35:3 (2010), 723-747.

Stanley, Liz (ed.): Documents of Life Revisited. Narrative and Biographical Methodology for a 21st Century Critical Humanism. Routledge, 2013.

Sulkunen, Irma: Biography, Gender and the Deconstruction of a National Canon. Gendering Historiography. Beyond National Canons. Eds. Angelika Epple and Angelika Schaser. Campus, Frankfurt/Main 2009a, 65-77.

Zinsser, Judith P.: Women's and Men's World History? Not Yet. Journal of Women's History. 25:4 (2012), 309-318. 


\section{Acknowledgements}

The process of writing this book has been a long one. We would at this point want to thank those who have in many ways been part of this project. First of all, all the authors, who have put so much time and effort for their chapters during the long process of doing the book. Over the years, we have met at conferences and seminars and the outcome of those discussions are now present in the book. We want to thank the organisers at these conferences who have hosted our sessions, panels and roundtables on life-writing and biography: the Nordic women's and gender history conferences in Reykjavik 2008, Bergen 2012 and Stockholm 2015, ISCH Annual conference in Turku 2010, IABAEurope conference in Tallinn 2011, the co-operation with the European Network for the Theory of Biography in Oxford and Valencia, and the World History Congress in Jinan, China 2015. We also want to thank The School of History, Culture and Arts at the University of Turku and Danish National Archives in Copenhagen for supporting our editorial meetings in 2014.

We want to thank warmly the $\mathrm{k} \& \mathrm{~h}$-publisher for publishing this book in the cultural history - kulttuurihistoria -series, and particularly the series editors, cultural historians Jukka Sarjala, Niina Lehmusjärvi and Riitta Laitinen for their help during the editorial process. Warmest thanks to the anonymous referees who read the whole manuscript and gave valuable comments as well as to those who have worked with language editing, particularly Jennifer Saalinki. Thanks for the patient and efficient work with the layout to Kimi Kärki as well as to Karoliina Sjö for helping us to make the index. 
During the book project also a new research centre was established at the University of Turku. SELMA: Centre for the Study of Storytelling, Experientiality, and Memory has supported this project and particularly the launching event. 


\section{Authors}

Andersson, Irene works as an Associate Professor, Malmö University, Sweden. Her biographical research interest concerns women's active resistance in social movements. In the article 'Ett envist engagemang. Elin Wägner som fredsaktivist' (Rummet vidgas. Kvinnors väg ut $i$ offentligheten 1880-1940, 2002) the author Elin Wägner is studied as a peace activist in debates, actions and organizations instead of as a fiction writer.

Carlsson Wetterberg, Christina is Professor Emerita of History at Örebro University, Sweden. She has published several books and articles on the women's movement, social welfare and family law, and lately within the area of biographical research. Among publications related to biography are 'Att biografera en kvinnlig intellektuell' (Med livet som insats, 2007) and 'Bara ett öfverskott af lif'. En biografi om Frida Stéenhof (2010). She is currently working on a biography on Anna Bugge Wicksell, an important figure within the Swedish suffrage and peace movements and a member of the general assembly of the League of Nations.

Halldórsdóttir, Erla Hulda, PhD, works as a Senior Lecturer in Women's and Gender History, University of Iceland. Her research field is women's history, biography, correspondence and historical literacy. Among her published work in Icelandic is the monograph Nutimans konur (2011) [Women of Modernity. Women's Education and the Construction of Gender in Iceland 1850-1903]. Among recent works in 
English is: 'Do Not Let Anyone See This Ugly Scrawling': Literacy Practices and the Women's Household at Hallfreðarstaðir 1817-1829' (Life Writing, 2015). Halldórsdóttir is currently working on the biography of Sigríður Pálsdóttir and a project on women, suffrage and agency in the 20 th century Iceland.

Hakosalo, Heini, PhD, Adjunct Professor, is a Senior Lecturer in History of Science and Ideas at the University of Oulu, Finland. She specialises in history of medicine and health. She has published, for instance, on late nineteenth century brain science, on the first generations of medical women in Finland and Sweden and on tuberculosis in the twentieth century Finland. Her methodological papers discuss the use of the Foucauldian notion of 'micromechanism of power' in the study of academic institutions, on the historical study of medical concepts and on biographical research. Her biographical articles include 'Elin och Ille. Syskon, kön och medicinsk karriär i det tidiga 1900talets Finland' (2015), 'Modest witness to modernization: Finland meets Ovamboland in mission doctor Selma Rainio's family letters, 1921-32' (2015), "Our Life Work": Professional Women and Christian Values in Early 20th-Century Finland' (2014). She has coedited a book on historical biography (Historiallinen elämä. Biografia ja historiantutkimus 2014) and is working on a book on the first generations of Finnish and Swedish medical women.

Harmainen Antti, MA, is a Doctoral Student at History School of Social Sciences and Humanities at the University of Tampere, Finland. Harmainen is currently finalising his thesis concerning modern western esotericism and its ideological implications among the Finnish intelligentsia in 1880-1910. Harmainen has published articles on manhood, nationalism and religion, esotericism and biographical approaches.

Kinnunen, Tiina is a Professor in Finnish and Northern European History at the University of Oulu, Finland. She has published books and articles on the history of European feminism, history of historiography and cultural history of war. Among publications related to biography are articles "'Mainioita naisia" - pienoiselämäkerrat autonomian ajan 
historiapolitiikassa' (Historiallinen Aikakauskirja 4/2012) and "'Taistelevat sisaret" - kaksoiselämäkerta Ellen Keystä ja Alexandra Gripenbergistä eurooppalaisina feministeinä' in Historiallinen elämä - biografia ja historiantutkimus (2014). She is currently working on a comparative biography of Ellen Key and Alexandra Gripenberg, two European feminists, the aim of which is to combine biographical research with transnational historiography and memory studies.

Kjærsgaard, Kristine is an Associate Professor at the Department of History, University of Southern Denmark, Denmark. Her research area is Scandinavian foreign policy with an emphasis on the United Nations, human rights and development aid. In addition to these research areas comes an interest in biography. This interest has resulted in a number of articles, the most recent one 'The reluctant public diplomacy entrepreneur: Danish ambassador Bodil Begtrup in Iceland, Switzerland and Portugal, 1949-73' (Histories of Public Diplomacy and Nation Branding in the Nordic and Baltic Countries. Representing the Periphery, eds. Nikolas Glover, Louis Clerc and Paul Gordon, Brill 2015).

Leskelä-Kärki, Maarit, $\mathrm{PhD}$, Adjunct Professor, is a Senior Lecturer at the Department of Cultural History and Vice-Director of SELMA: Centre for the Study of Storytelling, Experientiality, and Memory at the University of Turku. She has published widely in the area of cultural history of writing; history, ethics and theory of biographical research as well as methodologies of autobiographical sources. She is the author of, for example, Kirjoittaen maailmassa. Krohnin sisaret ja kirjallinen elämä. [Lives in Writing: the Literary Krohn Sisters 2006] and co-author of Kirjeet ja historiantutkimus [Letters and Historical Research, 2011]. Her most recent international articles in the area of biographical research include 'Close and distant. On relationality in biographical research' (La historia biográfica en Europa: Nuevas perspectivas, 2015) and 'Histories of women, histories of nation: Biographical writing as women's tradition in Finland, 1880s-1920s' (Women telling nations, 2014). At the moment, she is finishing an essay book on the practices of biographical research and is working on a biographical study on Minna Krohn. 
Possing, Birgitte is a Professor of Comparative Cultural Studies at The National Archives in Denmark. She has published several biographies, books and articles on gender issues, women's history, and the methodology of biographies. Her most recent articles related to biography include 'The Historical Biography' (The International Encyclopedia of Social and Behavioral Sciences, 2001 and 2015); 'The Biographer's Power and Private Archives' (Crisis, Credibility and Corporate History, 2014). Her most important biographical books are Viljens Styrke. En Biografi om Natalie Zable (1992 \&1997), Uden Omsvøb. Et portrat af Bodil Koch (2007) and Ind i biografien (2015, translated to English in 2016 Understanding Biographies. On Biographies in History and Stories in Biography).

Vehkalahti, Kaisa, PhD, Adjunct Professor in Cultural and Social History, works as a Research Manager at the Finnish Youth Research Society. She is the author of Constructing Reformatory Identity. Girls' Reform School Education in Finland, 1893-1923 (Peter Lang, 2009) as well as other publications on the history of childhood and youth, girlhood studies, research ethics and the cultural history of writing. Her chapter is linked to her postdoctoral research project about policing youth in post-war Finland, 1945-1969, funded by the Academy of Finland. 


\section{Index}

A

Ahlbeck, Jutta 234

Ambjörnsson, Ronny 148, 169

Andersson, Irene 24

Arendt, Hannah 48

Asp, Gustaf 111-116

Asp, Hilda 111-116

Asp, Maria 114

Austen, Jane 211

B

Backscheider, Paula R. 85-87, 91, 256

Balfour, Arthur 54

Beauvoir, Simone de 44, 63, 168

Begtrup, Bodil 21, 121-135, 137, 138, 258

Bennedsen, Dorte 44

Bertram, Boris B. 45

Bjarnhéðinsdóttir, Bríet 92

Björnsdóttir, Guðrún 90

Bobrikov, Nikolai 156

Bolt-Jørgensen, Laurits Bolt 21, 122-135, 137, 138

Bonheur, Rosa 203, 204

Bosch, Mineke 17, 227

Bourdieu, Pierre 48
Boydston, Jeanne 17, 116-118

Brandes, Georg 71

Bremer, Fredrika 144

Brink Pinto, Andrés 170

Brockmeier, Jens 203

Butler, Judith 68

C

Caine, Barbara 18, 21, 22, 86, 87, 92-94, 101, 103, 104, 107, 220, 248

Canth, Minna 110

Cantor, Georg 212

Carlsson Wetterberg, Christina 12,20

Cavarero, Adriana 27, 84, 96, 188, 191, 192, 254

Cederskiöld, Maria 154, 159

Christian IX, King of Denmark 95

Connell, Raewyn 107

Cooper Jr., John Milton 146, 150, 159

D

Darwin, Charles 114 
Davis, Kathy 12, 13

Durand, Marguerite 67, 68

E

Elmgren, Elin 220

Elmgren, Robert 220

Englund, Boel 205

Enke, Anne 169

Erkko, Eero 110-116

Erkko, Elias Rudolf 110-116

Erkko, Johan Henrik 108-116

Eskelin, Karolina 222

F

Farrar, Frederick 114

Florin, Christina 27, 117, 224, 227

Foucault, Michel 235

Fries, Ellen 144, 156, 158, 159

Fry, Roger 94

Furuhjelm, Annie 158

G

Garpe, Margareta 177

Ginzburg, Carlo 64, 246, 247

Goffman, Erving 124, 125, 138

Granfelt, Mandi 24, 149

Granqvist, Hilma 219, 226

Grever, Maria 106, 258

Gripenberg, Alexandra 24, 143-162

Guðmundsson, Páll 81

$\mathrm{H}$

Haavet, Inger Elisabet 22

Hacking, Ian 234

Hakosalo, Heini 27, 28

Halldórsdóttir, Erla Hulda 16, 19, 150

Hamilton, Nigel 10

Hansen, Arvid G. 165, 173, 174, 176

Harmainen, Antti 20, 28, 161
Harrikari, Timo 243

von Hartmann, Eduard 110, 114

Héðinsdóttir, Bríet 92

Hedtoft, Hans 135

Heikinheimo, Helmi 224

Heilbrun, Carolyn 86

Helgason, Porsteinn 81, 82

Hermansson, C.H. 175, 176

Herodotus 54

Hierta-Retzius, Anna 145, 159

Hinkkanen, Merja-Liisa 257

Hirdman, Charlotte 23

Hirdman, Yvonne 22, 23, 122, 123, 137, 258

Hitler, Adolf 261

J

Johnson, Louise C. 170

Jonas, Michael 14, 258

Jónsdóttir, Guðbjörg 90

K

Kallas, Aino (see Krohn, Aino)

Kallas, Oskar 190

Kapuscinski, Ryszard 54

Kares, Olavi 107

Katerma, Pia 202

Kauffmann, Henrik 130, 131

Keats-Rohan, Katharine 101

Kessler-Harris, Alice 87, 88, 150

Key, Ellen 24, 73, 143-162

Kinnunen, Tiina 24

Kjær, Kirsten 37, 53, 56

Kjærsgaard, Kristine 21, 28, 258

Klumpke, Anna 203, 204

Knausgård, Karl-Ove 261, 262

Koch, Bodil 11, 12, 20, 37, 38, 40-49, 51-56, 58, 188

Koch, Hal 42, 45-47, 55, 56

Koch, Jens 42, 45 
Kock, Karin 20

Kollontay, Alexandra 177, 179

Kotila, Pirkko 171

Kristmundsdóttir, Sigríður Dúna 92

Krohn, Aino 190, 191, 193-195, 206

Krohn, Aune 190, 191, 197-201

Krohn, Emma 190

Krohn, Helmi 190, 191, 194-197, 201

Krohn, Ilmari 190

Krohn, Julius 188, 190, 193, 195, 202

Krohn, Kaarle 190, 200

Krohn, Minna 27, 188, 190-195, 197-206

Kuusinen, Hertta 171

L

Laboulaye, Edouard 110

Lagerborg, Viva 224

Larsson, Lisbeth 62

Lárusdóttir, Elínborg 91

Laslett, Barbara 168

Lassila, Pertti 193

Lee, Hermione 21, 25, 96

Leidenius, Laimi 224

Lejeune, Philippe 256

Lepore, Jill 23

Leskelä-Kärki, Maarit 27, 105

Levi, Giovanni 10, 54

Lindgreen, Malin 48

Lindroos, Maria Wilhelmiina (see Krohn, Minna)

Luther, Martin 107

Lyons, Martyn 84, 97

Løgstrup, K.E. 55

Lönnrot, Elias 258
M

Magnússon, Árni 135

Malchau, Susanne 22, 27

Margadant, Jo Burr 62, 68

Maynes, Mary Jo 168

Merton, Robert 218

Moi, Toril 44, 63, 168

Morley, Rachel 25, 205

Munch, P. 132

Myrdal, Alva 123

Myrdal, Gunnar 123, 137

$\mathrm{N}$

Nietzsche, Friedrich 159

Niskanen, Kirsti 20

Nordau, Max 110

O

Ollila, Anne 17, 22

Osten, Suzanne 177

P

Pálsdóttir, Sigríður 19, 81-84, 89, 92, 94-97

Pálsdóttir, Sigrún 95

Pálsson, Páll 82

Pétursdóttir, Póra 95, 96

Pierce, Jennifer L. 168

Piispanen, Eva 224

Plummer, Ken 168

Possing, Birgitte 11-13, 15, 18, 20, 22, 122-124, 148, 188, 205, 256

$\mathrm{R}$

Rafeek, Neil 171

Rainio, Selma 224

Riviere, Joan 67, 68

Roberts, Mary Louise 67, 68

Rollyson, Carl 97

Roosevelt, Eleanor 121 
Runeberg, Fredrika 144

$S$

Saïd, Edward 51

Sana, Elina 216

Satka, Mirja 235

Scavenius, Erik 132

Schjerfbeck, Helene 202

Schweiger, Hannes 259

Seppänen, Anni 228

Setälä, Helmi (see Krohn, Helmi)

Shapin, Steven 218

Sigurðardóttir, Aðalbjörg 91

Sillanpää, Miina 23, 149

Smith, Sidonie 192

Spencer, Herbert 159

Spinoza, Baruch 159

Stanley, Liz 26, 168

Stanton, Elizabeth Cady 144

Steedman, Carolyn 233

Steénhoff, Frida 12, 61, 64-75

Stenbäck, Ottilie 198

Sulkunen, Irma 12, 17, 22-24, 26, $149,150,258$

Svenningsen, Nils 131

Svensson, Birgitta 234

Svensson, Valborg 24, 165-177, 180-182

Sörlin, Sverker 169

$\mathrm{T}$

Tamboukou, Maria 203, 204

Thackray, Arnold 218

Thorarensen, Sigurður G. 81

Porláksson, Björg C. 92, 93

Thoroddsen, Porvaldur 95

Porsteinsson, Björn 15

Toikko, Timo 235

Topelius, Zacharias 203

Treitel, Corinna 114
Tuohela, Kirsi 201

Tuulio, Tyyni 25, 147, 198

U

Uino, Ari 16

Ulvros, Eva-Helen 204, 205

$\mathrm{V}$

Vehkalahti, Kaisa 28, 255

Vuorela, Ulla 226

W

Ware, Susan 85, 88, 92

Watson, Julia 192

White, Hayden 75

Wiik, Hilda 202

Wiik, Maria 188, 201-204

Wikander, Anna 224

Woolf, Virginia 14, 21, 94, 187

Wägner, Elin 47

Y

Yrjö-Koskinen, Ida 158

Z

Zahle, Natalie 11, 15, 41, 42, 44, 53, $54,58,122$

Ö

Östberg, Kjell 170 